LINIYERSIDALE ['E SZO PAIJLU

INSTITUTO LE PSICOLUGIA

CURSO DE PÓS-GRADUACZO EM PSICULUGIA

"CORPO E DEFICIÉNCIA: ESPACOS DO DESEJO - REFLEXÕES SOB(RE) A PERSPECTIVA FEMININA. "

Candidata. ANA RITA LE PAULA

Orientadora: Profa. Titular Sylvia Leser de Mello

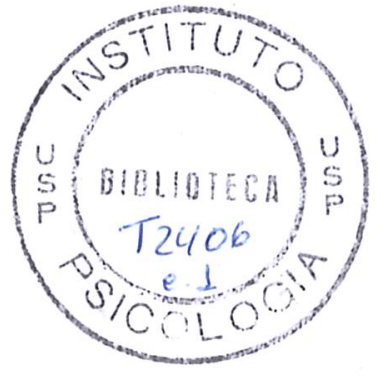

Vissertacão apresentada ao Instituto de Psicologia, Universidade de São Paulo, como parte dos requisitos para obtencão do grau de Mestre em Psicologia - área de concentracão P'SICULOGIA SOCIAL.

COMISSÃO JULGADURA

Profa. Dra. Tânia Maria josé Aiello Tofolo_taceie Ta fólo Prof. Dr. João Augusto Frayze-Pereira Nonfen-Profa. Titular Sylvia Leser de Mello

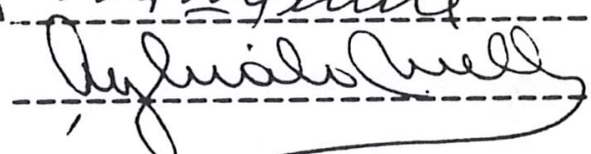

Defesa -1993 


\section{CORPO E DEFICIÊNCIA: ESPAÇOS DO DESEJO Reflexões Sob(re) a Perspectiva Feminina}

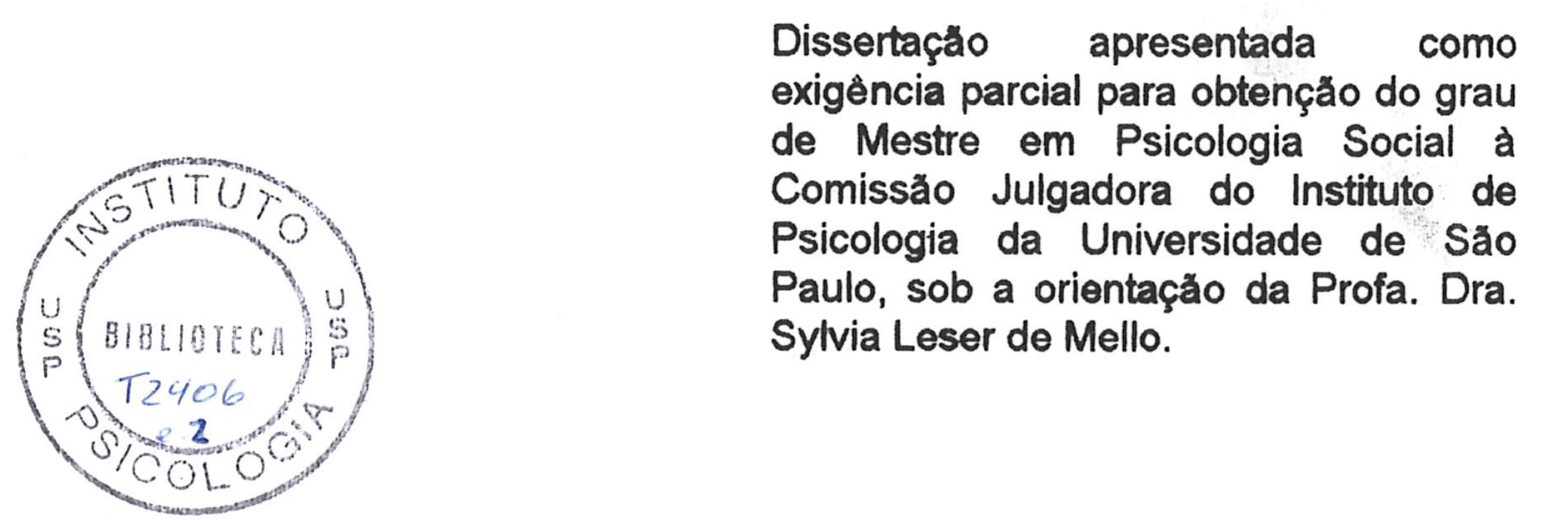

\section{UNIVERSIDADE DE SÃO PAULO \\ São Paulo - SP}


Aos homens e mulheres que pela presença em minha vida revelaram-me feminina.

Em especial, a minha mae, meu principio...

A Araci, por saber ser sempre absoluta e, simplesmente, amiga. 


\section{AGRADECIMENTOS}

Foram muitos os que contribuíram para a concretização deste trabalho ao longo do tempo, quer com um auxílio direto, quer pelo propiciar das condições mais favoráveis à sua elaboração. Quero externar aqui meus agradecimentos especiais:

À minha mãe, pelo carinhoso apoio sempre entusiasmado.

A meu pai, pelo respeito e atenção demonstrados a tudo que realizo.

Ao meu irmão Fernando, pela presença firme e afetuosa.

À Lourdes, Oswaldo, Magda e todos aqueles que, com seu trabalho, garantem que meu cotidiano transcorra bem, torcendo, eu sei, por mim.

À minha prima Cecília que foi meu primeiro modelo de "pesquisadora".

A meus amigos e colegas de trabalho que paciente e gentilmente souberam me compreender e aceitar os muitos momentos em que meus pensamentos voltavam-se para a dissertação.

Aos sujeitos entrevistados que, com generosidade, contaram suas vidas, expondo corajosamente suas fragilidades, medos, sonhos e desejos, imprimindo a este texto o que ele tem de mais vital.

À Rosana e Soraia pelo difícil e paciente trabalho de transcrição das entrevistas.

À Lia, pela amizade incondicional que sempre me dedicou.

e ansiedades.

À Cila, pela digitação, diagramação e, também, pela paciência com meus atrasos

À Tânia Tofolo que é e continuará sendo minha professora para além do âmbito da Universidade.

Ao Prof. João Frayze que recebeu com muita consideração as primeiras notas deste trabalho, tornando-se grandemente responsável pelo seu prosseguimento. 
À Profa. Sylvia Leser, pela extrema competência, dedicação e gentileza com que me orientou no processo de elaboração da dissertação, mas, fundamentalmente, pelo extremo apoio a mim dedicado, apesar de minha indisciplina.

À Araci que é e sempre foi uma interlocutora generosamente instigante e a quem devo o início de muitas idéias e o desenvolvimento consistente de outras tantas, além da afetuosa presença em diferentes espaços da minha vida. 
PAULA, Ana Rita de. Corpo e Deficiência: Espacos do Deseio Reflexões Sob(re) a Perspectiva Feminina. São Paulo. 1993. 184p. Dissertação (Mestrado). Instituto de Psicologia da Universidade de São Paulo.

Para além das visões estritamente clínicas, organicistas ou funcionais e, mesmo, masculinas, este estudo busca compreender a inter-relação dos significados sociais e individuais da deficiência e, particularmente, da articulação entre as representações sociais de mulher e de deficiente.

Para tanto, procedeu-se à análise do conceito de deficiência nas diversas práticas sociais e em diferentes abordagens psicológicas. Foram colhidas, ainda, histórias de vida de homens e mulheres com deficiência tísica visando à compreensão de como deficiência, sexualidade, condições sociais e outras características se articulam entre si e com os demais aspectos do contexto de vida destes sujeitos concretos.

A partir dos relatos dos entrevistados, percebeu-se que a deficiência é significada como ruptura da integralidade do corpo, gerando bloqueios no fluxo da própria história e um distanciamento dos espaços do mundo.

Quanto às possíveis relações entre feminilidade e deficiência, pode-se afirmar que estas dependem da perspectiva de análise adotada. Assim, neste estudo, surgiram relações de sobredeterminação de papéis sociais desvalorizados, contradição em termos dos afetos vinculados a estas condições e mesmo a simultaneidade de sentidos diversos, até opostos, a nível da vida intrapsíquica dos sujeitos.

Acredita-se que o caminho para a realização pessoal dos indivíduos com deficiência é a ampliação da capacidade de se auto-representarem de diferentes maneiras em um todo articulado, pelo desvelamento destes sentidos. 
PAULA, Ana Rita de. Corpo e Deficiência: Espacos do Deseio Reflexões Sob(re) a Perspectiva Feminina. São Paulo. 1993. 184p. Dissertação (Mestrado). Instituto de Psicologia da Universidade de São Paulo.

Over and above the strictly functional organic or clinic and even male views, this work looks for undestanding of the disability in the individual and social meaning interrelationship and, mainly, the woman and deficient social representations articulation interrelationship.

Thus, we conducted analysis on deficiency concept in various social practices and on different psychological approaches. Disabled women and men life histories were selected in order to provide understanding on how disability, sexuality, social conditions and other characteristics are linked among themselves and with the other aspects of these persons' life contexts.

From the report of the interviewed we noted that the disability is significative as a rupture of the body integrality generating obstructions in their history flow and a retirement from the world spaces.

About possible relations between deficiency and femininity, we can asseverate that they depend on the adopted analysis perspectives. So, it appears in this work overdetermination, relationship of undervalued social roles, contradiction about friendship that are linked to these conditions and even the simultaniety of different senses, even antagonistic, at these persons intrapsychic life level.

We believe that the way for personal realization for handicaped is the enlargement of their capacity of self-representation in different ways within an articulated entirety through disclosing these senses. 
SUMÁRIO

1 APRESENTAÇÃO

2 DEFICIÊECLA NA LITERATURA: EM BUSCA DE UMA OUTRA LEITURA 14

2.1 INTRODUÇÃO

2.2 METODOLOGLA

2.3 PRESSUPOSTOS TEÓRICOS

3 HISTÓRIAS DE VIDA

3.1 IMAGEM: A RECONCEITUAÇÃO MERCADOLÓGICA A História de Robson

3.2 ESTAGNAÇÃO: A IMOBILIDADE DO DESEJO A História de Márcio

3.3 SUSPENSÃO DA HISTÓRIA: A RECONSTRUÇÃO DO CORPO

A História de Edna

3.4 MORTE E FRAGMENTAÇÃO: A REVTTALIZAÇÃO PELO FEMININO

A História de Nina

3.5 ALIENAÇÃO: AS DIVERSAS FACES DO FEMININO

A História de Tina

4 EXPRESSAOO DA DEFICIENNCIA

4.1 A INSCRIÇÃO NO RITMO DA VIDA: TEMPO MOVIMENTO E DESEJO

4.2 A RUPTURA DA INTEGRALIDADE DO CORPO

4.3 ESPESSURA E DENSIDADE NOS ESPAÇOS SOCLAIS

5 ENTRE O FEMININO E A DEFICIÊNCIA: APROXIMAÇÕES

6 DA CONCLUSÃO COMO CONVTTE AO (RE)INICIO

7 REFERÊNCIAS BIBLIOGRÁFICAS

8 ANEXO 
Ver o conhecido com olhos de estrangeiro náo $e^{\prime}$ um exercicio incomum na filosofia; mesmo nas ciências vale a pena experimenta-lo de quando em quando, para relembrar o essencial.

Fábio Herrmann 


\section{1}

APRESENTAÇÃO

Para que o leitor pudesse ter uma compreensão além das discussões teóricas apresentadas neste trabalho, seria necessário falar de todas as dúvidas, das idas e vindas, das paradas, de como e por que foram escolhidos estes ou aqueles caminhos.

$\mathrm{Na}$ impossibilidade de contar todos os pormenores, optei por comentar determinados aspectos que me pareceram mais relevantes para que se tivesse uma visão dos "andaimes" dessa construção, usando-os até mesmo para explicar as razões de algumas das inúmeras falhas que o texto, por certo, contém.

Uma delas refere-se à questão de que este trabalho foi realizado ao longo de sete anos e em meio a uma rotina diária de demandas de tarefas diferentes, tais como as de dona-decasa e de profissional na área de reabilitação. Por minha própria natureza, do investimento em atividades práticas e a idéia, às vezes equivocada e ilusória, de que tais trabalhos pudessem concretizar antigos ideais de transformação da realidade, exerceram sobre mim um fascínio maior, se comparado ao empenho exigido pelo Mestrado, restando-me menos tempo do que desejaria para a leitura e a reflexão mais sistemática.

Que difícil, delicada e complexa é esta relação entre a imersão na prática cotidiana e o distanciamento necessário e disponibilidade para a reflexão crítica! 
Se por um lado foi limitadora, por outro, sem dúvida, foi esta prática que me possibilitou estar próxima da vida e do cotidiano de muitas pessoas, em especial, de mulheres deficientes que, embora não fossem sujeitos desta pesquisa, estavam e estão presentes, mediatizadas pelo que em mim ficou de suas experiências vitais. Isto me faz pensar quão equivocada é a idéia de que fazer uma dissertação é uma tarefa solitária. Pelo menos, para mim, foi uma experiência coletiva, ainda que sua dimensão grupal não seja tão direta à primeira vista.

Além das pessoas que contribuíram explicita e concretamente para a realização desta dissertação, desde minha orientadora, os sujeitos entrevistados, até a digitadora e outros a quem serei eternamente grata, houve outras pessoas a quem, por exemplo, em conversas informais, eu contava sobre determinada questão que me impedia de seguir adiante. Não raro, elas me forneciam, muitas vezes, até sem o saberem, a pista que me recolocava novamente no caminho. Sem falar na atitude de incentivo e apoio de tantos amigos nos momentos (e foram muitos) em que pensei em desistir.

Desta forma, é possível e mesmo provável que idéias ou fragmentos de idéias de muitas outras pessoas estejam aqui registrados, sem que haja possibilidade de se identificar precisamente quais e quais as fontes, uma vez que tais idéias se incorporaram em mim neste processo diário de diálogo com o mundo.

Assim, desde a sua elaboração primeira deste texto, já é de muitos autores e será refeito a cada leitura realizada. Não pretendi realizar uma abordagem exaustiva sobre o assunto, mesmo porque os discursos dos sujeitos são muito mais ricos do que aquilo que pode ser apreendido em um trabalho único de interpretação. Por isso, os caminhos da interpretação que fiz foram somente sinalizados permitindo ao leitor enveredar na leitura com o pensamento livre. Desta forma, seus autores iniciais serão multiplicados ainda mais.

A participação das pessoas entrevistadas foi especialmente importante, não só para mim, como também para o trabalho. Pois os encontros foram, de forma lenta, gradual e sistemática, produzindo transformações em mim certamente e no outro também, creio, desenrolando-se um processo semelhante ao ocorrido com Sherazade e o Califa na história das 
Mil e Uma Noites. As "Sherazades" entrevistadas contaram a mim, Califa atento e encantado, suas histórias de maneira extremamente hábil. E tal como Sherazade fez com o Califa, depois de certo tempo, as mulheres (e mesmo os homens entrevistados), contaram-me minha própria história, revelando e ampliando minha compreensão sobre a condição de mulher deficiente, reatando meus laços com a experiência feminina.

E a neutralidade "necessária" do pesquisador? Bem, esta teve de ser "substituída" pelo trabalho diligente, que tentei realizar, de deixar claro sob que perspectiva me coloquei e, portanto, possibilitou ou limitou o meu olhar. Se consegui totalmente, não sei. Porém tenho consciência de que produzi alguma transformação no outro e de que esta foi produzida em mim.

Eu imaginava, arrogantemente, confesso, que para fazer uma Dissertação sobre um tema ligado à deficiência, tratava-se apenas de comunicar por escrito aquilo que eu já sabia, dado que trabalho e vivo com a questão dioturnamente. (Logicamente, nunca menosprezei a dimensão desta tarefa, até porque escrever não é uma atividade que realizo sem esforços.) Mas não foi exatamente assim que ocorreu.

Certa vez, em uma das reuniões de supervisão do trabalho, minha orientadora falou-me, de certo para me tranquilizar, que um dos objetivos do mestrado é fornecer uma oportunidade, um primeiro exercício para o orientando aprender a fazer pesquisa.

Não sei se não falhei, em parte, na tarefa que julgava caber-me, ou seja, comunicar com clareza e explicar uma idéia, nem sei se aprendi a fazer pesquisa, porém, tenho certeza de que aprendi um de seus fundamentos: não há um conhecimento pronto, acabado, nem tampouco que se ofereça ao sujeito sem trabalho.

Não sei, nem expliquei tudo sobre a condição de ser mulher deficiente, mas trabalhei e compreendi.

Convido, agora, você leitor a refazer comigo os caminhos desta reflexão sobre a deficiência, a sexualidade, a vida das pessoas que entrevistei. 
No próximo capítulo, comentarei sobre a minha trajetória pessoal, situarei a trajetória do tema "deficiência" na literatura e lançarei as referência básicas de um repensar teórica e vivencialmente a deficiência, a condição feminina, a sexualidade e o corpo.

Lançadas assim, as bases deste trabalho, nos capitulos subseqüentes, passaremos a conhecer como estes aspectos e muitos outros foram vividos por sujeitos concretos. Visitaremos, pois, Robson, Márcio, Edna, Nina e Tina. Desta longa conversa que travei com cada um deles. Alguns temas se repetiram, algumas formas foram se delineando, algumas experiências ganharam contornos mais claros e, a partir da análise destes elementos, foi produzido o capítulo "Expressões da Deficiência". Da particularidade da vivência de cada sujeito, surgiu a possibilidade da composição e do entendimento das expressões da deficiência, da sexualidade como algo para além da própria vivência individual. Há também aqui um diálogo constante entre cada indivíduo e o mundo externo. É no entrelaçamento permanente destas dimensões que se constroem as histórias de vida que analisei.

Então, vamos iniciar nosso percurso pelos caminhos que os sujeitos nos apontam. 


\section{DA DEFICIÊNCIA NA LITERATURA EM BUSCA DE UMA OUTRA LEITURA}

\subsection{INTRODUÇÃO}

A minha condição de mulher portadora de deficiência física levou-me a tomar contato com as questões das pessoas deficientes de um modo mais geral e, gradativamente, aprofundar minhas relações com estas pessoas e meu conhecimento do assunto. Neste sentido, participei, de um grupo reivindicatório dos direitos das pessoas deficientes e, simultaneamente, em termos de formação acadêmica, voltei meu interesse para a compreensão da realidade dessas pessoas. Isto acabou por levar-me a ter uma atuação profissional na área de reabilitação e, atualmente, a assessorar o Programa Estadual de Atenção à Pessoa Portadora de Deficiência junto ao Governo do Estado de São Paulo.

A maioria dos profissionais que trabalham com deficientes, primeiramente, têm uma vivência como terapeutas e, posteriormente, em alguns casos, envolvem-se com os movimentos sociais dos deficientes. Minhas experiências fizeram com que uma outra trajetória direcionasse meu trabalho como pesquisadora do assunto. Como conseqưência imediata desta inversão, surgiu o desejo de refletir sobre a deficiência dentro de um enfoque pouco usual nesta área, o da psicologia social. 
A ausência de estudos na área, e mesmo a parcialidade dos raros trabalhos existentes, parecem se assentar sobre a concepção de que este assunto é teoricamente menor e limitado. Situar a deficiência como um fenômeno sócio-político-histórico parece ser uma forma de romper com esta idéia que, nada mais nada menos, é o prolongamento sutil, em termos teóricos, da visão da deficiência como condição limitante do indivíduo.

O número reduzido de profissionais que atuam na área, em virtude das desvantagens trabalhistas e do menor "status" atribuído aos psicólogos que trabalham com deficientes, vêm corroborar esta concepção, que pode ser melhor compreendida se refletirmos sobre o que é concebido como objeto da psicologia de base analítica. Este objeto é definido como a subjetividade do indivíduo, estabelecendo-se comumente uma dicotomia entre realidade interna e externa, onde a segunda é vista, quando muito, como suporte ou fator desencadeante dos processos mentais, estes sim pertinentes ao campo específico da psicologia e merecedores de atenção por esta disciplina científica.

Quando a importância da realidade externa se impõe, como no caso das pessoas portadoras de deficiência - onde a concretude da vivência dos limites pelo indivíduo se dá na prática de seu cotidiano -, estabelece-se um campo intermediário, onde a especificidade e exclusividade deste "psicológico" é, no mínimo, questionada.

Nesta situação descrita ou, por exemplo, quando se procura associar a emergência da loucura, espaço por excelência do subjetivo, a determinantes sócio-econômicos, é compreensível o surgimento de resistências em abandonar a segurança de um objeto de estudo perfeitamente determinado.

Para avançar na discussão sobre deficiência, é preciso questionar-se a dicotomia objetivo/subjetivo, interior/exterior, orgânico/mental, indivíduo/sociedade.

Em última instância, com este trabalho, pretendo mostrar que este campo de pesquisa é amplo e rico em si mesmo, além de ser campo privilegiado para a análise destas questões, à medida em que a deficiência é um fenômeno prismático, oferecendo faces nos planos do corpo e da psique e nos campos individual e social. 
Como já mencionei, é flagrante a lacuna na bibliografia especializada no que se refere a estudos sobre condição feminina e deficiência. Tratar desse assunto exige uma reflexão sobre a identidade da mulher deficiente, considerando-se as relações entre o indivíduo e a sociedade no processo de constituição do sujeito. É necessário compreender como são construídas as articulações entre as representações sociais da mulher, da deficiência e as vivências pessoais das mulheres deficientes enquanto tais. $\mathrm{E}$, logicamente, estas vivências põem em relevo as noções de sexualidade e de corpo à medida que, neste plano, incide tanto a sexualidade feminina como a deficiência.

São parcos os estudos que falam, até mesmo de um modo mais geral, sobre um dos aspectos da condição de ser mulher que é a sexualidade, relacionando-a com a deficiência.

Há alguns livros autobiográficos que contam as vivências sexuais de seus autores. Mas estes são homens e, obviamente, falam de um ponto de vista masculino. Estes temas parecem ser tabus não só para os leigos, como até mesmo para os pesquisadores científicos.

Para compreendermos a evolução e as tendências dos estudos científicos sobre condição feminina e deficiência, é preciso, antes de tudo, analisar a seqüência das publicações ano a ano e suas origens.

As discussões a respeito deste tema tornaram-se mais consistentes a partir da década de 70 e os temas giravam em torno da sexualidade das pessoas deficientes de um modo global. Nesta década, nos Estados Unidos, o enfoque dos artigos estava no reconhecimento de que as pessoas, mesmo deficientes, continuavam a ter necessidades e desejos sexuais, e que, para exercerem este direito, deveriam ter à sua disposição o máximo de informações possível. Outra preocupação que se inicia é sobre a relação entre a auto-estima e a imagem corporal das pessoas deficientes.

Em 1977, aparece o primeiro artigo a respeito da questão da imagem corporal, especificamente, de mulheres adolescentes com escoliose. Na Europa, particularmente na 
França, apresenta-se a preocupação com os aspectos psicológicos, sociológicos, filosóficos, antropológicos e legais em relação ao casamento e à gravidez de pessoas deficientes.

No final da década de 70, os artigos tentam aprofundar mais os problemas que as pessoas deficientes enfrentam para o exercício da sexualidade, propõem e analisam programas de intervenção na área de reabilitação e/ou de educação especial.

A questão específica da mulher começa a ganhar corpo. Já no primeiro número da revista Sexualidade e Deficiência, em 1978, há um artigo sobre sexualidade da mulher deficiente. $O$ enfoque do artigo está nas conseqüências da deficiência no plano biológico, em relação ao desempenho sexual das mulheres. No mesmo ano, há um artigo anterior a este, que tenta analisar as diferenças entre mulheres deficientes e não deficientes.

Ainda naquele ano, há uma publicação cujo título é "Mulheres com Deficiência Física". Embora o título seja abrangente, a maior parte do artigo é dedicada às questões sexuais. Menstruação, masturbação, doenças sexuais e contracepção são aspectos discutidos para cada tipo específico de deficiência. Há também considerações a respeito do relacionamento com pais e atendentes. A questão da auto-imagem continua a ser uma preocupação e vários textos abordam este tema através da pesquisa da auto-representação pictórica de crianças com deficiências.

Em 1979, os artigos versam sobre questões mais específicas. Aparece a preocupação com a atitude dos profissionais de reabilitação em relação à sexualidade das pessoas deficientes.

A revista Sexualidade e Deficiência dedica seu segundo número (1979) à análise do papel do fisiatra, do enfermeiro, do psicólogo, do assistente social, do advogado e do recreacionista com relação ao manejo e à expressão da sexualidade dos pacientes deficientes, além do ponto de vista dos próprios clientes.

Paralelamente a isto, aparece a preocupação de estudar a sexualidade relacionada a tipos específicos de deficiência como, por exemplo, na deficiência visual, na artrite reumatóide, na dupla deficiência auditiva e visual e na lesão medular. Neste último caso, os 
estudos fazem uma distinção entre homens e mulheres. Começa o interesse com o ajustamento conjugal quando um dos membros do casal é deficiente.

A década de 80 se inicia com estudos que abordam experiências de treinamento em programas de intervenção com pessoas ligadas afetiva ou profissionalmente com deficientes. Estes treinamentos visam eliminar o preconceito e mudar o comportamento e a expressão da sexualidade das pessoas deficientes. Os grupos de aconselhamento, fundamentalmente, buscam o oferecimento de informações e a pesquisa de técnicas que facilitem o desempenho sexual das pessoas deficientes.

Há um artigo publicado em 1980 que, diferentemente dos demais, discute o impacto da assistência pública no processo de reabilitação de mulheres deficientes, concluindo que os investimentos financeiros nestes programas de reabilitação profissional têm tido retornos significativos.

Em 1981, há uma grande variedade de temas abordados nos artigos, desde estudos sobre auto-imagem, identidade sexual de deficientes físicos, investigação sobre as conseqüências psicológicas da lesão medular, até a imagem e conceitos veiculados pela televisão a respeito de pessoas deficientes.

Ainda neste ano, há uma primeira revisão bibliográfica de artigos sobre reabilitação, incluindo referências sobre deficiência física, visual, de fala, de problemas de aprendizagem, de deficiência mental, de privação social e cultural e de distúrbios emocionais.

Em 1982, um grande número de publicações - provavelmente decorrentes da declaração pela ONU, em 1981, do Ano Internacional da Pessoa Deficiente - abordam estudos sobre adolescentes deficientes, desde a análise do processo de reabilitação destes pacientes, até o exame da legislação e da política de amparo e promoção do adolescente deficiente.

A questão da sexualidade está incluída nestes estudos, além de haver textos específicos sobre aconselhamento sexual para o lesionado medular e indivíduos com deformidades músculo-esqueléticas. Existem outros sobre escolha de contraceptivos para 
deficientes e pesquisas sobre a relação entre o abuso sexual de crianças deficientes institucionalizadas e a ausência de educação e informação sexual.

Temos ainda um artigo sobre a importância da imagem social de pessoas deficientes e o desenvolvimento e crescimento pessoal destes indivíduos.

Ainda em 1982, foram publicadas oito revisões de livros e artigos sobre pesquisa em reabilitação. Contudo, os temas mais significativos, isto é, com maior número de publicações, com textos mais extensos e consistentes, versaram sobre a sexualidade do deficiente mental e sobre condição feminina e deficiência.

Com relação ao primeiro tema, temos uma publicação americana que investiga a percepção das próprias pessoas deficientes mentais sobre sua intimidade e sexualidade, bem como a percepção das demais pessoas sobre estes aspectos na vida do deficiente mental. Há uma publicação francesa dedicada também à sexualidade do deficiente mental, que trata do aconselhamento genético, casamento, gravidez, autoconceito e de problemas éticos e clínicos associados.

Relacionados à condição feminina, há quatro artigos publicados na Rehabilitation Literature tratando das bases do processo de reabilitação de mulheres deficientes, do aconselhamento profissional, de recomendações para a década de 80 e das condições das mulheres deficientes em diversos países.

Há também um estudo sobre aconselhamento sexual para mulheres com lesão medular e outro a respeito de um programa para o desenvolvimento da independência no auto cuidado de mulheres deficientes mentais severas, durante o período menstrual.

Durante aquele ano, houve um Seminário sobre condição feminina e deficiência, com publicação de três trabalhos apresentados. Estes discutem as oportunidades e as barreiras para a reabilitação de mulheres deficientes, incluindo questões como autoconceito, preconceitos masculinos, oportunidades de educação, de emprego e de desenvolvimento sócio-econômico, barreiras para as trabalhadoras deficientes, além do aspecto relativo ao acesso aos beneficios e serviços sociais. 
Com esta mesma abordagem, há um artigo que discute a condição dos homens deficientes, principalmente, as exigências ligadas ao papel sexual masculino e à imersão destes papéis no relacionamento conjugal. Apresenta também a idéia de que o próprio papel sexual masculino, como tradicionalmente concebido, é uma forma de deficiência.

Em 1984, continuam os estudos sobre sexualidade relacionada aos diferentes tipos de deficiência, agora em países do norte da Europa, principalmente, com atenção especial aos parceiros não deficientes.

Continuam também as preocupações com a posição dos profissionais de saúde e das instituições, no que diz respeito à expressão da sexualidade dos deficientes.

Temos publicadas duas revisões bibliográficas e quatro artigos sobre condição feminina e deficiência. Estes artigos, neste ano, focalizam mais especificamente a situação de discriminação sócio-econômica das mulheres deficientes, tratando agora este assunto de um ponto de vista sociológico e legal.

Em 1985, novamente os temas tornam-se bastante variados e a questão da sexualidade é um dos aspectos analisados no contexto global. Como por exemplo, os artigos que tratam da relação entre deficiência física e narcisismo dentro de uma perspectiva psicanalítica, das crises psicológicas de pessoas doentes ou deficientes, ou ainda, dos efeitos da lesão medular na intensidade da experiência emocional.

Há ainda artigos mais específicos como, por exemplo, um que descreve o programa de reabilitação psico-sexual de homens deficientes com implantes penianos, outros que demonstram a preocupação sobre a veiculação da imagem das pessoas deficientes, através de filmes e livros, bem como a reabilitação de adolescentes deficientes.

Em relação à condição feminina, há um artigo que analisa os serviços prestados por agências públicas no atendimento a mulheres deficientes.

Em 1986, a temática da sexualidade ou da condição feminina é tratada, novamente, como um aspecto a ser considerado. 
No final da década de 80 , percebe-se claramente um declínio do interesse sobre estas questões, embora ainda sejam encontrados artigos que tratem especificamente de programas de treinamento e aconselhamento para o desempenho sexual de deficientes mentais, auditivos e visuais e de adolescentes deficientes de um modo geral.

Em 1987, encontramos somente um artigo que faz uma revisão da literatura sobre sexualidade de indivíduos com lesão medular, enfatizando as diferenças das funções sexuais de homens e mulheres.

Em síntese, podemos afirmar que o interesse pela questão da sexualidade iniciase na década de 70 com um caráter geral, como constatação deste aspecto como um direito inerente à condição humana, paralelamente a estudos sobre auto-imagem. Durante esses anos, evolui para a abordagem de aspectos práticos do desempenho sexual nos diferentes quadros de deficiência, passando pela preocupação com o papel dos diversos profissionais da equipe de reabilitação, em relação à expressão da sexualidade dos pacientes portadores de deficiência. No final da década de 70 e início dos anos 80 , temos a questão da sexualidade sendo tratada como um aspecto dentro de outros contextos como, por exemplo, relacionada com a adolescência, a gravidez e o planejamento familiar para casais deficientes, o desempenho dos papéis sexuais, mais especificamente, a condição masculina e feminina. Estes estudos já têm uma tendência, embora tênue, de análise mais psicossocial do que uma compreensão exclusivamente individual, centrada na preocupação do desenvolvimento de técnicas de intervenção clínica e de aconselhamento. Ao final da década de 80 , há uma diminuição do interesse pelo tema.

Com relação ao enfoque desses artigos, podemos dizer que a grande maioria restringe-se em declarar a possibilidade da demonstração da potência sexual dos deficientes, ou mesmo, o direito destes de ter uma vida sexual ativa, tal como afirma MARTA SUPLICY:

Em relação a sexualidade dos deficientes, o preconceito é enorme, pois thes é vedado o direito à informação e às mesmas emoções e necessidades sexuais dos outros seres humanos. Conseqüentemente, em vez de serem protegidos e compreendidos, vivendo na mais absoluta repressão e ignorância, a situação de um grande número de deficientes é de extrema vulnerabilidade, estando sujeitos à exploração e tendo muito menos condiçães de usufruir o sexo responsavelmente. 
... Hoje, sabe-se que pessoas com inabilitação mental ou fisica não são excepcionais em seus impulsos sexuais. A deficiência mental não determina um comportamento sexual socialmente ameaçador. Alguns paises, como a Holanda, já vão além de tolerar o interesse sexual dos deficientes, passando até a cultivá-lo como fonte real de gratificação, prestando orientação sexual aos deficientes motores durante o processo de reabilitação. (...) Individuos com deficiência motora têm emoções, necessidades de aliviar suas tensões sexuais e de se aproximar afetivamente de alguém. Anseiam por amor como qualquer outro ser humano. (...) Muitos deficientes motores querem ter sexo, e têm direito a ele. (1983, p.311-314)

Fica claro que estes estudos partem de uma concepção de sexualidade como restrita ao coito, às vezes, sendo superficiais, pressupondo que a simples proclamação da sexualidade, como um direito pessoal, fosse suficiente para superar a inegável complexidade da escolha de parceiros sexuais.

Parece haver somente duas alternativas possíveis: a deficiência acarretaria a impossibilidade do exercício da sexualidade ou a deficiência não a alteraria em nada. A meu ver, estas duas colocações são falsas, à medida que uma nega a sexualidade, e a outra, a deficiência, desvencilhando-se do problema de compreender a articulação destes aspectos a nível da vivência individual e mesmo das conseqüências no plano social.

Isto sugere que a articulação entre sexualidade e deficiência é um núcleo de resistência na pesquisa psicológica, que só pode ser contornado mediante a racionalização de que este conhecimento só é necessário para aprimorar as intervenções clínicas dos profissionais de reabilitação. Talvez, por isso, a maioria das pesquisas sejam realizadas a partir do enfoque clínico.

Continuando neste pensamento, a deficiência é considerada, na maioria das vezes, como uma anomalia anátomo-funcional, à qual, posteriormente, são acrescidos sentimentos de aceitação ou rejeição dessa condição limitante do corpo biológico.

Sem negar que pesquisas deste tipo sejam importantes, resta indagar quais as razões desta restrição em conceber a deficiência somente por este ângulo. 
Pretendo refletir sobre estas questões dentro de uma perspectiva psicanalítica que opera profundas alterações nas idéias de identidade, sexualidade e corpo e, por conseqüência, na compreensão da articulação entre a condição de mulher e de deficiente.

Afinal, como se dá a construção da identidade das pessoas deficientes em termos de sexualidade?

No contexto de isolamento social em que vivem as pessoas deficientes - vistas como formando um grupo diferente de outros, mas homogêneo dentro dele mesmo -, a sexualidade destas pessoas também será considerada sob este prisma: a sexualidade dos deficientes será vista como diferente da de outras pessoas, porém, como igual entre as pessoas com deficiência.

Esta diferença pode ser percebida de duas maneiras diversas: a sexualidade ausente ou exageradamente desenvolvida, principalmente nos deficientes mentais. Se há diferenças, estas não são tomadas na sua medida exata.

Este pensamento está de acordo com a negação de um corpo que é diferente. Do mesmo modo, a suposta exacerbação da sexualidade nos deficientes mentais revela a noção de um corpo "sem cabeça", desgovernado, por isso extremamente perigoso, sendo necessário desviar o "intenso" impulso sexual para outras áreas (Lipp, 1981).

O corpo das pessoas deficientes físicas não é reconhecido como fonte de prazer sexual, e sim, na maioria das vezes, como algo a ser "consertado" através de cirurgias, fisioterapia e outros tratamentos. A manipulação do corpo é feita de modo impessoal, por profissionais que não sentem nem provocam prazer. As sucessivas tentativas de atingir o padrão ideal de corpo, na realidade, apontam somente para as diferenças de modo pejorativo (Nallin, 1992).

Gostaria que meu trabalho pudesse lançar luz sobre esses mecanismos relacionados à expressão da sexualidade dos deficientes, dando-lhes voz e mostrando sua sexualidade não como problema terapeutizado, mas, como vivência individual e particular. E creio que isto se dará a partir da interpretação do modo peculiar como cada uma das pessoas 
entrevistadas introjeta as representações sociais sobre sua deficiência. Procurarei também esclarecer a articulação dos significados sociais e individuais da deficiência.

Gostaria ainda de compreender como são constituídas as relações entre as representações sociais da mulher e da deficiência na construção das vivências pessoais de mulheres deficientes. Além disto, pretendo focalizar, mais detidamente, as relações entre as representą̧ões sociais da mulher e as representações sociais sobre o deficiente, verificando nos sujeitos entrevistados suas traduções individuais, a fim de obter alguns esclarecimentos sobre as diferenças de significado da deficiência para ambos os sexos, ou mesmo, verificar se tais diferenças realmente existem. Creio ser importante também explicitar o caminho efetivado pela sexualidade na história de vida de indivíduos deficientes concretos, isto é, analisar os canais de expressão da sexualidade, nestas pessoas em particular, considerando a trama simbólica dos aspectos de seus contextos de vida, tais como: idade, situação sócio-econômica, tipo e grau de deficiência, bem como outros aspectos considerados como significativos para os sujeitos.

\subsection{METODOLOGIA}

Escolhi cinco sujeitos, sendo três do sexo feminino e dois do masculino, portadores de deficiência física congênita ou adquirida, na faixa etária dos 25 aos 35 anos, de nível sócio-cultural médio e baixo. Os sujeitos foram identificados, entre as pessoas com quem eu tinha contato, através de meu trabalho como profissional da área de reabilitação, ou como militante em movimentos reivindicatórios.

Os critérios foram definidos segundo variações importantes da experiência individual, contendo determinações sociais inerentes a cada um deles. Com isso, quero dizer que ser mulher ou homem, ter uma deficiência congênita ou adquirida, pertencer a um ou outro nível social, são fatos de significado marcadamente diferentes, determinando condições concretas e específicas de vida. 
A faixa etária de 25 a 35 anos foi escolhida, porque considero este período como o auge da vida adulta, quando normalmente se espera pela inserção em atividades profissionais, em relacionamentos afetivo-sexuais, pela existência de uma independência pessoal a partir de um amadurecimento interno e de uma maior estabilidade em termos de identidade.

Neste ponto, é conveniente esclarecer o que estou entendendo por deficiência adquirida e congênita e por nível sócio-cultural.

A deficiência congênita é aquela que se instala desde o nascimento ou na primeira infância do indivíduo. Já a deficiência adquirida ocorre na adolescência ou idade adulta.

Quanto ao nível sócio-cultural, trabalhei com dois níveis: médio e baixo, os quais foram definidos a partir da renda pessoal e/ou familiar - caso o indivíduo more só ou com a família - grau de instrução e padrões culturais entendidos como a atribuição de valor a diferentes bens de consumo.

Os sujeitos foram distribuídos, segundo os critérios já explicitados, embora não se tenha buscado uma combinação matematicamente exaustiva: Robson, sexo masculino, nível social médio, deficiência adquirida; Márcio, sexo masculino, nível social baixo, deficiência congênita; Edna, sexo feminino, nível social médio, deficiência adquirida; Nina, sexo feminino, nível social baixo, deficiência congênita; Tina sexo feminino, nível social médio, deficiência congênita.

Devo ressaltar que os nomes utilizados aqui são fictícios.

Para compreender as histórias de vida de cada um, analisei as entrevistas tanto do ponto de vista do conteúdo, quanto da forma e dos sentimentos despertados na relação entrevistado-ouvinte, trabalhando com o conteúdo manifesto e o latente.

Aqui, história de vida, não foi considerada como uma mera biografia, rol de datas e fatos, mas como a história individual produzida por uma pessoa, possuidora de um mundo interno em permanente relação com o contexto histórico e social que a rodeia. 
Estas histórias de vida foram colhidas em entrevistas livres, gravadas e transcritas. O número de entrevistas variou em cada caso, sendo a duração média de cada uma de aproximadamente 60 minutos.

O número de entrevistas para a coleta das histórias não foi fixado porque, por princípio, este processo deve respeitar o ritmo e os limites da própria pessoa entrevistada.

Meu interesse foi obter dados sobre o cotidiano das pessoas deficientes, sua vida sexual e suas vivências afetivas.

Algumas questões básicas nortearam minha investigação: como as pessoas deficientes vivem a realização de relacionamentos afetivo-sexuais? Quais as vivências de cada um na família? No trabalho? Nas demais relações sociais? Quais as expectativas e planos de vida? Qual o significado destes aspectos na vida dos sujeitos? Qual o caminho efetivado pela sexualidade dadas todas estas circunstâncias? Qual a determinação de aspectos como idade, grau e tipo de deficiência e nível sócio-cultural para as vivências destes indivíduos? Quais as diferenças e semelhanças entre os casos de deficiência congênita e adquirida ou entre as possibilidades de expressão da sexualidade em homens e mulheres deficientes? Como se articulam todos estes aspectos em indivíduos concretos, construindo uma organização determinada de subjetividade? Qual o "peso" da deficiência na resultante das operações simbólicas entre o indivíduo e a cultura? Como se articulam o sentido de deficiência e feminilidade nas histórias dos sujeitos? Como se articulam os significados individuais e as representações sociais da condição feminina e da deficiência? 


\subsection{PRESSUPOSTOS TEÓRICOS}

Antes que possamos discutir as inter-relações entre deficiência e feminilidade, é preciso que tenhamos um certo acordo a respeito daquilo sobre o que falamos, particularmente, no que diz respeito à condição de deficiente, já que a tarefa de discernir entre homens e mulheres, creio ser menos problemática, embora não isenta de possíveis equívocos...

Quando falamos em pessoas deficientes, uma série de imagens nos vêm à mente e, num primeiro momento, parece fácil enunciar uma definição clara do que se trata: pessoas a que faltam membros, impossibilitadas de ver ou ouvir, que se utilizam de cadeira de rodas, que têm dificuldades para aprender. Contudo, qual o elemento que é comum a todas elas, que assim as qualificam? Ao enunciar a questão desta forma percebemos que este elemento não existe. Estranhamente, a deficiência se mostra, não por uma positividade, mas sim por uma falta, uma diminuição, uma falha. Por mais que nos pareça um absurdo lógico, o termo que ultimamente se utiliza com mais freqüência para designar estas pessoas é "pessoa portadora de deficiência", ou seja, pessoa que porta uma falta, podemos fazer uma concessão à lógica e continuar trilhando este caminho. Parece natural que a deficiência esteja ligada à idéia de falta, de limite. Entretanto, ainda, poderíamos nos perguntar, falta e limite do quê? Ora, falta ou limitação de alguma função ou atividade corporal. Mas, a uma pessoa sem a última falange do dedo anular ou a alguém com miopia, podemos chamar de deficiente?

Será que se trata de uma questão de grau de limitação? Mas, uma pessoa com paralisia cerebral com componentes atetóides pode deambular e realizar praticamente todas as atividades, tendo um bom grau de mobilidade, ainda que com uma série de outros movimentos dispensáveis para a realização do ato. Contudo, a ela denominamos deficiente.

Então, será que se trata, não só da limitação, mas da forma como é realizada a atividade? Porém, a alguém com desfiguração ou deformidades faciais, também chamamos de deficiente e ela não possui necessariamente limitação na realização de atividades, nem as 
executa de forma diversa da comumente realizada. De que limitação, ausência ou falha verdadeiramente falamos?

A Organização Mundial de Saúde (OMS) com o objetivo de esclarecer tais idéias e sistematizá-las, em um esforço de conceituação, acaba por reconhecer a deficiência como um dos três níveis de conseqüências possíveis de ocorrer ao reverso do processo evolutivo de uma enfermidade ou de qualquer outro agravo à saúde, além do óbito ou da cura, de acordo com o seguinte esquema: enfermidade $\ldots .->$ seqüela $\ldots . .>$ incapacidade ...-> deficiência.

A natureza destas várias dimensões das conseqüências das doenças, suas definições e três esquemas distintos de classificação são o conteúdo da "Classificação Internacional de Seqüelas, Incapacidades e Deficiências - Manual de Classificação das Conseqüências das Doenças", elaborado por um Comitê de Especialistas da OMS, em 1980.

A intenção desse estudo é identificar categorias ou grupos de pessoas que se enquadrem nestes critérios, visando oferecer um instrumento para estudos estatísticos dos serviços de saúde, para concessão de benefícios econômicos, planejamento em saúde pública, em seguridade social, em administração e para elaboração e execução de políticas sociais.

Desta forma, a seqüela (deficiéncia, disability) seria "toda perda ou anomalia de uma estrutura ou função psicológica, fisiológica ou anatômica" (OMS, 1980), sendo a exteriorização, a nível orgânico de uma doença ou qualquer outro agravo à saúde. Estas perdas ou anormalidades podem ser temporárias ou permanentes, inatas ou adquiridas, entre as quais se incluem os defeitos ou perdas em um membro, órgão, tecido ou outra estrutura do corpo, incluindo os sistemas próprios da função mental.

A incapacidade (discapacidad, impairment) seria "toda restrição ou ausência, devida a uma seqüela, da capacidade de realizar uma atividade da forma ou dentro da margem que se considera normal para um ser humano" (OMS, 1980), sendo a concretização a nível do individuo de uma limitação funcional. 
As incapacidades podem ser temporárias ou permanentes, reversíveis ou irreversíveis, progressivas ou não. Sua principal característica é a objetivação, explicitação de uma limitação funcional como uma realidade na vida diária do indivíduo.

A deficiência (minusvalia, handicap) seria "uma situação de desvantagem para um determinado individuo, conseqüência de uma seqüela ou de uma incapacidade, que limita ou impede o desempenho de um rol de ações, que é normal no seu caso, considerando-se sua idade, sexo e fatores sociais e culturais" (OMS, 1980). Desta forma, a deficiência é concebida como um fenômeno relativo às conseqüências sociais e ambientais para o indivíduo que possui seqüelas ou incapacidades.

Para exemplificarmos a seqüência, teríamos a seqüela identificada como a anomalia do órgão da audição ou como a lesão medular; a incapacidade, como a limitação para escutar ou a restrição da deambulação e, por fim, a deficiência de comunicação ou de independência física, respectivamente. É importante ressaltar, que nos referimos à seqüela sempre enquanto localização corporal, à incapacidade usando verbos, portanto, ligada à ação e à deficiência, com atributos relacionais.

Para a OMS a seqüência - seqüela-incapacidade-deficiência -, não é necessariamente completa e invariável. Por exemplo, pode-se ter uma seqüela sem uma incapacidade, e uma incapacidade sem uma deficiência.

Uma criança que ao nascer não tenha a unha de um dedo, possui uma malformação congênita. Porém, provavelmente, não terá nenhuma dificuldade quanto ao funcionamento da mão. Por isso, não se pode falar em incapacidade, e, também, não é provável que ocorra uma situação de desvantagem ou deficiência.

$\mathrm{O}$ caso de um indivíduo ter uma deficiência sem uma incapacidade pode ser exemplificado por uma pessoa que, mesmo depois da remissão de um episódio psicótico agudo, experimenta uma série de situações sociais de desvantagens, sem existir mais a incapacidade.

É importante ressaltar ainda que o Comitê de Especialistas afirma que não se pode correlacionar o grau de uma incapacidade com o de uma deficiência. Outros fatores como, 
por exemplo, apoio familiar, podem minorar uma situação de deficiência, ainda que relacionada a um caso de grave incapacidade. Ou, contrariamente, um indivíduo com uma incapacidade menos grave pode experimentar uma grande desvantagem e discriminação social se não puder contar com este apoio. Por outro lado, algumas incapacidades podem atrasar ou mascarar o desenvolvimento ou reconhecimento de outras capacidades. Por exemplo, um distúrbio de linguagem pode limitar a expressão e o reconhecimento das capacidades cognitivas.

Agora, parece-nos que tudo está correto e claramente colocado. Porém, ao examinarmos um pouco mais detidamente estas definições, vamos perceber que, aparentemente, tudo se encaixa por uma operação enganosa. As contradições e conflitos entre as idéias subjacentes são "resolvidos" pela separação das "dimensões" da deficiência e posterior correlação com as partes da fragmentação habitual corpo-mente-meio social. A seqüela é identificada como dimensão orgânica, a incapacidade como resposta/reação pessoal e a deficiência, como fenômeno relacional, social.

O discurso que fundamenta a elaboração destes conceitos é

a necessidade de oferecer à sociedade, desprovida de informações a respeito da deficiência e às distintas organizações que se ocupam do tema, uma definição abrangente e sem ambiguidades, a fim de minorar os malentendidos e distorções (OMS, 1980).

Isto mascara o fato de que, na verdade, a sociedade dispõe de diferentes idéias sobre deficiência e que estas ideias apoiam e são realimentadas por diferentes práticas sociais, além de retirar o caráter histórico e dinâmico dessas representações sobre deficiência.

$\mathrm{Na}$ realidade, mesmo estes conceitos são e serão re-interpretados na práxis social. Para justificar a necessidade de uma política de prevenção e realçar tal aspecto, pode-se enfatizar o caráter seqüencial e evolutivo destas condições, dentro de uma linearidade causal, correlacionando as intervenções de prevenção primária, secundária e terciária ou reabilitacional, respectivamente, aos níveis da lesão, da incapacidade e da deficiência. Ou, pode-se tomar estes níveis como dimensões simultâneas de um mesmo fenômeno com faces no orgânico, no pessoal 
e no social. Ou, ainda, como fenômenos distintos e somente superpostos em algumas circunstâncias. Esta última interpretação, por ressaltar um caráter de grau de comprometimento, por exemplo, pode fundamentar o fornecimento de subsidios ou benefícios econômicos.

Portanto, fica claro que é impossível ou, no mínimo inadequado, tomarmos uma definição única. Conceituar deficiência. Será mais útil perscrutarmos as diferentes práticas para compreender do que se fala e do que falamos.

Tanto o nascimento de uma criança deficiente, como o processo de instalação de uma deficiência, ocorrem em um contexto social que os precede e thes atribui um significado, aliás, como ocorre com qualquer fenômeno humano.

Tal como os gritos do recém-nascido não são para sua mãe meros sons inarticulados, mas já são palavras (porque são interpretados, no discurso desta, como demanda de calor, de alimentação e de afeto), a vivência de ter uma deficiência insere-se num discurso já constituído e pré-existente. Ao mesmo tempo, cada indivíduo com deficiência, a partir de sua história de vida peculiar, irá montar e remontar esse contexto indefinidamente, num processo permanente de re-significação.

Desta forma, não é possível falar de um discurso único sobre "deficiência", as interpretações sociais são múltiplas e, mesmo nas práticas "especializadas", há diferenças significativas no eixo central destas representações.

No atendimento educacional e de reabilitação de pessoas deficientes, podemos identificar diferentes conceitos de deficiência que subjazem a estas práticas.

A terminologia médica explicita estas concepções de forma mais clara, embora possamos estendê-las para além da área médica, reencontrando-as em inúmeras outras formas de intervenção técnica.

Em termos de reabilitação, as leituras clínicas e/ou terapêticas vão num continuum, que compreende desde os processos de abstração, que originam as classificações nosológicas, os "quadros de deficiência", até a consideração do indivíduo concreto, onde a 
deficiência pode ser entendida como uma limitação surgida da relação deste indivíduo com ele mesmo e com o meio circundante, e não mais como um dado natural.

Para a ortopedia, como o próprio termo alude, - a arte ou ciência da correção, do endireitamento das crianças -, a deficiência é entendida como a deformidade corporal. A anomalia localizável no corpo morfológico e estruturalmente entendido, é a lesão. Daí, a adoção freqüente de aparelhos e cirurgias visando a correção, substituição e apoio para membros ou partes do corpo. Na realidade, mesmo os exercícios fisioterápicos, as intervenções de terapia ocupacional ou pedagógicas podem ser "ortopédicas", caso visem a "conformação" destes corpos ou condutas desviantes.

De outro lado, existem as concepções que vêem a deficiência surgindo do confronto de uma limitação do indivíduo com um determinado contexto ambiental. Dentro disto, a prática fisiátrica pressupõe a deficiência como um fenômeno surgido da relação do homem com o meio circundante, a partir de um enfoque ecológico.

Nesta visão, a deficiência é circunscrita a situações específicas e/ou circunstanciais como, por exemplo, a situação de um indivíduo com uma lesão medular, que precise ir ao segundo andar de um prédio, cujo acesso só se dê por escadas. Tal situação faz emergir uma deficiência, transformando uma limitação individual de ordem funcional em impossibilidade de realizar uma determinada ação de significação sócio-interacional. Este indivíduo é, neste momento, portador de uma deficiência.

Contudo, tal visão não dá conta do fato de que, apesar da incapacidade aí ser entendida dentro de um contexto determinado, é a pessoa que globalmente é chamada de deficiente. Não se trata de um problema de nomenclatura, de tratamento, mas sim da relação que a presença da deficiência traz, por ser definida e definidora de uma situação social de segregação e marginalização.

Dentro desta última concepção, a diabete, que é um distúrbio não visível, e a miopia, que é facilmente perceptível, são consideradas deficiências, ainda que comumente seus portadores não sejam reconhecidos como pessoas deficientes. 
As leituras sobre deficiência, que consideram a relação indivíduo/sociedade, encontram-se na base da prática organizativa das pessoas deficientes de origem mais recente. Mas às diferentes formas de organização correspondem diferentes modos de compreender a relação indivíduo/sociedade.

$\grave{A}$ concepção de que os deficientes constituem um grupo social e homogêneo entre si e diferente dos demais, corresponde a uma organização de grupos reivindicatórios que excluem de sua constituição as pessoas não deficientes e concebem as suas questões como isoladas das demais questões sociais.

Numa outra concepção, identificável nas reivindicações de determinados grupos de deficientes, a divisão econômica da sociedade em classes sociais é considerada como mais radical do que a existente entre deficientes e não deficientes. Nesta visão, a importância dada à organização econômica da sociedade prevalece sobre a concretude do estigma. Isto é, os desníveis sociais prevalecem como explicações da marginalidade das pessoas deficientes sobre a explicação baseada na existência do estigma. Se há marginalização, primordialmente, é por uma questão econômica e, secundariamente, por uma questão psicossocial.

A marginalização é entendida de forma diversa nestes dois tipos de compreensão. Na última, a deficiência se superpõe à pobreza, agravando a marginalização, enquanto que na primeira, a marginalização passa pela noção de estigma.

O estigma é um conceito assentado na teoria dos papéis, sendo fruto de um processo social, de uma rede de interações que envolvem dois papéis básicos: desviante/normal, onde se prevêem as reações de um e de outro. $O$ estigmatizado é aquele que tem um atributo duradouro que o desqualifica socialmente (GOFFMAN, 1982).

O estigma tem como função referendar a sociedade tal como está, à medida que ao estabelecer as transgressões, confirma a norma, além das funções adicionais, como a redução da possibilidade de escolha do par sexual.

Apesar do conceito de estigma apoiar-se na teoria dos papéis, o papel pode ser entendido de diferentes formas, desde uma concepção behaviorista, cuja tendência é o da 
eliminação do conflito entre a prescrição social do papel e a resistência à assunção deste pelo individuo, até as posições que compreendem o conflito como inerente à condição humana, e procuram localizá-lo no âmago do indivíduo e da cultura. E aqui surge a questão da possibilidade ou não de transformação social e individual, da possibilidade ou não do indivíduo opor-se às cristalizações dos costumes, da atitude conformista ou revolucionária.

O conceito de pessoa deficiente, dentro desta teoria, só existe enquanto oposição em relação ao conceito de pessoa não deficiente. O normal é o não deficiente e o deficiente é o não normal. Entretanto, em uma relação social concreta, as pessoas usam estes conceitos independentemente, absolutizando-os.

A relação entre deficientes e não deficientes, para ser de fato uma relação interpessoal, precisaria ultrapassar o papel. No relacionamento entre pessoas, a deficiência seria apenas uma característica a ser incluída no contexto interpessoal.

O relacionamento entre pessoas deficientes e não deficientes será edificado a partir da escolha de características tidas como iguais, que servirão para a construção do sentimento de igualdade entre deficientes e não deficientes. As características escolhidas dependerão do valor a elas atribuído pela cultura. Por exemplo, o relacionamento de pessoas só com deficiência física e não deficientes será baseado naquilo que ambas tenham como valor positivo, ou seja, a intelectualidade. Assim, deficientes e não deficientes, como os citados, poderiam mais facilmente ter um relacionamento como colegas de estudo, sendo mais difícil manterem um relacionamento fora deste domínio da razão. O relacionamento se tornará mais tenso quando envolver aspectos ligados ao corpo.

A relação deficientes e não deficientes, sociologicamente falando, seria definida a partir de um terceiro elemento (não deficiente), excluído, ou seja, o deficiente se identificaria com outro deficiente, a partir de uma norma social que os exclui.

Ainda que estes papéis estejam, em maior ou menor grau, incluídos na identidade de cada indivíduo, a nível pessoal, o peso destes conceitos para determinação da 
relação variará em cada caso. Os papéis sociais serão traduzidos individualmente, e estas traduções assumirão tantas formas quantas forem as relações estabelecidas pelo indivíduo.

Para entender a identidade individual é preciso estudar o indivíduo através de suas relações com os outros, sua posição no contexto social. Como diz LAING: "Todas as identidades exigem um outro - alguém e atrovés de cujo relacionamento a auto-identidade é efetivada" (1982, p.78). "A identidade da pessoa não pode ser completamente abstraida da sua identidade para os outros" (1982, p.82). Assim, uma pessoa deficiente se sente como tal e assume diversas características, porque os outros a vêem assim e conseqüentemente esperam dela certos comportamentos.

A identidade individual de uma pessoa deficiente não se esgotaria na sua identidade social, mas seria permeada por ela. Os papéis sociais estão acoplados à identidade individual, em uma relação que os confirma ou nega, sem contudo, poder-se dizer que haja a possibilidade de um desvinculamento total com estes papéis.

Isto nos leva de volta à questão da identidade social/individual a que nos fala Goffman e novamente a relação indivíduo/sociedade é problematizada.

Segundo ERIKSON, trata-se de

um processo localizado no âmago do individuo e, entretanto, também no núcleo central da sua cultura coletiva, um processo que estabelece, de fato, a identidade dessas duas identidades $(1972$, p.40).

Dentro das correntes de pensamento das teorias psicodinâmicas, o processo de formação da identidade vai na linha de uma diferenciação e integração crescentes do indivíduo.

Em termos psicológicos, a formação da identidade ocorre a partir de uma reflexão simultânea, isto é, como fruto da maneira como o indivíduo se julga, a partir da percepção que ele tem de como os outros o julgam. Logicamente, tudo isto ocorre de maneira inconsciente. 
O processo da construção da identidade está sempre mudando e implica numa crescente diferenciação do eu. $\mathrm{O}$ indivíduo vai ganhando e atribuindo um significado cada vez maior para si e para os outros, desde a pessoa materna até a humanidade.

A formação da identidade inicia-se no primeiro encontro do bebê com a mãe, como duas pessoas que podem se reconhecer mutuamente. Os braços da mãe, ao segurar o bebê, deverão ser os muros que sustentarão a construção de uma nova individualidade, deverão ajudar a construir os limites do corpo do bebê, sem aprisioná-lo.

Sabemos o quanto são importantes as primeiras experiências do bebê para a construção de sua identidade e a conseqüente possibilidade de conhecer o mundo e reconhecerse nele.

Assim, o início da percepção do mundo pode ser localizado no primeiro contato do bebê com o seio materno, que é a mais importante fonte de sensações de prazer ou de dor. Um fator importante para o equilíbrio entre satisfação e frustração é a possibilidade de viver a sensação de comunhão com o mundo. A sensação de fusão entre o eu e os objetos, ante a necessidade de organizar as experiências de vida e adiar a satisfação real, dimimuindo a ansiedade e os impulsos agressivos. Além disso, há a necessidade básica de descobrir a identidade na diferença, o que abre a possibilidade da generalização e a compreensão da realidade, sendo uma fase indispensável na adaptação a esta realidade. É preciso viver a ilusão da identificação com o outro, a fantasia da auto-suficiência, para que com as progressivas experiências se possa descobrir os próprios limites e capacidades individuais num processo contínuo de diferenciação.

O desenvolvimento de um ego maduro, capaz de estabelecer relações objetais, em que o objeto é reconhecido como independente do sujeito e de suas necessidades e desejos, é feito predominantemente por meio da experiência sensorial. Paralelamente, ocorrerá a diferenciação do outro e da integração da percepção de si mesmo como um objeto unificado. 
Dentro desta concepção, a deficiência não é atribuição, imposição social exterior ao indivíduo. As idéias, preconceitos, não são exteriores, constituem, constroem a identidade individual/social. É uma relação da parte com o todo de uma pessoa.

A deficiência não pode ser "superada" pela negação do preconceito, porque não se pode sair de si mesmo e olhar a "sociedade" por fora dela.

Nesta linha de pensamento, a deficiência seria um dado da experiência individual, carregada de valorarão cultural a ser incluída na estrutura de personalidade do indivíduo. E seriam estas características desta estrutura que transformariam o dado e seriam por ele transformadas.

Em uma estrutura, um elemento muda o todo e vice-versa. Assim, a deficiência é uma característica individual que pode alterar o todo do indivíduo, mas pode ganhar um novo significado dependendo deste todo. A cada situação, uma característica é organizadora da estrutura, e haverá tantas diferenças de atuação num relacionamento, quantas forem as vivências interpessoais. A deficiência pode ser ou não uma característica relevante, dependendo da situação vivida.

Estas correntes de pensamento, base da psicologia do ego e da antipsiquiatria, pressupõem uma integração constante no desenvolvimento da personalidade, pensando a constituição do sujeito pela diferenciação com o mundo, mas "desprezam", ou pelo menos, consideram diferentemente a clivagem interna do sujeito proposta pela psicanálise, com a qual estas teorias têm uma ligação.

Para a psicanálise, o eu não é primordial, nem unitário, emergindo a partir de um determinado momento e, somente, podendo ser referendado a partir de um outro. Aqui a noção de individuo é abandonada.

Fazendo uma redução bastante drástica na teoria freudiana ao fazer esta exposição, poderíamos dizer que o bebê não distingue, no primeiro momento, o mundo exterior de si mesmo, estabelecendo-se um continuum entre bebê e seio. Mas, ao sentir fome, o bebê alucina o seio materno e frente à incapacidade da alucinação extinguir a fome, este aprende a 
distinguir entre o seio alucinado e o seio real, estabelecendo-se a diferença entre si e o outro. Esta distinção seria o modelo de todas as distinções ulteriores.

Sob o domínio do princípio do prazer, o sujeito acolhe no ego os objetos que the são oferecidos como fonte de prazer e os introjeta. Por outro lado, afasta de si tudo aquilo que em seu próprio interior, constitui motivo de desprazer. Isto implica na mobilidade permanente da fronteira entre o dentro e o fora.

"Deste ponto de vista, não haveria nem sujeito nem objeto determinados e sim, apenas, a representação do continuum no qual o mundo $e$ o sujeito seriam a mesma coisa. (...)

É a propósito da ruptura do continuum bebê/seio que Lacan faz intervir a "fase do espelho". Isto porque a descoberta da imagem no espelho faz com que o bebê ascenda a representação de seu próprio corpo como unidade, nisto semelhante à mãe. Segue-se o momento em que vai se estabelecer a relação dual com a mãe, ao mesmo tempo em que o ego se define como imaginário (no duplo sentido de proveniente da imagem e do oposto a simbólico). (...)

Esta relação dual seria rompida de dois lados: pelos primeiros momentos da simbolização e pela intervenção do pai. (...) Rompendo a unidade indiferenciada da vivênvia imediata, o individuo ascenderia ao primeiro degrau do simbólico nomeando o objeto, a si mesmo e a diferença entre ambos." (MEZAN, 1986, p.363-365)

Sendo a linguagem, uma instituição social, ao reconhecer-se como separada da mãe, a criança se submeteria às leis da linguagem, que são as leis do mundo social.

Diante da emergência do simbólico, Lacan fala de dois sujeitos. O sujeito do enunciado, ligado ao social, ao conteúdo manifesto e o sujeito da enunciação, excêntrico ao primeiro.

Aqui podemos pensar numa diluição do dado "deficiência" a nível individual. Ela irá se inscrever enquanto sentimentos, afetos, idéias, representações no imaginário e no simbólico.

Apesar de uma compreensão muito mais radical, rompendo inclusive com a exterioridade indivíduo-sociedade, a psicanálise, ou melhor, Freud, irá falar do coletivo como 
análogo ao individual, deixando de considerar este como mais do que a mera somatória dos individuos.

Assim, todo o imenso campo relativo a como a cultura atribui significado à deficiência fica a ser explorado.

Esta questão da atribuição de significado social a determinadas condições dos indivíduos parece-me fundamental, inclusive, porque é orientadora das condutas destes mesmos indivíduos e, portanto, deve ser retomada no tocante à condição de mulher.

As representações sociais da mulher, do mesmo modo que as representações sociais das pessoas deficientes, são um conjunto de concepções sobre o modo pelo qual estes indivíduos relacionam-se consigo mesmos, com os outros e com as coisas do mundo, dinamicamente construídas por estes mesmos agentes sociais, ao mesmo tempo em que são organizadoras de suas ações.

\section{MOSCOVICI, citado por VIOLANTE (1984) afirma que}

a representação não é um reflexo de um objeto na consciência, mas é uma modelagem do que é dado do exterior ... uma reconstrução do dado no contexto dos valores, das noções e das regras ... a partir das relações do individuo com os objetos e das suas relações sociais.

Se por um lado, as representações sociais são uma forma de apreensão do mundo, porque são ao mesmo tempo constituídas e constituintes da práxis social, por outro, justamente, o ocultamento das ligações de sua produção a um determinado contexto social e histórico acaba produzindo uma falsa universalidade e, por exemplo, a criação da idéia de uma "natureza feminina".

Branca M. ALVES e Jacqueline PIT ANGUY afirmam

$o$ 'masculino' e o 'feminino' são criações culturais e, como tal, são comportamentos apreendidos através do processo de socialização que condicionam diferentemente os sexos para cumprirem funções sociais especificas e diversas. Essa aprendizagem é um processo social. Aprendemos a ser homens e mulheres e a aceitar como 'naturais' as relações de poder entre 
os sexos. A menina, assim aprende a ser doce, obediente, passiva, altruista, dependente, enquanto que o menino aprende a ser agressivo, competitivo, ativo, independente. Como se tais qualidades fossem parte de suas próprias 'naturezas'. (...) Da mesma forma, a mulher seria emocional, sentimental, incapaz para as abstrações das ciências e da vida em geral, enquanto a natureza do homem seria mais propicia à racionalidade (1981).

A "naturalização" desses processos sociais formam a base da assimetria das relações entre os individuos. No caso da mulher, a cultura, apoiando-se na constituição biológica, enfatiza, por exemplo, a reprodução, que acaba por constituir-se como elemento da essência do ser feminino. Na realidade, como afirma Simone de BEAUVOIR, a mulher é identificada como representante e mediadora do homem com a própria natureza, o que pode, até mesmo, ser ilustrado com as freqüentes associações do corpo feminino com a terra, com as vinculações da mulher com inúmeros fenômenos e elementos naturais como as colheitas, a Lua, etc. E é nesta qualidade que passa a despertar a ambiguidade das relações do homem com a natureza, o desejo de transcendê-la, subjugando-a e o temor e a admiração, frutos da consciência de sua condição carnal, afinal ele sabe que a natureza é primordial à sua existência, ao mesmo tempo que o condena à finitude, à morte (1980).

Portanto, não se trata de postular o estudo da essência do feminino, mas sim de compreender o processo de construção da condição feminina, ou mesmo das imagens e representações que permeiam esta condição nos meandros de seu engendramento.

Quando analisamos, lado a lado, as concepções de deficiência como condição limitante de um corpo "anormal" e as de feminilidade apoiada em um corpo representante da natureza imediata, podemos perceber que é a partir da idéia de corpo que nos será possível construir as articulações entre identidade, feminilidade e deficiência.

Já destaquei a importância da formação do esquema corporal para entender como o indivíduo se instrumentaliza para estar no mundo e atribuir-lhe significado. Quem eu sou, implica em como eu vivo meu corpo. 
Ao pensarmos que o bebê dispõe apenas de seu corpo para dar expressão a seus processos mentais, podemos entender o sentido da afirmação de Freud de que "... o ego é, primeiro e antes de mais, um ego corporal".

Esta vivência corporal passa pela relação com o outro, como ele vê, sente e toca o meu corpo, começando com a mãe que ao acariciar o bebê inscreve em seu corpo uma diferença de estado imediatamente acessível que é o prazer sexual. Isto só é possível pelo fato da mãe também experimentar o prazer do toque. Esta experiência de prazer é vivenciada integralmente pelo corpo como unidade.

Mas é importante esclarecer de que corpo estamos nos referindo. Estamos utilizando a noção de corpo, enquanto um conjunto de zonas erógenas, ou seja, o corpo só é vivenciado e passa a ter significação a partir das sensações de prazer e desprazer que ultrapassam os limites do fisiológico, porque englobam o desejo.

No dizer de CHAUÍ,

O corpo que não é coisa nem idéia, mas espacialidade, motricidade, recinto ou residência e potência explorativa, não é da ordem do 'penso', mas do 'posso'. É ser sexuado, pois o sexo não é causa nem efeito de manifestações fisicas do desejo, mas atmosfera sexual, maneira de existir com ou contra os outros, de viver neles e por neles (como no sonho e na neurose), de resgatar ou de perder o passado na criação ou na repetição do presente.

$\dot{E}$ expressivo, pois a linguagem não é processo impessoal do aparelho fonador na tradução sonora de essências silenciosas, mas gesticulação vociferante, dimensão da existência corporal onde as palavras encarnam significações e a fala exprime nosso modo de ser no mundo intersubjetivo (1981, p.225).

Entretanto, no contexto cultural em que vivemos é transmitida ideologicamente uma divisão entre mente e corpo, de modo que a percepção do corpo é mediada por valores que enaltecem a razão e onde as sensações, as emoções são negadas. Neste tipo de concepção, o corpo é visto como um instrumento a ser utilizado para o prazer ou para o trabalho, implicando necessariamente que esteja em "bom estado". Esta segunda divisão entre trabalho e prazer também é ideológica e sustenta a estrutura social vigente. Esta visão do corpo vai determinar a 
visão do mundo e dos outros como objetos a serem utilizados a serviço de um sujeito pensante. A utilização do corpo como instrumento de prazer ou de trabalho vai depender da posição social que ocupamos, ou seja, da classe social a que pertencemos.

Para a psicanálise, a sexualidade não é uma categoria em separado do comportamento humano. Neste sentido, não é passível de definição, não pode ser objeto de estudo de uma ciência que se fundamenta na delimitação de campos de conhecimento excludentes.

A sexologia, enquanto ciência positiva, estuda a sexualidade como coisa concreta, pretendendo tirar leis gerais, válidas para todas as pessoas, que regem 0 comportamento sexual humano. Para tanto, torna o fenômeno sexualidade humana um objeto científico, abstraíndo dele a condição de ser social e histórico, transformando-o em um objeto atemporal, logo num objeto morto (CHAUí, 1981).

Quando se dá uma definição positivista para um fenômeno, pretende-se determiná-lo completamente naquilo que ele é ou venha a ser, isto é, pretende-se ignorar as contradições inerentes ao objeto, e é isso que faz com que ele se atualize em cada momento e em cada indivíduo. No caso da sexualidade nega-se, por exemplo, a vivência particular de cada um, construída dentro de determinado contexto social e histórico.

Marilena CHAUÍ esclarece, a partir do Vocabulário de Psicanálise, de LAPLANCHE e PONTALIS,

que a sexualidade não se confunde com um instinto sexual porque um instinto é um comportamento fixo e pré-formado, caracteristico de uma espécie, enquanto a sexualidade se caracteriza por grande plasticidade, invenção e relação com a história pessoal de cada um de nós. Nesse dicionário, sexualidade não designa apenas as atividades e o prazer que dependem do funcionamento do aparelho genital, mas toda uma série de excitações e atividades, presentes desde a infância, que proporcionam prazer irredutivel a alguma necessidade fisiológica fundamental (respiração, fome, excreção) e que se encontram presentes como componentes da chamada forma normal do amor sexual. A sexualidade não se confunde com um instinto, nem com um objeto (parceiro), nem com um objetivo (união dos órgãos genitais no coito). Ela é polimorfa, polivalente, ultrapassa a necessidade fisiológica e tem a ver com a simbolização do desejo. Não se reduz aos órgãos genitais (ainda que estes passam ser privilegiados na sexualidade adulta) porque qualquer 
região do corpo é suscetível de prazer sexual, desde que tenha sido investida de erotismo na vida de alguém, e porque a satisfação sexual pode ser alcançada sem a união genital (1984, p.14-15).

Na realidade, a sexualidade perpassa todos os atos humanos, na medida que é um modo peculiar a cada pessoa de se relacionar com as coisas do mundo e consigo própria.

O canal de expressão da sexualidade:

é o sentimento,

é o sentido,

é a mente,

é a corporeidade, é a carne e o espírito,

é mais do que tudo isso,

é a sua união,

é o corpo.

A forma peculiar que cada sujeito constrói-se no mundo corresponde uma vivência específica da deficiência, do papel de homem ou mulher, da sexualidade e de seu entrelaçamento a nível da experiência do corpo próprio. Desta forma, no próximo capítulo, conheceremos algumas pessoas deficientes, com determinadas características pessoais, vivendo em determinados contextos sociais. Aproximemo-nos, pois, destas histórias que nos contam, tentando entender a sua urdidura, o modo. que se constroem e reconstroem-se a si mesmos.

Que eles sejam, agora, artífices deste repensar a deficiência nos espaços sociais e individuais. 


\section{FEMININA}

Oh! Male, me explica, me ensina, me diz o que é feminina. Nâ é no cabelo, no jeito, no olhar, é ser menina por todo lugar.

Oh! Mae, entalo me ilumina, me diz, como é que termina. Termina na hora de recomeças, dobra uma esquina no mesmo lugar (...) 


\subsection{MAGEM: A RECONCEITUAÇÃO MERCADOLÓGICA A História de Robson}

Robson é um rapaz de 31 anos que usa cadeira de rodas em virtude de uma paraplegia causada por lesão medular ocorrida num acidente, conforme ele mesmo conta, iniciando sua história.

Contrariamente aos outros entrevistados; realizei somente um encontro com Robson, em condições também bastante diferentes dos demais. No contato telefônico para marcarmos a primeira entrevista, ele sugeriu que a realizássemos em um barzinho de amigos seus, ao final da tarde. Apesar de eu ter apontado que um lugar reservado talvez se constituísse em um local mais adequado, Robson insistiu em sua sugestão. De fato, não creio que a entrevista tenha sido "prejudicada", aliás, o clima misto de relato pessoal e reflexão sobre a questão da deficiência é coerente com o espaço físico escolhido: misto de intimidade e coexistência pública.

As primeiras palavras de Robson objetivam sua identificação. Ele enuncia seu nome completo e sua idade. Na verdade, fala de duas idades: os anos de nascido e o tempo 
transcorrido desde a aquisição da deficiência. Esta segunda referência está destacada, porém faz parte integrante de seus anos de vida.

A partir daí relata a causa da sua deficiência: um acidente.

"Sou o Robson L.P., tenho 31 anos e 12 de lesado medular, de paraplegia. Foi um acidente com arma de fogo em 1980. Olha, meu acidente, foi um acidente até que as pessoas acham até engraçado, porque eu mesmo dei um tiro em mim mesmo."

Refletindo sobre o ocorrido com humor, fala de uma percepção do fato como desprovido de propósito, sem sentido. Fala que outras causas acidentais de deficiência guardam uma certa intencionalidade ou uma "razão" moral e social. Há um contexto a que se referem. No seu caso não. Parecem não existir circunstâncias que envolvam o acidente, muito menos múltiplos agentes. Só há ele, a sua ação e reflexão.

Não há culpados, fora ele mesmo. Então com quem se revoltar? Com quem partilhar a culpa?

Há uma constatação, aparentemente sem juízo de valor de que para uma ação descuidada corresponderam conseqüências graves a nível pessoal. Mas não há um sentimento de injustiça, pelo contrário.

"Eu estava na verdade é..., brincando, com uma arma, mostrando pra um ..., brincando com a arma. Sabia que ela estava carregada, mas, eu imaginava que ela estava travada, que eu havia travado essa arma, só que acho que devo ter esquecido alguma coisa. Ela disparou atingindo a medula. Foi um acidente assim muito besta. Muito besta. Não foi nem um pouco chique. Tem pessoas que têm acidentes chiques entendeu? Sofre acidente de avião, sofre acidente num assalto, e salva algumas pessoas, alguma coisa assim no cumprimento do dever. O meu foi muito babaca, muito besta entendeu? $\mathrm{Na}$ verdade assim tem até o lado legal. Acho que é até o único lado legal, que é que eu não tenho ninguém pra culpar, eu acho que a cagada foi minha mesmo, o erro foi meu, a fatalidade foi minha, a falta de atenção foi minha. Então, eu simplesmente hoje pago por uma falha exclusivamente minha. Todo acidente é besta, não deixa de ser, mas eu vejo algumas pessoas acidentadas por outros que ficam com uma certa mágoa, que ficam com uma certa revolta, fica uma coisa assim ... A minha não! A minha foi eu mesmo, não tem jeito. Assumo a minha cagada e pago por isso, mas é por aí." 
Robson qualifica o momento da sua vida em que adquiriu a deficiência, por um lado, como estando no auge de sua força física e, por outro, como em final de período de transição, ponto chave para o ingresso na vida adulta. A deficiência aparece neste momento como elemento complicador, mas não impeditivo, deste processo de amadurecimento. Trata-se de um elemento estranho que se adere à sua identidade e que leva um tempo para ser assimilado.

Robson faz uma reflexão, comparando o grau de dificuldade de adequação entre os casos de deficiência congênita e aqueles em que ela é adquirida mais tardiamente. Quem tem o maior prejuízo? Quem não tem o que perder porque não "viveu os padrões de normalidade", ou quem já construiu tudo e tem somente que readequar-se? Robson se coloca no meio do caminho. Teve que dar continuidade ao início do processo de constituição de sua vida a partir de um "corte" no andamento "natural" das coisas.

"Na época eu estava com 19 anos. É uma fase assim onde eu estava saindo da adolescência, partindo para virar hominho. E era uma fase muito legal da minha vida, eu estava fazendo exército, fazia faculdade. Eu até, assim, fisicamente eu estava no auge da vida, no auge da idade, maior vitalidade, praticava muito esporte, sempre pratiquei muito esporte. E ai é uma virada, uma virada de $180^{\circ}$. Você sofre o acidente, muda toda sua relação com a vida, com as coisas, com as pessoas, muda a relação familiar, muda totalmente. A relação financeira muda, você gasta o que você tem e o que você não tem na reabilitação. Então, a coisa muda completamente. E é uma fase também esquisita porque você está no meio do caminho, você não acostuma fácil. Imagine uma pessoa que tem uma deficiência congênita, de infância, imagine um. Até sei um pouco dos amigos que eu tenho, das conversas que a gente tem, a coisa fica ... Não que não seja pesado, não que as dificuldades não sejam as mesmas, mas eu acho que a aceitação ela é mais..., ela vem mais lenta, ela tem um tempo maior para ser trabalhada. $O$ parâmetro de normalidade é aquele, não tem um parâmetro de comparação. E quando você sofre um acidente também mais velho, como muitas pessoas que eu já conheci também, você tem pessoas já estruturadas na vida financeiramente, emocionalmente, culturalmente, estão estruturadas já, já tinham o seu trabalho, já tinham o seu, já tinham o seu rumo mais ou menos traçado, a readaptação é fácil. Mas quando você sofre um acidente assim no meio do caminho é esquisito, porque você não se formou em nada, você não fez nada, você está começando a fazer, quer dizer, vöcê tem um parâmetro de comparação do que é, entre aspas "normalidade". E aí pra você se readaptar de novo. ... Então foi um período assim maluquinho, bem maluquinho. Eu passei tranquilamente um ano só fazendo fisioterapia. E aquela coisa meio maluca. Acreditava realmente que eu ia ficar bom, acho que todo mundo... Foi aqui em São Paulo. A sorte é que eu tive uma família muito legal, me deu muito apoio. Teve um lado ruim, que foi o lado do meu pai. Ele não suportou a história, e ele teve um problema de ordem psicológica, e isso afetou profundamente a vida dele, e conseqüentemente a vida da gente, quer dizer, a gente 
percebe que um acidente reflete em toda a família, reflete em toda uma estrutura, não é só na pessoa, as conseqüências são muito mais complicadas, vão se espalhando."

A primeira reação que Robson conta que teve após o acidente, na realidade, consistiu na impossibilidade de viver o presente, de encará-lo. Enquanto esperava que tudo voltasse ao normal, fala do contato com a loucura. A loucura como fuga da realidade imprevista que o desorienta e perturba mais gravemente seu pai. No entanto, para ele, mesmo nesse período de ruptura, foi possível segurar as duas pontas do tempo, o presente e o passado, e manter-se na superfície, mas não fora do fluxo da vida, paralisado.

"E aí o que fiz? Eu fui levando do jeito que dava. A sensação que você tem, é que você foi atropelado por um caminhão, que não sabe nem de onde veio, não sabe qual a chapa, então vocế não sabe aonde vai, o que você faz, se você fica, se você continua, cachorro que caiu da mudança mesmo, né?. Você vai indo do jeito que dá, foi o que fiz. Fiquei muito porralouca, uma fase que eu fiquei muito porralouca, bebia pra cacete, fumei um monte de maconha, que nem porralouca mesmo. Saía pra caramba, lógico que rapidamente adaptei um carro, então comecei a sair, sempre tive muitos amigos. Mas levei a coisa meio na porraloquice mesmo, esperando o tal do dia de ficar bom."

Para Robson, a deficiência não se caracterizou, nem se caracteriza pelos limites à movimentação, até mesmo por causa dos recursos sociais e econômicos que tem à sua disposição para minorar essas dificuldades. Tampouco tem um caráter de isolamento. Parece que se tratou mais de mudança súbita e radical de expectativas e planos de vida.

O retorno ao presente fez com que tivesse que lidar com a deficiência, aonde ela parece-lhe ter mais peso: o constrangimento nas relações interpessoais, fruto de preconceitos e nos atos miúdos do cotidiano.

"Você vive muito de passado e de futuro, aquela coisa assim ... olha, quando eu era campeão disso, campeão daquilo, fazia isso, fazia aquilo e quando eu ficar bom vou fazer isso, aquilo e aquilo outro. Nesse tempo, antes do acidente, eu tinha uma namorada, muito bonita, nós íamos ficar noivos, aquela coisa assim, de garoto besta que pensa em casar, e isso também mudou tudo, a minha relação com ela mudou, quer dizer mudou tudo. Então todo aquele sonho, toda aquela coisa de vida, de tesão de vida, te corta, você não sabe porque, você tem que partir por outro caminho. Aí o que eu fiz. Comecei aos pouquinhos tentando voltar à normalidade de vida. Voltei pra faculdade. Voltar pra faculdade é uma coisa complicada, você sai na rua as pessoas ficam olhando. 
Reencontrar antigos amigos, que ficam com aquele certo... aquela coisa assim ... que não sabem o que fazem, ficam com aquele ... cheio de dedos né? $\mathrm{E}$ encarando o dia a dia né?, aquela coisa de dificuldade do dia a dia, a técnica, escada, degrau e puta que o pariu né?. A gente nunca percebe isso, de repente taí né? Cadeira de rodas, aquela coisa, sempre tem aquela coisa assim. Ah! desculpa de aleijado é muleta. Meu Deus, prefiro morrer do que ficar de cadeira de rodas, de ficar aleijado né? De repente você, o tal do aleijado querendo viver."

O humor, a capacidade de guardar certa distância das vivências dolorosas e rir delas, tomá-las como desafio é uma estratégia de adequação importante, apontada pelo próprio Robson para contrabalançar os momentos depressivos.

Há uma valorização positiva de uma atitude jovial; de otimismo. Tirar o lado bom das coisas, ter a melhor performance, "passar em grande estilo" são demonstrações de apego à vida e a uma vida prazerosa.

"Meu e aí como é que faz? Acho que assim, a coisa mais legal que aconteceu em mim, eu sempre fui meio besta, desde pequeno eu sempre dei risada de tudo, em todas as minhas fases. A fase do exército, estava todo mundo se fodendo, malhando, eu estava lá dando risada. Eu sempre gostei de desafio, eu sempre encarei tudo muito de uma forma muito legal, descontraída. Acho que isso foi minha grande sorte, porque mesmo nos momentos mais dificeis, naqueles momentos que você fica planejando métodos pra se matar (planejei alguns), que eu ia me matar, uma forma indolor, mais eu fui muito covarde, $\ldots$ acho que eu fui muito bundão, não cheguei assim ... sempre gostei muito de viver né?, e acho que esse lado foi o lado legal, eu sempre fui muito sapeca. Então a gente, quando é muito sapeca, a gente se adequa a tudo muito fácil né?, é bem por aí. Acho que eu tenho essa facilidade de adequação, então eu me adaptei a condição de cadeira de rodas. Não é aceitar, diferente de aceitar é até se adaptar, é diferente. Já que tem de passar, vamos passar em grande estilo, é meio por aí."

"E aí o que eu fiz? - Eu fui levando ...", "E aí o que eu fiz? - Comecei aos pouquinhos tentando ...", "Aí o que eu fiz? - Eu fiz ..."

Pela fala de Robson percebe-se que há uma assunção gradativa da direção da própria vida, embora, em nenhum momento tenha surgido uma omissão de sujeito. A vida the apresentava indagações que eram respondidas sempre em primeira pessoa.

Essas respostas também têm grande plasticidade e os caminhos escolhidos são diversos, porém aos poucos vão ocorrendo opções que delimitam um sentido a seus planos. 
"Aí o que eu fiz? Eu fiz PUC-SP. Fiz administração de empresas e fiz direito, porque eu achava que tinha que ser advogado pra defender os deficientes, porque eu achava uma merda todas as injustiças que a gente sofria. Então eu achei que devia ser advogado. Já fazia administração de empresas, aí eu voltei e comecei a fazer direito junto, acumulei duas faculdades juntas né?. Aquela coisa, vou ser advogado e vou mudar este mundo. Porra nenhuma! Não levo o menor jeito pra ser advogado. Então fiz, terminei a faculdade mas não ... terminei aos trancos e barrancos, nunca exerci, mesmo porque nesse meio de caminho eu comecei a trabalhar. Comecei a trabalhar, tive uma oportunidade numa empresa, comecei a trabalhar com computação, então aprendi ... me tornei programador de computador e posteriormente analista, então acabei a faculdade, naqueles trancos e barrancos, nunca fiz exame na ordem, porra nenhuma $e$ ficou por isso mesmo né."

A retomada das relações afetivas para Robson está interligada ao retorno às demais atividades da vida e é causa e conseqüência do processo de aceitação pessoal e social.

O exercício da sexualidade fica prejudicado, dificultado por condições inerentes à deficiência e pelos preconceitos sociais, mas não inviabilizado. A condição de homem e mesmo os valores sociais "machistas" não são apagados. Robson fala de uma diminuição, de uma restrição, fruto de elementos sociais exteriores, imagens vendidas às pessoas, e não de alterações estruturais dessa condição.

"Depois foi isso, trabalhando, comecei a ter umas relações afetivas novamente. Também uma coisa que sempre me ajudou muito, posso dizer que eu tenho uma certa ... que sou privilegiado. Nesse lado, não tive grandes dificuldades afetivas, amorosas, sempre tive gente que gostou de mim, muito, sabe?, sempre tive namoradas. Eu vejo alguns amigos né? deficientes, paraplégicos, que tem a maior dificuldade de relacionamento, não arrumam namoradas, não arrumam uma ..., nunca mais treparam. Essa coisa de nunca mais trepar, pra mim foi tão leve, essa volta, sabe lógico dentro de toda uma nova realidade, difícil de conviver e que vai ser difícil pra sempre, acho que não vai ser fácil nunca, mas foi leve, para mim foi relativamente leve. Nada como você se sentir amado, saber que alguém está te amando, independente de tua condição física, pra te ajudar na tua própria aceitação. Não adianta, você fala: porra sou um cara que me aceito, o caramba, quando na verdade você saí pra rua e as pessoas te rejeitam, quer dizer tem alguma coisa de errado. Alguma coisa está acontecendo, tem alguma coisa de errado. Sem dúvida fica muito mais fácil, quando você tem aceitação, fica muito mais fácil pra você se aceitar. Acho que são coisas que caminham juntas. Você faz todo um trabalho de auto-aceitação, mas também você sabe que tem pessoas que ... né?, e o próprio fato de você enquanto homem né?, pra não falar enquanto machista, enquanto homem mesmo, com aquele conceito todo de que você é meio homem, que a sociedade insiste em colocar, que você é meio homem, que você já não vai fazer uma porrada de coisas, você está conseguindo arrumar namoradas bonitas e que te amam e que você ..., 
porra meu, pera aí, até que eu não tô tão mau assim, sabe? Você começa ver outros lados, lados legais."

Robson reflete que, por outro lado, e dentro do mesmo raciocínio, de que a deficiência não é elemento único e determinante da vida, as relações afetivas e sexuais não são "remédio" para uma condição limitante. Pelo contrário, podem ser extremamente complicadas e agravar um quadro depressivo.

Nos momentos em que está "afundado" pela depressão, a deficiência toma maiores contomos e é usada como causa principal dos problemas. Robson fala que esta compreensão da "relatividade" da deficiência só pode ser percebida em momentos de maior equilíbrio entre a frustração e o prazer.

"Mas com certeza, não foi de imediato não! Acho que mesmo isso acontecendo, eu ainda tinha aquela coisa, de quando eu ficar bom, vai ser melhor, acho que eu fiquei nessa vida mais ou menos uns três ou quatro anos, e eu lembro que lá pelo quinto ano do acidente, eu tive uma namorada. Foi o grande amor da minha vida, a gente se curtiu de montão. E aí por um motivo como outro qualquer, como se eu tivesse andando, ou não andando, ia acontecer, ela largou de mim, e foi numa época que eu estava desempregado, estava ferido; sentimentalmente, foi aonde eu tive minha pior crise, de deficiente, com relação a deficiência, eu realmente quase pirei, achei que eu fosse ficar maluco. Porque querendo ou não, aí que você descarrega tudo, todas as frustrações na deficiência. Porque é assim, eu imagino assim, a vida ela é uma balança, ela é feita de prazer de um lado, frustração do outro, pra você ter uma vida legal, imagino que ela tenha assim um certo equilíbrio entre frustração e prazer e de preferência até o prazer um pouquinho mais que a frustração né? Então esse é o ideal de vida, né?, se você tiver só o prazer também, você não tem parâmetro. O que acontece quando você tem só frustração, começa a ter só frustração na vida, é que a vida vai perdendo o sentido, porque o tesão de vida, você começa a não ter, o tesão de vida, a coisa do prazer pô, você só tem frustração. Pô, pêra aí, isso pira qualquer um, seja qual for, financeiro, físico, e outra coisa, uma coisa que eu cheguei a conclusão também, querendo ou não, o nosso maior prazer, infelizmente, o nosso maior prazer é físico, por mais prazer intelectual que você tenha, prazer profissional, sentimental, cultural, cacete a quatro, prazer mesmo, aquela coisa instintiva, natural, do bicho homem, é o físico. Você sentir um vento na cara, é você comer uma comida boa, é você sentir, se espreguiçar, entendeu, é você gozar, trepar, é o físico, quando você tá frustrado disso, você está inibido de uma série de prazeres físicos ... você tem que ter necessidade de outros prazeres pra suprir isso, e quando isso começa a furar meu, aí é maluco."

Mas no interjogo do prazer e desprazer, qual o peso real da deficiência?

Robson fala de operações que relativizam esse significado. 
"Comecei a assumir isso como estímulo de vida também, esse meu lado pisciano, acho que todo peixe é assim, todo peixe é meio altruísta, aí eu comecei a ter um tesão de trabalhar com isso, porque você começa a ver tanta porta fechada, tanta sacanagem né?, você vai se enchando o saco de ser tratado como ... você perde sua cidadania, como você já deve estar cansada de saber né?, aí você começa a entender também, que cabe a quem tem um pouquinho de estrutura, nós que temos um pouquinho de estrutura, nós que tivemos sorte de ter um pouquinho de educação, de acesso à cultura, de acesso ao lazer, cabe a gente, a gente tem a obrigação de abrir caminho, pra essa grande maioria que não tem essa mesma condição. São essas pessoas que ficam nos faróis e que estão dentro de seus barracos, então eu assumi isso como obrigação.

Nesse tempo que eu trabalhei nessa empresa eu fiz muitos contatos, com pessoas interessantes e importantes, saí dela e abri minha própria empresa, com o objetivo de ser uma empresa de assessoria técnica a deficientes, comecei do nada, comecei eu e mais um cara sabe! Eu paraplégico entrando embaixo de carro, apertando parafuso, achei um tesão, virei mecânico, e sou mecânico até hoje. Sou mecânico até hoje. É legal, eu tenho um certo orgulho em falar isso, que eu tenho hoje capacidade de lidar desde ... de me portar num ambiente dos mais finos e poder conversar com quem quer que seja e ao mesmo tempo ser mecânico, brigar com pião, e apertar parafuso e ir no banco com as mãos cheias de graxa, isso é um grande barato. Então ... é o lance manual e eu acredito assim que é uma puta de uma terapia, é a maior terapia, você manufaturar alguma coisa entendeu? Você fazer alguma coisa com as mãos entendeu?, assim como de mexer mesmo, entendeu? Criar é um barato.

Para o equilíbrio da balança, entre frustração e prazer, é preciso trabalhar, remodelar a massa da deficiência, alterar-lhe o peso, na dimensão em que esta torna-se para Robson mais consistente: no conceito social que conforma a atitude de tristeza e pesar frente a uma pessoa deficiente.

"E assim de repente eu me peguei com um estilo de vida legal, com o objetivo, assumi mesmo, foi coincidentemente quando eu estava assumindo mesmo a minha deficiência, aquela coisa de ser, estou deficiente mesmo, não é sou, estou mesmo, é isso aí, e me gosto assim, sabe então juntou tudo, eu de repente me peguei assumindo, me assumindo muito mais, trabalhando e fazendo com que outras pessoas se assumam. Ganhei um objetivo de vida que é ... hoje eu trabalho, trabalho full time praticamente, com a questão da deficiência, tenho contato com um monte de deficiente. Tenho como objetivo de vida mudar todo um conceito social entendeu? Nessa época que eu comecei a trabalhar com minha empresa, nesse meio tempo que eu saí da "X" e eu peguei, tinha uma grana, fui para a Europa, passei três meses viajando por toda a Europa como cadeirante mochileiro, foi um grande barato, fui de mochila mesmo, de cadeira de rodas, dormindo em albergue, fazendo uma viagem ... de ... entendeu?, com um roteiro mais ou menos traçado mas, nada pré-estabelecido, nada programado, foi uma puta de uma experiência, fiquei três meses, viajei a Europa todinha e foi uma coisa assim que 
Então trabalhar com esse pessoal, às vezes é mais difícil do que trabalhar com a própria sociedade que não é deficiente porque eles são ... não todos lógico, mas a grande maioria são um tanto rancorosos, amargos, entendeu?, altamente compreensivo né?, lógico com tanta frustração, altamente compreensivo, mas também no dia a dia isso tem que mudar!

Em uma posição distante, fala de um comércio de papéis. Òs pessoas deficientes é vendida esta imagem, este papel social que, tal como uma "casca", uma superfície, se adere ao individuo, que passa a viver de forma amarga.

Há uma alusão não tão explícita no discurso de Robson sobre uma outra condição que "atrapalha" o desvestir esse papel: a pobreza.

"Na verdade é assim obviamente pelo meu trabalho, até então atendo um pessoal que tem um nivel aquisitivo um pouco melhor. Vai desde aquele camarada que tem um Santana zero, mas também vai aquele camarada que a família toda juntou e comprou um fusquinha pra ele, velhinho, caindo aos pedaços, que é um cara que também não produz, um cara que não trabalha sabe? poderia dizer que é um cara de poder aquisitivo baixo, procuro atender todo mundo igual, obviamente, dando ... sou super contra assistencialismo, paternalismo, acho que nada tem que ser de graça, mas faço o que eu posso fazer, nesses casos em que as pessoas não tem grana, não tem condições, então eu muitas vezes faço tudo a preço de custo mesmo, a condição de pagamento, enfim, faço o que dá. Mas como a proposta é trabalhar com tudo o que é material técnico para deficiente, eu comecei a trabalhar também com cadeira de rodas, comecei a trabalhar com almofadas, enfim, com acessórios e comecei a atender também as pessoas com baixa renda. E você começa a atender todo mundo e aí você começa a ficar conhecido no mercado. Fica conhecido, as pessoas conhecem a oficina do Robson entendeu, não é nem pelo nome da empresa, é a oficina do Robson, é o Robson entendeu. E é incrível como vai passando de boca em boca né?, E vem gente de todo quanto é lugar, do Brasil inteiro entendeu? E é um grande barato, isso é o maior tesão."

Embora se orgulhe da mobilidade que tem em relacionar-se e conviver em todos os ambientes, parece haver uma dificuldade, uma não intimidade e até um certo constrangimento em lidar com a carência econômica. Esta falta deixa vazios os espaços de apoio para transferir e relativizar o peso da deficiência. Dessa forma, é preciso abdicar temporariamente de condições financeiras melhores para "trabalhar na constituição de um mercado", remodelar e re-significar socialmente a imagem de deficiente, a fim de desvestir-se, ele também, de papel tão incômodo. 
"Então, financeiramente, eu estou longe de estar legal, e estou longe do padrão que eu já tive mesmo depois do acidente, trabalhando eu cheguei a ter salário muito legal e ter um padrão de vida muito bom, eu estou longe ... Eu abri mão disso, por um periodo de tempo, porque eu também quero chegar lá, óbvio, eu não sou bonzinho eu quero juntar o útil ao agradável, eu quero ganhar muita grana, e quero empregar muita gente, quero que a coisa role. Como qualquer empresário quer, entendeu? mas eu abri mão disso por um tempo, investindo num cronograma de empresa mesmo sabe?. E tentando trabalhar com um mercado que na verdade ele é ... ele não é existente ainda, existem pessoas, é um seguimento, mas não é um mercado, ainda não é um mercado potencial, sabe, que você vende, que as pessoas consomem. As pessoas têm a maior resistência em consumir isto ... As pessoas tem a maior resistência em comprar uma cadeira de rodas, elas acham que comprar uma cadeira de rodas é qualquer cadeira de rodas, basta ter quatro rodas e não é isso, entendeu? Então as pessoas não compram este tipo de equipamento, como eles compram uma calça da Forum, o ... sabe? Eles não tem este conceito ainda.

Foi uma família outro dia lá, pra comprar uma cadeira de rodas para a filha, porque ela anda já com muita dificuldade de bengala, de muletas e a cadeira seria uma forma de independência em longas distâncias, lá no Shopping, vai a supermercados. A mãe estava quase chorando porque ia comprar a cadeira de rodas pra filha, e a filha tava delirando, porque a cadeira era toda amarelinha, bonitinha. Ela tava curtinho e a mãe tava achando a maior bosta entendeu?, comprar a cadeira. Você vê que o conceito não mudou em vinte anos, entendeu?. Então o quanto é difícil pra gente, essa questão do estigma, na verdade você não está preso a uma cadeira de rodas, a cadeira de rodas simplesmente ela te auxilia, porque hoje eu sou um cara, que não sou preso à cadeira de todas, nunca fui, se eu quiser, eu pulo da cadeira pra cama, da cama pra ... pulo no mar e nado."

Entender a deficiência como "produção" e, a partir disso, através de linguagem e técnicas de marketing, associar a ela um novo conceito mercadológico faz com que, simultaneamente, Robson possa colocá-la a certa distância de si, relativizar-lhe o peso, torná-la como objeto de trabalho e de desafio e alterar a imagem que os outros e ele mesmo faz de si.

Por esta operação e como estratégia de confirmação experimenta a plasticidade e

leveza da "condição" de deficiente: pode sair da cadeira e mergulhar.

"Eu te falei que eu sou mergulhador? Sou mergulhador, sou o primeiro mergulhador a compor a equipe de Jacques Costeau sabia disso? Um barato né?, eu comecei, eu fui convidado em dezembro de 90 , fui convidado a fazer um ... uma experiência né?, dois mergulhadores e instrutores me convidaram pra tentar adaptar ... fazer um curso pra deficientes e me chamaram pra cobaia. Eu topei, achei do caralho, porque eu sempre gostei de água, sempre gostei de nadar e fui. O curso foi super legal, foi um sucesso, foi dado no mesmo tempo de um curso convencional pra qualquer 
pessoa, eu me tomei mergulhador, comecei a mergulhar com todo mundo, entendeu?, comecei a dar aula pra outros deficientes, ai ficaram sabendo do meu trabalho, e uma associação americana entrou em contato. Entrou em contrato através de uma instrutora do RJ e aí papo vai-papo vem, aquela loucura, me convidaram para fazer um trabalho, junto com a equipe de Jacques Costeau, com mergulhadores de vários países, com deficientes de vários países nas ilhas Fidji, perto da Austrália. Fui fazer um filme, a gente foi fazer um filme com mergulhadores deficientes, então foi a primeira vez que um brasileiro foi no barco de J.C., nós ficamos 20 dias lá. Você imagina, meu, que delírio! Eu lá com a equipe de J.C., mergulhando todos os dias com eles, entendeu? A primeira vez que a bandeira do Brasil tá lá no barco do cara, olha quê do cacete, do cacete!!!

Ao fim desta trajetória de re-significação da condição de deficiente, olha para seu interlocutor, eu, uma pessoa também deficiente. Neste momento, o que ganha relevância na sua percepção, é o grau de minhas limitações. Apressa-se a garantir a mim e a ele que esta possibilidade de viver e ver a deficiência está disponível a todos. Conheceu mergulhadoras deficientes, tão limitadas quanto eu.

"Do cacete mesmo! muito legal. A gente desenvolveu técnicas, onde o deficiente ele ... aquele que é mais comprometido, no teu caso por exemplo, eu não conheço muito bem, mas você tá comprometida de braço, você pode mergulhar, porque você é levada por dois acompanhantes, então a tua viagem, o teu tesão de estar olhando você está ... você vai de passeio mesmo, no início você vai de passeio. Nessa viagem que eu fiz tinha duas meninas, com lesões, altamente comprometidas assim né? Eles mergulhavam, mergulham sempre, quer dizer eles são auxiliados o tempo todo entendeu?, mas até aí sabe! estão lá embaixo d'água vendo tudo. São mergulhadores legal mesmo. Então hoje pra você ter uma idéia, olha o que é que eu faço né?, tenho ... Por isso que eu digo que é tudo ligado a deficiência, tenho oficina, de que hoje é adaptação de carros, cadeiras de rodas, tố trabalhando com cadeiras de rodas nacionais e importadas, almofadas. E a idéia é ter no Brasil, como tem lá fora, um verdadeiro shopinzinho com tudo o que um deficiente possa precisar e a idéia é chegar até outras deficiências, deficiências sensoriais, também a idéia é chegar a isso, ... que é um centro de vida independente, cuja proposta, você sabe também, que é o núcleo de assessoria, tarará ... Estou com o lance do mergulho pra deficiente, tudo com deficiente, então não agüiento mais deficiente, é deficiente o dia inteiro."

Percebe-me como alguém que "conhece", que "sabe" e, portanto, simplesmente inicia frases sobre suas atuações na área.

Toma em consideração, neste momento, que sou uma pessoa deficiente e que também, para mim, a questão da deficiência é objeto de trabalho e de estudo. Constitui-se aí um 
solo comum que origina, por um lado, uma maior aproximação entre Robson e eu e, por outro lado, uma certa "inversão" das formas de relação que ele estabelece com os deficientes, saindo da posição daquele que "trabalha" com essas pessoas.

Quando o campo da nossa relação salta à superficie e torna-se objeto da conversa, o objetivo de "convencer-me" da possibilidade irrestrita da aplicabilidade desse estilo de vida, desse novo "conceito" fica deslocado e, Robson, é re-enviado ao inicio de seu discurso, em uma tentativa de redefinir-se, mas agora com outra indagação a ser respondida acerca de si próprio.

"Que mais? Sou filho único, não sou veado, todo mundo fala que filho único é veado. Ah! filho único é veadinho, é mimadinho, não sei o quê. Atesto que não."

No momento em que a deficiência é ultrapassada, deslocada, depositada nos outros e, especificamente, em mim, o fio narrativo é retomado por Robson a partir do contexto familiar e relacionado ao aspecto sexual: "sou filho único, não sou veado".

Em relação à família, a sua referência dá-se por uma afirmação e o coloca como especificidade, como individualidade, fillho único.

A essa condição associa uma conseqüência que nega: não é veado. Parece haver uma associação entre ser objeto único, alvo de cuidados e atenções da família a uma fragilidade que se oporia à condição de homem, de macho.

"Hoje moro com minha mãe, morei uma época com, já morei fora de casa alguma vezes, morei com tio, fui casado três vezes, eu brinco que fui casado três vezes, eu nunca casei né?, nunca casei, mas já me separei três vezes. Eu já morei fora, no caso voltei, moro hoje com minha mãe, meu pai voltou pra casa, depois de anos também internado, devido aquele problema né?, ele voltou pra casa. Também ele já tem uma certa idade, então ele hoje é, ele é também no nível de esclerose assim né?, ele voltou há pouco tempo pra casa, também foi uma adaptação difícil, porque a gente estava super acostumado, assim a ter uma série de banalidades e tal, é difícil essa adequação né?. A gente ficou dez anos afastados. Dez anos, ele morando fora de casa, e brigas, esse tipo de coisas, então foi meio complicadinho. Faz um ano que ele voltou, está lá, tá indo lá, ficou quase 11 anos fora de casa, foi meio complicado mas é isso, moro mas é legal, tenho minha individualidade, sou preservado, minha casa é tranquuila. Sou síndico de 
meu prédio. Ah! atenção eu faço mais essa: sou síndico do prédio. Mais esse saco, adero me foder mesmo. Adoro me foder mesmo."

Para atestar a condição de homem, fala da sua independência e, portanto, da possibilidade de morar com a mãe ou morar fora, inclusive com outras mulheres. Mesmo morando com a mãe, deixa claro em que condições. Apesar da volta do pai ter trazido "dificuldades", o seu espaço na casa não é alterado em função disto. O pai voltou, mas numa condição de dependência. As dificuldades relacionam-se mais aos aspectos emocionais, mais pesados, que este retorno recoloca, apesar das tentativas de minorar o problema, "está complicadinho".

O lugar de "homem" da casa é expresso em uma relação com uma comunidade externa: é síndico do prédio. A figura de homem está ligada à gerência do espaço público e a independência física, mantida apesar da deficiência, é pré-requisito para isto.

"Moro em S..., pela primeira vez estou trabalhando perto de casa, minha oficina é pertíssimo de casa, eu sempre trabalhei longe pra caramba, que é um saco. Mas é assim, trabalho perto de casa, me viro bem, assim é legal. Minha deficiência não me compromete a nível de dependência, me viro relativamente legal."

Outro aspecto que confirma sua masculinidade é a manutenção da possibilidade de atrair namoradas, mesmo após a deficiência. Na realidade, fala até de um "aprofundamento" dessas relações, atribuído a um papel de seleção daquelas que superaram preconceitos e também ao amadurecimento pela idade. Essas relações são mais profundas porque ligam sexo e convivência, sem a regulamentação das normas e instituições sociais como o casamento.

"Que nem eu tava te falando. Eu ... graças a Deus, graças a Deus mesmo. Dizem que eu sou bonitinho, eu nunca tive dificuldade com namorada, eu tive namoradas, lógico que não é mais a mesma coisa, não é mais ... existe o preconceito das pessoas mesmo, lógico, mas porém por um lado eu acho que é assim tem até seu lado positivo, porque na maioria das vezes as pessoas que se aproximam da gente são pessoas que no mínimo já passaram por um estágio de preconceito, elas já ultrapassaram esse estágio, então no mínimo são pessoas interessantes. São interessantes, não são pessoas tão superficiais assim entendeu?, então é um lado muito positivo. E aí as minhas 
relações sempre ficam, sempre são relações fortes, nunca são relações assim muito bestas entendeu?. Sempre foi uma coisa assim erótica, mais legal. Eu sou super contra casamento, principalmente depois que eu fiz direito, sou super contra casamento, acho que casamento é um saco, é uma instituição falida, não a família, a família não - eu acho que a familia homem, mulher, filhos, pai, mãe -, eu acho que é do caralho e é por aí sempre vai ser por ai, mas o casamento mesmo, enquanto instituição ... Antes do acidente eu não era porra nenhuma porque eu só tinha 19 anos e ia casar, eu era bem à favor mesmo, mas depois eu ... Eu sou contra, eu acho que é uma instituição falida mesmo, essa coisa do papel. Acho que o papel na verdade não vale porra nenhuma, acho que quando a gente tem uma coerência de vida, você fica com alguém porque você quer né?, você não compra essa pessoa, você não adquire, então você não precisa de certificado de garantia, nem de prova, e os ditos populares são até certos né? Porque se fosse bom não precisava de testemunhas, então duas pessoas têm que ficar juntas enquanto elas querem, quando elas não querem elas não tểm que ficar mais juntas e elas têm que ter coerência suficiente pra que os frutos dessa relação, sejam eles materiais ou humanos né?, os filhos tal, sejam administrados por eles, mesmo após a relação se tornar diferente, porque acho que a relação não acaba, ela se torna diferente né?, nem que se tornem inimigos. Mas é uma relação, uma relação de inimizade, mas é uma relação, então eu sou contra."

Como homem, amadurecido pela idade, pode viver relações afetivas não banais,

de uma forma não convencional, devido à ausência de preconceitos e a partir de uma crítica social que não tinha na juventude.

"Eu tive a primeira namorada, que foi assim minha mulher, primeira namorada que se tornou minha mulher, foi uma loira lindona, muito bonita assim, a gente tinha um lance muito legal, um ano juntos, moramos um ano juntos e acabou por ciúmes, por incrível que pareça! todo mundo acha isso incrível, por parte dela. Eu sempre tive problemas de ciúmes por parte das minhas companheiras entendeu?. Nessa época eu tocava. Eu te falei que eu toquei? É, eu era músico. Eu já fui músico, é antes do acidente eu era músico né? Eu era professor de música, tocava e depois do acidente, depois que eu saí dessa empresa que eu trabalhava como programador de computadores, eu voltei pra área de publicidade, então eu trabalhei um tempo em agência de propaganda, como redator, e aí depois voltei pra música mesmo, então tocava em bares à noite, tinha uma banda cover, rock cover e fazia produção musical durante o dia ... esse tipo de coisa, então e foi justamente nessa época que nós moramos juntos. Era difícil mesmo pra ela, porque eu trabalhava à noite e era complicado, rolava uma relação de ciúmes meio maluca, aí não deu certo, foi uma coisa meio chata, aí não deu certo. Aí depois tive várias namoradas né?, mas essa foi uma mulher, mulher. Depois eu tive a G., que foi essa menina que eu te falei que eu fui apaixonado e que me largou. Nós tivemos uma relação de quatro anos, foram quatro anos, entre largadas e deslargadas, desde a primeira abandonada que ela me deu, até a última, nós namoramos quatro anos ao todo, de relação, foram quatro anos, desses quatro anos, nós moramos acho que um ano e pouco juntos. Então eu chamo de namorido, mistura de namorado com marido. Na verdade, depois de uma certa idade, hoje em dia as relações são por aí, não é diferente. E depois dela, tive ... minha outra mulher foi a A., outra A. Teve a A. 1 e a A. 2 que também a gente ficou um ano, um ano e pouco juntos, a gente, desse um 
ano e pouco, a gente morou seis meses. Foram as minhas "namoridas", o resto foram "namoridas" mas não moramos juntos, não chegamos a morar juntos."

Ao narrar as histórias de seus relacionamentos, fala que os rompimentos deramse ora por iniciativa de um, ora de outro e por razões que não guardam nenhuma vinculação com a deficiência.

Após afastar a questão da deficiência, das experiências reais vividas, inicia uma reflexão acerca da possibilidade/adequação de uma relação sexual entre um homem e uma mulher deficiente. Essa associação pode ter surgido com a evocação do nome Ana e a consideração da minha condição de mulher deficiente, além do "tema" da pesquisa.

"Eu nunca namorei uma mulher deficiente. Eu sempre fui preconceituoso, verdade! E gozado isso né?, eu brinco com o $\mathrm{M}$. tal, eu sempre tive preconceito, verdade, verdade! Não preconceito com a pessoa, mas assim preconceito com a situação assim eu até brinco que é assim: Era muita desgraça para uma família só, né? E por um outro lado, eu sempre tive um pouco de rejeição porque assim na verdade eu nunca me senti atraído por nenhuma mulher deficiente ... e depois é meio que ... reforça aquele estágio de deficiente com deficiente, preto com preto, gente feia com gente feia, japonês com japonês."

Essa reflexão inicia-se pelo argumento de que o relacionamento entre homem e mulher deficientes concretiza o estigma. Contudo, a partir da lembrança de um relacionamento que levou a cabo com uma mulher deficiente e, talvez por uma atitude condescendente e cavalheiresca comigo, fala dessa relação como possível, em principio. Entretanto, essa possibilidade é restringida por aspectos práticos, logo independentes de uma vontade, de uma escolha.

"Agora isso foi pro brejo naquele Seminário, porque no Seminário eu conheci uma mulher! Que você deve ter visto lá, aquele dia que nós estávamos conversando. Uma loira, bonita pra caramba, simpática pra burro, e ela tem um quadro de tetraplegia fodido, e quando eu a conheci nossa! eu chapei nela, gostei dela, ela me atraiu muito e nós tivemos um caso lá no Seminário. Ficamos juntos, tivemos um caso, foi engraçado porque esse maluco ai, o P., transou com a gente. Isso agora eu vou explicar, transou com a gente é modo de dizer, porque é assim, tecnicamente. É complicado né?, porque ela é tetraplégica, não conseguia fazer nada sozinha, eu paraplégico, conseguia ajudar 
em termos, em termos né?. Então eu escalei ele pra pôr ela na cama pra mim. Ele pôs ela na cama pra mim entendeu? A gente transou, tinha uma relação muito legal, uma experiência legal, e porque foi a primeira mulher que me atraiu, primeira deficiente que me atraiu. Agora, tecnicamente, realmente, complicado, complicadíssimo entendeu, complicadíssimo, e reforça a minha teoria, que é muita desgraça pra uma família só. Muita desgraça, a não ser que tivesse um amor muito grande, e muita grana, e muita assessoria, porque fora disso meu! Mesmo assim, eu fico imaginando uma paraplégica, tecnicamente é complicado, é complicado, alguém tem que mexer nessa história, no alto da poupança alguém tem que mexer meu! sabe! isso é minha verdade agora né?, pode ser que mude! Mas é minha verdade agora, tecnicamente é complicado, não que não seja possível, não existir amor, e que, relacionamento mas se você analisar pelo lado prático e técnico é complicado pra cacete né?, então, nada como você ter uma pessoa né?, que possa continuar a ser ativa, pra te auxiliar naquilo que você é menos ativo, então isso eu acho ... sabe? é real, é real, não é gozação, é real, não é papo de falar ah! você tem preconceito, não é não, tecnicamente é complicado, acho que uma relação entre um deficiente e um não deficiente é fácil, é fácil, uma relação entre dois deficientes é bem mais complicado, é mais complicado."

Essa atitude cavalheiresca e a necessidade de guardar certa distância da questão da deficiência estão na base das considerações que Robson passa a tecer acerca desse terceiro abstraído e desconhecido: a mulher deficiente. Em geral, coloca a mulher como uma pessoa mais "aprimorada" frente à rudeza masculina e, por isso, a mulher deficiente, mais privada e carente, em virtude destes aspectos culturais. Embora, saliente que a concretude do problema, as maiores dificuldades, estariam nas limitações (relativas, é verdade, mas não impalpáveis) do desempenho sexual por parte do homem deficiente.

Por fim, para encerrar este assunto, reitera a primeira afirmação relativizando-a:

"Agora, realmente não tive muitas atrações por mulheres deficientes, só tive por essa ..."

"Agora é o que eu tô dizendo mas não que ... é como eu te falei, essa menina do Seminário, pô é uma mulher do caralho, bonita, ativa, ela é médica, chefe de radiologia de três hospitais, ela é do cacete, e que sofre uma solidão fodida, porque o preconceito do homem com relação a mulher deficiente é maior, do que o preconceito de mulher normal, vamos dizer assim normal entre aspas, com o homem deficiente. A mulher por natureza ela é muito mais sensivel, ela é muito mais ... ela vai muito mais pela emoção, pelo sentimento, do que pela parte física né?, naturalmente já é assim, culturalmente também né?, nós somos uns .../exatamente, a nossa cultura machista já é assim, a atração do homem pela mulher, já é mais sexual mesmo. Não que não tenham outras atrações, lógico que tem, mas ela ... tem toda uma questão cultural, da mulher ter que ser bonita, gostosa, aquela coisa toda né?, o preconceito do homem é muito maior, eu acho isso, e assim em conversas com amigos deficientes tal, sente-se isso, a solidão de mulher deficiente é muito maior, do que do homem deficiente, mesmo que tecnicamente ao contrário seja melhor né?, porque pô o homem carregar a mulher deficiente é muito 
mais fácil né?, até no ato sexual é mais fácil um homem normal com a mulher deficiente, porque você não tem a relação, ereção em jogo, né?, vocế não tem uma série de relações em jogo, masculino, então pra mulher é muito mais fácil, o próprio fato de poder engravidar, de toda essa relação que no homem já é mais difícil. A paternidade, principalmente nos lesados medulares né?, mais por um lado a parte emotiva, emocional de aceitação da mulher é muito melhor. Não sei se a mulher é muito mais maternal, ou se ela é mais sentimento eu não sei! ou se ela é mais inteligente, ou se ela é mais despreendida, ou se ela é mais eu não sei, a mulher é um bicho, entendeu que nesse ponto é do caralho entendeu. Em outros pontos também, mas nesse eu acho que a mulher é muito mais bem resolvida que a maioria dos homens. Apesar de eu já ter conhecido vários casais onde a mulher é deficiente e o homem não. Também é do cacete, se dão super bem, a mulher é super bem amada e tudo o mais. Mas numa regra geral né?, via de regra é o contrário que a gente vê mais né?. E eu só consigo entender por aí, que é esse lado dia a dia, de como a mulher gosta né?, ela gosta de uma maneira mais difusa mesmo, envolve muito mais coisas né?, ela foi muito mais condicionada a isso, mais educada a isso. Agora realmente eu não tive muitas atrações por mulheres deficientes não, só tive por essa que é uma gatona né?"

Objetivando reconduzir-me a um lugar mais confortável na relação, retoma sua fala para uma pessoa deficiente que pode constituir-se em um auxílio para a concretização de seu objetivo de "trabalhar" o conceito de deficiente. enuncia aí uma dúvida atual acerca da melhor estratégia para manter-se convencido da possibilidade de viver "esse estilo de vida". Experimentá-lo concretamente mudando-se para uma outra realidade, ou através do trabalho de convencimento dos outros?

"Ah! tem uma coisa que eu queria falar, isso é importante, uma grande dúvida na minha vida agora.

Quando eu fui fazer essa viagem com a equipe de Jacques Costeau, o projeto FIDJ, que na verdade foi essa história, a gente foi pra Fidji fazer um filme com mergulhadores deficientes, que na verdade, o filme sobre a ecologia da região, preservação dos corais, e tinham deficientes de vários países e tal, e nessa viagem, eu conheci uma menina, a M., uma americana instrutora de mergulho, não deficiente né?. $\mathrm{E}$ a gente, nós nos apaixonamos nessa viagem né?, quer dizer mais ou menos né?, paixãozinha, paixão de navio, e na volta né?, nós ficamos em Los Angeles, ela mora em Los Angeles. A gente, porra assim, bateu a maior vontade de morar lá, de ir embora do Brasil, por toda uma conjuntura, lá é tudo estruturado, eu passei dez dias lá em Los Angeles, nesse intervalo de viagem, sozinho, em hotel adaptado, andei de ônibus, andando a cidade inteira sozinho, de cadeira, quer dizer em todos os lugares acessíveis né?, e ainda vivendo uns dias de namoro, gostoso, com essa menina né?, e eu só não fui embora porque esse projeto de vida que eu tenho aqui, pode parecer maior demagogia né? porque esse objetivo de vida que eu tenho aqui, de ficar aqui no Brasil, e trabalhar essa questão de conceito, é muito forte, é muito forte, vai fazer um ano que isso aconteceu, e quando eu voltei, eu falei assim: Eu vou largar tudo, eu vou embora, vou pra lá, caso com a M., viro americano e moro num país onde eu sou tratado como 
gente! Sabe! e as minhas frustrações vão diminuir muito, tanto no lado físico, quanto no lado até econômico, que lá é um lugar legal, vou estar como americano, uma série de coisas, e pintou até essa idéia mesmo, até ela cogitou essa idéia mesmo, sabe?, pintou assim, e até falei com ela no telefone esses dias atrás, e, lógico que depois desse tempo todo, já deu uma esfriadona, mas ficou aquela, ficou pelo menos aquela ilusãozinha no ar né?, e eu só não fui embora, por causa disso sabe! por querer fazer uma história de fazer uma história assim ó, Robson nasceu, viveu, morreu, mas fez uma história, sabe! é meio maluco né?, é meio maluco mais eu quero fazer uma história, sabe?, eu quero que eu quero ficar famoso, "famoso", não é ficar famoso tietagem! entendeu, eu quero ficar com poder suficiente pra poder acessar a mídia, porque só mudando a mídia, só a gente trabalhando a nível de mídia a gente consegue trabalhar a nível de conceito, e aí as coisas rolam entendeu. Não adianta nada você ter, milhões de normas, milhões de regras, e uma legislação obrigando, quando o conceito ainda é estigmatizado negativamente. Não adianta, as pessoas nunca vão fazer adaptação, elas só vão fazer por imposição né?, e nunca vai fluir naturalmente, e eu quero trabalhar muito neste sentido, mesmo, mesmo, as vezes eu sinto a maior falta do lado econômico. Pesa, sabe! estou com 31 anos, às vezes eu fico pensando, até quando, você tem gastos, a gente tem gastos mais pesados entendeu, daqui a pouco, se eu resolver morar com alguém, montar uma casa mesmo, e aí né?, mas eu ainda tô insistindo por um tempo nesse lado. Não sei qual que é, não sei o que vai dar, mas tô insistindo, vou insistir até onde der sabe! Esse lado de mudar conceito e pelo menos no meio onde eu freqüento, eu consigo fazer isso que já é legal, no meu trabalho eu consigo fazer isso, porque cada cliente que sai de lá, sai diferente com certeza, e se há aqueles que não saem, é porque não entenderam nada mesmo, paciência também, mas eu quero fazer isso também de uma forma mais geral. Sabe! uma coisa maior, por isso essa história de chamar $\mathrm{M}$., chamar o $\mathrm{B}$, o $\mathrm{C}$. porque são pessoas que podem me ajudar a trabalhar a nível de mídia sabe! entendeu, por isso a idéia de ... não está descartada a idéia de um trabalho desses junto ao governo do Estado."

Na verdade, essa dúvida não é real. Para viver esse novo conceito de deficiente é preciso experimentar um certo lugar de destaque, de modelo, sair do anonimato. É preciso retomar as expectativas e sonhos do adolescente, recolocar-se no caminho interditado temporariamente pela deficiência, lutar pelo ideal jovem do líder, do inovador, daquele que gera transformações sociais.

\subsection{ESTAGNAÇÃO: A IMOBILIDADE DO DESEJO A História de Márcio}

Márcio é um homem de 32 anos, portador de seqüelas de poliomielite. Utiliza-se de cadeira de rodas, movimentando-a com certa dificuldade. Eu o conheci em um cruzamento no caminho que habitualmente faço para o trabalho. Ele vende fichas telefônicas no farol. 
Márcio inicia sua história com um "histórico" da Casa onde mora atualmente. A história da Casa começa fora daqui, em outro país, começa na Inglaterra. Apesar desse início estrangeiro, alheio, Márcio fala que mesmo a organização inglesa não dá conta dos "nossos problemas".

"A casa onde eu moro é ligada a uma organização inglesa. A organização é inglesa, mas os problemas são nossos. Justamente através dessa Casa eu estive na Inglaterra em 1989. A Casa chama-se Cheshire Home. É um lar que tem em toda a Inglaterra. Começou na Inglaterra, hoje tem no mundo inteiro. E foi um capitão, um herói de guerra, (estou aproveitando e contando o histórico), um herói de guerra da Inglaterra que queria encontrar um lugar para esse amigo, uma casa. $\mathrm{O}$ amigo só tinha problema de mutilação. Ele não conseguiu encontrar, andou a Inglaterra toda e não conseguiu encontrar. Aí ele falou: 'Não, isso não podia acontecer, como a guerra foi uma coisa no mundo inteiro, muitas pessoas vão passar por várias dificuldades'. $\mathrm{E}$, então ele pensando, pensando, um dia falou: 'O jeito é usar minha posição e fazer alguma coisa para os outros.' Inclusive, o primeiro lar foi a própria casa dele, você entendeu? Transformou num tipo de um abrigo para pessoas deficientes. E aí foi melhorando. Depois chegou uma época, depois de vários anos dessa casa formada, foi fazer uma outra casa para outro tipo de deficiente. E assim foi fazendo. Hoje, só na Inglaterra, tem mais de 200 casas e o patrono deles na Inglaterra é a Rainha Elizabeth, quer dizer, eles estão super bem de vida lá."

A realidade deles é diferente, não porque tenham outro nível econômico, cultural, mas sim; porque dispõem de um protetor especial, de uma "madrinha", a rainha da Inglaterra.

A tradução brasileira dessa estória é bem menos maravilhosa. A Casa aparece como única opção de moradia para quem saiu de Minas, deficiente.

"Agora, aqui em São Paulo, só tem esse lar, o que se torna um Lar Residência. Coisa que você não consegue encontrar em nenhum lugar em São Paulo. Então realmente é um lar. Eles querem ter uma filosofia. Essa filosofia você tem que viver, conviver com todos, no sentido familiar. Claro que acontece vários tipos de coisas, brigas ... Então é gostoso, é isso aí ... Aqui em São Paulo é só essa casa.

Agora, eu, Márcio não pretendia ficar naquela casa, como estava ficando. Porque eu sou de Minas. Desde que eu tive paralisia infantil, quando eu tinha três meses de idade, então eu vim para São Paulo. Uma mulher, que hoje é minha madrinha, me trouxe para São Paulo. Me trouxe, fiz todos os tratamentos. Mas só que essa mulher não queria que eu voltasse para Minas. Queria que fizesse todos os tratamentos que deveria fazer aqui em São Paulo para depois, se eu melhorasse, voltasse para Minas 
Gerais. Mas não deu, ou seja, tudo que deveria dar já foi feito. Eu peguei a paralisia mesmo, fiz mais de 30 operações, quer dizer, que tudo que tinha para acontecer já aconteceu. Só que nessa eu vivi sempre em São Paulo, num centro de reabilitação, no Lar Escola, morei lá e tudo. Cresci lá, estudei lá, trabalhei e só saí de lá com 23 anos. Trabalhei na parte de administração lá dentro, mas era registrado, tudo legal."

Embora mantendo uma ligação com o lugar onde nasceu, porque, afinal, ainda é de Minas, sua madrinha, misto de fada boa e fada má, o expatriou. Só que a deficiência, razão da saída de seu Estado de origem, não pode ser superada, é uma nova condição, permanente. Essa condição gera confinamento.

No espaço de tempo entre o Lar Escola e o atual Lar Residência, Márcio vivenciou outras moradias.

"Saindo de lá fui para Barretos. Fiquei em Barretos 15 dias. Não gostei de Barretos, e nem dava para gostar, é uma entidade de André Luiz, mas muito baixa. Naquela situação tinha deficiente misturado com velhos, misturados com retardados, com loucos. Tinha uma ala de mulheres, uma creche e a gente era muito vigiado dentro da instituição. Eu não podia ficar lá dentro. Minha cabeça era outra, meu modo de agir era outro, de ver as coisas. Então acho que eles falaram: 'Esse cara vai ser problema.' Eles descobriram meu telefone em Minas, ligaram para a minha mãe dizendo que eu queria me matar, que ela tinha que me aceitar. Minha mãe nunca não quis me aceitar, ela sempre quis que eu estivesse com ela. Então tudo isso aconteceu ... Então eu fui para Minas. Fiquei lá em Minas."

Cada lugar, identificado com uma instituição peculiar, é um espaço-tempo na sua história. A Inglaterra é o reino das op̧̧ões (mais de 200 casas), das madrinhas reais e dos heróis de guerra, é o espaço do anseio e sonho de nobreza. São Paulo tem três tempos, o momento do Lar Escola, o momento da estabilização, do Lar Residência, e o da Rua, percurso entre eles. Minas é o espaço parado da família, pousada, refúgio, tempo de espera. E, Barretos, São Paulo degradado, entidade que congrega marginais, velhos, loucos, retardados, mulheres e crianças abandonadas. Inglaterra e Barretos, aspectos extremos da vida de Márcio. Mas no caminho entre o reino das fábulas e a realidade crua da miséria e do abandono há muitas outras estações. 
"Lá em Minas a gente é pobre. Tem telefone dentro de casa, tem todas essas coisinhas, mas tudo conseguido na luta da mamãe.

Mas, eu me sentindo um cara super estranho. Nunca tinha convivido com a minha família. Só conhecia minha mãe, minha irmã também estranha. Também 23 anos ... Mas tudo bem, eu disse: 'Vamos tentar'. De fato eu tentei. Dormia às 3 horas da manhã, acordava todo dia às 11 ou 12 horas.

Quando eu acordava, ia direto para a televisão, ligar o rádio ou ficar no telefone o dia todo falando com as pessoas. Só bem coisas de quem não tem nada para fazer. Fora as encheções da mamãe: 'Você só faz isso, ou aquilo ...' Até parece que eu queria fazer só aquilo. Mas, tudo bem. Com o passar do tempo vou ter que me adaptar mesmo, vou procurar ... Tinha uns amigos meus lá desde pequeno, a gente se dava bem, mas os amigos tinham que levar a vida deles, tinham que fazer as coisas deles. E a gente parado lá! Puxa vida, que raio de vida que eu levo! Mas tudo bem. Sabe, quando você de repente não quer fazer nada, quer ficar naquela vizinha, tá bom ficar. Com o passar do tempo aquilo vai enchendo também, Então eu comecei a pensar: 'Eu trabalhei de administração, então eu tenho que fazer alguma coisa'. Mas sem contar com essa realidade lá fora. É difícil as pessoas abrirem a porta para você, super difícil. Essa não, com meu otimismo lá vou eu ligar para um, ligar para outro, vou ligar para a prefeitura, falo com um homem, ligo para o hospital, converso com os caras de lá, faço ficha aqui e ali. Mas só fica na promessa: 'Deixa a ficha e vamos ver se chama'. Você sai para passear com um amigo quando dá oportunidade. Aí, de repente aquelas coisas em casa ... Em casa tudo parado. A mãe me entende: 'Coitado também não tem carro, vai fazer o que?' Aquela vizinha de pobre mesmo. Mas aí foi passando o primeiro ano, o segundo foi tudo repetido do primeiro ano. Mas o que motivou sair de Minas foi na hora, lá em casa, que eu queria comprar uma bala, uma balinha. Eu tinha na época, mais de oito anos*, 30 cruzeiros para comprar a bala e o rapaz volta e fala que não dava para comprar a bala.

Aquilo me deixou tão revoltado, fiquei tão furioso da vida. Falei: 'Isso não é vida!' Mais, tudo bem. Dei uns dias, comecei a falar para minha mãe: 'Mãe eu vou embora', -'Vai para onde menino?' -'Vou para São Paulo.' -'Vai fazer o que em São Paulo? Quem vai fazer as coisas para você?' -'Ah mãe!, não esquenta não. Vou ligar para um amigo. Chega lá, eu me hospedo na casa desse amigo, fico uns dias e depois a gente vai levando a vida'.

Mas tudo isso era história para minha mãe não ficar preocupada. Aí, eu me lembro bem, foi no começo, uma segunda-feira ela saiu para trabalhar ... Ah, todos esses dias eu passava sozinho. Ela saia para trabalhar, eu ficava só dentro de casa. A vizinha me dava comida, a parte de banheiro era mais fácil, eu me virava sozinho. Eu falei: 'Deixa eu falar com um amigo. Quanto você tem de dinheiro, agora, já?' -'Tudo bem. Por que?' -'Porque eu quero ir embora. Eu vou embora.' -'Vai embora?' -'Vou batalhar a vida lá, em São Paulo, aqui não acontece nada! Eu só durmo, como. Já procurei trabalho, procurei várias pessoas, mas elas não querem fazer nada. Eu não quero mais levar essa vida.' O amigo com muita relutância falou: 'Tá bom'. Ligamos para a rodoviária: 'Quanto tá a passagem?' -'Tá 7.000,00.'

Comecei a falar com outros amigos até arrecadar mais dinheiro para não chegar a São Paulo sem nada, acho que conseguimos uns $22.000,00$ fora a passagem. Aí eu

\footnotetext{
* Trata-se de uma referéncia ao tempo transcorrido - mais de 8 anos atrás -, e náo à idade como ambiguamente transparece.
} 
falei para minha mãe. Quando ela chegou a passagem já estava comprada. Mãe quero falar com você!' -'Que foi?' -' Vou embora. A passagem, já está aqui e o ônibus sai às 11 e meia da noite. Vamos arrumar as malas logo'. Ela viu que era sério e arrumei tudo, ela disse: -'Se é assim que você quer' ... despedi dos amigos, e vim para São Paulo. A minha mentalidade não era vir exclusivamente para São Paulo. Mas eu falei: 'Eu tinha entre Rio de Janeiro e São Paulo'. Mas eu falei: 'Em São Paulo eu conheço alguém e no Rio de Janeiro não conheço ninguém é melhor não arriscar o Rio de Janeiro. Vou arriscar São Paulo mesmo'. Eu vim para cá com o intuito de eu conseguir as coisas para mim mesmo, sem ficar na dependência. Apesar de eu conhecer, até pessoas, mais pra ligar só na última hora mesmo, só tipo se acontece alguma coisa, qualquer acidente, alguma coisa, contrário, eu não devia ligar para ninguém."

De volta a Minas, tenta se adaptar, tenta se enraizar de novo, mas é um estrangeiro, é de Minas, nasceu em Minas, mas viveu, cresceu, estudou, trabalhou no Lar Escola durante 23 anos.

Apesar de ter efetivado inúmeras tentativas de se inserir como adulto produtivo, no mundo do trabalho, a estagnação da situação o leva de volta à condição de dependência própria da infância, não pôde nem mesmo comprar uma bala.

Esse momento, com características da adolescência, isto é de ambivalência entre o mundo adulto e infantil, o fará inconformar-se com a repetição monótona dos dias e o lançará na viagem, travessia de sua vida. É preciso viajar, sair de Minas, encarar a aventura das ruas de São Paulo.

"Eu cheguei em São Paulo no outro dia às 6 horas da manhã. Vi várias coisas que eu já conhecia. Adoro São Paulo. Também, quando chegava o fim de semana lá em Minas Gerais, eu queria morrer, porque era parado de tudo, sem movimento, sem nada, eu queria morrer. Então cheguei em São Paulo, aquele mundaréu de gente e eu sozinho. 'E agora?', eu pensei. 'Como é que vai ser?' Tudo bem. Mas o dinheiro desapareceu, o dinheiro desapareceu.

Você tem vontade de comer uma coisinha, você compra, você quer, você compra. Então, de repente quando eu olho para mim, só estou com cinco mil, cinco mil. Nas duas primeiras noites eu não dormi em lugar nenhum. Não dormi porque no primeiro dia eu fiquei na rodoviária só esquematizando o que eu ia fazer. Quer dizer, dava fome eu ia lá comprava uma coisinha, comia e voltava para a meditação. Vamos lá. Em primeiro lugar, vamos procurar um lugar para dormir, mas como era muito tarde, no outro dia eu começo a procurar. Na primeira noite dormi na rodoviária mesmo. Novo dia, logo em seguida, já peguei o metrô. Fiquei andando de metrô o dia todo, pra cima e pra baixo, pra cima e pra baixo.

Vou fazer o quê? Pára numa estação, saia ficava vendo ... vou perguntar para as pessoas onde fica um hotel, qualquer coisa assim. Tudo na esperança. E isso foi o dia 
todo. Só sei que terminou o dia, veio a noite, quando foi umas nove horas da noite, eu tinha cinqüenta cruzeiros. Só estava com cinqüenta cruzeiros no bolso. E agora? Bom, de repente, quando eu sai do metrô Ana Rosa, quando eu olho do outro lado, um hotel, a menos de 30 metros de distância. Falei: 'não acredito! Só falta o cara agora deixar eu ficar nesse hotel'. Cheguei, falei com o rapaz que estava lá, com um outro rapaz. Falou: 'Tudo bem'. E eu falei: 'E aí quanto é a diária? -'Cinqüenta cruzeiros'. Os meus últimos cinqüenta. -'Toma, leva!'. Tudo bem.

Naquele dia tomei um banho no hotel, caí na cama e desmaiei. No outro dia, era cinco horas da manhã, já estava acordado. Me arrumei, tudo direitinho e fui pro metrô. Vamos agora pro centro da cidade que lá é bem movimentado. Vamos lá. Cheguei no centro, começo a pesquisar também o que eu vou fazer agora. Eu não tenho nenhum dinheiro pra nada, não tinha mais dinheiro. 'E aí Márcio, vai fazer o que?' Pensa dali, pensa daqui ... Vejo as pessoas passando, procurava na multidão uma luz, um clic qualquer. Mas sabe, quando você já sabia a resposta, mas não queria aceitar aquilo de jeito nenhum? Então, eu já sabia o que eu tinha que fazer. Sabia que eu tinha que pedir pra poder levantar uma graninha, pra poder começar. Vai vender bala, vai fazer qualquer coisa mas eu queria fazer, não queria pedir de jeito nenhum.

Ficava rodando daqui pra lá... Tudo bem. Depois de muita luta mental: 'Vou pedir.' Encostei a cadeira num lugar que eu achava mais movimentado e comecei. Passava os caras e eu ia pedir, a voz não saia. Não, agora eu vou, agora eu vou. Passava um e nada. A voz não saia. Aquela coisa ficou duas, três horas, eu criando coragem para poder pedir, sabe. Mas puxa Márcio, o que adianta, você não vai conseguir de outra maneira. Sabe aquela luta mesmo! Seja o que Deus quiser. Passou um moço, eu disse: 'Moço, o senhor não me daria um trocadinho?' Que estória eu vou contar para esse cara? Mas não precisava contar estória. O cara tirou o dinheiro e me deu. Bom, muito bem, vamos passar para a segunda pessoa.

Comecei de novo. Aí foi, não queria pedir, então colocava o dinheiro na mão e ficava segurando o dinheiro e mostrando. Então passava um e eu esticava a mão. Se a pessoa quisesse dar, parava tirava o dinheiro do bolso e me dava. Foi assim o dia todo. Eu não sei se eu consegui, não sei nem quanto eu cheguei a conseguir naquele dia, mil e quinhentos parece, qualquer coisa assim. Aí eu falei: 'Já consegui um dinheirinho!' Mas estava morrendo de fome e comi. Sobrou um troquinho. Comecei a conversar com as pessoas de lá. Eles falavam: 'Por que você não vende alguma coisa?' Eu falei: 'Puxa é uma boa.'

Mas onde eu vou comprar uma coisa? Um falava: 'Lá na São Bento tem'. Tá bom, tudo bem. Fui para a São Bento, na parte da tarde. Chego lá, começo a conversar com o pessoal, o pessoal já sabe, o pessoal já tem conhecimento. Então falou: Naquele lugar ali'. Atravessei aquela rua movimentada pra caramba, pior que a gente treme, vem carro toda hora. E consegui, comprei a caixa. E aí comecei. Voltei de novo. Eu falei: 'Vou ficar no mesmo lugar que eu estava ficando'. Fiquei vendendo. Mas só que eu notei que vender não era tão bom quanto pedir, não dava tanto dinheiro. Mas tudo bem. Vou vender porque pedir pelo amor de Deus, não vejo graça nenhuma. Mas, sabe quando você está, eu acho que sei lá ... Eu também estava com aquela mentalidade ... não é só porque a gente é deficiente que você tem que pedir as coisas."

As referências ao tempo, no discurso de Márcio, são inespecíficas, a variação do tempo verbal, leva-nos a perguntar a que período Márcio se refere. 
A sucessão temporal não tem a cronologia comum do passado-presente-futuro.

Tal como numa história infantil, a sua história iniciada num reino longínquo, no tempo do Era uma vez, passa a ser contada no presente. Até mesmo os períodos da infância, adolescência e idade adulta não se sucedem como distintos: "Minha vida foi essa durante dois anos e meio, que eu comecei a viver por mim mesmo. Se eu hoje estou vivendo por mim, hoje eu sou ainda, bem dizer, uma criança porque faz 8 ou 9 anos que eu estou vivendo por minha conta."

Fora do círculo do tempo é expectador do seu suceder e muitas vezes, é surpreendido por suas mudanças. A maioria das coisas acontecem "de repente", o tomam de surpresa e o levam, de roldão. Márcio vem para São Paulo para um reencontro, ver coisas que já conhecia e perseguir o movimento, o movimento do "mundaréu" de gente nas ruas, buscar uma luz, um clic, um empurrão que o coloque também em movimento, que o insira no fluxo dos acontecimentos, como agente de mudanças. Mas o primeiro passo para o "fazer" é ignorado, encostar a cadeira num lugar movimentado e pedir. Até mesmo nesta condição de passividade, de espera é difícil soltar a voz, ação mínima necessária para pedir.

Deixar sair a voz requer muito esforço. Mas depois, meio aliviado meio decepcionado, percebe que não é preciso nem mesmo falar, contar uma história. Dar é uma decisão do outro que precisa somente de algum sinal sutil do pedido, a mão estendida basta.

O presente é vivido por Márcio de maneira imediata, o que ganha tem que ser aplicado em satisfação das necessidades básicas: "Mas estava morrendo de fome e comi". Seus planos são construídos para no mínimo ocorrerem no final da tarde do mesmo dia. E a ação, movimento próprio, não resulta tão bem quanto a posição de expectador, "vender não era tão bom quanto pedir". Na realidade, mover-se no meio do movimento alheio é perigoso e assutador, atravessar uma rua movimentada, faz tremer. O movimento mais seguro é que é realizado sem uma finalidade específica, é o movimento circular, andar de metrô pra cima e pra baixo, "ficar rodando daqui pra lá...", "tudo na esperança", na espera, na platéia. 
Só que pedir, também está imiscuido de valores morais negativos, ligados a uma educação, a uma Escola que não guarda nenhuma relação com a realidade da vida lá fora.

Márcio revolta-se com essa Escola, com essa formação que não o preparou para

viver de outra forma e que condena a única saída que encontrou para sobreviver.

"No Lar Escola, apesar que me deu educação, tudo, eu, se começar a analisar o Lar Escola, eu vejo que não me ajudou. Não me ajudou porque eu saí de lá adulto. Eu saindo de lá adulto, eles não deram nenhuma cobertura, tipo, trabalho, qualquer coisa, moradia. Então, tudo isso não foi legal. Se a gente começa a pensar assim não é legal mesmo. Porque de repente, eu vou ter que levar minha vida, tudo vai ter que depender de mim. Mas, puxa, eu não tinha essa mentalidade, eu te juro, não tinha essa mentalidade mesmo. Não é que eu não tinha educação, não era nada disso, pelo contrário. Era porque eu nunca tinha visto esse outro lado da vida. Eu parar no farol e começar a trabalhar, pelo amor de Deus, eu jamais podia fazer uma coisa dessa, jamais mesmo. Mas de repente, eu também via que eu não estava preparado para fazer outro tipo de coisa, como realmente atualmente eu não estou preparado. Se um cara quer me dar um trabalho, nem se for tipo assistente administrativo, eu vou ter que ter algum diploma, ou um colegial ou, sei lá qual que se está pedindo agora. Mas o Lar Escola não deu preparo nenhum. Lá dentro, tudo bem, eu estava trabalhando porque era deles mesmo, e o dono mandou: 'Deixa ele trabalhar. Ele vai trabalhar'. Mas resolveu a parte burocrática, tudo bem. Mas e o resto? Quer dizer, saí de lá sem nada, uma mão na frente e outra atrás. Foi difícil. Então se eu começo a pensar nesse sentido, o Lar Escola não foi legal. Não foi. Foi legal assim de mostrar que existe rico, existe o pobre, que a coisa rica é mais gostosa que a coisa pobre. Quer dizer, esse tipo de coisa, além das pessoas, conheci várias pessoas, tudo isso foi legal. Mas, cadê uma dessas pessoas, até hoje? Eu convivo com elas? Não convivo, você entendeu? Para não dizer não totalmente mesmo, tem uma senhora que mora no Sumaré e que ela foi administradora lá. Essa é a única senhora que eu tenho contato, que até hoje me ajuda, deixa eu passar uns dias na casa dela, ela me dá dinheiro uma vez por mês. É pouquinho, mas é uma maneira que ela consegue para poder me ajudar. Se eu parar para pensar, em uma ajuda real no Lar Escola, não tem. Porque, de repente, no final das contas, eu me vi lá na rua, pedindo ou vendendo coisinhas, coisas que o Lar Escola é contra. Mas se o Lar Escola é contra tudo isso, porque não deu um preparo? Esse papo de internação é muito sério. Hoje eu vejo que é muito sério isso, porque se a gente está lá desde criança ... O que a criança sabe? Criança não sabe de nada, criança só quer brincar. Se o lugar é responsável, eu acho que o lugar tinha que botar um cabresto na gente, falar: 'Você vai fazer isso, você vai se formar, tem faculdade para enfrentar, tem uma série de coisas'. Se eles estão com essa responsabilidade, tinha mais que fazer isso mesmo. Mas, tudo bem. Saí lá do Lar Escola, estou lá no meio da rua, no Centro.

Minha vida foi essa durante dois anos e meio que eu comecei a viver por mim mesmo. Se eu hoje estou vivendo por mim, hoje, eu sou ainda, bem dizer, uma criança, porque faz 8 ou 9 anos que eu estou vivendo por minha conta. Se eu tinha algum problema lá no Lar Escola eles levavam pro médico, eles levavam para os melhores médicos de São Paulo, para os melhores tratamentos. Era uma realidade, na época, superótima. Mas, hoje em dia, eu não tenho os melhores médicos de São Paulo, não tenho. Se eu tenho qualquer doença vou para um pronto-socorro, enfrento aquela fila, 
tenho que ficar ali. Tudo bem. Mas tudo isso numa boa. É a minha realidade hoje. Então, tudo bem. Eu tenho que encarar essa minha realidade.

Eu fui parar nessa casa onde eu moro hoje, através dessa minha madrinha. É a minha madrinha de batismo, legal mesmo. Mas, hoje, se você vem me perguntar cadê ela, eu não sei onde é que ela está. Nesses dois anos e meio que eu fiquei morando num motel, num motel de entra e sai só pra casalsinho, o carinha sempre deixava um quartinho lá para mim, separado, quer dizer, separado não, porque quando eu chegava lá tinha casal no meu quarto, aí tinha que esperar eles saírem, arrumar o quarto para eu chegar lá, tomar meu banho, me preparar para dormir e, no outro dia levantar cedo e ir embora, foi assim durante dois anos e meio. Nesse espaço de dois anos e meio foi os anos mais bacanas da minha vida, porque eu conheci várias pessoas, eu tinha realmente que batalhar pelo meu pão. Isso tudo foi muito legal para mim, gostei de montão mesmo. A amizade ...

Esse, um hotel, era o Hotel Garret. Nesse eu fiquei uns seis ou sete meses morando direto. Foi uma superajuda. Os funcionários desse hotel, de manhã, a gente já conhecia, então uns se interessavam em lavar minha roupa. Minha roupa, minhas coisas, não estava nada comigo, estava tudo espalhado em São Paulo. Deixei um pouco na rodoviária, naqueles malotes que podem ficar lá 24 horas, o cara da banca todo dia colocava uma fichinha pra mim. Foi assim um bom tempo. Deixei um pouco de roupa minha no Hospital São Paulo, com o cara da banca do hospital."

A saída do Lar Escola é vivida por Márcio como abandono, do mesmo modo como a entrada para a atual Casa. A madrinha o deixou lá e não tiveram mais contato.

O período que é recordado como melhor é o que passou na rua, em trânsito. Há um quê de liberdade, e mobilidade, de aventura nestes tempos. A sensação de desamparo latente, própria nessas condições, da sua vida na rua, é compensada pela idéia da expectativa de trânsito, de travessia, de movimento e de mudança.

A possibilidade da continuidade do pensamento fica ameaçada por sentimentos depressivos e este é rapidamente entrecortado pelo "de repente", então, "tudo bem!" Do mesmo modo o fluxo contínuo do tempo e do movimento é interrompido por Márcio por percepções repentinas, pelo modo de contar sua história em "flashes", sem uma linearidade temporal.

"A idéia minha era conseguir uma cota da Caixa Econômica, do governo, tentar formar uma Casa Lotérica.

Mas, nossa! Eu esqueci um monte de coisas. Pulei muitas coisas. Antes disso, de ir para o hotel eu fui até para o Cetrem. Do Cetrem eu fui para outra Casa, outra entidade, lá em Itaquera. Era de um deficiente. 
Deixa eu te contar um dia de trabalho como é. A gente ia para a Vila Formosa, por exemplo, corria o bairro todo. Veja, eu andava sempre com outro rapaz não deficiente. Tem um detalhe: o que eu ganhava tinha que dar um pouquinho para o cara que me acompanhava. Se eu chegava aqui na sua casa, batia palma, aí vinha a moça receber: 'Oi, minha senhora você podia comprar uma balinha para ajudar nossa entidade?' Essa á a coisa que a gente falava. Se a pessoa queria ou não queria, tudo bem. Ou então se comprava dava um dinheirinho a mais, era pra gente, não tinha que dar para a Casa. Então, tudo bem. E outros não queriam nada, mas davam um dinheirinho pra gente. Então era o dia todo de porta em porta, de porta em porta. Tinha rua que era subida, tinha rua que era descida. A minha cadeira, que eu ganhei, acabou nesse trabalho e eles não davam outra cadeira. O máximo que eles faziam era arrumar e pronto. A gente ficava desde oito da manhã até as 5 ou 6 horas da tarde trabalhando. Voltava para casa e aí começava aquele negócio de tomar banho, jantar ... mas tinha só 2 ou 3 pessoas para cuidar de 20. Eu saía nos dias de folga para pesquisar outra coisa. Eu saí de lá com a idéia dessa casa lotérica.

Um dia eu não quis voltar para lá. Para a Cetrem eu não vou de jeito nenhum.

Aparecia gente de tudo quanto é tipo, gente religiosa, gente que não era religiosa, os crentes. Mas alguém que queria me dar algum tipo de ajuda: 'Vem pra cá, tem um cantinho lá, você fica lá, tudo bem, amanhã você sai, vai fazer suas coisas ...', esse tipo de ajuda não aparecia de jeito nenhum. Apareceu a luta do hotel. Tudo Bem. Fiquei nessa vida dois anos e meio."

Márcio fala de sua história como se estivesse fora do tempo. Na realidade, como se estivesse ele mesmo fora da história contada. Como narrador que guarda distância do drama narrado. Um tom róseo e um quê de aventura perpassam seu discurso em dissonância com o que é falado.

Alguns disfarces colaboram nesta tarefa. Vender balas de porta em porta é um deles. Aqui há uma linha muito tênue entre vender e pedir. Só vender, uma frase ambígua insinua e escamoteia um pedido, e ao outro cabe "decidir" se compra, se compra e dá algo a mais, se simplesmente dá ou nega-se totalmente. A ele resta somente subir e descer ruas.

Desta forma há também um desencontro entre o que Márcio espera dos outros e as atitudes destes. Parece não perceber uma explicação para seus atos, o movimento, a ação do outro the é totalmente alheia, incompreensível e imprevista.

Sua primeira expectativa de ajuda não se concretiza. Alguém que ofereça a própria casa, tal qual o herói de guerra inglês, uma verdadeira ajuda, não aparece. Por outro lado, fala de "coisas boas", de gente de destaque, de "madrinhas" e "padrinhos" que lhe deram 
coisas. Do mesmo modo, além das personalidades recebe ajuda de pessoas indistintas, "o metrô virou minha família".

"Mas, tipo assim, tudo de bom acontecia pra mim, sabe, isso é verdade, não posso dizer ao contrário. Conheci pessoas, ganhei cadeira nova e tudo. Conheci gente bem, de destaque, figura tipo Nelson Ned. De repente, foi pra me dar uma força. Foi ele que me deu cadeira de rodas. A minha já estava acabada. Falei com ele, conversei, ele me deu. Uma outra pessoa me deu também uma cadeira motorizada, mas eu não quis ficar com a cadeira por que na hora apareceu uma pessoinha precisando mais do que eu. Era justamente de uma cadeira motorizada que ela estava precisando, então, tudo bem, vamos dar esta cadeira motorizada pra ela, e eu fico com a manual, tudo bem. Eu rodo bem a manual. Então eu comecei a pensar, eu tenho um pouquinho de força, tenho mais que aproveitar. E com uma cadeira motorizada a tendência é diminuir. Então, tudo bem, o metrô virou minha família. A cada estação que eu ia os caras já ficavam esperando: 'Você chegou tarde, pensei que você não vinha, tem um recado lá para vocế não sei onde, vai lá ver'. Já estava bem adiantada a coisa. Tipo: 'Você já almoçou?' 'Já jantou? Não!' Espera aí que eu vou buscar um lanche. Me davam um lanche. E assim a coisa ia indo. Foi durante mais ou menos dois anos e meio. Aí apareceu essa casa, uma comunidade com várias pessoas.

Foi essa madrinha que arrumou. Essa minha madrinha que arranjou. Uma amiga dela sabendo da existência dessa casa. Eu fui lá pra ver. Não estava querendo ver. Falei pra minha madrinha: Não vou ficar lá não. Não quero ficar lá não. Já saí de um lugar, pra que eu vou voltar?' Mas, sabe quando você está querendo ... não está vendo o outro lado da vida, que você quer um cantinho só seu ... E eu começando a pensar: 'Vamos tentar'. E eu fui lá mais uma vez, participei de mais uma reunião deles. Tinha que viajar pra Minas. Ia ficar alguns dias em casa. 'Na volta, quando voltar de Minas dou uma passada aqui, pra ver se eu posso ficar.' Aí quando eu voltei de Minas passei lá, pra ver se eu podia voltar morar lá. Então, tudo bem. Comecei a morar no J..., tive que parar com tudo, metrô, centro da cidade, essa coisa, perdi tudo. Não quis mais. Quer dizer, não é que eu não quis mais, não dava mais, não tinha jeito, deixei quieto. $\mathrm{E}$ agora estou aí. Vender, só vender não foi da noite pro dia, demorei quase dois anos. No J... não achava muito legal pra fazer essas coisas. Depois da ponte não tem lugar, não tem mesmo. Era aquela vida, dormia altas horas da madrugada e acordava lá pro meio dia, aquela vizinha.

Lá tem casa, comida, uma empregada de manhã, e uma no período da noite, tem que ser o mais independente possível. É a norma. Então tudo bem. Partindo disso você faz qualquer coisa. Agora tem tudo lá. Quer dizer, ai com esse trabalho já consegui arrumar outras coisas, conhecer outras pessoas. Claro, muitas coisas ainda estão por vir. Quer dizer, já saí do J... para traballhar na Paulista. Isso eu fiz também, conheci o Chiquinho Scarpa. É outra história legal. Porque eu assistindo aquele programa 'Ricos e Famosos', naquele dia, então era justamente o Chiquinho que ia falar da vida dele. Então eu pensei: 'Tenho que falar com esse cara'. Então, comecei a procurar com quem eu podia falar. Pensei, vou falar com o Ataíde Patrese, vou conseguir o telefone dele. Consegui o telefone dele, conversei com ele, expliquei para ele. Até que, depois de várias tentativas, eu estava cara a cara com o Chiquinho. Fiz uma carta para ele. Aí quero trabalhar. Essa palavra trabalhar, eu queria realmente, mas hoje eu vejo que eu pedi a coisa errada. Eu devia ter pedido um meio de locomoção, para mim. Depois devia ser melhor! Mas tudo bem, nada é errado. A gente tem que passar por várias 
experiências na vida. Então, eu saía do J..., eu pegava uma carona de onde eu morava e ia no balão, saia do balão, pegava essa carona até o ponto de ônibus, pegava o ônibus para ir para a Paulista. Foi assim durante uma semana.

Que a gente viu que não ia dar. Eu trabalhava num Edificio lá dele mesmo, superbacana. Ele é superbacana. As pessoas lá da repartição nunca deixavam eu fazer nada. Eu ia fazer, eles falavam: 'Não, deixa que eu faço'. Praticamente, que motivação?! Aí me chamaram lá em cima, no dia da demissão, é claro. Aí tudo bem, se vocês acham que não dá, tudo bem. Me deram 20 mil na época. Eu não queria pegar o dinheiro. Se não me deixavam fazer nada, porque têm que me pagar? Não têm que me pagar nada! 'Não, por favor, pega' Ficaram com muita insistência até que eu peguei o dinheiro. Aí eu peguei. Tanto foi a vontade que eu estava de fazer as coisas, como realmente eu tenho várias vontades, vários sonhos. De um jeito ou de outro eu bolo um esqueminha e vou fazendo. Então, não é fácil, mas a vida é bem complicada, mas é gostosa, eu gosto, eu adoro. São coisas que a gente tem que batalhar mesmo, a gente tem que brigar, falar alto, ir atrás e tudo isso. Estamos aí."

A entrada de Márcio nesta Casa onde atualmente mora, tal qual todos os processos de institucionalização que Márcio viveu, o coloca em contato com sua deficiência, como fator de confinamento, de estagnação. Quando Márcio fala do Metrô, do Hotel, do Centro da cidade é difícil diferenciar sua história da de qualquer outro migrante sem recursos em São Paulo. Márcio deficiente aparece quando fala das instituições por onde passou.

A vida de Márcio é marcada pela oscilação entre a percepção da estagnação, do confinamento, por um presente sem planos, sem expectativa de futuro, onde os movimentos, as ações são dos outros, restando-lhe o lugar de expectador, vivendo a ilusão que será movido, arrastado pelo fluxo alheio, de carona.

Essa ilusão de trânsito serve-lhe de trem de fuga dos sentimentos de depressão e desesperança que ameaçam seu cotidiano.

Nesta condição não pode nem mesmo perceber os nexos causais dos seus movimentos e dos outros, essa carona, ou qualquer outra "ajuda", ora é vista como um dom de fadas, de protetores, ora um fator insignificante.

Mas mesmo quando consegue fixar um objetivo, arquitetar um plano, uma estratégia ainda que apoiados em outras pessoas de forma idealizada, não sabe claramente o que pedir, como chegar onde deseja ir, e mesmo para onde deseja ir. Seus desejos também são realizados "de carona" quando o itinerário do outro passa por perto. 
Mas Márcio se percebe diferente das outras pessoas da Casa. Uma vez iniciado o movimento, a partir do outro, é capaz de mantê-lo por certo tempo. Não imagina poder desencadeá-lo por conta própria, ou quando imagina, não sabe direito como foi que fez, há algo de sorte, de acaso, mas sabe-se capaz de perseverar, até por inércia.

Quando finalmente, Márcio fala do seu dia a dia na Casa, fala para marcar essa diferença, ele não está acomodado, tem outra atividade fora dali, sai com uma finalidade, é líder, tem opinião, está próximo da diretoria e, por isso, "não pode" entender as razões dos outros. Apesar dessa "distância", partilha a vivência de uma vida isolada, numa Casa não murada, a ambigüidade da solidão, sem privacidade.

"Essa amiga da gente, dá outra carona. Então essa amiga ligava pra ela, pedia pra dar carona e ela dava. Então ela foi vendo esse movimento que eu ia fazendo. Então ela falou 'pode deixar que eu venho todo dia, te busco'. Não, ela falou 'pode deixar que, quando der eu venho te buscar'. E isso virou rotina dela. Até hoje ela vem buscar a gente. As outras pessoas da casa saem também, não com essa finalidade. Só saem pra outras coisas, outros motivos. Não trabalham, eles não mantém atividade, se acomodaram.

É o que eu falei, quando vêem uma mamata, em vez de batalhar, não, preferem ficar acomodadas. O que muda só é o termo que você fala, mas no fundinho é isso mesmo. Eles já estavam lá antes de eu chegar, muitas coisas mudaram e a partir do momento que eu cheguei lá. Por exemplo, eles eram bem parados, nem conversar com as pessoas sabiam. De repente não, eu cheguei, eu vendo tudo aquilo, eu, nossa, que é isso, que horrível. Gente tá na cadeira, mas tem a cabeça, vamos funcionar. Só sabem reclamar das coisas, então, de repente sei lá, foi tipo juntar uma coisa com a outra. aconteceu.

Falei que podiam gritar por qualquer coisa que eles quisessem, foi bem isso que

Falei que com esse tipo de trabalho também, podia entrar dinheiro pra eles. Então, na época, começou a sair quatro de nós para trabalhar, dois iam e ficavam lá no Ibirapuera, e eu e esse moço ficávamos trabalhando aqui perto. Então foi legal, isso estava motivando as outras pessoas. Mas também pararam, porque ficou muito caro chegar até o Ibirapuera.

Ontem, à noite, a gente saiu. Ò noite passamos por aí, a gente foi em Pirituba, na casa de um amigo. Aí nos fizemos este caminho. Mostrei pra minha amiga a sua casa. 'A casa da Rita, ela mora alí'. Daí fui lá, eu também queria comprar almôndega. Saímos a procura de almôndegas. Lá perto não tinha, então aproveitamos pra vir para esse lado para tentar. Mas acabamos comprando lá mesmo, lá perto de casa. Esse amigo, que foi para Pirituba, ele queria comprar também, eu falei: 'Então vamos embora'. A gente nem levou cadeira de rodas, nada. Aproveitamos a carona dele. Lá em casa moram 10 pessoas, dois ou três andam de muletas, é, só dois andam de muletas e o 
resto anda de cadeira de rodas. Lá na frente, no farol, tem um mocinho. Ele mora com a gente, essa senhora que dá carona pra gente me deixa ali naquele lugar e deixa ela lá na praça Pan-americana. O filho dessa senhora estuda no Santa Cruz, então, pra ela é um pulinho alí na praça. Ela é vizinha assim, ela mora muito longe, não perto, mas mora no Jaguaré. Então, pra ela fazer esse tipo de coisa é fora de mão, para ela se torna fora de mão, mas pra ela não, não custa nada. Fala que já tem a saída pra marginal, então, pra ela tanto faz ela ir pra um lado ou pro outro. Ela já arrumou a vida dela conforme a gente, 'Vamos pegar os rapazes lá do outro lado', mas acho que ela faz coisas demais só pela gente. Ela só compra carro que dá pra entrar nossa cadeira. Carro que não entra cadeira ela não compra. Muda de carro todo ano.

O marido dela trabalha na Autolatina, então tem direito de pegar carro uma vez por ano. Então ela só pega carro que dá pra entrar as duas cadeiras, se não, ela não pega. Ela não, ela não pega. Ela faz isso pela gente. Há mais de três anos ela faz isso. Mas esse tipo de coisa começou pela gente mesmo. Assim quando eu comecei a pensar em trabalhar, fazer qualquer coisa.

No começo, o primeiro dia, não foi assim. Fiquei pensando: 'Que eu faço? Onde eu vou agora? Como eu vou agora? Até onde eu quero ir?' Não tinha carro, não tinha nada. Um segurança da gente falou: 'Espera aí a gente arranja.' Passou um amigo, já eram seis horas da manhã, eu estava lá fora, passou um amigo. 'Espera um pouco vou falar com ele'. O cara tinha uma caminhonete velhinha. Dá pra deixar o pessoal em tal lugar?' -'Dá sim, eu vou passar perto'. Eu entrei na frente, a cadeira ficou atrás. Então, neste primeiro dia, escolhi perto da ponte, como tinha muito movimento, 'vou ficar aqui, perto da ponte'. Achei bom ali. Só que foi engano meu, não foi legal. O que ajudou mesmo no primeiro dia é que teve um congestionamento muito grande, tinha havido um acidente e então a rua ficou bem congestionada. $\mathrm{O}$ movimento dos carros foi crescendo, crescendo, então não tinha como os carros andarem, aí eu comecei a oferecer ficha para cada um que estava ali. Aí comecei a ver que dava algum resultado. Na época foi mais de trinta cruzeiros que eu ganhei. No segundo dia eu nem peguei essa carona, chamei um táxi e ele me pegou e deixou no lugar onde eu queria.

Então eu comecei, todo dia ligava pro táxi. Foi essa vizinha de sempre. Até que apareceu uma outra senhora que já conhecia.

Esse tipo de coisa ficou caro. Um deles mexe com eletrônica até hoje, então, preferi ficar lá em casa, ou trabalhar lá mesmo. O pessoal leva aparelho, leva rádio, leva ferro de passar, essas coisinhas mínimas, quebra ele arruma. Eles são aposentados. Eu não sou aposentado. Eu tenho que ir à luta de todo jeito. Eu fui atrás de aposentadoria, mas o pessoal falou que eu não tinha direito de ser aposentado. Eu tenho carteira assinada. Minha carteira profissional é assinada, eu trabalhava no Lar Escola e tudo, então minha carteira era assinada. Na época disseram que eu tinha mesmo que ficar um ano parado. Depois de um ano voltava lá de novo pra ver se eu ia aposentar mas, eu voltei, tinha passado o prazo de um ano, não valia mais nada. Então eu não consegui. Já foi duas vezes que eu corri atrás e o pessoal falou que eu não tinha direito. Quer dizer, direito sim, se eu pagar o INPS durante um ano, mas eu não me preocupei, não me preocupo em ser aposentado, ganhar um dinheiro que não tem nada a ver, não estou batalhando pra aquele dinheiro. Então eu enxergo a coisa assim, tem que ter a obrigação, alguém tem a obrigação.

Ninguém tem a obrigação de nada. Pode até falar que sim, mas eu não acho que eu tenho que receber esse dinheiro que eu não estou fazendo nada. Então eu vou levando. Deixa quieto. 
A gente montou uma capoeira lá dentro de casa, mas a proposta da coisa é bem assim, não pode interferir com a entidade é a proposta. Só que está começando a acarretar problemas. Não são todos que vivem esse tipo de coisa, é uma pessoa só. Então, ... provocou essa discussão. Primeiro, a gente faz a coisa com a diretoria, reunião com as pessoas da casa uma vez por mês, pras pessoas perceberem que o pessoal da diretoria está participando, não está simplesmente dando o que comer, pagando contas e o resto que se vire cada um. Tentando mostrar uma participação maior, pra que o residente sinta isso, faça alguma coisa. Nessa última reunião da diretoria foi colocado esse problema. Daí ficou a solução da gente conversar com o pessoal responsável. Dizer que está acarretando problemas, pra tentar eliminar, ou eliminar a capoeira, ou tirar a capoeira de lá, ou diminuir um dia. Então estava sentindo esse tipo de coisa, ontem a noite. Só que o resto das pessoas não dão sua opinião, ou não querem dar sua opinião, enfim, envolve um monte de coisa. Ninguém fala nada, vai acontecendo ... Pra comunidade, a pessoa faz a capoeira, até paga pra gente de fato o que ela está usando, mas de repente o espaço parece que se torna muito maior do que pelo preço que ela paga.

Então, esse tipo de coisa está começando a acarretar problemas. Foi isso que provocou a discussão de ontem à noite. A pessoa não parece que pode ver um benefício próprio. Se é pra meter o pau em todo mundo, parece que tem apoio de todo mundo, mas se é pra ver uma coisa nesse sentido, as outras pessoas não conseguem se unir, temos uma posição. Nesse caso, então ficou bem assim. Então a gente falou que ia falar hoje ou amanhã com essa pessoa. Tinha outro bingo, mas foi do lado de fora da casa não tinha nada a ver com a gente da casa, mas só pelo motivo do bingo estar ali, quer dizer, então, vem as outras pessoas, vem criança, não para de jeito nenhum, a gente fica alí conversando com aquelas crianças, saem correndo pra lá, aquela loucura. Depois querem água, querem ir ao banheiro, então tudo isso é um problema. Também vão na nossa casa, vão pedir para ir ao banheiro.

Não dá para abrir a tua casa pra todo mundo. Foi falado. Então a gente pega. Eu já conversei com o moço, ele foi lá de manhã. Foi falado, eu falei e ele entendeu. Não, tudo bem, não vai acontecer isso'. É feito lá do lado de fora porque a nossa casa ela é bonita, mas ela tem um defeito, ela não é murada e tem um terrenão grande, não é murada, se alguém está fugindo da polícia ele vai ter que passar pelo nosso terreno, se tem brincadeira, jogo é no nosso terreno. Realmente pro outros moradores de lá, justamente por não ser murado, a gente não tem sossego.

Realmente enche a gente, não sei se enche a gente, se enche eu, mas de repente, eu não ligo, mas eles sim, porque ficam lá 24 horas por dia. É o que eu falo, se realmente vou falar da capoeira, a capoeira não está me atrapalhando, não está, eu entro e saio a hora que eu bem quero, se eles estão ali, eu passo no meio deles acabou, depois se eu tenho que entrar de volta eu entro e pronto, tudo bem, não vejo qual o problema. Que muda algumas coisas muda, que antes, toda a noite, a casa era tranquila, era, era quietinha, hoje não é, por causa da capoeira. Parece que estão querendo cortar até o pouquinho que tem. Realmente eu falei. 'Meu amigo, o pouco contato que você tem ...'

Eu vejo que a pessoa não quer ficar no meio dos outros, quer uma coisa só pra eles. Eu acho que, sei lá se, de repente, sou eu que tenho outras atividades que eles não têm, se quer falar com o diretor procuram eu. Não é só que me procuram, é Márcio que vê isso, é Márcio que vê aquilo. Mas não é que os outros não têm a mesma capacidade, podem até ter, mas se deixar por eles a coisa não corre da maneira mais natural, certas pessoas não conseguem se mostrar para outras pessoas. 
Tanto faz sair como não sair. Essa outra moça que sai para trabalhar, ela é como eu, porque a gente sai, tem outro tipo de amizade, ela não fica constantemente com os outros. Mas antes, e mesmo ela, começou a fazer isso por minha causa. Ela antes ficava lá 24 horas por dia também, sem fazer nada. Ela viu que podia, ia ser bom pra ela, ia ter o dinheiro dela, ter as coisinhas dela, ia ter mais amizades. Hoje vai acontecer uma coisa através do trabalho que a gente fez. É o gerente do restaurante lá perto da praça, convidou a gente pra jantar lá.

Só sei que é o maior barato. De um lado, até como moradia é até excelente, a gente tem um cantinho, isso é legal pra caramba, pode ter suas coisinhas, agora, em termos de convivência que as coisas apertam mesmo. Mas por que alguns têm o que fazer e outros não têm o que fazer coisas mínimas viram problema. Eu até penso: 'Será que estou gostando pra ficar aqui?'

Mas também a gente é obrigado a ficar porque não tem outro lugar.

Então é, sei lá, eu vejo isso de um outro lado, se eu tivesse um meio de locomoção eu já tinha um outro lugar pra ficar. Não sei se realmente a coisa é assim, não sei se é bem assim, mas eu coloco assim, ou é um meio de fuga eu colocar dessa maneira. Mas eu culpo essa falta de locomoção, porque se eu tivesse um meio de locomoção junto com o trabalho, eu já teria batalhando um outro cantinho. Mas como eu não tenho esse meio de locomoção, então não tenho nada. Mas, de fato é isso, se não fosse essa senhora dar carona pra gente como é que eu iria? E pra voltar?

Então hoje a gente vai jantar. Isso é o fruto do que a gente está fazendo. Se ficasse em casa o dia todo nada ia acontecer. Todo o pessoal lá conhece, conhece todos da Praça Pan-americana. Eu já conheço todo o pessoal lá do posto, das fábricas as pessoas que passam por alí. Até agora, não entrou esse assunto da capoeira, agora vamos ver se mais tarde vai entrar ou não vai entrar esse assunto. Parece que quando nada vai incomodar aquele dia, tudo acontece normalmente, mas quando tem uma pespectiva de mudança as anteninhas se ligam. Então vamos ver.

Há muito tempo eles já vinham conversando e eu falando pra esse moço que não ia ser uma coisa legal, que devia ser pensado direito. Nunca dava corda, sempre deixei comentários, eu queria que a coisa continuasse só no comentário, só na vontade dele fazer, só na vontade dele fazer, só que ele colocou para as pessoas da diretoria que gostaria de fazer a capoeira, que ele pagava. Esse rapaz é casado com uma pessoa exresidente de lá, que mora lá nesse lar. Então, tudo isso facilitou pra ele. 'Se uma pessoa, está querendo fazer capoeira aí é uma boa', a diretoria falando isso. Eu ainda mantendo o pé atrás. Não sei se isso vai ser uma boa, mas se vocês querem, tudo bem, a gente pode tentar'. Alguns sabiam que ia colocar capoeira, e outros não sabiam.

Então, de repente, esse pessoal que está levanta esse tipo de coisa, era mais fácil para ela falar que não sobra que a capoeira ia lá, que se ela soubesse iria contra.

Ir de táxi e voltar de táxi ia gastar uma grana violenta.

Uma outra coisa que eu gosto, acho que eu sou um pouco místico, esse tipo de coisa, acho que me ajuda, então eu, muito, adoro parapsicologia. O José P.M. eu li quase todos os livros dele, inclusive o mais terrível que é o poder do subconsciente. Eu gosto muito, quando eu vejo que a coisa não está legal, eu procuro um cantinho meu faço algumas meditações, procuro ver a maneira mais clara de agir. Inclusive, há um tempo atrás, eu fiquei um pouco no curso de parapsicologia. Parece que realmente é uma coisa que funciona. 
De repente eu vejo a maioria das outras pessoas deficientes que tem o seu meio de locomoção é outra cabeça, que eles reagem é outra a maneira. Isso tudo tem porque, porque ele é daquele jeito porque teve condições, mínimas talvez, mas também mínima dentro daquilo que ele pode. Mas uma condição a mais que a minha maneira já é mais do que eu. Quer dizer esse tipo de coisa pra mim seria muito importante, a locomoção. Eu sozinho pego ônibus. Se paro no ponto de ônibus eu tenho que falar: 'Oi, bom dia, tudo bem? Será que você podia me ajudar a subir no ônibus?' Eu não tenho essa cara de pau de pedir. Estou até preparado pra receber um não da pessoa, mas eu sei como é difícil, tudo o que vai fazer ficar na dependência de alguém.

Realmente não é legal. Se eu fosse um milionário tanto faz, eu estou pagando para a pessoa fazer, eu mando e pronto, ai é diferente, mas também aí, nem teria esse tipo de problema. Eu estou usando o que eu tenho: a boca. Se eu percebo que aquele homem é rico pra caramba, jogo uma história pra cima dele, pra ver o que ele vai fazer. Foi o que eu fiz dois ou três dias atrás. Tem um senhor que eu conheci lá no trabalho mesmo. Acho, essa é minha visão, nunca parei pra conversar com ele, eu vejo ele assim como uma pessoa boa, é um senhor alto que inspira confiança.

Eu cheguei nele, deu pra falar uns dois ou três minutos com ele, eu fiz um resumo do total que eu queria falar pra ele. Aí ele mostrando a decisão dele disse: 'Tem o preço do carro?' Já foi meio assim. Eu disse: 'Não, não tenho nada disso'. Essa minha vontade, essa minha necessidade, de uma maneira ou de outra de ter esse meio de locomoção, por outro lado, parece que não faço nada para isso. Devia estar numa autoescola, já estar convivendo com aquele problema de ter um carro, o que devo fazer pra manter aquele carro. Devia estar sonhando mais realisticamente essa coisa, no entanto só está tipo desejo, eu tenho essa necessidade, tudo isso, mas não me realiza no sentido real, mais aí volta tudo de novo porque talvez eu preciso de um meio de locomoção pra chegar num tal lugar pra fazer isso. Mas aí já é frescura minha. Se a semana que vem eu botar na cabeça que eu vou pagar pra ter umas vinte aulas, sei lá, não conheço carro nenhum, então não sei a dimensão, a largura que o carro tem, pra mim sentir tudo isso, pra eu poder começar a dirigir, se eu puder começar a dirigir, se eu ver um buraquinho ali que eu quero estacionar ali, tudo isso eu fico pensando, eu vejo o carro em movimento, será que eu vou conseguir passar por tudo isso? Será que eu não vou apagar numa auto estrada?

Correr, porque tem que correr a 80 por hora, a velocidade é maior do que tudo aquilo que eu imagino. Mas tudo bem. Eu acho que a gente tem mais é que encarar tudo isso.

Eu acho que eu quero, só não sei como eu vou conseguir, mas eu quero."

Há marcadamente um desconhecimento sobre o próprio sentir, suas vontades e desejos, sobre o que realmente incomoda ou é necessário para realizar suas vontades. Contudo, em alguns momentos é possível determinar o que deseja, aproximar o sonho da realidade e buscar "sonhar realisticamente". Para realizar-se ser desejante, o primeiro passo, é saber-se 
desejante, mesmo que o caminho para a concretização do sonho não esteja claro. "Eu acho que eu quero, só não sei como eu vou conseguir, mas eu quero!"

\subsection{SUSPENSÃO DA HISTÓRIA: A RECONSTRUÇÃO DO CORPO A História de Edna}

Edna é uma mulher de 34 anos, portadora de paraplegia por lesão medular incompleta, a nível da sexta vértebra torácica. Mas com certo grau de sensibilidade preservada. A lesão foi ocasionada por acidente de trânsito, há aproximadamente seis anos da época da realização das entrevistas. Mora com a mãe e o irmão em um apartamento de um bairro classe média em São Paulo.

Todas as entrevistas que realizei com Edna transcorreram na sala de seu apartamento, às vezes com a presença e participação de sua mãe. Inúmeras vezes Edna recorreu à sua mãe para precisar datas, confirmar a seqüência dos acontecimentos ou pedir-lhe que complementasse as informação que me prestava. Essas solicitações de sua parte e as intervenções de sua mãe foram se reduzindo com o transcorrer do tempo e o estreitamento de nossa relação.

Do acidente, Edna não fala porque, segundo ela, não se lembra. Ela começa a me contar de sua história a partir desta inconsciência gerada no acidente. Não lembra, por isso não gosta de falar. Não gosta de falar, por isso não lembra. De qualquer modo, indubitavelmente, aquele momento se consistiu em um marco para Edna: apesar de não gostar de falar no assunto, é ela mesma que espontaneamente começa seu discurso por essa ausência do que contar, é ela mesma quem, ao narrar sua história, começa esta mesma história colocando que iniciou-se com um lapso de consciência, com uma descontinuidade da memória.

"Pra falar assim é tão difícil, sobre o acidente eu não lembro direito. Só lembro pelo que falam né, que eu sofri um acidente, o carro capotou, quando eu fiquei dez dias em coma. Só lembro depois que eu acordei. Eu estava dirigindo, disso eu não gosto 
muito de falar, porque eu não sei, não lembro de nada. É dificil você falar de uma coisa que você não lembra, você vai assim pelo que os outros falam, ninguém sabe direito. Eu não estava viajando (eu fui ...), diz que eu estava num aniversário, e eu saí do aniversário e fui pra cidade, eu não gosto de falar porque eu nem sei, eu não lembro quando eu saí, eu não lembro quando eu acordei, essa parte do acidente em si eu não posso falar nada porque eu não sei, eu não lembro com quem eu estava, quem estava comigo, quem deixou de estar, como aconteceu o acidente, quando me levaram para o hospital. Só lembro quando acordei depois de dez dias. Nesse interim não me lembro de nada, só lembro quando acordei do estado de coma, mas depois que eu acordei, eu fiquei mais, porque eu fiquei em Jundiaí, eu nem me lembro direito, eu fiquei no Hospital Paulo Sacramento, eu não lembro direito porque foi tão tumultuado, eu estava tão em choque. Depois que eu saí da UTI aí eu fiquei mais ou menos uns 15 dias, depois eu vim para São Paulo para o Hospital Santa Isabel. Aí do Santa Isabel eu já lembro tudo."

Seguiu-se a esse "acordar", a essa retomada da memória não uma clareza súbita

e total dos acontecimentos e de si mesma. Ao relatar esses momentos, Edna titubeia na seqüência e detalhamento do ocorrido. Seguiu-se, sim, um período de estranheza do próprio corpo, uma ausência de sensibilidade e de propriocepção. Há a percepção de um mundo e de pessoas alheias às suas experiências anteriores, que se movem estranhamente.

"O I. S. I. é dentro do Hospital da S. C. Eu fiquei lá uns três meses. Desses três meses eu lembro de tudo. Ficava lá no quarto, fazia fisioterapia todos os dias, fui operada, fiz duas operações, uma de clavícula, do braço, foi preciso enxertar e amarrar todos os ossos, porque praticamente moeu tudo, tiveram que fazer enxerto e por platina no braço. A primeira operação foi nas costas, porque eu quebrei uma vértebra, a sexta vértebra torácica. Devido a eu ter quebrado a vértebra, comprimiu a medula, porque eu fiquei muito tempo para ser operada, não houve uma emergência, me deixaram lá no hospital, todos esses negócios, então comprimiu, conforme a compressão, lesou a parte motora, aí eu fui ... mas nesse interim eu fiquei paralisada durante um ano, faz um ano que eu fiquei paralisada. Minha mãe me dava comida na boca, eu bebia água de canudinho, perdi todos os movimentos, só tinha o movimento só do pescoço. Não ficava deitada, com quatro dias da operação eu já sentei, neste ponto eu tive uma sorte tremenda, graças a Deus. O médico também falou, disse que era bom eu ficar sentada, elevar o bumbum, para não ter problemas de escaras, porque, olha até hoje são cinco anos eu nunca tive uma escara, nunca tive uma infecção, nunca tive nada, graças a Deus, nada, entendeu? O tempo que eu fiquei no hospital, as minhas costas ficou toda ferida porque caiu todos os vidros nas minhas costas. Aí eles tinham que colocar uma espuma, tinha que ter muito cuidado, colocavam espuma nas costas, nos pés para não deformar, os pés entendeu? Fizeram isso daí. Eu tinha fisioterapeuta no quarto todos os dias, além da fisioterapia que eu fazia lá na Santa Casa. Eu saía do Santa Isabel ia para Santa Casa, também todos os dias. Era de manhã a fisioterapeuta ia no quarto, e à tarde era lá na Santa Casa. Com quatro dias eu já sentei. Lá eu fazia das pernas, eu me lembro, antes de operar dos braços eu fazia fisioterapia das pernas, todos os movimentos que eu não fazia das pernas, a fisioterapeuta fazia, aí depois que eu fiz a operação, depois de oito dias que eu fiz a operação de coluna, eu fiz do braço, aí 
depois, nossa uma dor terrível, meu Deus do céu, o braço era uma dor terrível. Uma coisa incrivel, porque eu queria fazer os movimentos, são coisas que é ... é uma coisa fantástica. Você queria fazer os movimentos, mexer, eu queria mexer com o corpo, me virar e não conseguia, agora hoje já consegui $80 \%$ dos movimentos, então já é uma coisa, mas você fica pensando, puxa vida sabe! tem que ter uma pessoa que me mexesse sabe, me virar, um monte de coisinha né? Nossa! Uma coisa assim fantástica, no caso quando eu estava na fisioterapia aí eles colocavam uma goteira em mim, para conseguir levantar. Não! primeiro eu fiquei numa barra, que era elevada, ai elevando meu corpo, porque eu fiquei muito tempo paralisada (não, mais até aí eu já, eu ... ainda estava ...), eles tinham que elevar o corpo, todos as vezes que elevava o corpo eu sentia tonturas, por causa que eu fiquei muito tempo deitada. Menina, quando eu consegui chegar no 90, 360 graus, nossa! eu vi tudo ali na Santa Casa, ali, coisa assim fantástica, porque eu já tava assim em pé, porque eu ficava em pé mesmo, mesmo na prancha, mas eu ficava em pé. Foi uma coisa assim fantástica. Aí, depois eu via as pessoas de andador, aparelho, de prótese, eu falava assim: 'Será que eu vou chegar?' Sabe, porque é um processo devagar, lento, mas você vai adquirindo. Aí foi onde eu fui adquirindo os movimentos dos braços, do corpo. Eu fui fazendo fisioterapia, de mexer, foi onde eu fui conseguindo."

Tudo the parece "fantástico" porque sente o mundo irreal e estranho. Seu próprio corpo tornou-se objeto exterior e distanciado de si mesma.

Seu corpo não the parece mais familiar, é estranha a ausência da resposta automática e espontânea dos músculos ao comando da vontade.

Houve esmagamentos e compressões que romperam essa ligação imediata com o corpo e, conseqüentemente as vinculações com o mundo, mediatizadas justamente por este corpo.

"É um processo lento mas, de repente, quando eu pegava o peso e me virava e conseguia me virar, era uma coisa assim fantástica, era como se eu tivesse descoberto o Brasil. Nossa! Quando eu elevava o tórax, também, todos esses processos de fisioterapia, quando eu fiquei a primeira vez em pé de goteira, eu falei: 'Não, não é possível!' Porque você, eu, no começo até ali, é como se eu tivesse, olha como é a coisa, eu tava em pé, mas não sentia que eu estava em pé, eu não sentia, era como se eu estivesse numa superficie, assim, elevada, uma coisa estranha. Olha como é que é, hoje eu já fico no aparelho para lá e para cá, faço os movimentos tudo em órtese, é lógico, mas eu sinto, eu sinto os movimentos tudo. Mas naquela época eu não sentia, era como se eu tivesse só com o pescoço. Agora que a gente vai lembrando então, era uma coisa estranha, eu não me sentia em pé, eu estava em pé, mas não me sentia em pé. Aí foi onde, quando eu senti o meu pé no chão, eles trabalharam muito comigo, na parte de fisioterapia, de massagens tudo, para voltar a sensibilidade, porque como eu tive uma compressão muito minima, eles estavam batalhando pra eu voltar a sensibilidade, aí quando eu consegui, a primeira vez que eu coloquei o pé no chão, que eu senti o pé no chão, eu falei ninguém me segurava, menina, eu andava tanto, que tinha que ficar uma hora, eu ficava quatro horas para lá e para cá, parecia ser tonta. Incrivel né?" 
Edna vai nos falar, o tempo todo, da destruição dessas ligações, que se instalou a partir do acidente, que foi de uma certa forma, uma ruptura na sua história, e do seu trabalho lento de reconstrução.

Por que caminhos está efetivando esta reconstrução, em que direção e se trata mesmo de uma reconstrução ou de uma remontagem? São questões que pontuam a interpretação de seu discurso.

Pode-se identificar quatro tempos nesta história de reconquista de Edna pelo próprio corpo: o período hospitalar, logo após o acidente; o tempo dos trabalhos e progresso com os movimentos, em casa; o momento da busca da independência pela reabilitação; e, por fim, as experiências e expectativas que vive hoje pelo avanço da ciência e da sofisticação tecnológica.

No tempo do hospital, Edna fala primeiramente das conseqüências corporais do acidente, do esmagamento do braço, da compressão da medula, das dores, das feridas em suas costas, da sua imobilidade e fragilidade. Após intervenções fisioterápicas que ainda não compreende direito, os primeiros movimentos vão ocorrendo para sua perplexidade.

Há um descompasso, um grande desencontro entre suas experiências sensoriais, motoras e o que consegue apreender intelectivamente. Essas ligações estão suspensas. Sabe-se em pé, mas não se sente com os pés no chão. Não se lembra como perdeu a possibilidade de ficar em pé voluntariamente nem mesmo compreende como refaz essa postura naquele momento. O que é ação sua, trabalho do fisioterapeuta ou apoio da prancha ortostática?

Este processo de reaparecimento dos movimentos vai prosseguindo com o passar do tempo, mesmo depois da saída do Hospital. Aliás, o Hospital continuará sendo um espaço de referência para Edna quando volta para casa, ou quando quer buscar outras alternativas de tratamento. 
"Aí foi passando, passando, fui adquirindo os movimentos. Isso tudo dentro do hospital, não, até aí não, aí eu estava em casa. Porque depois, eu fiquei três meses, depois que eu saí do hospital. Não! Depois que eu saí do hospital, eu ainda fiquei lá, fiquei indo lá acho que um ano, na Santa Casa. Aí, depois eu vi que eu não tinha mais campo lá dentro, era tudo aquilo, a mesma coisa, a mesma coisa. Eu sou uma pessoa que anseia, sabe, eu tenho aquilo alí, então vou, mais vou mais, vou mais. Eu acho que foi isso que me fez conseguir o máximo. Não, porque têm pessoas que são acomodadas, ficam alí, eu não, eu vi que alí não tinha mais campo para mim. Eu tinha uma espacidade*, assim, nossa! tremenda! Uma coisa assim de a minha perna jogar minha mão longe, sabe! Na cadeira higiênica, as minhas pernas entravam naqueles buraquinhos alí, entravam alí, de espacidade tão forte. E aí também, eu digo que é sorte, porque tudo caiu direitinho na hora, que eu mais ...

Nesse interim do acidente até agora tudo que eu tinha intenção de alguma coisa, parece que caiu em cima de mim, incrível! Aí minha irmã tinha um amigo que era fisioterapeuta da Casa de Recuperação do Morumbi. Mas antes desse, tinha a C.

Quando eu saí da Santa Casa, eu não conseguia andar direto, só andava só no pararelo, e o meu fisiatra falou, pediu para me expandir, pra eu tentar sair, sozinha, andar sozinha porque eu não andava sozinha, andava só nas paralelas. Aí eu fui em Campinas num outro fisiatra, porque eu era assim, tava em um, não ficava satisfeita com aquele, ia para outro, sempre procurando melhoras, melhoras e melhoras e melhoras, porque se você parar, fica no tempo e adeus. Aí eu fui lá e aí ela falou assim é verdade, você precisa, me deu o endereço, não, entrou em contato com essa fisioterapeuta. Ai deu todos, todos os programas, porque eu não poderia ir para Campinas, então como ela morava aqui era mais fácil me atender em casa, que é onde ela fazia a fisioterapia dos movimentos, e ela me ajudava a andar sozinha com aparelhos, sempre ali, em volta, mas era sozinha, por causa da espacidade, a espacidade era terrível. Nossa quando eu elevava o corpo, até eu me acalmar, nossa minha filha, era quase uma hora, já quase terminando a fisioterapia. Mas eu consegui andar. Mas era assim muito lento. Aí eu vi também que aquela fisioterapia já estava ultrapassada e tinha que tirar. Essa fisioterapeuta lá da S. C., muito boa, não desfazendo da capacidade dessa que me atendia, mas ela falava pra mim, porque eles queriam tirar minha espacidade, com uma operação, e eu fiquei sabendo que essa ..., se eu fizesse essa operação, ela me

* Trata-se de espasticidade. 
inutilizava, aí eu perdia ... eu tinha poucos movimentos, mas eu perdia todos os movimentos que era o nervo. Ai ela falou não faça Edna, procure uma pessoa que possa tirar através da fisioterapia, que pode tirar."

O tempo da volta para casa irá marcar o momento de aplicação dos movimentos recém-conquistados em um espaço familiar. É preciso controlar os espasmos, esse corpo desgovernado e fazê-lo mover-se para além das barras paralelas.

Edna parece apropriar-se um pouco mais desse processo. Ela é "uma pessoa que anseia", deseja sentir-se em ação, para isso busca as mudanças de terapeutas. Já pode perceber que "não há mais campo" e decide mudar-se, embora ainda não fique claro exatamente pelo que anseia.

Os limites que a fazem mudar de um terapeuta para outro são percebidos nos espaços exteriores, nos outros, nos serviços, não havendo menção a possíveis limitações intrínsecas à sua condição. De outro lado, essa busca por melhoras tem um quê de mágica coincidência, onde um movimento seu, próprio, de procura, é secundário à sincronicidade do mundo que the traz as respostas à sua porta.

Podendo mover-se mais, até de um serviço a outro, Edna pode restabelecer a capacidade de vincular-se. Nesse momento, pode mover-se em direção a um fisioterapeuta e ligar-se afetivamente a ele. Qual um "pêndulo", ele the dá a segurança necessária até para oscilar, dentro de certos parâmetros. É preciso para andar, ficar em pé sozinha, mas, mover-se alternando os pontos de equilíbrio.

"Por coincidência, a irmã tem um amigo que é fisioterapeuta, que por sinal muito bom, porque olha, eu gosto muito do meu fisiatra, falo pra ele assim que é Deus no céu e ele na terra, mas esse fisioterapeuta também, nossa, ele era fisioterapeuta, analista, amigo, tudo. Nossa, foi um cara assim fantástico, foi uma pessoa que passou pra mim a vida né, que foi muito bom, nossa, ele me ajudou muito. Porque eu ainda estava com a cabeça a 300 por hora. Aí ele fazia fisioterapia comigo, eu era muito manhosa, entendeu? eu ainda tava muito manhosa, ainda tava no comecinho, tudo era dorzinha, e ele era muito enérgico. Então ele caiu assim na minha vida no momento exato, porque eu precisava de um puxão de orelha, sabe? E de todos os incentivos, tanto de fisioterapia, como psicologicamente, aí foi ótimo, ai ele conseguiu tirar toda essa espacidade minha. Aí quando ele... Um fisioterapeuta muito bom, aí ele conseguiu através da amizade abrir uma clínica no Belém do Pará, Paraíba. Um negócio, assim, 
não lembro assim. Aí ele foi embora, mas ele conseguiu ... Foi embora mas conseguiu me deixar em pé, andando assim numa boa, ai, depois dali, ninguém me segurou, ai eu melhorei também de cabeça."

Essa relação viabilizou transformações importantes para Edna, significando principalmente um contato mais íntimo com a vida. Contudo, estava projetada na figura do outro e quando este vai embora, Edna entra em um profundo processo depressivo. Parece ser o primeiro momento em que Edna, sentindo o pé no chão, pode entristecer-se com as perdas sofridas. É o primeiro momento em que se questiona para onde vai, o que vai fazer.

"Aí, daí eu fui pra onde? Ah! eu tava ... quando ele foi embora, nossa, ele me deixou arrasada. Acabou, parece que acabou a Edna, porque é como se tivesse tirado um pedacinho de mim, por incrivel que pareça. Não tinha nada, ele era meu fisioterapeuta, tinha uma amizade fantástica com ele, não existia nada assim de sentimentalismo nem nada, existia era uma amizade muito boa, mas eu me apeguei tanto, era como se ele fosse um pêndulo, aí eu fiquei. Eu falei: 'Que eu vou fazer? Eu não vou fazer nada, vou morrer, porque não sei o quê'. Nossa, foi incrível, porque fiquei com uma cabeça terrível."

De qualquer modo, essa relação deixou marcas que não se perderam. Na própria fala de Edna, mais estruturada, até vão aparecer menções a relações de amizade e preferências, gostos pessoais, anteriores, apontando a sua religação com os outros e com seu passado.

"Aí um ajudante lá de fisioterapia da S. C., que eu tive muito contato, peguei uma amizade tão grande com o pessoal de lá. Porque é assim, eu ficava no quarto, era eu e minha mãe. Minha mãe praticamente morou comigo lá no hospital. Então vinha enfermeira, vinha os médicos, ficava assistindo televisão, conversando, eu fiquei ... Olha, por incrivel que pareça, nesses três meses que eu fiquei lá, pareceu que eu não tava no hospital, eu não fiquei no hospital. Porque o hospital é uma coisa ruim, chata, mas eu não fiquei no hospital, lá parecia que eu estava num hotel. Sabe! ficava todo mundo, vinha me visitar, a noite ficava todo mundo alí rodeando, conversando tudo. Eu adquiri uma amizade assim fantástica lá dentro, incrível, uma coisa assim fantástica. Aí o pessoal sempre vinha me visitar, depois que eu saí do hospital me telefonavam tudo, era do médico até a pessoa que me ajudava a tomar banho, aí menina! É como eu falei para você, parece que cada vez que eu precisava de uma pessoa, caia assim em cima. Aí o menino que me ajudava a colocar o aparelho, a me elevar o corpo, tudo. Aí ele vinha me visitar porque eu tinha, antes do acidente, eu tinha um canil, eu sempre gostei de animais. Sempre gostei, não! Gosto! Se me deixarem assim no zoológico, eu fico assim grata, então aí eu tinha assim um monte de cachorro, gato, aí eu dei o gato siamês pra ele, pra saber como é que tava a Bianca que era minha fillinha, saber como é que tava tudo. 
É, mais uma vez no retorno ao hospital, nesse momento não mais um lugar alheio e estranho, mas um espaço onde floresceram amizades, que Edna vai buscar uma saída. Na realidade, esta saída não se consistiu em uma alternativa efetivamente diferente daquelas que vinha experimentando até então. Edna irá em busca de outro médico e este lhe falará de reabilitação.

"Aí eu falei pra ele. Ele falou: 'Olha Edna, tem um fisiatra muito bom, ele é Doutor S... que é o fisiatra da S. C., e o Doutor C... que é o fisiatra das Clínicas. Não custa nada você ir lá'. Aí eu fui lá no Doutor C.... porque o Doutor S... é da S. C., é o meu médico que continua sendo até hoje. Então eu falei 'tá bom', marquei uma consulta com ele. Fui lá, ele me examinou tudo, e falou: 'Sua operação foi muito bem feita, essa compressão comprimiu muito, você tem que passar por uma casa de reabilitação para vocề adquirir uma independência'. Porque eu não tinha, até para eu sair tudo. Aí eu falei: 'Tudo bem'. Aí ele me mandou para Vergueiro. Aí eu falei: 'Tudo bem'."

É a primeira vez que Edna se defronta com o aqui e agora da situação que está vivendo. Com o passar do tempo e "a corda no pescoço", ou seja, premida pela realidade do momento, precisa "reaprender" a fazer coisas sozinha, de uma forma independente. Toma contato também com outras pessoas deficientes que não estão na condição de pacientes, como era no Hospital. Entretanto, esta experiência é reinterpretada por Edna como algo que deve aprender para poder se virar melhor, de um modo menos dependente, enquanto espera. A reabilitação tem um quê de escola: "Da DEPV se sai apta, com um atestado de capacidade, para fazer 'tudo'". Esse tudo parece se restringir às atividades domésticas.

Dentro de casa, ela consegue fazer tudo, tudo está arrumado e em ordem.

"Aí eu fui lá para a Vergueiro. Passei por uma triagem, tudo, foi lá que eu ... Por isso que eu falo, falo que se na Vergueiro você não sair boa, você não saí em lugar nenhum. Porque eu acho que não teve clínica aqui em São Paulo que eu não tenha passado.

Na Vergueiro você sai assim apta a fazer tudo, olha tudo arrumadinho, eu faço tudo, graças a Deus, não tem nada, faço tudo, tudo, tudo, a única coisa que eu não me 
atrevo a fazer muito é passar roupa, eu tenho receio do ferro cair em cima de mim, é psicológico eu acho, porque se eu tentar ... Foi lá que eu adquiri tudo ... bom eu já tinha chegado com certa bagagem, aí eu fui no caso soltando aquilo que eu tinha, porque você vai passando o tempo, você ... minha filha, se a corda está aqui, você tem que soltar, alguma coisa você vai ter que fazer, sozinha. Comigo a minha mãe, minha mãe já é de idade, não pode tanta coisa fazer. Eu também não tenho muita paciência de ficar: 'Mãe pega isso, mãe pega aquilo'. Meu espírito já é mais agitado, tem que tá assim sempre a 300 por hora. Foi lá minha filha que eu adquiri toda a minha reabilitação tá, tinha um monte de coisa, ajudava num monte de coisa, porque eu sabia, assim, eu sou daquelas: vamos lá na frente, vamos lá lutar, ai foi muito bom, foi lá também que eu participei, participava de reunião. Eu fiquei sócia lá da secretaria dos deficientes, porque eu não tinha nenhum contato, tava meio fechada alí. Aí foi lá, na Reabilitação Vergueiro, que falou assim: 'Você precisa se expandir', porque eu tava muito ligada às minhas amizades antigas. Então eu não saía dali. Aí foi onde, que eu procurando, vendo, vendo, vendo, mas eu não saía também, nem daqui até alí, na porta, aí foi onde eu fui me soltando, me soltando."

Porém, essa "reabilitação" não the tirou de casa, nem the devolveu o estado anterior das coisas. O "máximo" ainda está muito aquém do que deseja. E mais uma vez Edna se volta para o Hospital. Seu médico the fala de equipamentos, vindos do Exterior, que podem lhe devolver o andar, não mais com pesadas órteses, mas simples eletrodos.

O seu processo de reconstrução, iniciado com o recobrar da consciência, prosseguido pelo enxerto de ossos, a retomada dos movimentos e da sensibilidade, e a expansão desses movimentos no espaço da casa, ganha novamente um ar "fantástico" pelo progresso da ciência e a utilização da alta-tecnologia. Neste momento, o corpo robotizado distancia-se novamente. A conquista e o desafio é dos cientistas.

"Aí eu saí da Vergueiro - não na Vergueiro foi passando o tempo, a medicina vai, tendo mais coisas, aí saiu um aparelho de F.E.S., da Iugoslávia, aí eu falei, bom, já na Vergueiro não dá mais, porque eu cheguei no máximo, no máximo mesmo, aí eu voltei pro meu antigo médico da S. C., que ele é o foco de fisiatra, de tudo quanto é coisa. Aí voltei para ele, Dr. Sérgio, aí marquei uma consulta, com ele. Mas, mesmo assim, nesse interim que eu passei por outras clínicas, eu sempre estava em contato com ele, tava me acompanhando né. Daí ele falou: 'Tudo bem Edna, vamos fazer um teste, porque não é todo mundo que se adapta a isso daí'. Fui fazer o teste, me adaptei, tudo, ele falou: 'Vai ser muito bom para você. Primeiro por causa de tua musculatura, por causa da espacidade, porque se você fica um pouquinho parada'. Já eu tenho problema de espacidade, então aí foi onde que eu fui fazer o aparelho. Fui lá fazer teste tudo, aí eu continuei o tratamento lá. Eu voltei para lá, só que não era na S. C., era na clínica dele particular, lá na Luiz Góes. Aí eu fui lá, ia três vezes por semana, segunda, quarta e sexta. Ai foi onde eu adquiri uma coisa fantástica também, andei, sem nada, aí foi outra coisa assim fantástica. Só com eletrodos, era só colocar um aqui, porque o foco de 
minha parte é o joelho. O controle motor afetou o joelho, então coloca um aqui outro aqui, ai liga. Porque o nacional, ...(tem o nacional) só que é muito leve, por causa da minha espacidade. Então o choque tem que ser mais elevado, e o F.E.S. nacional ele não consegue deixar muito tempo em pé. Aí eu tiz, tinha que mandar pagar, não era barato naquela época. Aí eu falei: 'Bom, como eu ajudei tantas pessoas, fazendo listas, tudo, para todo mundo, agora vou ser eu, foi onde que eu fiz, Aí recebi ajuda também, como eu falei para você, chega tudo em cima para mim. Graças a Deus. encontrei um monte de gente que me ajudaram a passar lista, consegui aparelhos para fazer rifas, um monte de coisa. E a firma que eu trabalhava, era de exportação também, aí movimentei também a firma, eles conseguiram entrar em contato com a Iugoslávia. Eu tive a sorte, que uma semana que chegou esse aparelho entrou a guerra. O pessoal falou: 'Puxa, Edna!' Eu falei graças a Deus, então eu consegui que o pessoal lá de Miami, que era a matriz da afirma que eu trabalhava, entrou em contato com a Iugoslávia e eles conseguiram um intercâmbio, só sei que eu consegui, recebi o aparelho. Aí eu fiz teste, tudo, aí também já comecei andar, tudo, mas não era aquele andar, não é aquele andar forte, não expandi muito, você quer o máximo. Agora eles estão conseguindo ... tentando conseguir um que, lá na Iugoslávia, como é a guerra, não tem condições, de pegar, então eles estão conseguindo aqui no Brasil ... Inclusive foram vários testes tudo. E eu fui uma cobaia, né, para eles conseguirem um de quatro canais, porque o meu tem dois. Ele faz o seguinte, ele faz os movimentos e anda um pouco, o outro de quatro canais, eu já fiz teste, só que eles não conseguiram adaptar porque tem um monte de fios, e quando você vai andar, pode até cair, porque é um monte de fios tudo, porque dois canais é um aqui outro aqui, o outro seria um embaixo, e um outro aqui onde seguraria o quadril, onde teria os movimentos do quadril, ele elevaria e você faz os movimentos normal, é uma coisa assim fantástica, eu já fiz a experiência. Nossa, quando eu consegui, eu falei, como é possivel, meu Deus do céu, agora eles estão conseguindo."

Ainda assim, esse andar não é o andar "máximo", da ordem do seu desejo, por isso interessa-se pela cirurgia que talvez the transplante de volta para antes do acidente. Enquanto espera, é preciso ritualizar o cotidiano e trabalhar o corpo para que se preserve o que já reconquistou. A condição de "imobilidade" e a posição sentada the são incômodas, fazem doer. É preciso exercitar-se cotidianamente e manter o corpo disciplinado.

Por vezes, Edna lamenta essa condição limitadora "parcial", dado que, talvez, o corte, a secção total da medula, a impossibilidade total, definissem uma situação menos dolorosa.

"Aí, como já estava ... já tinha conseguido o máximo neste aparelho também, aí o S... disse assim: 'Agora, né? vamos esperar o outro, só que você ... eu te dou alta, você fica em casa. Só que faz esse negócio'. Ah! aí quando eu tava fazendo esse aparelho, teve o mês de julho, veio um cientista francês aqui para o Brasil. E eles falaram de uma operação que eles estão fazendo nos Estados Unidos. Aí o S... falou: 'Vamos trabalhar em cima de você, quando chegar nós já estamos prontos'. Aí, ele foi trabalhando em cima de massagens para não atrofiar nada, porque se atrofia já vai ter 
problemas, então foi onde eu já estava começando a fazer massagem, o aparelho e a órtese também. Porque a órtese eu faço ela todos dias, porque eu tenho que andar, porque eu não agüento, porque eu tenho a sensibilidade, tenho sensibilidade no corpo inteiro - foi só a parte motora, quer dizer, num ponto é bom e num outro ponto é uma cacetada ... porque eu sinto dores no corpo todo ... porque se eu fico muito na cadeira começa a doer a batata da perna, começa a doer o quadril, começa doer o ossinho, começa a doer as costas. Aí começa, aí eu tenho que andar, duas ou três voltas, fazer o movimento para esticar todo o corpo. Se não eu não agüento, e tem que fazer o aparelhinho para não dar problemas de atrofiação e nem voltar, a espacidade, porque essa, se voltar meu Deus do céu, e tem que fazer a massagem por causa da musculatura também porque ela está parada, então a musculatura ... tudo, não cedeu nada, graças a Deus não cedeu um milímetro, em cinco anos, eu passo todo mês, o médico ele mede, para ver se tem alguma coisinha. Nada. Mas também eu trabalho. Òs vezes eu tenho vontade de não fazer nada, não vou fazer nada hoje, mas aí já vem aquele negócio na minha cabeça, e se você não fizer ... aí sou obrigada a fazer."

Enquanto as experiências são realizadas, só the resta esperar. Neste caminho a sua atuação é muito limitada. a ação cabe ao outro, a ela só a expectativa da cura.

"Então aí foi isso daí. Aí fui fazendo isso daí, aí voltei para casa, aí eles estão em teste com quatro canais, que vai um passo assim na recuperação, porque esses dias ele me telefonou e falou ... Disse que uma pessoa ... que fez essa operação tinha uma musculatura boa, uma criança, porque tem vários ...tanto a paraplégica, o tetra tudo tem vários tipos né ... e esse menino que fez, ele tinha a medula dele, era toda molinha, daquelas pessoas que não tem o pêndulo, a firmeza, porque no caso, você, você tem firmeza. Ela era toda molinha que nem uma bonequinha de pano, aí eles foram fazer um teste, porque eles estão fazendo o teste na parte mais difícil, aí eles foram fazer um teste, o menino não agüentou, aí o plano foi pra cucuia.

Mas infelizmente ... ele falou se, se uma parte foi pra cucuia, mas eu, outra, a gente vai. Infelizmente a morte de um, vai ser o sucesso de muitos outros, porque nós vamos fazer experiências. $O$ que aconteceu? $O$ que foi que rejeitou? Então estou esperando esses quatro canais, tô fazendo aqui em casa, e tô esperando todo dia que a operação dê certo."

Essa espera congela a sua reinserção no fluxo do tempo. Edna, algumas vezes, tem dificuldades na utilização do tempo presente ou passado: "Gostei não, gosto", "chamava não, ainda está vivo". Não está claro o que pertence ao agora, o que vem do passado e continua hoje, o que já findou. E o futuro? Parece não haver menção ao futuro, exceto expectativas da ação alheia. Só há o tempo da recuperação das coisas do passado que, pela paralisia ou desuso, perdeu. Na verdade, Edna não parece conceber perdas definitivas. Espera reconquistar-se pelo 
trabalho cotidiano, por não se acomodar ao "status quo", por ansiar o máximo. Não se trata de desejar o novo, o futuro, o que ainda não viveu, mas recuperar os movimentos, a rotina anterior.

Trabalha o próprio corpo tal como um músico exercita-se no seu instrumento, ensaiando a partitura que tocará em breve.

Enquanto espera, ensaia um discurso autoconsolador. A espera gera um tempo de sobra com o qual pode observar a vida, as pessoas, os gostos das coisas. Dá-lhe uma perspectiva de sobrevôo. Ò margem do ritmo dos acontecimentos reflete e pesa as perdas e ganhos.

"Moro, eu e minha mãe, e meu irmão, antes do acidente também, graças a Deus, minha mãe foi meu anjo da guarda. Oh! meu Deus! pela fase que eu passei, porque é assim! Quando acontece alguma coisa com você, você tem um monte de gente ao seu redor, mas ah! ah! minha filha! pra cuidar de você!!! nem namorado, nem marido, nem ninguém, apesar de ter pessoas que têm sorte, eu vi muitas pessoas que estavam casadas e deu sorte, e tem outra que não deu.

Eu fui casada, já estava mais ou menos separada quando sofri o acidente. Aí quando eu sofri o acidente e que. ele foi embora de vez. Então, mas tinha a minha amada mãe, que foi alí, né comigo. Graças a Deus. não tenho... não tenho nenhuma coisa, lógico que você vai adquirindo. No começo o mundo caiu em cima de você. Eu tinha, no começo ... no caso, quando eu voltei do hospital eu falei: 'Vou destruir tudo, destruir tudo!' Você acredita: roupas, sapatos, essas coisas de parte pessoal, acho que tudo, tudo, tudo, parecia que a Edna morreu, destrui tudo. Acabou a Edna, aí aos poucos eu fui levantando, fui adquirindo um monte de experiências, com tanto que as pessoas falavam assim, puxa mas, coisas assim, acidente, desastre, digo desastre, na maneira global, para não falar ..., mas você sabe que você adquire um monte de experiência, um monte de coisas boas, pelo menos pra mim, por incrivel que pareça, esse acidente, não houve coisas assim tão ... houve, lógico, Oh! arrebentou um monte de estruturas tudo, mas eu ... pra mim não houve tantas conseqüências muito graves, eu tive nossa Ele fechou uma porta, mas Ele abriu um portão assim enorme para mim. Sabe! porque depois disso, pelo menos eu posso falar, os meus amigos são meus amigos, eu posso falar de boca aberta, sabe! De boca cheia também, são meus amigos, eu tenho amizades. Antes eu não tinha, sabe! Você vê um monte de coisas assim, você adquirir mais experiência, porque você tá ... Quando eu tava boa ... eu digo antes do acidente, eu não tinha muito tempo pra parar, pra pensar, para ver o vizinho, para ver isso, pra ver aquilo. Hoje eu já tenho tempo. As coisas pra mim é mais substancial, mais assim saborosa, eu saboreio com mais prazer, cada coisa que eu faço eu saboreio melhor, porque eu tenho mais tempo, talvez seja isto. A experiência também que faz você enxergar as coisas, os amigos, família, também pessoas que não tinham contato nenhum com a minha família, primos que nunca conheci e acho que nem tinha visto, 
problemas, então foi onde eu já estava começando a fazer massagem, o aparelho e a órtese também. Porque a órtese eu faço ela todos dias, porque eu tenho que andar, porque eu não agüento, porque eu tenho a sensibilidade, tenho sensibilidade no corpo inteiro - foi só a parte motora, quer dizer, num ponto é bom e num outro ponto é uma cacetada ... porque eu sinto dores no corpo todo ... porque se eu fico muito na cadeira começa a doer a batata da perna, começa a doer o quadril, começa doer o ossinho, começa a doer as costas. Aí começa, aí eu tenho que andar, duas ou três voltas, fazer o movimento para esticar todo o corpo. Se não eu não agüento, e tem que fazer o aparelhinho para não dar problemas de atrofiação e nem voltar, a espacidade, porque essa, se voltar meu Deus do céu, e tem que fazer a massagem por causa da musculatura também porque ela está parada, então a musculatura ... tudo, não cedeu nada, graças a Deus não cedeu um milímetro, em cinco anos, eu passo todo mês, o médico ele mede, para ver se tem alguma coisinha. Nada. Mas também eu trabalho. Òs vezes eu tenho vontade de não fazer nada, não vou fazer nada hoje, mas aí já vem aquele negócio na minha cabeça, e se você não fizer ... aí sou obrigada a fazer."

Enquanto as experiências são realizadas, só the resta esperar. Neste caminho a sua atuação é muito limitada. a ação cabe ao outro, a ela só a expectativa da cura.

"Então aí foi isso daí. Aí fui fazendo isso daí, aí voltei para casa, aí eles estão em teste com quatro canais, que vai um passo assim na recuperação, porque esses dias ele me telefonou e falou ... Disse que uma pessoa ... que fez essa operação tinha uma musculatura boa, uma criança, porque tem vários ...tanto a paraplégica, o tetra tudo tem vários tipos né ... e esse menino que fez, ele tinha a medula dele, era toda molinha, daquelas pessoas que não tem o pêndulo, a firmeza, porque no caso, você, você tem firmeza. Ela era toda molinha que nem uma bonequinha de pano, aí eles foram fazer um teste, porque eles estão fazendo o teste na parte mais difícil, ai eles foram fazer um teste, o menino não agüentou, aí o plano foi pra cucuia.

Mas infelizmente ... ele falou se, se uma parte foi pra cucuia, mas eu, outra, a gente vai. Infelizmente a morte de um, vai ser o sucesso de muitos outros, porque nós vamos fazer experiências. $O$ que aconteceu? $O$ que foi que rejeitou? Então estou esperando esses quatro canais, tô fazendo aqui em casa, e tô esperando todo dia que a operação dê certo."

Essa espera congela a sua reinserção no fluxo do tempo. Edna, algumas vezes, tem dificuldades na utilização do tempo presente ou passado: "Gostei não, gosto", "chamava não, ainda está vivo". Não está claro o que pertence ao agora, o que vem do passado e continua hoje, o que já findou. E o futuro? Parece não haver menção ao futuro, exceto expectativas da ação alheia. Só há o tempo da recuperação das coisas do passado que, pela paralisia ou desuso, perdeu. Na verdade, Edna não parece conceber perdas definitivas. Espera reconquistar-se pelo 
trabalho cotidiano, por não se acomodar ao "status quo", por ansiar o máximo. Não se trata de desejar o novo, o futuro, o que ainda não viveu, mas recuperar os movimentos, a rotina anterior.

Trabalha o próprio corpo tal como um músico exercita-se no seu instrumento, ensaiando a partitura que tocará em breve.

Enquanto espera, ensaia um discurso autoconsolador. A espera gera um tempo de sobra com o qual pode observar a vida, as pessoas, os gostos das coisas. Dá-lhe uma perspectiva de sobrevôo. Ò margem do ritmo dos acontecimentos reflete e pesa as perdas e ganhos.

"Moro, eu e minha mãe, e meu irmão, antes do acidente também, graças a Deus, minha mãe foi meu anjo da guarda. Oh! meu Deus! pela fase que eu passei, porque é assim! Quando acontece alguma coisa com você, você tem um monte de gente ao seu redor, mas ah! ah! minha filha! pra cuidar de você!!! nem namorado, nem marido, nem ninguém, apesar de ter pessoas que têm sorte, eu vi muitas pessoas que estavam casadas e deu sorte, e tem outra que não deu.

Eu fui casada, já estava mais ou menos separada quando sofri o acidente. Aí quando eu sofri o acidente e que. ele foi embora de vez. Então, mas tinha a minha amada mãe, que foi ali, né comigo. Graças a Deus. não tenho... não tenho nenhuma coisa, lógico que você vai adquirindo. No começo o mundo caiu em cima de você. Eu tinha, no começo ... no caso, quando eu voltei do hospital eu falei: 'Vou destruir tudo, destruir tudo!' Você acredita: roupas, sapatos, essas coisas de parte pessoal, acho que tudo, tudo, tudo, parecia que a Edna morreu, destrui tudo. Acabou a Edna, aí aos poucos eu fui levantando, fui adquirindo um monte de experiências, com tanto que as pessoas falavam assim, puxa mas, coisas assim, acidente, desastre, digo desastre, na maneira global, para não falar ..., mas você sabe que você adquire um monte de experiência, um monte de coisas boas, pelo menos pra mim, por incrível que pareça, esse acidente, não houve coisas assim tão ... houve, lógico, $\mathrm{Oh}$ ! arrebentou um monte de estruturas tudo, mas eu ... pra mim não houve tantas conseqüências muito graves, eu tive nossa Ele fechou uma porta, mas Ele abriu um portão assim enorme para mim. Sabe! porque depois disso, pelo menos eu posso falar, os meus amigos são meus amigos, eu posso falar de boca aberta, sabe! De boca cheia também, são meus amigos, eu tenho amizades. Antes eu não tinha, sabe! Você vê um monte de coisas assim, você tem mais tempo para pensar, você tem mais tempo para ver, tem mais tempo pra você adquirir mais experiência, porque você tá ... Quando eu tava boa ... eu digo antes do acidente, eu não tinha muito tempo pra parar, pra pensar, para ver o vizinho, para ver isso, pra ver aquilo. Hoje eu já tenho tempo. As coisas pra mim é mais substancial, mais assim saborosa, eu saboreio com mais prazer, cada coisa que eu faço eu saboreio melhor, porque eu tenho mais tempo, talvez seja isto. A experiência também que faz você enxergar as coisas, os amigos, família, também pessoas que não tinham contato nenhum com a minha família, primos que nunca conheci e acho que nem tinha visto, 
quando soube aí voltou, vem sempre se reunir, quer dizer sabe, uma coisa e você perder uma coisa e você adquirir outra."

As reconquistas e as aquisições são pontuais, como por exemplo, quando recupera a capacidade de realizar os trabalhos domésticos. Uma fração da sua condição de mulher é aí recolocada. Já a questão afetiva, o casamento/a separação, ou a possibilidade de outros encontros e desencontros amorosos não se põem até este momento. Há uma certa estratificação no que precisa e pode ser retomado. É preciso poder mover-se para depois arrumar a casa. É preciso ser capaz de cumprir seu papel feminino domiciliar para pensar-se trabalhando fora.

"O trabalho é tudo, porque o problema é você andar, mas a tua cabeça, os teus movimentos é que faz tudo, não tem nada a ver. Mas é dificil você encontrar um lugar para trabalhar ou então encontrar o serviço, ou a boa vontade do povo ... o povo tem tanto preconceito de não dá emprego ao deficiente, onde eu vejo que não há também nenhum problema. Porque no caso do computador - por causa que a minha área tá certo a minha área já era agitada. Subia, descia tudo, mas a minha área de secretaria eu posso fazer alí, não posso ter todos os movimentos no caso, subir, descer, marcar reunião, todos esses negócios. Mas a parte mais burocrática de empresa assim, que a minha área é administrativa, a parte mais de controle dá pra fazer sentada ou mesmo de algum lugar assim pra fazer, atender telefone, marcar uma reunião, fazer isso daí, dá muito bem, e mesmo se fosse um prédio, se tivesse elevador também.

$\mathrm{E}$ até restringe um pouco a gente, porque a gente não tem como expandir. $\mathrm{E}$ alí fechadinha, quer dizer, você vai num teatro não tem condições de subir, por causa da maldita escada. Eu fico louca da vida, então você fica toda hora pedindo pra uma pessoa pra te ajudar, eu pelo menos não gosto, só se for um caso muito assim ... o máximo meu, aí eu peço. Eu gosto de sair assim livre, que eu possa ir a qualquer lugar, não gosto de depender muito, sou meia chata com isso, não gosto que ninguém carregue minha cadeira, mexa. Sabe, sou meia chatinha, mas se eu não fizer isso daí, eu vou ficar acomodada. Eu vou me acomodar, no caso como era antes: Mamãe vamos para alí, mamãe vamos para cá, mamãe faça isto, faça aquilo'. Quando eu consegui me libertar, consigo empurrar a cadeira, agora até hoje eu tenho um pouco de medo de sair muito na rua, por causa dos paralelepípedos, dos buracos, e um monte de coisa, porque aqui em São Paulo é uma coisa. Tem lugares que você anda, eu quando eu ando, eu morro de medo, porque a cadeira é leve e pum!, caí, eu morro de medo disso daí. Mas também não me incomodo de ir pra nenhum lugar. Já quando alguém me convida: vou pra tal lugar: 'tem escada?' A primeira coisa que eu pergunto. Se tem, tchau. Ah! mas eu ajudo, não! não gosto. Pra eu ir num lugar e me sentir assim forçada, eu não gosto, quero me sentir assim bem.

Eu trabalhava na companhia L... B... Eu trabalhei há muitos anos lá, eu era secretária executiva, lá na Paulista. Aí depois acabou. Aí mas até agora eu fico procurando de tudo, mas é muito difícil, então você fica assim meia rejeitada, é uma 
coisa meio ... né? Porque você sabe um monte de coisa, eu no caso, principalmente a minha área, a minha área, expandi tudo, minha área era administrativa. Você sabia! xerox, telex, todo tipo de telefone também, PBX, PABX todos esses negócios, com micro, com um monte de coisa que você pode fazer, meu Deus do céu! Uma área assim super expansiva. Mas ninguém dá uma chance para você. Já tentei várias vezes lá na secretaria tudo, mas é muito dificil emprego. Eu nunca fui no E. E.* eu nunca fui lá, eu sei que eles tão fazendo uma colocação lá, só no caso são 6 anos parada. Eu vou ter que ... mas é uma coisa assim mesmo coisa de dirigir, você pegou aqui, é uma questão de segundo, só pra você ... mesma coisa a máquina, tinha bastante tempo que eu não pegava, aí você vai pegando, você vai adquirindo habilidade de que você tinha antes, é uma coisa assim, é só você olhar e ... mas eu vou lá, me falaram isto daí que eles tão abrindo, pegando um monte de firma, diz que agora as firmas ... tem que ter uma porcentagem de deficientes físicos, então eu preciso ir lá, vou bater meu currículo e vou lá. Já me falaram do Posto da Brigadeiro. Também estão fazendo colocação, eu já escutei isso daí."

Neste momento, Edna não pode se decidir ainda por sair de casa na cadeira de rodas. Esta condição ainda the é extremamente limitadora. Há degraus por toda a parte, situações de trabalho difíceis e empregadores preconceituosos. Ela mesma não pode pedir ajuda e a idéia de buscar serviços voltados às pessoas deficientes the parece estranha, por que, por enquanto, deseja andar e não, movimentar-se, anseia por não estar no lugar que ocupa.

* Centro de Convivencia e de Cursos para pessoas deficientes. 


\subsection{MORTE E FRAGMENT AÇÃO: A REVTT ALIZAÇÃO PELO FEMININO A História de Nina}

Nina é uma mulher de 28 anos, mãe de uma menina de um ano e meio, na época da realização das entrevistas. É portadora de paralisia cerebral, apresentando um quadro de tetraparesia espástica, isto é, tem comprometimento motor nos quatro membros e de equilíbrio. Anda apoiada em uma bengala.

"Eu nasci de uma família pobre. O deficiente, principalmente mulher, quando nasce de uma família pobre, nós somos criadas, só exclusivamente para trabalhar, nós não temos muito valor, infelizmente. $\mathrm{E}$, se a mulher tentar deixar de ser aquela mulher submissa, que a família fala e ela escuta, ela não é boa para a família. Foi isso que aconteceu comigo. Logo no início, eu percebi que se eu tentasse ser eu mesma, eu ia ter muitos problemas com a minha família. De menor, eu conseguia controlar. Eu parecia, perante eles, muito fraca, muito frágil. mas eu acumulava, sabe, dentro de mim. Minha cabeça, ela sempre estava trabalhando um jeito de sair daquela situação. E me cobravam, de vez em quando falavam pra mim: 'Nossa, você é muito pacata, e aceita'. Mas eu ficava quieta, eu falava: 'É, é a situação e assim que eu conseguir realmente tentar virar a mesa', então, aí, foi um pouco mais difícil ..."

Nina, ao se apresentar, situa-se, primeiro e antes de mais nada, como nascida de

uma família pobre. A essa referência primeira a uma situação social, ela agrega duas outras condições determinantes: deficiente e mulher. A condição de deficiente é a mais generalizada, na realidade, é uma categoria: "O deficiente". Inserida nesse contexto social como pobre, deficiente e mulher, proclama sua indignação com a prescrição familiar de desvalorização social e conseqüente necessidade de submissão. Crê que a família espera dela um trabalho silencioso. Mas que tipo de trabalho? Provavelmente, o trabalho destinado às mulheres pobres, o trabalho doméstico, rotineiro e dentro de casa, um trabalho socialmente desvalorizado, ao mesmo tempo, "adequado" e que realce os limites e deficiências do indivíduo.

Nina se apresenta como vítima inconformada de uma situação familiar e social, ao mesmo tempo em que a urdidura de sua história será o processo de "virar a mesa" ...

Há um outro início dessa história, um início mais pessoal e com uma 
interpretação peculiar: - a instalação da deficiência como conseqüência de uma injeção aplicada em lugar errado.

"O meu caso começou com uma injeção que eu tomei. Eu tomei a ... a ... e eu tive em seguida ... me deu o problema. No outro dia, minha mãe falou que eu já não consegui levantar, porque eu andei com nove meses.

Minha mãe falou que foi incrível, eu comecei a andar cedo, muito cedo mesmo, nove meses. Aí, eu peguei uma gripe, e dessa gripe eu fui tomar uma injeção comum, mas todos os médicos acham que foi aplicada no lugar errado, e atingiu o meu ... o médico chamou de ...lá no Hospital das Clínicas. Eu sabia um monte de coisas a meu respeito, porque eu conversava muito com os médicos. Ele chamou de "sistema cerebral", daí deu seqüelas. Eu não posso tomar café, nem nada líquido, até mesmo sopa. Òs vezes, eu tenho dificuldade de tomar sopa. Tem que ser algo bem consistente."

Apesar dessa explicação estar inserida no seu universo cultural, Nina busca legitimá-la a partir de uma aproximação com o discurso científico. Para saber de si, foi preciso conversar muito com os médicos, entender de "sistema cerebral" e "seqüelas".

Como exemplo dessas seqüelas fala da impossibilidade de tomar líquido. Essa impossibilidade deve estar ligada a diferentes níveis de explicações dessas vivências. Provavelmente, deve referir-se tanto à situação concreta da dificuldade motora para manusear os talheres, ou para a deglutição, como há também uma alusão a "fazer mal". Essas explicações tem um limite bastante tênue entre uma interpretação da vivência exterior, concreta e real e a tradução disto a nível imaginário, enquanto fantasia inconsciente.

Essa tênue delimitação entre real e imaginário ganha proporções impressionantes quando Nina fala de sua "morte".

"Depois que eu tomei a injeção, eu fiquei em coma, fiquei mais ou menos três meses em coma e, lá, na cidade onde eu nasci (que eu não sou daqui, eu sou de Charruar, lá de Pernambuco, que é um pouquinho atrasada) o médico atestou, três meses depois, que eu tinha morrido. Então, é por isso que eu te falei, que o meu nome tem uma história. Na época, eu não me lembro o nome que eu tinha. Eu era pequena. Dizem (minha mãe e meu pai falavam) que me chamavam pelo meu nome que, realmente, até hoje não me disseram qual era. Só que meu irmãozinho, que é encostado em mim, ele me chamava de Nina. 
Como o médico atestou que eu tinha morrido, então, eu passei a não existir, até mesmo o meu registro de idade, na sociedade, no mundo. Eu não existia mais, eu tinha morrido, pelo atestado de óbito que ele tinha feito. Agora, no final da história mesmo, minha família, quando eu morri, o que eles iam fazer? Me enterrar. Aí, eles fizeram tudo que era preciso e quase que eu fui enterrada.

Eu cheguei a ficar, das três da manhã até as quatro da tarde do mesmo dia. dentro do caixão. Quando eu despertei, faltava pouco tempo para me enterrar. Eu despertei dentro do caixão, eu era pequena, eu estava com dois anos na época, e aí ... foi desmanchado tudo. Inclusive, até hoje, eu tenho, eu sinto isso. Minhas pernas chegam, em certa época, elas são geladas e elas suam demais, suam muito. Eu lembro que, até os cinco anos, minha mãe me colocava em pé, me sentava numa janela com os pés dependurados. Eles pingavam de suor, mas eles eram frios, muito gelados. Onde eu ficava, ficava uma pocinha de água embaixo, de tanto que meus pés pingavam. Um dia, o médico falou: 'Olha, Dona Maria, a senhora não procura mais médico para sua filha, quando ela tiver de nove para dez anos ela vai se levantar e começar a andar'. E eu me lembro que foi na época que eu comecei a ficar em pé, pra tentar meus primeiros passos. Eu até conseguia ... me equilibrar bem. Não como eu estou precisando atualmente, porque eu preciso um equilíbrio maior, e a minha luta agora é achar um lugar que eu faça um pouco de fisioterapia, porque o meu caso está regredindo outra vez. Principalmente agora, depois do parto, eu percebi que eu estou com um pouco mais de dificuldade de andar."

É, sob certo aspecto, a declaração de uma autoridade externa, do médico, que a lança no mundo dos mortos, dos que deixam de existir. Mas, diferentemente destes, não restou no seu caso nem mesmo a lembrança do sęu nome.

Na realidade, Nina não fala de duas existências diferentes que se sucederam, de uma morte e uma ressurreição. Nina fala que viveu num estado intermediário: quando declarada morta ainda vivia e, hoje, viva, ainda tem partes mortas. As pernas geladas, mas que suam, são as seqüelas de um estado de indiferença, de um estado de indiferenciação entre estar morta e estar viva.

Para Nina, ser deficiente é ocupar esse espaço social e familiar do esquecimento, ou melhor, da não existência. Não se trata simplesmente de uma questão de limitação, essência do ser vivo e corpóreo, ser deficiente é possuir partes mortas.

Partes se perderam, há algo que se perdeu. Algo não nomeado, ou cujo nome caiu no esquecimento e hoje se ignora. O seu nome, dado por seus pais, não existe. $O$ que existe é um ser nomeado pelo irmão - que a chamava Nina - numa relação fraterna e, provavelmente, fruto de uma contração da palavra menina. Um nome que se constituiu a partir 
dessa relação entre irmãos. O seu espaço na relação filial é o da indefinição, da indiferença. É o lugar do negado, do esquecido, do sem nome. Na verdade, ela não ocupa o espaço de filha.

Raramente, Nina menciona a figura dos pais. Quando aborda uma relação de submissão, refere-se à "família", aos irmãos, sem fazer uma ligação mais clara com as figuras parentais. Sendo que a relação de submissão, constituída no outro pólo da autoridade, referencia-se mais freqüentemente a uma relação parental, Nina poderia apontar para as figuras de pai e mãe. Isto não ocorre. Há um sentimento difuso de submissão, sem ficar claro de que submissão se trata, submissão a quê, a quem? Parece referir-se mais a uma espécie de "limbo", no qual permaneceu, mesmo após esta morte imaginária. Trata-se tanto de uma morte como de uma vida parcial.

A morte aparece como referida a perdas: perdas de aspectos internos, perda da relação filial, da ascendência. A partir disso, instaura-se uma falha, uma falta, uma ausência de ligação que não pode ser resgatada. Ela perdeu a parte que a tomava inteira. O que se perdeu está morto e coexiste num corpo onde ainda restam partes vivas.

Nina fala de sua deficiência como uma amputação imaginária. Algo que foi extraído, apesar de nela permanecer.

Perdeu-se algo que legitimava seu reconhecimento enquanto filha. Sem este espaço, sem um nome, sem uma ascendência, o acesso ao nível simbólico fica estreitado. A cada interpretação da realidade, a tradução simbólica e a imaginária se tocam. Tocam-se em tantos pontos que a equivocidade do discurso salta flagrante e gera, no ouvinte, uma estranheza difusa.

Algumas vezes, esse funcionamento mental leva Nina a atribuir a algo exterior um poder mágico que pode, ao designá-la, determinar completamente uma situação no presente, paralisando-a, ou, no futuro, condicionando a forma e o início dos movimentos, de mudanças. O poder das palavras é concreto e gera realidade.

A aplicação de uma injeção a levou ao coma, o atestado do médico a matou, ao mesmo tempo que a sua palavra predisse o momento em que voltaria a andar. 
"Os médicos não tinham uma explicação para o meu caso, talvez por causa do tamanho da cidade. Uma hora, eles te chamam de doente e alí você fica. Muitas vezes, eu ouvia, mas aquilo não me chocava, porque eu nunca fui assim de me chocar com determinadas palavras muito graves. Mas eu, na minha cabeça, eu achava que eu não era doente. Eu lutava muito, pra demonstrar ... não, a minha luta passou a não ... vamos dizer, assim, eu nunca lutei contra os outros, mas contra mim mesma. Eu nunca aceitei que eu era uma pessoa doente. Então eu fazia de tudo, tudo. Antigamente, eu tinha uma frase pequena que eu falava assim: 'Eu só não sei andar, o resto eu faço tudo'. Eu tentava dizer pra mim mesma: 'Você tem que lutar, custe o que custar, nesse mundo que você está aí fora'. Aos poucos, eu fui percebendo uma coisa que, no meu ponto de vista, eu também não consigo entender, se é só pro meu lado, que eu vejo isso. Do outro lado, numas pessoas que eu também conheço, tem hora que eu acho, que o nosso maior problema não está na sociedade, o povo. A sociedade aceita a gente como nós somos. Mas a nossa família, vive com a gente diariamente, e cobra demais da gente. Então, muitas vezes, estou num debate e o pessoal fala na sociedade. E eu fico parada olhando, e eu fico imaginando: 'Será que ele não tem problemas na família?' Porque eu acho ainda que pior que a sociedade é a incompreensão da família. Porque você está aí fora e sempre uma pessoa olha para você estranho. Quantas e quantas vezes eu olhei para alguém também. Eu achava que ele tinha as orelhas grandes, ou que ele era grande demais, ou magrelo demais ou gordinho demais. Então, porque que o pessoal não pode me olhar também? Eu, eu tenho o direito de olhar, porque o pessoal não tem o direito de me olhar? Pensando assim, muitas vezes eu consigo mais ajuda, bem mais ajuda lá fora do que dentro da minha casa. "

É preciso haver uma luta, uma forte resistência a essa força exterior que rotula, paralisa e mata com "palavras graves", "Uma hora eles te chamam de doente e alí você fica". Entretanto, essa luta precisa ser travada ainda no campo exterior. É preciso opor-se à tendência à paralisação, à inação que coabita o próprio corpo.

Ò medida que Nina toma consciência da ação dos outros e da sua própria atuação ("eu só não sei andar, o resto eu faço tudo"), pode perceber melhor os poderes e limites do exterior, pode acolher o olhar das pessoas, porque percebe a reciprocidade. Ela também olha, repara e critica. A percep̧̧ão da reciprocidade desperta sentimentos distintos quer se relacionem à sociedade ou à família.

O olhar para o povo, para a sociedade, sendo uma ação que guarda certa distância e, portanto, não traz perigos concretos, possibilita uma aproximação e equalização das relações, aí e "pensando assim", Nina crê poder obter muito mais ajuda. Já na família onde as relações são mais estreitas há riscos de perseguição, roubo e morte. A partir disso, Nina reagirá, 
distintamente no espaço público, da sociedade e no privado, da família.

"Fora da minha casa, eu tenho apoio total... Dentro da minha casa, eu não consegui o apoio. Na própria familia dele, ele não acha apoio. Tem um homem lá, que é o maior motivo da separação, que atualmente nós estamos enfrentando é, exatamente, a falta de apoio das duas famílias. Minha família, hoje em dia, quer a minha criança. Eu acho que eles não querem, não me querem, eles querem é a menina, tanto é que muitas vezes minha mãe falou: 'Se você quiser deixar a menina aí e ir com seu marido, eu cuido'. Aí é que eu despertei e percebi que querem a criança. Não me querem, tanto é, que eu posso sair todos os dias. Se eu quiser sair todo dia, eu posso sair e deixar a menina com eles que eles não se preocupam. Eles querem a criança. Agora, eles não pensam: 'Pôxa, a Nina, assumiu o caso mesmo'. Até o ano passado, eu era muito pacata, muito quietinha. Hoje, eu posso dizer 'eu tenho uma meta a atingir e eu vou tentar, não sei se eu vou conseguir, mas tentar, eu tenho o direito de tentar'.

Mas eu tenho uma irmã que é assim o que eu tenho de pior na forma de ser humano. Primeiro, ela não gosta de deficiente. A minha luta foi sempre rebater, quando ela queria me agredir. Ela nunca aceitou nem mesmo a mim. Ela vive dizendo, que certo foi o Hitler. Na época da guerra, diz ela, ele mandou matar todos os deficientes, as prostitutas e os homossexuais. Ela acha que são as três classes que têm de pior no mundo. A gente viver numa casa, ser deficiente, uma mulher deficiente, com uma pessoa assim ...

Eu dizia a ela que era uma eterna luta entre eu e ela, muito grande, eu e ela.

Ela atualmente está com $40 \ldots 43$ anos, parece. Parece que é isso, 43 anos. Ela não casou porque era muito mandona, e os meus dois irmãos, que casaram antes de mim, enfrentaram uma barra, talvez, pior que a que eu estou enfrentando. Ela sempre, quando uma criança ia nascer na família, ela achava que o certo era a mulher deles fazer um aborto. Mas, ele (J...) está longe por causa exatamente dessa minha irmã.

Ele é de uma família mais pobre, vamos dizer assim. Porque a casa de Itaquera, ela é muito mais ... mais humilde, vamos falar o português claro. E onde eu moro, a minha posição, perante a posição da família dele era muito boa. Logo no início, minha irmã falou pra todo mundo, ele estava interessado em mim por causa do dinheiro. Uma vez ela falou isso, falou várias vezes, que cheguei nele, porque eu sou muito assim, eu olho a pessoa e falo: 'Vamos conversar cara a cara, se doer você me desculpa' e eu expliquei pra ele o que a minha irmã estava falando, o que ela achava. 'Te dou um tempo pra ver se é isso mesmo que você está pensando. Você está até inconscientemente matutando qualquer coisa'. Aí, ele se ofendeu comigo e, claro, se ofendeu muito, muito mesmo, que eu fiquei até chateada com a coisa, mas aí ... tudo bem. Mas a família dele, os amigos dele, eles não deixavam ele em paz. Na época do meu casamento, veio na minha casa um amigo dele que estudou, não com ele, mas com as irmãs dele, e o cara viu que com muito sacrifício, nós conseguimos uma televisão, um isso, um aquilo e eles achavam que era muito. No dia do casamento, o pessoal percebeu que eles olhavam muito as coisas dentro da casa. Então, meu irmão me chamou, e falou: 'Olha Nina, ai tem algo errado. Eu estou vendo um rapaz constantemente olhando as coisas'. Eu até acabei a festa um pouquinho antes do normal. Era mais ou menos uma hora da manhã, quando eu falei: 'Olha, vamos acabar porque minha mãe está cansada'. E ficou só o pessoal meu amigo e o pessoal mais amigo dele também. Quinze dias depois entraram lá em casa. Assaltaram a minha casa, a casa lá onde eu moro. Agora o 
mais interessante, a pior parte: quando entrou, foi esse rapaz que entrou, ele e mais dois amigos dele. Quando o J... chegou do serviço. Quando eu casei, eu já casei grávida, estava grávida de um mês. E ele, cada vez que ele entrava, ele me pegava e falava: 'Você teve enjôo?' Todas aquelas perguntas que normalmente o pessoal faz. Eu estava vendo um filme, eram umas nove e meia da noite. Jefferson entrou, me beijou e falou: 'Senta ai'. Eu falei. 'Espera aí que eu vou terminar de ver o filme, depois a gente conversa. Eu tentei fechar a porta e só encostei, quando eu acabei de encostar, o Jefferson se sentou, os três caras entraram atrás dele. Aí, você diante de três caras armados ... até hoje a coisa mais engraçada é que eu sei quem foi, mas eu não conseguiria reconhecer. Mas a arma eu reconheceria, porque foi o que mais eu olhei. Agora, minha irmã se apoiou em cima disso, porque o rapaz mora, morava na mesma rua. Sabe o que ela falou pra polícia? Que eu e o meu marido planejamos o assalto. Eu falei para ela: 'Tudo bem ... você não gosta de deficiente, mas também você não precisa exagerar'. Aí durante esse período, eu cheguei até ir a vigésima primeira, ela ligou pra vigésima primeira e mandou os policiais irem buscar na casa do pai do Jefferson, as coisas que eles tinham roubado.

Eu passei por cada coisa ... E a idéia dela era só uma: matar a minha filha. Ela queria de qualquer jeito que eu fizesse um aborto. Então, pra que eu não ... para que ela não conseguisse, eu fiz uma verdadeira ... eu fiquei uma semana na casa do meu irmão lá em Arujá. Aí ela descobriu onde é que eu estava e foi lá. Eu saí de Arujá e fiquei três meses morando na casa da mãe do Jefferson, depois eu fui para casa do meu tio, em Jandira, porque ela descobriu onde é que eu estava e eu fui pra casa do meu tio. Fiquei 15 dias lá. Um dia eu resolvi esquentar ela. Nessa altura, a criança que já estava bem desenvolvida, o médico me falou que não tinha mais perigo de eu perder ela, que eu poderia encarar qualquer problema. Aí eu falei: 'agora, eu encaro ela'. Aí eu fui atrás dela. Aí eu falei: 'agora chega de eu correr. Agora quem vai correr vai ser ela'. Aí eu cheguei, porque tem várias coisas erradas que ela faz atualmente. Coisas terríveis que eu tenho vergonha de dizer, hoje em dia, que ela é minha irmã, tenho muita vergonha mesmo. Ela faz muita coisa mesmo, coisa baixa, que atualmente a sociedade faz demais, as pessoas aí fora fazem tranqüilo e acham que é normal. Eu só falei pra ela: 'Olha C..., na hora que você falar qualquer coisa de mim ou do Jefferson, nós vamos, não lá na vigésima primeira, vamos na polícia mais séria. Aquela do Governador que eles estão querendo saber onde é que está indo o dinheiro do contribuinte que você fica escondendo'. Ela percebeu que eu encarei ela, que eu ia encarar ela.

Consegui provar pra polícia que eu não tenho nada a ver, meu marido não conseguiu, porque na hora em que eles foram me pegar na casa dele, pegaram ele primeiro. Mas na hora que eles foram me pegar, eles falaram que era a C... que tinha dito que foi ele. Se ele não assinasse os papéis que tinham lá, eles iam me deixar presa. $\mathrm{E}$ eu estava de cinco meses de gravidez e o cara achou que eles iam me prender mesmo, porque o próprio delegado já estava muito chateado com a C.... Ela todo dia enchia o saco dele. Ele falou pra mim e pro meu marido: 'Olha, eu tenho que prender alguém, porque se eu não prender alguém, ela não me deixa em paz'. Ele até pediu desculpa pra nós. 'Desculpe, mas eu tinha que prender alguém e ela mandou prender a própria irmã', que no caso era eu. E, ele falou pra mim: 'Olha, você podia processar ela duas vezes. Uma, por ela dizer que você é que estava com as coisas e outra porque ela queria tirar a sua criança'. Foi uma briga muito feia. Eu cresci demais. Pensando bem, eu tava grávida e tava na casa dos outros ... mas lá no fundo, a sensação de você estar com o seu filho no colo, compensava tudo.

Na novela das oito, tinha uma mulher que perseguia o marido da filha. Toda vez que o rapaz tentava arrumar um emprego, ela estragava. E a minha irmã fazia isso. Todas as vezes que nós conseguíamos um local, ela conseguia descobrir. 
Nisso foram passando seis meses praticamente sem quase nada pra comer, eu tentando me segurar com aquela criança, o que eu comia era mais pra criança do que pra mim. Eu tinha muito medo. Eu passei, vamos dizer assim, eu passei fome, passei muito frio, porque quando eu saí de casa, saí numa época mais ou menos quente, saí no mês de abril. E eu levei numa mala pequena a roupa, porque eu não calculei que eu fosse passar tanto tempo. Eu pensei assim, minha irmã, ela logo vai tentar ficar calma, aí, a gente conversa, porque a minha meta, era só salvar a criança, eu não queria perder essa criança de jeito nenhum. Eu passava tudo que tinha de passar, só que eu não queria perder ela, a criança. Fiz esse rodízio todo, fiquei na casa de um, de outro, do outro, só pra evitar ela de ... porque quando a gente está esperando nenê, qualquer coisa é motivo pra gente abortar sem querer, muitas vezes e sem querer, e aquilo eu não aceitava, perder minha filha, meu filho, eu queria, sabe, pra mim tala bom. Mas na casa do pai e da mãe do Jefferson, a coisa era muito difícil, muito mesmo. Eles têm muito filhos. Minha vida mudou, mudou demais. Eu passei a ficar dentro de um quarto com três crianças, cada uma mais danadinha que a outra. Levantava de manhã e não tinha o que comer, a criança queria comer mas eu não tinha o que comer, eu bebia água. Meio dia, eles botavam só arroz e feijão pra comer, só isso. Eu passei três meses comendo só isso. De noite, era arroz e feijão, outra vez. E essa vida eu levei. Quando a minha irmã ligava perguntando se eu estava bem, eu sempre dizia que sim. Mas eu peguei gripes terríveis, pois, vamos falar o português claro, eu estava debilitada. Por isso que eu tinha muito medo. Até não engordei, eu estava magrinha, quase não parecia que eu estava grávida. Porque eu não comia nem de dia, nem de noite. Agora, quando eu deitava, muitas vezes, eu começava a lembrar das coisas, eu ficava pensando, puxa vida, por que comigo? Eu nunca tentei fazer essas coisas com ninguém. Por que a minha irmã, justo comigo que ela fez isso?

Como ele assinou aquele processo, nós íamos até o Fórum. Sempre encontrávamos ela lá, sempre ... Era a pior situação da minha vida. Você entrar, encontrar a tua mãe, a tua irmã, tudo pra prender teu marido. Sabe, ela fazia verdadeiros espetáculos lá no Fórum. Ela fazia espetáculos. O mais engraçado era que o rapaz que entrou lá em casa passava por mim. Passava preso, porque ele foi preso em flagrante. Quando ele correu com as coisas, a Rota ia descendo a minha rua. Ele se assustou, jogou as coisas no chão e correu. Quando ele correu, a Rota correu atrás, porque o policial já sabe: correu ... é alguma coisa. Correu, pegaram ele. Ele nunca falou para o policial que foi o Jefferson. Só que o delegado falou pra mim e pro J..., que ela pagou pra dois rapazes, dois policiais, baterem nele, até ele dizer que tinha sido o J..., o próprio delegado falou: 'Otha ela faz isso, ela chegou a bater nele. Ela mandou esses dois policiais segurarem o rapaz e bateu nele pra que ele dissesse que era o Jefferson. Eu falei o que ela fez. Que seja o que Deus quiser, porque, agora, na época eu tinha feito o ultrassom, falei: 'Minha fillha não vai morrer, mas eu não sei se você vai se livrar do processo tão rápido quanto meu marido vai se livrar'. Eu sei de muitas coisas dela, muitas coisas terríveis, desde tráfico de drogas, a nota fria, assassinatos. Sabe, quem tem um passado como você tem, você não devia nem mexer com as pessoas, e ainda mais com a tua irmã. Você, olha, eu, eu mesmo, eu vou te processar duas vezes. Assim que a criança nascer, e eu tirar ela do convívio de vocês, eu vou entrar com esse processo'. Então ela está esperando dois processos. Eu sempre mando dizer pra ela, porque eu não falo com ela: 'Olha não deixa ela esquecer que, mais dia menos dia, ela vai receber dois processos, só quero que a minha filha cresça, que a minha filha seja forte, tá'. Perante tudo isso, nós ainda estamos enrolados com a polícia. Nós não, ele né?.

A C... conseguiu comandar todos. Olha, para o meu irmão ficar contra mim, ela deu uma pick-up, esse carrinho que vale agora em torno de três milhões. Pra minha 
irmã, a Sandra, ela deu um Gol. Ela, assim, vamos falar o português claro, com o que ela rouba, ela tem muito dinheiro, tá?. Pro meu irmão de Arujá, ela deu uma casa. Então para a Andréa, a Andréa tem 19 anos, mas ela trabalha demais e o namorado trabalha. Então, com muito sacrifício, eles conseguiram comprar um carro. Então, eles não querem nada dela. Pros outros que eram mais fracos, I... queria um carro, ela deu; a Sandra também queria um carro, ela deu um carro. $O$ meu irmão queria muito uma casa. Ela deu a casa. Então, dando isso pra eles, eles não tinham condições de ficar contra ela. Era mais fácil quebrar a corda pro meu lado. No dia dos namorados, no ano passado, me lembro que eu fui ver o meu marido. Isso foi no sábado. O Dia dos Namorados, parece que ia ser no domingo. Na segunda-feira eu tentei voltar para casa e meu irmão me proibiu. Ele falou que eu não voltava mais para aquela casa. Eu chorei muito. Foi a única vez que me atingiu, mas me atingiu forte. $E$ eu fiquei um mês sem voltar pra casa. Um dia ele me ligou lá onde eu estava, e perguntou pra mim: 'Você não vai voltar pra casa, não?' Eu falei: 'Não, I..., porque me falaram que você não queria mais que eu voltasse pra dentro da casa que eu moro, e se você, hoje, comanda a casa, eu sei que não é uma boa'. Eu falei: 'Eu sou casada ainda, eu tenho mais é que ficar do lado do meu marido'. Aí ele cedeu. Ele disse, 'eu falei aquilo numa hora de raiva'. Eu falei: 'não, I..., fica na casa, numa boa, que eu estou bem aqui'. Mas ele mesmo, ele ia me buscar. Ele falou: 'Nina, volta, que eu vou aí ficar um pouco perto de você'. Um mês e pouco, a minha mãe foi lá onde eu estava, e falou: 'Nina, volta', porque onde eu estava ... é feio dizer ... mas eu estava passando fome. É feio mesmo.

Eu não confio mais no I... Não confio mais na Sandra. Não confio no Tico, que é o meu outro irmão lá, que tirou a casa. Eu só confio na Andréa. Ela é a minha irmã caçula, está com 19 anos agora, e ela olhava pra mim, no meio daquele desespero todo. Porque pra mim foi um desespero muito grande, apesar de eu não sair assim gritando, foi assim um impacto muito forte. Você saber que a sua irmã mandou te prender, a minha irmã foi em todas as casas dos meus parentes e falou que eu que tinha mandado entrar lá. De repente, na rua que você mora há 17 anos você passa ... ela chamava o meu marido de bandido, na casa do meu irmão, ela gritou que quem acudia bandido, era bandido também. Ela chamou meu irmão de bandido, também. Então, para mim, foram palavras que, até hoje, eu não confio. Têm coisas, que não falo com ela. Mas ela faz qualquer coisa pra tentar falar comigo. Então, nessa época, minha irmã falou assim: 'Nina, percebe uma coisa, como Deus é bom. Ainda sobrou eu, Nina. Eu estou aqui, eu estou aqui, eu estou do seu lado'. Ela não consegue fazer a minha cabeça, porque ela fez a cabeça de todos os outros, todos."

É no seio da família que Nina irá nutrir um profundo e não-nomeado sentimento de raiva: "De menor, eu conseguia controlar, eu parecia, perante eles, muito fraca, muito frágil, mas eu acumulava, sabe, dentro de mim".

Essa raiva, identificada como força motriz, levará Nina a deslocar-se da condição de morta-viva, de simplesmente deficiente para a condição de mulher deficiente.

O episódio do roubo e da acusação, a perseguição pela irmã, são, ao mesmo tempo, expressões do deslocamento de suas próprias dúvidas e acusações digiridas ao marido e uma oportunidade de reagir, de responder agressivamente, de mover-se pela raiva. Uma 
situação extremada como essa, aliás, como parecem ser todos os aspectos de sua vida, exige a radicalização de suas capacidades e mecanismos de defesa. Diante de circunstância tão conflituosa, ressurge um funcionamento mental onde os mecanismos de cisão e projeção são exigências para a manutenção de algum grau de equilíbrio.

A percepção da reciprocidade das relações, o contato com sua raiva e indignação pela indiferença familiar e social constituir-se-á num primeiro passo para reconhecer-se mulher. Essa percepção irá apontar para um movimento de aproximação, de equalização das relações, principalmente com as irmãs. Para Nina, pertencer a condição de mulher, ainda que reconheça aí também a desvalorização social implícita, significa muito mais que ser deficiente, é deixar de ser ignorada e apropriar-se, talvez, de um signo de vida e identidade.

"Eu já tinha namorado com o Newton, com o Augusto, com o P... Namorei com o G... que, de todos, era o que de mais me aproximava. Eu não posso dizer pra você que eles chegaram a falar: 'Nina, vamos fazer tal coisa', que eles não chegaram, não. Eu não sei se, de algum modo, eu mantinha eles longe. Não longe de mim com eles, mas pelos papos que eu mantinha sempre com eles, eles percebiam que eu era diferente. Uma das coisas, que todo mundo percebe, é que eu não gosto de ficar falando palavrão. Acho que a mulher quanto mais solta, mais cria problema na cabeça dos homens e cria para ela. Só pra você ter uma idéia, eu sou uma pessoa que você nunca vai ouvir falar nenhum palavrão, nunca. Você pode passar dez anos, mil anos comigo e você vai falar: 'Nina, eu nunca ouvi você falar tal coisa'. Não porque eu ache feio. Não porque eu ache que é pecado, não. É instinto. Cada palavrão tem uma outra palavra que eu posso substituir. Aí, todo mundo percebe isso em mim e, desse jeito, eu também sou eu, Nina, eu, sabe? Quando a pessoa critica um outro, é porque quer ser igual. O outro, gostaria de fazer igual. Foi isso que eu mais senti nas pessoas que me criticaram. Quando eu falei pra Lúcia: 'Eu estou esperando neném'. Ela disse: 'Você jura?' Quase estourou o meu ouvido o grito que ela deu: 'Jura, Nina, você vai?'. Eu falei: 'É, por que? Ela: 'Não credito, você vai ter coragem de fazer mesmo?'. Eu falei: 'Não é fazer, já fiz'. Mas ela nunca chegou ao ponto de me criticar, nunca.

Vai fazer dois anos, eu viajei pro Nordeste, porque eu havia saído de um namoro meio bagunçado. Eu namorei sério só três vezes. O primeiro era deficiente, o segundo não e agora o Jefferson, meu marido, é deficiente também.

Quando eu resolvi casar, quando eu casei, um dia eu estava parada e eu comecei a pensar. Eu não acho que eu fiz uma besteira, perante muita gente, porque o meu marido também é deficiente. Algumas pessoas acham que nós fizemos algo errado, mas eu não acredito nisso, porque tudo que você faz e você assume, não é errado, muito pelo contrário.

Quando eu voltei dessa viagem, ao Nordeste, encontrei o Jefferson lá no Centro Social. Conheci ele lá. Como eu já estava meia ... eu via o mundo assim ... eu só queria 
lutar, no caso, sendo deficiente, eu enfrentava muita barra lá no Centro Social."

Há uma tentativa de caminhar em direção à uma síntese, superando a

fragmentação da condição de deficiente e de mulher, para a condição de mulher deficiente.

"Na época, eu estava dando aula lá com o pessoal, eu fazia um curso do Paulo Freire. Porque eu acho que o deficiente, pra gente atualmente, está muito difícil arrumar emprego na forma de uma escola. E eu tentava, falava pro pessoal 'é pouco tempo que nós temos, mas tenta, tenta aprender, tente de uma vez'. Eu tenho bronquite, muitas vezes eu ia com crise, mas eu nunca faltava, porque eu achava que não devia faltar. $\mathrm{E}$, foi num desses dias que eu encontrei o J... Aí, até foi engraçado. Na hora em que eu o vi, eu nunca tinha pensado em outra pessoa. Toda vez que eu estava dentro de casa, eu ficava pensando nele, mas nunca demonstrei, nem para ele, nem pra ninguém, que eu gostava dele, porque na época que eu conheci ele, ele estava de olho numa outra menina, que era minha amiga. E eu apoiava ela com relação ao namoro com ele. Aí foi quando ele percebeu que eu gostava dele. Ele veio falar comigo e, como ele estava namorando com a menina, eu falei: 'Sinto muito, mas minha amiga em primeiro lugar'. Minha amizade com a menina era muito forte. Depois, eles acabaram e então, eu comecei a namorar com ele. Mas até hoje eu paro e fico pensando: 'Ele pra mim foi aquela pessoa que eu sempre procurei. O que eu tenho? Eu era muito pacata e ele era muito mais ... ele era o encaixe daquilo que eu não era'. Isso que eu achava engraçado. Onde me faltava coragem, ele empurrava. Eu achava aquilo engraçado. As diferenças que, no final, levaram a ... Eu não consigo explicar. Sabe, o que falta nele encaixa em mim e o que falta em mim encaixa nele. Até hoje somos assim. Muitas vezes ele precisa falar uma coisa, ele me liga e fala: 'Olha, eu vou fazer tal coisa. O que você acha?' Então, eu acho isso legal, porque mesmo longe, nós estamos longe há uns seis meses, longe um do outro, ninguém conseguiu nos separar. A gente entrega nas mãos do mais forte. Eu percebi que o que segura nós dois não é uma criança, no caso a R... Criança nenhuma segura marido e mulher. O que segura é a vontade de estar mesmo perto. Eu perto dele, ele perto de mim. E ele está machucado. A menina completa, mas, assim, se seu quisesse sair, desviar dele, já teria feito. Se ele quisesse, também ele já teria feito. Era tão fácil, era só ele ligar para mim e dizer: 'Olha Nina, não quero mais nada com vocế'. Ou era só eu ligar para ele e falar: 'Olha J..., foi legal enquanto durou' e eu ia viver com minha filha numa boa.

Ele assinou os processos, um processo, e atrapalha demais um trabalho decente. Atualmente, ele está numa entidade que é o que tem de pior em matéria de trabalho para deficiente. Ele ganha por produção. Ele sai de casa quatro horas da manhã, pra não pegar o ônibus muito cheio, nem o metrô, e volta tipo nove, nove e meia da noite. $\mathrm{E}$ nessa vida ele está. Com esse tempo chuvoso. Ele tem a ... a perna que parece forte ... porque quando a pessoa usa muleta, cresce muito essa parte aqui, é muito alta, grande, dele. $O$ pessoal acha que ele é muito forte mas ele é muito fraco internamente. Ele pega gripe muito fácil. $O$ vento passou, o cara pegou uma gripe e com todos esses problemas que ele teve, ser preso, responder processo. Ele já tinha, quando ele era pequeno, problema de coração, que agora acentuou mais ainda. Vira e mexe ele tem problema. Ele precisa ir pro hospital, ele sai direto pro hospital. Não aceita a idéia que eu fique na casa da minha mãe, ele fique longe da filha, eu também. Eu vejo aquela menina crescendo, eu fico pensando: Deus precisa dar um jeito, a criança se apega muito às pessoas e como é que eu vou chegar um dia, quando essa menina estiver grande, e 
dizer: 'Olha, ele é teu pai. Ela não conviveu com ele, não cresceu com ele. E o que mais magoa agora, é ele não estar vendo o crescimento da filha. Eu vou à casa dele, da mãe dele de oito em oito dias, de $15 \mathrm{em} 15$ dias, porque eu não posso ficar saindo muito. $\mathrm{O}$ dinheiro que eu arrecado, com este trabalho de artesanato, só dá pra ajudar a comprar comida pra ela, porque o artesanato caiu muito, atualmente. Não tem aquele ... aquele valor, vamos dizer. O que está mais cotado hoje em dia é a comida. Eu só tenho que dar comida com o artesanato. Então isso está me deixando muito preocupada. São os dois itens mais pesados: é roupa e comida. Se ela cresce rápido demais, a roupa que eu comprei o mês passado, este mês já não está dando e isso está me assustando porque ele está neste trabalho e não ganha o suficiente para cobrir as despesas. Ele pega metrô, pega trem, nós não pagamos só o ônibus, mas ele não pega ônibus. Ele pega um ônibus só. Mas ele pega um metrô, um trem e um ônibus pra chegar na casa dele. Se ele tivesse apoio de qualquer um dos lados não estaríamos separados.

A minha família, eu percebi depois, fez uma jogadinha com um ex-namorado meu. Ele começou a aparecer lá em casa, a ligar, e a minha família encaixou. Ela quer muito que eu largue do meu marido pra ficar com esse rapaz. Inclusive, o rapaz é casado, tá separado da mulher. Eles pensaram que iam conseguir assim me separar do J... Ia dar um encaixe perfeito. Eu cheguei pro rapaz, conversei com ele e falei: 'Olha, o que eles estão querendo não é o mesmo que está batendo entre eu, você e o J...'. Porque, eles falavam para o P... que eu não gostava mais do J..., porque lá em casa eu nunca falo o nome dele. Eu nunca, mas nunca, toco no nome dele. Agora, eles começaram a perceber que, a menina parece demais com o pai. Então, eles chamam ela de Jeffersina. Então, eles passaram a falar no nome dele. Quando eles chamam ela assim eu só dou risada, fazer o quê. Eu acho que do meu jeito eu não converso muito dentro de casa. Eu faço um trabalho de artesanato, eles chegam eu estou sempre trabalhando, quando eu não estou com ele eu estou com a menina. Minha mãe mesmo, praticamente não cuida da menina, porque, é um barato, você começa a fazer coisas que você achava que você nunca ia fazer. Eu dou banho na minha filha, tranqüila, mesmo com a minha mão direita sem muita agilidade. Nunca eu machuco a menina, nunca machuquei. Você percebe coisas, que você achava que nunca iria fazer. Acho que, de viver assim só, porque eu vivo só numa casa cheia de gente, e é horrível isso, você estar assim, extremamente sozinha. Eu só converso com a R..., ou com a cachorrinha que a R... ganhou, a Carolina. Então, eu converso muito com as duas e respondo qualquer pergunta que eles me fizerem, mas eu não me envolvo nas conversas deles. Não que eles não queiram, e é estranho isso. Eles estão conversando, muitas vezes eu estou com a R..., eles falam: 'O que você acha, Nina?' Eu falo, 'não sei...'. Eu não quero mais me envolver, porque quando a C... fez isso comigo, só teve uma irmã que ficou do meu lado.

Eu, deficiente e ele, deficiente, a situação que eu estava enfrentando era tão grave que eu tinha medo que a criança nascesse com algum problema também. Quando a gente é deficiente e a mãe da gente não, encara com a gente, médico, tudo. Mas você já pensou, eu, precisando olhar minha filha, no caso também deficiente, eu não teria condições. Eu falava só uma coisa, eu quase nunca chorava ... eu só falava: 'Oh! Meu Deus, seja feito o que você quiser ... eu não posso criar a minha filha se ela vier deficiente. Mas se ela vier, vou gostar do mesmo jeito, eu não vou gostar mais, porque se eu tentar gostar mais, vou proteger. Eu vou querer gostar dela como ela é'. Aí eu fui levando o período da gravidez. Eu fiquei com ele até os seis meses, depois eu percebi que se eu continuasse com ele ia ser pior. Eu enfrentei ela, a minha irmã, ela ficou com um pouco de receio e saiu da casa da minha mãe. Atualmente, ela mora em Santa Isabel. Quando ela saiu, a minha mãe falou: 'Olha, Nina, vem e fica comigo até a criança nascer. Quando a criança nascer, você volta a morar com teu marido'. É isso que eu estou fazendo. Só que, no início, eu também tenho problema na mão direita, eu tinha 
receio de eu machucar a criança. Eu entrei num acordo com meu marido. Eu disse: 'vamos deixar a criança crescer um pouco. Quando ela estiver num estágio que não precise tanto de cuidados, de cuidados delicados de duas mãos firmes, e que segure-a ... Você continua trabalhando, consegue um cargo, consegue a casa, aí nós vamos ficar juntos, nós três. Porque, por enquanto, tem paciência, a menina é a prioridade na minha vida'. O Jefferson não gosta da idéia, ele fala pra mim: 'Pôxa, estou me sentindo só'. Eu entendo, agora eu entendo que eu e ela somos duas, e ele está só. Numa conversa que nós tivemos, eu percebi, e ele também, que nós não gostamos um do outro só por causa da menina."

- A gravidez e o casamento são para Nina uma tentativa de ousar o status de mãe, de aproximar-se da figura materna, superar a irmã mais velha que não tem filhos, não pode gerar e inveja essa capacidade, e, ousar o seu reverso, o resgate do lugar de filha. Sua filha pode se constituir no elo perdido com seus pais. Pode restaurar sua identidade de filha, de pessoa inteira. Pela gravidez, Nina esperou ressuscitar a menina não deficiente, embora tenha tido dúvidas sobre sua capacidade de fazê-lo.

Infelizmente, não o conseguiu plenamente. Almejava o lugar de filha e gerou um substituto a sua pessoa ... "não me querem, tanto é que eu posso sair todos os dias ... que eles não se preocupam. Eles querem a criança."

Apesar de sentir-se mais inteira porque sabe-se capaz de gerar e de defender-se a si própria e à criança, ainda restam dúvidas, fruto de aspectos ambivalentes da sua relação com a filha, quanto à sua capacidade de cuidar sem ferir: "Vamos deixar a criança crescer um pouco. Quando ela estiver num estágio que ela não precisa tanto de cuidados, de cuidados delicados de duas mãos firmes que segure-a ..."

Para Nina, o resgate da sua condição de mulher aparece como o caminho possível para tornar-se inteira. Esse resgate da feminilidade, primeiramente, é buscado pela posșibilidade da gestação e, depois, pelo casamento, pela relação com um homem. Diferentes significações da gravidez e do casamento explicitam-se, simultaneamente, no discurso de Nina e correspondem aos diversos momentos do processo de crescimento e desenvolvimento da Menina-Nina em direção a Nina-Mulher.

Em verdade, a possível designação da criança, anterior a sua "morte", como 
menina, apesar de não apontar para uma individualidade particular, já sinalizava para essa distinção primeira de gênero: tratava-se de uma menina-mulher. A "morte" e a conseqüente instalação da deficiência ocasiona um processo de contração dessa identidade primeira: a menina descaracteriza-se enquanto possibilidade virtual de tornar-se mulher, fica fragmentada NINA - e congelada nesta condição, torna-se um resquício de feminilidade em estágio infantil. A deficiência é esta condição que fragmentou e interditou o desenvolvimento da meninamulher.

A atualização da possibilidade de tornar-se mulher será perseguida pela gravidez, em um processo de identificação com a mãe, que significa a gestação de si mesma, dobrar-se sobre si e ocupar, simultaneamente, o lugar de mãe e de filha dela mesma, menina-não deficiente e mãe-mulher inteira.

Ao lado desse processo de identificação e da tentativa de (re)-filiar-se, também deseja romper com esta família primeira e constituir outra, uma nova família onde possa ter um espaço diferente do da pura submissão.

A relação com J... e o casamento são meios para alcançar isso. Dessa forma, essa relação comporta também diversas interpretações. Representa tanto a necessidade, consciente, mas muitas vezes menosprezada, de um "inseminador" para poder gestar, como alude à idéia de objeto de "encaixe" perfeito. O encontro com esse homem que, muitas vezes, parece-lhe frágil e com dificuldades de enfrentar a realidade de carência que vivem, ao mesmo tempo, é o que possibilita a ela recriar-se na criação de um novo ser.

Apesar da condição de mulher ser vivificadora para Nina, ainda restam as condições de deficiente e da pobreza. A conjugação desses aspectos pode levar a críticas por parte da sociedade, principalmente porque são geradoras e agravantes da carência.

"Teve duas meninas deficientes também, que me apoiaram 'aí Nina, que bonito, que gostoso', mas as outras, virgens, criticaram. Teve umas mais feias, umas mais velhas, assim, umas feiosas, já de certa idade, que acharam aquilo bonito demais. Mas aquelas que estavam no meio termo criticaram. Tem a dona Josefa, que é deficiente visual, que me apoiou, que foi a que mais me apoiou. Aquela me apoiou. Toda vez que 
um homem, que eu fizesse xixi numa garrafa. Eu fiquei calada, na hora ele me desarmou. Eu falei pra ele que a mulher tem mil utilidades igual ao homem. Ele falou que não. Que se eu fizesse xixi na garrafa, eu era igualzinha a ele. Aí no outro dia eu chamei ele e falei: 'I..., você ontem falou isso e agora eu vou te falar uma coisa: me dá a garrafa, que eu vou mijar nela pra você, agora, depois que eu terminar, você vai ter um filho, porque você ainda é menos do que eu. Eu vou mijar na garrafa e ainda vou ter um filho, quero ver você'. O cara desistiu. Era uma briga, não era uma brincadeira, não. Porque antes, se a mulher fosse discutir com um homem, saía briga porque o homem sempre achou que era macho. Não estou falando que era uma brincadeira, era uma briga entre um homem e uma mulher. Briga feia, mesmo, que acabou nessa discussão: 'Você me dá a garrafa, me dá um tempo, que eu vou lá e mijo, e daqui a pouco, quero ver você ter um filho'. Daí ele olhou pra mim e falou assim: 'é Nina, crescemos, você tem uma filha e a briga continua'. E agora nós somos ... ele casado, eu casada, mas a briga entre a gente continua. Ele também casou e, coincidência ou não, cada um tem uma filha. Mas a nossa briga continua. Nunca brigamos atingindo, xingando, não. Mas ele sabe do meu ponto de vista que ele tenta respeitar. Ele tenta, porque homem não respeita ponto de vista de mulher não.

Ele tenta, ele faz um esforço muito grande, principalmente agora, porque agora eu tenho outra cabeça. Mas, uma vez, ele estava falando que eu sou uma pessoa que não fica criticando. Eu não tenho motivo. Eu sempre pensei assim: 'Se a gente critica, quer fazer e não tem coragem'. A gente ouve os papos, fulana está grávida, não tem pai ... fulana não sei o quê ... e eu passava e falava: 'olha o veneno ..."'

Enquanto mulher, a relação com as outras mulheres e os homens têm matizes diversos. O relacionamento com as outras mulheres explicita a preocupação com a crítica, atribuída á uma possível inveja destas. Uma crítica e autocrítica ligadas a "tipos" de mulheres existentes e a um comportamento "libertino", onde palavrões e relações sexuais fora do casamento são condenáveis.

A relação com os homens quando apaixonada é maternal e cheia de preocupações: "O pessoal acha que ele, J..., é muito forte, mas ele é muito fraco internamente. Ele pega gripe muito fácil". E quando não são constituídas pelos laços da paixão, são relações pautadas pelo embate e pelo desafio para provar-se mulher potente. É possível fazer coisas de homem sem um pênis e ainda poder gerar filhos.

Esse embate entre ela e os homens, apesar de não ser "brincadeira", não chega a ser uma luta de vida e morte. Esse risco, atualmente mais amenizado, continua presente na figura feminina familiar, que magicamente, pode recolocá-la na geladeira, no frio mórbido da indiferença. 
"Uma coisa eu soube segunda-feira e eu fiquei chateada com ela. Na terça-feira, eu vi ela, mas me deu vontade de pular e meter-lhe um cacete. Sabe o que a minha mãe falou que ela falou lá? O meu nome e o nome do Jefferson corria lá. Já te falei, né? que ela mexe com esse negócio de macumba? Só que quanto mais ela mexe, mais estraga. Eu fiquei danada e falei 'pô, quer fazer, vai fazer na casa dela. Não vem fazer aqui onde eu estou'. Porque a geladeira, é daquela que desgela por conta própria, mas ela não cai a água, não sei, parece que a água sobe de novo, não entendi até hoje. Então ela desliga toda noite e se você parar, você escuta o barulhinho da água. Aí ela botou o meu nome e o nome do Jefferson ali, e eu acho que a mãe devia passar um pano de vez em quando ali dentro. Aí a mãe estava limpando a geladeira e viu. Pegou o papel e abriu e aí chamou a Sandra e a Andréa e mostrou, e falou: 'olha o que a tua irmã está fazendo com a outra tua irmã'. Aí eu olhei pra ela, e me deu vontade de falar 'olha C..., vamos pro Polo Norte, porque lá é gelo puro, leva pra lá e põe debaixo de um iceberg'. E ela é cara de pau. Ela olha pra minha cara e fala 'você está bem?' e eu falo 'muito bem, obrigada, melhor é impossível' e essa foi a única vez que eu falei com ela em todos esses dias. Agora olha só a minha filha que tamanho que está. Não é pra gente ficar bem? Me deu, vontade de pular em cima e gritar: 'porque você fez isso?' É muito cara de pau, sei lá. É fogo, né?"

Ao lado dessas vivências tão ameaçadoras no seio familiar, no espaço social mais amplo, as relações interpessoais são menos tensas. Contudo, no espaço social, ainda é necessário posicionar-se, o que implica em um certo grau de tensão, mas, ao mesmo tempo, implica que há esta possibilidade de posicionar-se, de enfrentar ... as situações de discriminação, injustiça e opressão. Nesse campo, a "luta" é um processo passível de conquistas. É possível aprender, conhecer e ensinar em grupo.

"A criança quando nasce deficiente, ou se torna deficiente depois, como foi o meu caso, passa a ser quase como um bichinho da casa. Era assim que eu era criada. Eu quase não podia fazer nada, e se eu quisesse qualquer coisa, eles me davam. Com isso, a gente não consegue aprender muito as coisas. E nisso eu fui levando, quer dizer, a vida foi passando. E eu percebi que a coisa estava errada quando eu cheguei aos nove anos, pois, apesar de eles me darem o que eu precisava, eu não podia ter opinião própria. Qualquer coisa que eu quisesse, que fosse fora do que eles achavam que era normal, eles barravam.

Eu vim pra cá com nove anos. Foi quando eu percebi realmente que a coisa tava errada, foi quando eu cheguei aqui. Eu cheguei aqui em julho de 69, no meio do ano. Aqui eu percebi que eram diferente as coisas. Se eu quisesse, eu teria que lutar. Pra começar, eu senti dificuldade na escola. Na minha cidade, eu conseguia estudar. Hoje, eu percebo que eu criei uma barreira. De certo modo, foi até difícil eu perceber que era uma barreira. Lá, a gente tem primeiro ano, primeiro ano forte, segundo ano, segundo ano forte, é assim. Você pode estar muito bem, e aí você passa no meio do ano. E eu 
passava no meio do ano. Eu não esperava um ano inteiro para passar de ano. Eu consegui desse jeito fazer a quinta série e aqui eu não consegui mais estudar. Chegando aqui, eu não consegui mais. Mesmo porque eu tinha ainda as pernas muito fracas. Eu comecei a ficar em pé quando eu tinha nove anos, de oito pra nove anos. Eu não agüentava grandes caminhadas. Aqui tudo é longe, em São Paulo, praticamente tudo é longe. A escola, qualquer coisa, que a gente queira, é longe. E lá não, lá onde eu estudava, não. A minha escola era atrás da casa, o grupo escolar. Então, eu saia, eu tinha que entrar às sete horas. Se eu saísse às sete horas em ponto, eu ainda chegava em hora lá. Então, eu não tinha dificuldade quanto a essa parte. Inclusive, eu estava sendo preparada, pela diretora da minha escola, pra ser professora. Ela me dava o maior apoio. $\mathrm{Na}$ sexta-feira, a classe era minha. Era eu que dava aula, porque as professoras achavam que eu ia me sair muito bem. Aqui, na N.E.D., eu também fui professora do grupo, durante um ano mais ou menos. Existia um grupo de alfabetização.

Quando eu saí da escola, eu me senti mal. Não dá pra explicar. Eu não aceitava a situação de não voltar mais a estudar. Todo mundo trabalhando. Meus irmãos, os dois pequenos que iam comigo pra escola, tinham que pegar ônibus pra ir para a escola. Eu não agüentava. Eu não tinha força suficiente pra levantar o pé pra subir no ônibus. Então, eu tive que ficar, e eu não ... eu não aceitava e, com o tempo, eu criei uma barreira, tipo aquela barreira invisível que qualquer deficiente, que não consegue resolver o problema, cria. Não que eu passasse a dizer que a escola não prestava. Mas eu criei uma barreira. Tinha hora que eu queria esquecer a escola e o que eu aprendi. A minha maior dificuldade é que eu não conseguia ler pros outros. $\mathrm{E}$, até hoje, muitas vezes, a pessoa manda eu ler e eu percebo que eu tenho dificuldade de ler.

Com a R..., com os meus problemas, eu, com todas as coisas que eu faço, eu sinto um orgulho muito grande daquele grupo. Eu calculo as pessoas que não têm todas as coisas que eu tenho, o quanto que devem sentir falta. Ontem mesmo, eu estava conversando com o Dito, o Dito sente muita falta. E o pessoal, a Maria, nossa, ela ficou até aérea. A maneira dela era visivel. Ela não se comunicava mais com as pessoas, Foi terrível o que fizeram com a gente. Eu acho que não tem jeito, não aceito, eu não aceito que a irmã Tina tenha desfeito aquele grupo. Aí a gente conhece que é safadeza. Eu mesma, não sei se ela estava mentindo, a gente tinha condições de manter aquilo, só que ela foi muito, muito mesquinha, porque se ela não quisesse tocar mais o grupo, a gente podia tocar. O de transporte, foi ela que destruiu o grupo. Três vezes, ela tentou. Só que, cada vez que ela tentava, o grupo reagia de uma maneira. Então, o grupo conseguia de certo modo abafar. Ela criou um grupo que trabalharia o ano inteiro fazendo promoções, tudo o que a gente podia fazer pra arrecadar dinheiro, para manter a perua que ela tinha que manter. Porque ela recebia dinheiro, ela não vem me dizer que ela não recebia, porque ninguém é mais besta. Porque uma vez ela falou que o grupo, que o nosso grupo, o projeto, umas coisas lá que eu não consegui entender, que tem sempre um fundo de ... ela falou dinheiro. Que o nosso projeto, estava em segundo lugar, só tinha um que estava na frente do projeto. Era um grupo bem maior que o nosso, hoje em dia eu nem lembro mais qual que era o outro grupo. Mas, se o nosso grupo, estava em segundo lugar, o pessoal do governo dava preferência pro nosso grupo. Se estava dando preferência, eu acho impossível que não tinha verba. Eu acho impossível, a menos que ela tenha mentido. A menos que ela falasse: 'não, está em segundo lugar, ou está um último lugar'. Aí, em cima disso, nós criamos um grupo de transporte, que era para ajudar o transporte, que era a coisa que ela mais dizia que não tinha dinheiro. Nós comíamos, a gente ficava o dia inteiro, a gente levava marmita, fazia até vaquinha pra tomar café. Olha, de todo jeito nós apoiamos. Eu tinha uma garrafa, não podia reclamar que não tinha garrafa térmica, eu levei a minha garrafa térmica, pra poder dar o café pra gente. Eu nunca vi uma mulher que chorava tanto. Tinha dia, que ela devia era pedir o café, não o dinheiro, porque eu nunca tinha visto uma mulher que 
chorava tanto. Ela chorava tanto, que tudo que você fosse falar, ela entrava com um papo que não tinha verba."

A inserção em um grupo onde pode reencontrar um antigo desejo, o de aprender e de ensinar, possibilita-lhe sair, mover-se e integrar-se em relações que se pautam por valores de coexistência e apoio mútuo. Em grupo, Nina pode re-significar a condição de deficiente, associar-se para lutar por direitos e, inclusive, lutar para manter o próprio grupo. E mesmo o término concreto das reuniões não pôde apagar a experiência de ter pertencido a um grupo. Essas relações de pertença, de convivência, de filiação, trouxeram-lhe a vivência de situações que permitiram-lhe adquirir e desenvolver características e atributos que hoje aderiram à sua identidade, constituindo-a como sujeito: eu entrevistei Nina, do grupo da N.E.D. de V. I.

\subsection{ALIENAÇÃO: AS DIVERSAS FACES DO FEMININO \\ A História de Tina}

Tina é uma mulher de 34 anos, portadora de seqüelas de poliomielite, apresentando algumas deformidades, principalmente de coluna. Porém, tais deformidades coexistem em um corpo onde curvas, seios e outras formas femininas são habilmente valorizadas por roupas amplas e vistosas, bijuterias e maquiagem. Tem $1,40 \mathrm{~cm}$ de altura e faz uso de muletas axilares e aparelho tutor longo para deambulação.

As entrevistas que realizei com Tina foram colhidas em diferentes lugares. $\mathrm{Na}$ casa dos pais, onde ela morava. No escritório. Em minha casa. Transcorrendo grandes intervalos de tempo entre elas.

Por ser um dos sujeitos com quem mais tive contato, pois, já a conhecia anteriormente, a conversa comigo - ouvinte atenta e submersa na narração -, apresentava-se, por vezes, com um clima de cumplicidade feminina. Era uma oportunidade do encontro de duas mulheres que se reafirmavam como tal, na confidência de pequenos detalhes, pensamentos íntimos e observações sobre as "estranhezas" masculinas. Principalmente, quando o gravador 
não estava ligado. Havia uma conversa de Tina comigo e uma outra fala de Tina, para uma platéia imaginária, representada pelo gravador. Tina dirigia-se ao gravador inúmeras vezes sobretudo quando desejava "esclarecer" frases, que segundo seu julgamento, eram dúbias ou indicativas de atributos que não queria que transparecessem.

O fio narrativo de Tina é a sucessão de seus relacionamentos amorosos, desejados, fantasiados ou efetivados, de qualquer modo, contados com forte colorido emocional. A deficiência, as instituições por que passou e as intervenções de reabilitação que sofreu são pano de fundo dessas "aventuras amorosas". Seu corpo deficiente é cenário das histórias narradas.

Tina inicia sua primeira entrevista remetendo a instalação da sua deficiência a uma época, a um tempo, onde não havia recursos para evitar que contraísse a pólio, nem mesmo para um diagnóstico e tratamento adequado. Sofreu pelo primarismo do conhecimento e foi atendida por profissionais que estavam adquirindo experiência. São os olhos da Tina adulta que se dobram sobre o tempo a olhar o passado. Há coisas que perdeu, há danos objetivos, concretizados nas deformidades corporais, e há outros menos tangiveis, como as experiências de uma criança de menos de um ano no isolamento. É difícil quantificar essas privações e até mesmo, quanto tempo ficou no Hospital, porque "não lhe deram a guia para assinar na saída". Como criança que era, esperava uma certa desconsideração de seus atributos de sujeito.

"Eu nasci em setembro de 56, tive pólio com 3 meses de idade, numa época que não era corrente a vacina, então até detectar que era pólio, furaram meus tímpanos, né, pensaram que eu estava com infeç̧ão de ouvido e aquela coisa toda.

Não sabia disso? É minha filha, me furaram o ouvido duas vezes, para ver o que é que eu tinha, diz que não era nada de ouvido, que a febre era alta, aí que me internaram no Hospital das Clínicas e aí eu fiquei, como fala? Isolamento né? Aí, quando sai das Clínicas que eu já não sei, aliás eu não lembro. Não me deram a data na hora da saída nem a guia para assinar.

Eu lembro que minha mãe conta que quando ela saiu comigo, saiu comigo em cima de um travesseiro, porque a pólio tinha pego todos os músculos do pescoço pra baixo. 
Então, por exemplo, não mexia nada o lado direito, o hemisfério direito do meu corpo não mexia. O lado esquerdo não pegou tanto né, por isso foi mais fácil o desenvolvimento. Em função de um lado ter pego menos pólio que o outro é que eu tive desvio de coluna. Ah! Porque o lado esquerdo se desenvolvia com uma escala e o direito não acompanhava, né, apesar da diferença ser pouca mas isso fez com que a coluna fosse vergando né, então, oi eu..., deixa ver.

Ai foi tratamento normal, assim com médico particular e tudo. Com 6 anos eles resolveram me fazer...detectaram o desvio de coluna com 4 anos. Com 6 eles me mandaram fazer um colete que na época era o Milawkee. Você imagina eu antes de 1960 , o meu foi o primeiro Milawkee a ser feito aqui. Foi antes de 1959 , demorou uns 11 meses para ficar pronto. Era um alemão que fazia, e acontece que quando eu fui me inscrever na CBD o primeiro médico que me atendeu na CBD tirou o colete e mandoume não usar mais. Resultado: se eu tivesse usado o Milawkee até os 12 anos não teria desvio de coluna. Ele tirou, ele me prejudicou, não sei quem é esse infeliz. Deixa ele prá lá, mas eu poderia processá-lo. Eu como profissional, puta merda, eu ia ganhar os tubos, eu pediria uma indenização, já pensou! Não. Vai dar muito trabalho e eu não tenho muita paciência, nem lembro o nome do homem."

Essa idéia implícita de desconsideração por seus sentimentos e desejos e impotência, pode ser apontada em vários outros momentos da fala de Tina, mas, principalmente, quando conta de sua infância.

"Aí, eu entrei na CBD como, como é que fala? Pra fazer....; mas eu já tinha feito o Pré, o Jardim da Infância, perto de casa, lá na M..., e depois quando eu entrei na $\mathrm{CBD}$, que foi em 1960, né então, eles pensavam na unidade, perto da Paulista aonde eu fiz o Pré-Primário e o primeiro ano foi na classe de deficientes, foi o primeiro ano. Ali é uma coisa ambígua de se fazer junto com criança deficiente mental, alfabetizar junto com elas. Eu não era para ser alfabetizada porque eu já sabia ler e escrever com 3 anos. Eu aprendi sozinha, porque também não é nada de excepcional, não sou um gênio. Acontece que a criança tem a sua atenção dirigida para várias coisas que ela pode fazer, por exemplo, uma criança de 6 anos anda de bicicleta, chuta bola, mexe nas panelas, mexe em tudo. Agora, uma criança deficiente com 6 anos, seja menino ou menina, não precisa ser menina para ser esperta, fica mais restrita ao lugar onde lhe põem, vai se voltar para as coisas que pode fazer, vai se desenvolvendo determinados tipos de
facilidades.

Quando eu tive a pólio então como eu não andava, não me mexia e eu não brincava quase. Era um brinquedinho ou outro que punham na cestinha pra mim. Eles me acostumaram, colocaram um rádio para mim, então com onze meses eu já falava feito um papagaio. Eu falava tudo. Quando eu fiz um ano, na minha festa de aniversário quem é que cantou parabéns para mim foi eu mesma. Eu sempre fui muito inteligente (dirigindo-se ao gravador). Quando eu estava com 3, eu gostava muito daquela revistinha do Pato Donald e eles compravam pra mim e eu contava histórias sem saber
ler.

Lá em casa tinha um cesto que nem aqueles cestos de por roupas, antigos. A empregada e a minha mãe, sei lá, me punham dentro do cesto e eu ficava perto dela 
enquanto ela fazia as coisas. Só que eu tinha um rádio, ainda me lembro desse rádio, era um rádio plástico, de uns de uns 30 centímetros, rádio de tomada (porque naquela época não existia esses rádios pequenos) e que me acompanham dentro do cesto. Então eu ligava na tomada e eu cantava: 'melhoral, melhoral é melhor e não faz mal'. Aí eu fui aprendendo a falar. Eu gostava que me pegavam no colo e quando eu não tinha o que fazer ai eu chamava minha mãe, dizendo que eu queria fazer xixi, e era mentira, sempre era mentira e, porque assim ela me pegava no colo, e me levava no vaso, e eu não queria fazer em outro lugar, eu só queria fazer no vaso. Do jeito que era pequenininha tinha que sentar no vaso comigo, sentar e deixar um buraquinho e me por ali do lado. Eu nunca fazia xixi eu sempre fazia pinquinho. Eu dizia, perguntava o horário, tudo para mim era 10:45, tudo era 10:45.

Tem certas habilidades que toda criança tem, mas o potencial vai ser conforme a vida que ela leva. Com 3 anos então eu aprendi a ler, eu lia A Gazeta Esportiva que era o jornal que meu pai comprava. Com 4 anos eu fui pro Jardim que era do lado da minha casa, na M... Era engraçado, minha mãe me levava no Jardim de Infância, só que nessa época eu era tímida, agora não sou, agora eu não sou mais (dirigindo-se ao gravador). Eu me lembro de um dia que eu queria fazer xixi e minha mãe vinha na hora do lanche me trazer o lanche na escola, eu não sei, eu achei que, eu devia estar muito louca, que eu acho que ninguém iria perceber se eu fizesse, eu estava sentadinha na carteira, junto, cada um na sua carteirinha, ninguém ia perceber, então eu fiz xixi e deixei escorrer. Eu estava crente que ninguém ai perceber que era meu. Ai ia complicar teria que pedir pra ela, ter que levar no colo né tudo, eu não tinha esse grau de liberdade pra falar."

Atribui à limitação de atividades um desenvolvimento maior das habilidades mais intelectivas. Essas "habilidades" desenvolvem-se também em função de ter que aprender um certo jeito de pedir. Enunciar simplesmente suas vontades parece não adiantar para tê-las ouvido. É preciso disfarçar seus desejos para realizá-los sempre indiretamente. Pede para fazer xixi quando deseja colo e, quando precisa ser pega no colo, para ir ao banheiro, ilude a vontade e finge não ser ela. Permite-se usar uma necessidade "inquestionável" de ajuda, ligada a suas limitações físicas, como ardil para ter atendidos seus desejos de proximidade e acolhimento. Mas não pode pedir essa ajuda quando esta está verdadeiramente ligada a uma impossibilidade física concreta. Essas satisfações indiretas ou substitutivas de suas necessidades emocionais estão no cotidiano de Tina. No cesto onde ficava tem, por exemplo, a "companhia" de um rádio.

No entanto, algumas vezes esses pedidos de viés não são compreendidos e Tina sente suas vontades desrespeitadas. 
"Aí, tinha a hora do lanche, eu comia meu lanche, depois minha mãe ia me buscar. Aí, eu fiz a inscrição na CBD no começo a gente morava na M. Aí, minha mãe me trazia todo dia para CBD. Como ela demorava muito, a gente ia de ônibus, então não compensava tanto ela vir pra cá, então ela ficava na CBD e depois me esperava na saída da escola pra me levar embora. Ai, ela ficava rodando na avenida. Paulista, pra poder, depois me levar embora.

Era muito engraçado. Eu detestava a escola. Então na hora que eu chegava na escola que meu pai me trazia,... ah! não, foi quando mudamos pra cá, pra V. M. Então ele me levava pra $\mathrm{CBD}$, e eu sempre tinha ataque de falta de ar. Completamente psíquico, não tinha nada a ver, era teatro mesmo. Então eu tinha uma cadeirinha bem na porta, onde eu sentava, eu sentava e tinha falta de ar, porque eu não queria ficar na escola. Eu queria que meu pai me levasse embora, então eu tinha um ataque. Mas elas já tinham a cadeira lá e aí passava o ataque. Ninguém acreditava que eu precisava voltar pra casa. Então eu fui tendo esse trauma desde aquela época. Ai, gente, eu fiquei estudando aqui na CBD e depois me transferiram para a A. R., vocề sabe onde é? Alí na CBD mesmo, ai eu fiz lá até o terceiro ano. Foi uma fase legal, que você tinha mais independência, eu andava, eu comecei a andar aqui na CBD da V. M. E depois lá eu passei a externa. Ia de manhã e voltava à noite. $\mathrm{O}$ que eu detestava era aula de natação, eu tinha horror daquilo. Segunda-feira era um trauma porque o rapaz não tinha muita psicologia. Ele jogava a gente dentro da piscina. Eu tinha um verdadeiro trauma disso. Não pode fazer isso comigo, de jeito nenhum!"

De qualquer modo, Tina pôde, já adulta, retomar as experiências desagradáveis e reelaborá-las. Procura uma escola para aprender a nadar, a "se virar" na água.

"Eu comecei a fazer natação aqui na A., uma escola para deficientes mesmo ou pra algumas pessoas que tenham dificuldades cardíacas. Eu já estava aprendendo, porque o interessante não é nadar, como a Ester Willians, mas sim se virar. Por exemplo, se eu cair de frente na água eu precisava aprender a me virar, então era isso que eu estava fazendo, ai veio a preguiça, e eu deixei a escola. Mas eu pretendo voltar o ano que vem, se Deus quiser."

A entrada na $\mathrm{CBD}$ the traz momentos onde experiencia uma maior independência, ao lado de outros onde a percepção da deficiência é geradora de angústia. Sente-se pertencendo a um grupo de diferentes e este encontro, às vezes, aponta para às diferenças de modo pejorativo. No espaço das crianças não deficientes é subestimada e chamada de aleijada, embora lembre-se de si mesma menos deficiente; era capaz de subir e descer as escadas em curva. 
"Bom, aí eu fui para a CBD e comecei a usar aparelho. Foi, eu acho que aí, a primeira noção que eu tive de diferença, de ver crianças que tinham o mesmo problema que eu, usando tutor ... foi aí que eu vi, que eu me lembro de ver crianças usando aparelho, né. E aí eu comecei a andar com sete anos e aí eu fui estudar na CBD lá no Ibirapuera, né? E eu estudava lá, quer dizer, até os dez anos, então pra mim eu não sentia diferença, sabe?

Então eu fui pra CBD, eu estudei lá na CBD até 1963. Quando eu terminei o terceiro ano o Dr.., (como é o nome dele mesmo?) R. N., ele me dispensou, como é que fala? Deu alta. Teoricamente seria isso. Me liberou da CBD e eu fui estudar no grupo, no grupo escolar mesmo.

Aí, eu era a única que usava aparelho e eu me lembro de uma coisa engraçada; a minha classe era em cima e eu subia escadas, eu subia. A escada era em curvas, os degraus de madeira, me lembro perfeitamente, eu subia e descia a escada com 10 anos. Eu me lembro que, sei lá, que tinha uma professora no meu 4o. ano, que ela pôs os alunos para fazer chamada na lousa, e pra mim ela me dava as respostas, sabe? Ela dava as respostas pra mim, então, quer dizer, aí eu já sentia uma meia diferença, porque com os outros ela não fazia isso e eu sei que comigo ela fazia, eu me lembro disso. Ah! Lembro de um acidente que teve quando eu estava no 40 . ano, tinha aquelas carteiras de madeira e ferro, aqueles pés de ferro imensos e uma daquelas cadeiras caiu em cima do meu pé, né? Então eu não ia pra escola, ficava deitada lá com aquele pé e tudo. Aí o médico foi lá e disse que não era nada. Eu me lembro da cara do médico, disse que não era nada e eu com uma puta de uma dor. Então, eu sempre tive problema com o pé, eu acho que era com o pé. Depois eu saí daquele colégio e fui estudar no colégio de freira, porque a minha idéia aos 12 anos era estudar num colégio interno. Mas não tinha no Colégio que eu escolhi, não tinha internato, então, eu fui estudar normalmente e tal.

Aqui no Colégio, no C. B. Mas na época que eu fui no S. A. eu queria ser interna, eu adorava esta história de Madame Bovary, histórias românticas, de achar que precisava ser internada, sofrer como uma abandonada, eu achava que isso era bonito. Eu queria estudar interna, porque esse negócio de liberdade me apoquenta há muito. I wanna be free! (Dirigindo-se para o gravador.) Na classe, é a primeira vez, eu me lembro, assim de uma coisa que me chocou. Acho que eu tinha 12 anos, uns 11,12 anos, e uma menina me chamou de aleijada. Eu sei que a palavra me fez mal, sabe? Eu me lembro da cara da menina. Acho que era M. o nome dela. Eu me lembro que ela me falou isso, me chamou de aleijada, falou que eu era aleijada, eu sei lá! Eu não sei se foi um xingo, ou se foi só uma expressão, sabe?"

Esse nível de vivência de Tina na escola, parece-lhe não ter espaço para ser acolhida. Julga que suas dores são desconsideradas até mesmo quando concretizadas no corpo. O desejo de eliminar essas experiências desagradáveis do convívio com as pessoas, leva-a a querer o isolamento, mas este ganha o nome de independência. A esse revestimento de desejo de independência é acrescido, mais tarde, o sentido de menosprezo da realidade de suas dores, por ela própria. Não era mais ela e sim uma personagem romântica que "vive" o ocultamento/exibição do sofrimento e do abandono. 
Suas capacidades e limitações não são tomadas pelos outros na sua exata medida. O que realmente sente é desconectado de sua experiência corporal, distanciado e vivido como dramatização, tornando-se explicação "inventada", justificativa "fictícia" para suas vivências.

Essas operações de cisão e deslocamentos levam a uma confusão, indefinição do que é limitação ou capacidade e se estas são advindas da própria condição de um corpo deficiente ou imposição falsa do exterior e, também, qual a natureza e intenção do outro.

Essa obnubilação dos limites da realidade levam Tina ao mundo representado por um duplo registro na memória, há algo que ela sabe e se opõe a uma outra coisa de que se recorda.

A história de seus relacionamentos afetivos é contada com certa nostalgia e distanciamento. Como mulher adulta, tende a olhar o ocorrido como se fora brincadeira de criança, com olhos "condescendentes". Ora esses relacionamentos são fruto, estritamente, de suas "lembranças", ora inconseqüências infantis, ora ainda, iniciados por coincidências explicadas misticamente. De qualquer modo, sempre pairam dúvidas sobre sua real concretude.

"Ah! quando eu estava na CBD a gente brincava muito e tinha um menino lá, ah! coisa de criança, a gente fingia que gostava, tinha um... como é o nome dele? S.? $\mathrm{Ah}$, não lembro! Eu só sei que era um menino que não tinha problema nenhum, só tinha deficiência numa perna só. Eu acho que este menino gostava de mim. Ele me dava um monte de livros, sabe, coisas dele, pessoais. Ainda tenho, lá no sítio, coisas que ele me dava guardadas, assim coisas de crianças. Eu me lembro ainda da carinha dele.

Tinha um outro rapaz que eu achava uma gracinha e tal. Mas eu nunca tive nada com ele. Mas eu me lembro como se eu tivesse, sabe? Como se tivesse aquela movimentação, aquele lance todo. Mas não aconteceu nada, não houve nada, eu só sei

Agora, no meu aniversário de 15 anos, foi na festa um menino que tinha estudado comigo na CBD. Ele tinha pólio também. Não, não era bem pólio, era seqüela de alguma doença aí, algo congênito, porque ele andava depois com 7 anos, ele passada. Mas ele era umdar e tal. Converso com ele, ainda conversei com ele a semana me lembro da deficiência dele aos 10 anos.

$R$. ele chamava, chama ainda. E depois que eu saí da CBD e vim pra cá, a gente continuou. Não, não continuou. A gente não tinha mais amizade. Quando ele ganhou, 
quer dizer, quando os pais dele compraram telefone, eu me lembro que a primeira ligação que ele fez foi pra mim, porque já tinha telefone. A gente conversa até hoje. Cheguei a namorar com ele depois. Foi meu primeiro namorado, o R. Foi o único homem deficiente que eu tive, porque eu cheguei a conclusão que não dá certo, um homem deficiente dá muito trabalho. É dois a dar trabalho. Eu preciso de um homem forte que tenha saúde para me catar no colo (dirigindo-se ao gravador) e, de preferência, que não seja velho, eu já fiz esta experiência, prefiro mais novo, com bastante fogo, né? Porque os velhos vão acabando o gás, não sei. Os novos não, eles têm bastante gás, certo? E para acabar, demoram, pelo menos acaba junto.

Eu me lembro dele, certo? Ele era um menino aparentemente normal. Ele tinha assim uma consistência física normal. Não era, não tinha, assim, uma aparência física diferente, e andava numa cadeira. Mas eu não me lembro da cadeira. Sabe? aí quando eu tinha ... a gente se separou e tal, nunca mais vi. Quando eu estava perto dos 15 anos, ele, o pai dele comprou um telefone, aí ele ligou pra mim, então aí, sabe? começou aquela treta de telefone. Quando eu fiz 15 anos, ele foi na minha festa. Foi assim uma emoção ímpar, sabe? Um negócio, assim, de coração bater, aquela coisa. Tirei até fotografia com ele. Era uma fotografia ridícula que eu já joguei fora, agora. Mas tirei fotografia com ele. Ele tinha uma ameaça de bigode já, sabe? Uma coisa assim e olhos azuis lindíssimos. E bom, ai a gente ficou naquele negócio de conversa por telefone, conversa por telefone ..., e ai, de repente, a gente começou a namorar. Eu tinha 16 anos, ele estava para fazer 17. E nós namoramos um ano e pouco. Só que, eu tenho, estou te contando dele porque eu não assumi o corpo dele. Não assumia a deficiência dele, o que, na época, quando eu comecei a namorar, a seqüela dele estava muito mais forte, muito mais marcante. Ele tem, ele é muito magrinho, ele tem os membros muito fininhos. Ele é uma pessoa bastante debilitada, e já naquela época com 16 anos ele era assim. Eu me lembro que a gente foi viajar, eu fui com ele. Nós fomos pra Santos e nós estávamos no pátio do meu prédio e uma menina que era amiga minha, que a gente se encontrava sempre nas férias, chegou pra mim e falou: 'Oi como é que está e tal. E aí? Está namorando?' E ele estava do meu lado e eu disse que não. Eu disse que não. Eu não assumi na cara dos outros, quer dizer, sabe? Com as pessoas mais íntimas, tudo bem, sabiam que eu estava namorando e tal, né? Mas as outras pessoas, eu não, eu simplesmente, pra mim, ele não existia. Foi então que eu senti que eu não tinha, eu não sei o que é. Se não é a minha aceitação ou se eu não aceito nos outros. Eu acho que eu não aceito em mim também. Nos outros, é porque eu vejo, em mim, eu finjo, faço de conta que eu não estou vendo."

Afinal, onde está a deficiência? Nas lembranças de Tina, a deficiência não é uma condição estável. Há situações em que esta ganha relevância e salta em primeiro plano, geralmente, a partir da constatação da deficiência instalada no corpo de outrem.

Percebe-se deficiente quando vê outras crianças usando aparelho tutor. Pode refletir sobre a aceitação do próprio corpo quando defrontada a assumir publicamente que está interessada por alguém também deficiente. Há outras ocasiões em que é preciso e possivel relativizar ou mesmo negar tal condição em si e no outro. Principalmente, quando o interesse afetivo suplanta a valoração negativa que atribui à deficiência. E quando não há a intervenção 
de um terceiro observador que poderia trair, denunciar a estratégia de encobrimento.

A assunção de preconceito com relação à deficiência, por parte de Tina, tem um quê de confissão, de culpa. Viveu com ambiguidade a relação com R. Desejava-o, mas este não constituía a figura idealizada de homem mais velho e "menos" deficiente, representada por Alceu. O desejo de abandoná-lo é acompanhado de culpa e gera fantasias de castigo e autopunição. Vive coincidentemente uma situação concreta, mobilizadora de angústia: a cirurgia de coluna. O desejo e o medo de morrer mesclam-se, já num primeiro momento de distorção da realidade de seus sentimentos, e the servirão de "falsa" justificativa, racionalizada para o desejo e o medo da separação de R.

Tina tem lembranças conflitantes e simultâneas do real, baseadas em percepções antagônicas. Há uma percepção mais adulta, que pode reconhecer um risco real de morte, e mecanismos infantis, que garantem a função apaziguadora da mentira. Há, ainda, uma operação de afastamento e exacerbação, dramatização desse risco que reforça a confusão entre realidade e fantasia. Estes mecanismos possibilitam também a percepção dessa realidade, de uma forma que possa adequar-se mais a seu desejo de transformar uma argolinha em signo/selo de um noivado.

"Então, assim, ficou né? E eu desmanchei com ele e tal e fiquei só na paquera e tal, de outros. Eu desmanchei com ele. Foi muito engraçado. Eu bancava muito a boazinha, altruísta, né? Eu ia fazer uma operação aos 17 anos. Eu resolvi fazer uma operação da coluna né? E esse menino namorava comigo nessa época, mas eu estava de olho em outro, percebe? Eu estava de olho em outro mais velho. O outro também tinha pólio, mas muito pouquinho. Ele tinha deficiência só no pé. E não foi por isso que me simpatizei com ele. Foi por, sei lá, ele me dava atenção, ele era amigo do meu primo, a gente saía juntos, assim, enormemente. Então, eu peguei e comecei interessar pelo A. Quando eu comecei a me interessar por ele, eu joguei o outro meio pra escanteio. Eu não dava bola pra ele. Eu fingia que ele não existia e ele foi ficando puto, né? Aí, eu resolvi que ia desmanchar com ele. Mas, uma desculpa, assim, pra todo mundo: que eu tinha medo, que eu morria e ele ia ficar sofrendo. Tudo mentira, né? Eu resolvi desmanchar com ele exatamente porque eu estava interessada em outro. Quanta tragédia, Nossa Senhora!

Eu fui no médico e eu queria que ele me garantisse que eu não ia morrer. Ele falou que eu não ia morrer. Tudo mentira mesmo, porque eu podia ter morrido mesmo. Qualquer um pode morrer numa sala de cirurgia. Mas eu fui mais confiante. Eu achei que eu não ia morrer mesmo. Quando eu estava no hospital, eu estava na CBD 
internada, esse rapaz foi me visitar. Ah! Foi um Ah! Sabe? Todo mundo falou porque todo mundo viu o rapaz, sozinho, indo me visitar. Foi aquele negócio. Mas nessa época brinco. Eu tinh uma argolinha portugu que a gente pegava, sabe? essas argolinhas de um negocinho reto aro enfiar. Era eu enfiei no dedo de parecia um anelzinho. Então hospital que dedo da mão direita e andava como noiva. Eu dizia para todo mundo no irmão de uma una fotografia, não sei porque cargas d'água, do eu achava que eu tinha, que

Pelo trabalho da memória, Tina liga e re-significa acontecimentos que ganham um caráter mágico, ao ponto, por exemplo, de ela passar da trama romântica ao conto de fadas. O surgimento de um homem, príncipe encantado, saído do vídeo da TV, é explicado misticamente, trata-se de uma relação cármica pertencente a outro plano de realidade. Esse acontecimento tem grande importância para Tina, naquele momento, porque pôde fazer com que suportasse, quase como vivência parạlela, o período de internação hospitalar.

"Ai. Bom, saindo do hospital, eu continuava meio apaixonada pelo A., mas durante o negócio do hospital aconteceu uma coisa engraçada, eu conheci um outro
cara, no hospital mesmo ...

Em 1970 tinha um reclame na televisão sobre o Volkswagem, e tinha um rapaz que chegava num Fusca, assim, e dizia que ia buscar a titia no aeroporto. Ele largava relógio, ele dizia que ia na casa da outra e, pra todas, na hora que ele olhava para o lindo, sabe? Um tinha que ir buscar a titia no aeroporto. E e era um menino muito internada e um dia eu estava Assim, eu babei a primeira vez que eu vi. $E$ eu estava rapaz. Falei: 'Nossa que cara lindo!' Tinha uma uma televisão no quarto), e eu vi esse mim e falou assim: 'Esse é meu sobrinho, vou te apre no meu quarto e ela virou pra emoção, fiquei emocionada, acontece que foi ... Sai da CBD. Fui para o hospital, fiquei Nisso, minha mãe pegou, foi abrir a porta da operação, bateram na porta do quarto. $1,90 \mathrm{~cm}$ de altura, com uma camisa pret Quando ela abriu a porta tinha um rapaz de jeans). Um puta de um homem lindíssimo. Minha mãe falou assim: ' época já usava se enganou de quarto'. 'Não, a Tina não está aqui?' Minha mãe falou: 'Está'. 'Então é que eu me apaixonei. Apaixonei-me nova ainda meio grogue da anestesia. Eu só sei era o cara do reclame. Ele tinha ido CBD, ele não sabia onde eu estava, então hospital para me ver. Eu não estava mais na meu médico que ele era meu primo o médico então deu todas as infico e disse para o estava, quarto, tudo. Ele bateu lá no hospital. Bom, só sei que ele ia me visitar, assim, conversando, assistindo televisão, e muito carinhoso comigo. E eu, de mãos dadas. Era assim, algo que ... mexia comigo minha cabeça. Vinha um, vinha 
sumiu e eu tenho, assim, de vez em quando, muito raramente, notícias dele.

Mas foi um cara, assim, que foi muito importante pra mim naquela época. Eu me sentia muito sozinha, né, e um homem bonito daquele te indo ver sabe, indo te ver. As enfermeiras ficavam, assim, pra lá e pra cá, porque era uma beleza, assim, estonteante, sabe? Muito lindo, muito lindo. Então depois que eu sai do hospital vi umas ... logo em seguida eu vi, ele foi umas vezes em casa, depois começou a espaçar. A vida vai mudando."

O relacionamento com este rapaz inscreve-se a uma distância da realidade de Tina que, quase como um devaneio, efeito da anestesia, vai-se sem explicações, da mesma forma que veio. Já a proximidade com A. é maior, ele é mais familiar, pertence ao círculo de relacionamentos de seu primo. Dessa forma, simultaneamente, exige e presta-se mais a uma atuação do desejo. Contudo, todas as tentativas de concretização por parte de Tina levam-na à frustração e separação. Estas experiências de confronto entre suas fantasias e a realidade são tão radicais que a aproximam do desejo de morte.

O outro sim, me deu problema, o tal que tinha um pouqinho de paralisia, né? Eu resolvi que eu tinha que me declarar, certo? Que aquele negócio já estava me enchendo o saco, ficava naquele, teretetê, teretetê, teretetê e não acontecia nada. Então eu tomei a iniciativa e fui e pumba né? Escrevi uma puta de uma carta pra ele, eu não me lembro mais do que eu tinha escrito na bendita da carta. Ah! tem um lance de uma outra carta que eu preciso te contar também.

E, essa carta, eu sei que eu escrevi pra ele porque a coisa era assim: ele era amigo íntimo do meu primo. Estudavam sempre juntos e ele tinha mais dois irmãos mais novos, né? Mas todos eles, o único que era mais novo que eu, era um mês mais novo que eu, e isto era tudo, uns três anos mais velho. Então a gente saía muito junto antes, né? Eu saía com os quatro, depois que eu esperei eles forem viajar comigo para o sítio, eles iam passar o fim de semana, os quatro, comigo. Esse que eu gostava, ele tava fazendo vestibular para medicina, então ele me ajudava ... ajudava minha mãe fazer curativo na minha perna, sabe? Então eu comecei a me empolgar muito por esse cara. Depois que eu tirei o gesso tudo, né?, que eu tava andando já, já tinha voltado para a escola, eu resolvi dar um xeque-mate nele e escrevi uma carta pra ele. Dizia que eu estava apaixonada, e o resto eu não me lembro. Eu só sei que ele sumiu, sabe? E eu não sei se coincidiu com isso, eu tive um problema: eu fui pra psicóloga, né? Porque eu tinha medo de morrer, eu não dormia de noite, sabe? Deve ter alguma relação, porque a minha terapeuta ainda não chegou a esse ponto porque eu parei. Porque estava ficando muito caro. Eu parei de ir na terapia, mas ela disse que tinha alguma coisa a ver. Mas ela não sabia ainda o que era, né? Porque, eu fazendo escândalo, sabe? Até que eu fui na médica, numa psicóloga, né? Indicada pelo meu ortopedista lá mesmo, né? Ele fez mil testes pra mim e tal, sabe? E um dia ela me perguntou se eu nunca tinha querido me matar. Nunca mais eu voltei nela. Nunca mais. Eu tava lá com medo de morrer, a filha da puta vai me perguntar se eu queria me matar! Eu não sei se tem alguma coisa a ver, só sei que os grilos pararam. Parou. Acabou, entendeu? Parou, eu deixei de ir na 
terapia, né? E voltei a aparente normalidade, né? E eu tinha 19 anos nessa época. Aí eu fiquei, depois desse cara, desse ... que ele nunca mais apareceu, eu fiquei vários anos sem ninguém, né? Quando eu entrei na faculdade, um dia me ... de toda boa vontade né? Isso liguei pra ele. Liguei pra ele, falei pra ele que a gente precisava levar um lero, fui preparada prae? Fazia uns quatro anos que a gente não se via, não liguei. Bom, eu estava bolado na minhar com ele, ja tava tudo bolado na minha cabeça, entendeu? já gente foi num lugar onde quando o meu ... cara chegou, já esta o gerente. Ela era amiga do gerente. Então sair, ficar papeando com o gerente, e eu ficambinado dela ir conversar com o gerente, eu ia embora com ele, e ela ia ficar. Eu iar conversando com ele. Se desse tudo certo, Tu com o cara, sabe Deus para onde, né? Mas voltou a falar de proble conversou numa boa, né? A gente antes, né? E nunca mais assim, quer dizer, a gente lavou a roupa, que estava suja perguntar, alguma coisa do meu vai o cara sabe? Ele me telefonou uma vez para me pra fábrica e pergunta, né?' E não Pô, eu falei: 'Você está me ligando só pra isso, liga puta comigo né?' Eu falei: 'Tô, mas acabou'. Ele há uns falou assim: 'Pô, você ainda tá sítio, deixou um bilhetinho lá. 'mas acabou'. Ele há uns dois anos atrás teve no meu escritório pra ele, de onde eu tô funcional com saudades e tal'. Mandei um cartão do procura. Se não precisar, acabou. Esse acabou."

A impossibilidade de efetivar a cena idealizada move Tina a buscar satisfações substitutivas. Tece uma outra trama da mesma história e desta vez, procura Roberto para contracenar.

"O outro, o R. que eu deixei, que eu joguei lá atrás, por causa do A., né?, antes da operação que eu ia morrer, então eu larguei o. R. Ah! teve um dia que eu tava, e eu acho que eu tava realmente numa necessidade física, né?, e eu não tinha perspectiva de homem nenhum. Então o que eu fiz, liguei para o R. e ele sentiu que o troço tava meio pra cá e tal, aí a genteç, então ele disse: 'Olha, daqui a uma meia hora eu tô aí. E veio pra cá e tal, aí a gente teve a maior treta né? Só não dormimos juntos, só isso, mas tudo
que é possível, a gente armou e tal, aparentemente, a gente voltou a namorar. Mas só eu não gostava mais dele. Eu senti se eu podia engravidar. Ele disse que sim. Então aí eu fui ao médico, perguntei pra ele 'Bem!, se eu tiver que casar, eu já sei que posso ter filhos'. Nisso preparada, disse assim: lá. Aí a gente ficou um mês mais ou me posso ter filhos'. Nisso eu tinha 21 ou 23, sei não sabia. Ninguém tinha falado tal. E de repente a gente resolveu que simplesmente, né?, tinha dado uma transadinha $\mathrm{e}$ dois, sentia mais nada um pelo outro."

Embora não tenha havido uma coincidência total com o planejado, é possivel duvidar se engravidou. Mas Tina conta a provável história implícita na sua atuação, ou seja, a 
moça que precisa casar porque engravidou, de forma invertida: "Se eu tiver que casar, eu já sei que posso ter filhos".

A história tecida por Tina, o caminho de seu desejo será reapresentado, reatualizado, com outros personagens repetidas vezes, no intuito de experimentar-se mulher.

"Então eu fiquei sem ninguém durante um bom período. Até que eu me apaixonei novamente. Eu acho que, hoje, eu acho que não foi bem paixão. Eu queria ocupar o meu tempo, a minha cabeça, e tinha um cara na faculdade que era muito tímido e tal e o modo dele tratar, de me tratar, me levou a crer que tinha alguma coisa a
mais ..."

No relacionamento com seu corpo de mulher deficiente, o humor e a imersão da situação, transformadas em seu oposto são outros mecanismos que Tina lança mão para relativizar as situações de dor e sofrimento.

"Essa fase, foi um ano de .. Ah! foi nessa fase que eu fiquei na CBD. Fiquei acho que uns 15 ou 20 dias na CBD fazendo natação, e é horrível, sabe?, porque você se sente psicologicamente mais para baixo que o cu de cobra. Então, você não tem como ... Porque eu nunca tinha ficado, nem internada sozinha, Ah!, sem estar com alguém de casa. Então, eu era sozinha mesmo, e não foi legal. Aí, de lá eu saí, fui direto para o S. Fiz a cirurgia. Depois, do S. voltei pra CBD. Eu fiz 15 dias de tração, né? Na cama amarrada ao leito, esse é bom, né? Você já imaginou que cena de curra que dava isso? Ah! Como é que é aquele filme que a mulher prendeu um cara na cama, acho é Misery não vi, eu me lembro que alguém currou, Ah!, mas que maravilha poder fazer um troço desse. Então mas aí fiquei 15 dias nessa ... Você fica muito pra baixo pra ter essas idéias. Olha, pra baixo eu gosto, eu não gosto é pra cima. Nada de experiências, exóticas, eu era tão cruazinha, era tão ingenuazinha eu, e meu Deus! Achava que sabia de tudo. Continuo achando que sei de tudo. Não sei de nada. Mas eu fíquei lá 15 dias. Depois saí fui pro S. Foi engraçado, tem uma passagem muito cômica nessa época, porque eles engessavam você desde o pescoço até o quadril, né? Só que, depois da tração, antes da cirurgia, e eu fiquei três dias lá feito um frango no espeto me secando ao sol, pra o gesso secar. Que o gesso secava. Aí, eles abriam uma janela redonda, aqui na barriga, pra você poder respirar com mais facilidade porque o gesso te oprime o peito, pulmão, barriga, tudo. Foi aí que eu fiquei com esse ovo estrelado que é o meu peito hoje em dia, que logo logo vai sair se Deus quiser, né? Então eu saí da CBD, que ele me deixou passar um final de semana em casa, antes da cirurgia, e eu fui pra casa. Só que na época aconteceu um acidente com a família, nós perdemos uma tia, e meu pai, e meu pai e minha mãe, tava aquele alvoroço, porque ela tinha morrido dentro de um hotel, fora de São Paulo, aquela loucura. Eles foram para a casa da filha dessa tia, né? E eu fiquei com a empregada em casa, e o Doutor O. ligou pra minha casa e falou: 'Que é que você ta fazendo aí, que não vem pra cá?' Tỉnha que estar no hospital. Mas eu falei: 'não posso ir para o hospital, não tenho quem me leve, ele falou assim: 'Então 
aguarde (como se eu fosse sair, né?), que eu vou te mandar uma ambulância. E ele me com a serra na mão. E a ambulância me casa. Ele queria operar mesmo. Ele queria, tava S. e o enfermeiro, que tava me acompanhando, tireto para o hospital, pro S., e eu fui pro no saguão, deserto. Olha, imagina, coberta até me deixou, assim, encostada, na maca, pra disfarçar um pouco o gesso. Deitata né? largo, é grande. Então chegou uma dençol, e o gesso é distribuem santinho dentro do hospital. E ela velhinhas, sabe aquelas velhas que assim: 'Filha, tenha calma, né? porque vai ela encostou do meu lado na maca e falou Quer dizer, a velha achou que eu ia ter un dar tudo certo, né? Esse é o seu primeiro?' então coberta, né?, ela não percebeu que neném, porque eu tava engessada inteira e gesso e falei: 'Minha senhora, isso aqui é gesso'. barriga não era minha, daí eu bati no se ria, né?. Isso foi muito cômico, porque a mulher a mulher não sabia se chorava ou Imagina, ela me achou tão jovem, ela falou a mulher achou que eu ia ter um neném. primeiro, foi cômico. Essa fase eu me lembro" " você é tão jovem, ainda, mas é o seu

Aí

junho de 1971 , a primeira vez dias. Eu tinha 17 anos, foi, oh! eu operei no dia 1o. de né?, eles separavam, antigamente era uma carnifimpo operatório e fez todo o preparo né?, da coluna. Demorou umas horas carnificina, né? Eles deslocavam os músculos, preparado para o implante ósseo, né? Pra poder fazer, pra deixar o campo operatório que quando voltei pro quarto não podia ficar fazer a segunda cirurgia. Eu me lembro mudar de novo, então ficavam me virando ficar na mesma posição porque não podia ficava quatro horas em cada posição, né? Era um frango no espeto, sabe? Não podia, aí, depois, no dia 12 de junho, eu fui operada pela segunda dor, uma dor terrível. Então, o que eu ainda tenho na coluna que é uma haste em segunda vez. Foi quando ele colocou, nas minhas costas, é invertido, e com uma haste em Tinvertido, eu tenho um baita tesão né?, tem o enxerto lá ainda."

Tina fala jocosamente das intervenções médicas em seu corpo. Percebe que há uma total desconsideração pelas repercussões emocionais que tais atos podem gerar, o que contribui para aumentar esse hiato entre seu corpo e seus afetos. Há uma negação de suas dores e de sua fragilidade e, também, de seu corpo como espaço da feminilidade. As cirurgias "corretivas" visam a conformação de um corpo, instrumento funcional, retirando-lhe as formas e funções femininas. No entanto, sente-se capaz de recuperá-las, pelo menos, parcialmente, através de cirurgias estéticas que ela decide fazer ou, mesmo, através dos "enganos" dos outros, que imaginam que, sob o volume do gesso, está grávida."

"Mas então o que mais, então eu saí do hospital fiquei 11 meses engessada né? Foi uma época assim onde tive a imobilidade né? Meu pai mandou fazer uma maca pra morava na casa, exatamente onde eu tequinininha, para facilitar né? Então, e a gente nos mudamos para uma outra casa, aqui perto, na V.rório hoje né? Foi nessa época que 
a maca, meu pai botava dentro da Kombi, eu viajava com eles para o sítio. Quer dizer. eu não fiquei presa na cama né? Até que o Dr. O. me deixou sentar, pra ... que eu podia viajar sentada então aí era cômico porque a gente fica tão comprimida né? engessada. Porque ... e eu me sentia um verdadeiro poste, né?, completamente oscilante. Batia um vento e eu oscilava, mas, eu fiquei 11 meses assim. Ah! ele não tem, acho que o Dr. $O$. não tem miolos, né? na cabeça, porque no dia, veja só, ele me mandou internar em maio do ano seguinte, né? pra tirar o gesso. Eu fui pra $C B D$ ele pega me vem, me raspa o gesso com aquela serra. Vrummmmmmm, sabe? Que ele fez? Me fez pôr o aparelho e me pôs de pé, depois de onze meses em decúbito dorsal, o homem me pôs de pé. E a sorte é que ele tava lá, porque o mundo inteiro rodou, rodou, rodou, verdade. A minha gana era botar sutiã, como eu queria botar um sutiã naquela época, Nossa Senhora!"

O problema do gesso era o seguinte, o doutor $O$. ele cometeu um crime comigo. Ele me engessou com o seio achatado, ele não fez (como depois eu vi em outras cirurgias) que o gesso fazia o contorno do busto. Pra mim não, ele engessou por cima. Então estralou meu peito. Aliás com 1,40 eu uso, a botinha Dos peitos é 46 'bico largo'. Então é peito pra mais de metro né? E eu quero fazer uma cirurgia plástica aqui, vamos ver. a M. fez né? E não caiu. Dá pra pensar, porque o meu, quando eu fui fazer. Você sabe que eu fiz de barriga né? Ah!, sim minha filha, porque também esse lance, né? Quando você usa colete, então eu ficava meio apertada aqui em cima e fazia uma espécie de dobra na minha barriga e assava. E então eu peguei fui no médico e falei pra ele que eu queria fazer plástica de barriga e busto, aí ele olhou, olhou e falou assim eu faço uma, escolha. E eu escolhi fazer a barriga porque era o que me incomodava mais sabe! Até pra transar, porque eu ficava com vergonha da minha barriga, eu juro que eu tinha vergonha da minha barriga, porque era uma espécie de sainha. $E$ eu fiz lipoaspiração, achei legal pra burro né? E agora eu tô a fim de fazer busto, mas eu quero ver se consigo fazer com convênio, quero ver se eles fazem em função do desvio de coluna, se eles fazem a cirurgia. Então, mas aí, o doutor O., então, me fez essa sacanagem né? Que me fez ficar com esse busto estrelado.

A gente tem que ser vaidosa entendeu? Tem que ser. Na hora que começar a cair as coisas, eu vou começar a pôr tudo pra cima de novo. Lógico que, esperança, já que tem essas diferenças, então eu acho um ponto fundamental sabe? Por exemplo, eu queria fazer uma análise. Mas hoje talvez não dê para falar tão claramente. Mas você vê, a gente já tem um problema de auto-aceitação, né? Você não se acha bonita, você não se acha gostosa, não se acha interessante, não se acha nada né? Então você acha que o outro sempre tem mais que você né? E de repente você percebe que não, porque o que importa é o prazer que o teu corpo te dá, entendeu? Então se é bonito ou feio isso não altera, não altera nada, eu cheguei a ter muita vergonha. Hoje eu não tenho mais não. Não tenho não, eu digo pra todo mundo, que eu penso muito melhor pelada. Penso, eu penso, eu acho que é psicológico isso. Olha, como direi pra você no começo foi difícil, mas com o primeiro, primeiro, porque com o primeiro segundo não, não foi. Porque agora você já tem a ... você já se conhece, entendeu? Você não tem mais vergonha, eu não tenho mais vergonha. Não sei se acontece a mesma coisa com você, com o primeiro você tá assim ó, toda né? Não me toque, por favor, não me olhe, né? Aí depois, não, você tira de letra. Porque você não sabe a reação que o outro vai ter, né? Eu tive oito anos de uma experiência muito positiva. Sabe? Eu nunca gostei de homem muito bonito, porque eu sempre acho que não é comigo a coisa, entendeu? Não é comigo né? E sempre acho que é muita areia pro meu caminhãozinho. Não é isso, não é."

Acho que é fundamental a gente aprender a se gostar, a curtir sabe? Por exemplo, esse lance de liberdade, está sendo importante em todos os níveis pra mim. $O$ fato de eu pegar, sem o motorista, pegar o carrinho (porque 15 dias que o motorista tá 
de férias, né?) e pegar o meu carro. Eu amarro minha muleta com um extensor de bicicleta. Eu prendo ela no meu triciclo, e depois, eu me vou, vou embora, né? Então, lá, eu pego, abro a minha porta, entro, fecho a porta, tiro a muleta e tudo, quer dizer, é uma coisa muito importante, né? Eu vou nas lojinhas, toda a vizinhança me conhece."

Tina sente-se capaz, em certo nivel, de opor-se às experiências de dor e reelaborá-las a partir da busca do prazer. Remodelar seus seios, poder ficar nua consigo mesma, principalmente apoiada em vivências de prazer obtidas através da aceitação de si pelo outro, contrabalançadas pelas experiências de autonomia e liberdade. Não se trata de uma convicção inabalável, como, às vezes, deseja transmitir. Mas parece poder crer que seja possivel o encontro com esse corpo real, espaço misto da dor e do gozo, e conseqüentemente, reencontrar-se e ser reconhecida pela vizinhança e pelo mundo.

O relacionamento com as outras pessoas, principalmente no espaço do trabalho, também guarda outros aspectos "menos confortáveis".

No discurso de Tina, suas preocupações profissionais, seus relacionamentos com os clientes, outros colegas de trabalho e suas dúvidas quanto à aptidão para a advocacia, ocupam grande espaço.

"Eu estava falando do relacionamento com meus clientes. Você nunca tem certeza que o cara te fala a verdade, este pelo menos.

Esse é um sacaninha que não paga pensão. O cara é um cara muito esperto, muito vivo e eu sempre tenho o medo de estar sendo ludibriada. Òs vezes ele fala assim: 'Não Doutora, mas é que eu ...' Ele faz questão de me pagar adiantado. Isto me deixa, está me deixando com a pulga atrás da orelha. Ninguém me paga adiantado. Eu fiz um contrato de honorários com ele. Tinha que me pagar $50 \%$ no início, $25 \%$ no meio, $25 \%$
no final.

Ele já me pagou o início, o meio e hoje vai me pagar o tinal. Só que ainda eu não tenho resultado nenhum. Mas ele disse assim: 'Não Doutora, eu sei discernir uma profissional. Eu sei da sua preocupação com o meu caso, e a senhora está me dando uma assistência perfeita.'

Eu não sei se o cara está gozando da minha cara, ou se ele está realmente confiando em mim. Isso é um papo de insegurança. Não sei se é isso que me leva a dividir meu tempo entre a advocacia e as crianças. Eu estou dando aula de novo. É, estou dando aula de novo. Eu tenho alunas da faixa de 10 anos de idade, 9 anos, 10 anos, 12 anos. Assim eu me sinto mais segura. Porque eu sei que eles não estão me sacacaneando. Eu acho que isso é minha grande falha profissional. Eu não percebo, as 
coisas passam pelo meu nariz e eu não vejo se o cara está sendo sacana comigo ou se não está."

Tina fala de sua insegurança no relacionamento com os clientes porque acredita que possam ter segundas intenções que não consegue apreender.

No caso narrado, parece haver uma identificação com a esposa a quem o cliente está devendo, surgindo dai uma idéia de estar sendo "subornada" pelo pagamento adiantado e pelos elogios. Há uma questão ética não explicitada. A defesa de alguém que não merece confiança gera dúvidas sobre a moral do defensor.

Na verdade, essa desconfiança é gerada em um processo de projeção e reintrojeção onde pairam dúvidas sobre as intenções do outro e sobre as suas próprias capacidades, inclusive a de suspeitar. Contudo, é justamente quando o cliente the paga adiantado, contradizendo suas expectativas, talvez de não receber os honorários, que Tina teme ser ludibriada. Estranhamente, a suspeita surge quando recebe o que the é devido.

Esse medo é diminuído quando Tina dá aulas para crianças. Atribui às crianças uma atitude mais sincera, verdadeira, isto é, não dissimulada, em oposição ao "comportamento adulto" onde impera a malícia. Tina parece ter dificuldades em lidar com dois pólos que estabelecem: a malandragem e a malícia e a pureza, ingenuidade.

Anseia por saber mover-se nesse mundo adulto. Transpor a aparência infantil, perder a confiança no outro. Adquirir malícia, exatamente para ganhar a confiança do outro e ser tratada na mesma altura. Existe uma ligação implícita entre seu tamanho, aparência de "criança", com a deficiência e, possivelmente, a conseqüente desvalorização profissional. No entanto, Tina prefere deslocar isso para um campo estético: felizmente não parece velha!

"É uma falta de malícia, o B. diz que com o tempo eu vou perder isso. Mas, quando, meu Deus? Isso me deixa às vezes meio angustiada. Òs vezes eu relaciono a falta de confiança profissional que as pessoas possam ter (isso pode ser transa da minha cabeça; às vezes, eu fico preocupada com isso), com a cara que eu tenho (que, graças a Deus, não é de velha) (dirigindo-se ao gravador) e o tamanho que eu tenho. Então, às vezes, eu fico pensando ... assim, será que as pessoas estão me levando à sério? Estou melhorando isso, eu estou tendo mais confiança em mim. Mas, ao mesmo tempo, eu 
sinto falta de lidar com crianças. Então estou dividindo meu tempo com estas coisas. Não é fácil, mas é uma coisa que me agrada pra caramba, lidar com crianças. Eu tenho um aluno que é minha paixão. Ele agora está de férias. Mas, ele, na hora que sai, depois que ele sai da aula, ele me abraça e me beija. Ele tem 9 anos de idade, é uma gracinha, o tipo de filho que eu queria ter. Ele é lourinho com o cabelo não muito claro, loiro, castanho claro. Ele também tem os olhos castanhos claros. Então ele é um boneco, magrinho, pequenininho. Ele é uma gracinha. Superinteligente, faz redação com orações coordenadas. Sabe fazer sentenças compostas por coordenação. É o maior barato, ele põe conjunções entre as orações. Ele só tem 9 anos. Está um ano adiantado, está na quarta série, normalmente a 4a. série é com 10 anos. Ele vai fazer 10 em novembro, quando tiver terminado as aulas. Então, eu divido o tempo. Òs vezes me dá uma bruta insegurança de não saber se é isso, se é advocacia que é o meu, se é a criança.

Ao mesmo tempo que faço esse tipo de trabalho. Não sei se te falei que estou fazendo com o B. um outro trabalho com adoção. Eu estou bastante inclinada a entrar nesse campo. Ele largou a área toda que estava trabalhando só para lidar com adoção. Se bem que ele ainda tem muitos clientes de criminal, porque ele é sempre nomeado advogado dativo, que é aquele advogado que não ganha do cliente.

O Juiz nomeia e depois o Estado paga aquela porcentagem que você sabe que é uma merda. Mas ele ainda tem. Ele não larga cliente. Ele não larga os caras na rua da amargura. Mas estar lidando com criança é uma coisa que me apaixona demais. Isto está mexendo muito comigo, sabe? Está mexendo muito e esse tempo todo você não acredita como eu fico."

Estar trabalhando com crianças, além de desempenhar esse papel de reasseguramento da sua condição de adulta, ainda a remete a uma relação com a função da maternidade, dentro de um trabalho tradicionalmente feminino: ser professora. Essa menção à maternidade, a uma certa forma de ser mulher, faz com que Tina comece a me contar sobre sua relação com Bernardo, um homem mais velho, também advogado, com quem mantém relacionamento já há alguns anos. Fala da sua posição neste relacionamento, como aquela que anseia pelo outro e busca essa conquista pelas armas da sedução, através da demonstração de aspectos frágeis e de dependência, tornando-se literalmente doce e submissa.

"Sabe o que eu fiz? Tomei banho de açúcar. Você já ouviu falar? É uma transa assim que você fica doce. Diz-se a palavra ... que quer dizer 'o que é chamado, que chama'. Então, quando está muita gente em sua volta, a gente fala que tomou banho de açúcar! Eu fiz isto na segunda-feira. Mas não deu em nada. Minha filha, me produzi toda, combinando calcinha, sutiã e tal. Me depilei, me depilei, não, me raspei, que ele detesta que eu faça depilação. Mas acontece que não deu tempo de eu fazer depilação, então fiz na gilete. E não aconteceu nada. Estou tão chateada." 
Na verdade, a submissão ou não às vontades dele é dúbia. Aliás, como tudo que Tina the fala, são meias-verdades e meias-mentiras. Tina transforma as suas necessidades reais e as puras manifestações dos sentimentos em pretensas estratégias de sedução.

"Na segunda-feira eu estava puta, de noite. Mas eu também pensei, tem que levar em conta que ele estava doente, com uma gripe do caramba e estava sem carro. Estava passando mal. Na terça-feira, ele já estava melhorzinho e a gente tinha combinado de ir para o sítio dele essa semana. Ele me convidou. Eu falei com ele. Eu te contei o lance que eu joguei tudo em cima dele? Falei pra ele que tinha um outro cara, 'Não, mais ou mo com um outro cara e ele falou: 'Pô, você transou com ele?' E eu falei: assim: 'Você mostrou para disse: 'Como é que a gente trepa mais ou menos?' Ele falou é uma mentirosa'. Na verdade é uu falei: 'Não'. Ele falou: 'Então como é que foi? Você teria coragem. Se bem que o cara muta de uma mentira. Eu inventei um cara. Eu não com esse cara. Ele é um cara casado, então eu bocado, mas eu inventei que eu transei mesmo porque eu descobri que ele era casado.' Mas ele achou que era mentira. pra ele, pra falar com tao, emocionalmente, ... meia insegura que quando eu liguei associado a verdade porque eu estava chorando."

A mentira sobre o encontro com um outro homem desejado e não inventado como Tina quer fazer crer em um primeiro momento, é a explicitação distorcida e indireta de seus anseios de ser amada. Tina chora com medo de ser abandonada mas insinua que suas lágrimas foram simplesmente um estratagema de convencimento. Crê que B. "acreditou" na medida em que, talvez, tenha compreendido o sentido que Tina escamoteia.

"Aí eu falei um monte de coisas, que eu não conseguia esquecer dele. Falei que para mim era a melhor coisa que estava acontecendo do ano passado pra esse. Joguei queria discutir esse assunto. 'Por isso que 'Aí você vai voltar com esse assunto?' Eu não não queria mesmo sair. Eu ficava imaginando que a gente motel. Quatro horas juntos, mas três horas ia que a gente ia ficar umas quatro horas no legal, então, eu perdi o ânimo.' Então eu disse: 'Se o problema é esse, meu amor, na coisa, não toquei mais isso, porque aquilo. Eu não assunto de a gente não se ver com mais freqüência, porque com ele."

Essa primeira atitude de acolhimento desencadeia em Tina a declaração direta de 
seus desejos de tê-lo sempre e muito. Ante a percepção dessa operação de usar os sentimentos como meio de conquista, de maneira intensa e sôfrega, Bernardo reage afastando-a. A aparência escancarada com que Tina fala de suas pretensas "vontades" serve para distanciá-la dela mesma e do outro. Tina interpreta a reação de Bernardo como um pedido para calar-se.

O silêncio. Tina também o apresenta como estratégico. Parece-lhe que na ausência de seu desejo pode ocorrer a iniciativa do outro, que lhe fala cenograficamente de amor.

"Na outra vez que eu liguei, ele virou para mim e falou assim que estava a fim de me levar pro sítio dele. A gente ia de tarde ficava lá até de noite, acendia a lareira. Ele começou a explicar: acendia os lampiões, apagava a luz elétrica, a gente ficava na frente da lareira, quer dizer, ele deu o maior tesão. Depois ele falou do mesmo jeito: 'Não, a gente nem precisa ir de tarde, a gente pode ir de manhã e a gente almoça junto e fica lá até de noite.' Bom, então eu me produzi toda porque eu não ia na casa dele fazia duas semanas. Na semana passada eu liguei para ele. Falei assim: 'Olha, dia doze, terçafeira, é dia de lua cheia e eu quero ir lá na lua cheia. Acontece que não tinha aparecido esse programa domingo com o casal para adoção. Então, como não tinha aparecido ainda, a gente estava, assim pensando em termos que a gente iria transar de novo, né? Mas apareceu esse negócio. Embora a gente não ligue que não vai transar, a gente está mais preocupado com o lado profissional. Quando a gente estava voltando da casa do cliente, que eu ia levar ele para casa dele, ele virou e disse: 'Olha que lua! Uma lua que estava ..., o motorista estava no carro, mas mesmo assim ele falou. Eu disse: 'Pôxa né?, não vai dar pra gente ir né?? 'Não, eu não sei ainda se vai dar, vamos ver. O carro, vou tirar da mecânica quinta-feira.' Mas eu falei: 'Pô, quinta-feira o meu irmão vai embora, vai viajar. Além de tudo, eu não vou poder. Não disse que eu não ia poder. Mas, aí, terça-feira, não, quarta-feira, ele falou que o carro só ia sair hoje. E hoje eu sei que ele tem problema, que ele teve que ir lá no sítio, junto com um cliente. Então, quer dizer eu não liguei para ele nem ontem, nem hoje. Não falei com ele, eu não sei como vai ser.

Mas eu tive que ... eu tô maluca. Tô maluca, maluca. Eu tenho estado assim. Eu olho para ele, toda vez eu tenho que me segurar. Me segurar para não subir no pescoço dele. Aí, ele na segunda-feira, na frente do casal, na hora em que ele ia embora, ele me abraçou, me deu mil beijinhos na testa (quer dizer, um horror, mas porque estava gripado). Na hora que eu fui abrir a porta do escritório para ele, o casal já estava lá. Eu abri a porta, ele nem viu o casal, ele meteu a mão na campanhia, 'bem', 'bem', 'bem'. Eu fui abrir, ele disse: 'Ah, você não abre essa porra dessa porta?' brincando comigo. Quando eu abri a porta ele me beijou dos dois lados do rosto e falou:- Não é bem aí que eu queria beijar mas eu estou com uma gripe danada'. E foi entrando. E eu pedi para ele falar baixo que o casal estava lá, mas todo mundo já tinha ouvido. Depois, ele ficou me abraçando e beijando. Aí que vontade de pegar ele!"

Na sua relação com o trabalho Tina irá exprimir suas formas diferentes de viver e ver-se mulher. Não há uma separação entre os caminhos por onde expressa-se e busca a 
satisfação afetiva e aqueles por onde pretende realizar-se profissionalmente.

Para Tina é a "mistura" da relação afetiva e profissional que gera expectativas, "faz fluir", "mexe com ela". Mas há pelo menos duas áreas de trabalho que Tina distingue e sobre as quais mantém-se dividida quanto à qual melhor se adequaria a ela.

Há o trabalho de dar aulas para crianças, que se realiza no espaço doméstico e de onde retira recursos financeiros moderados, porém com regularidade. É um espaço onde os acontecimentos parecem-lhe mais previsiveis e estáveis, e onde as relações que estabelece são mais diretas e isentas de subterfúgios. O papel de professora/mãe substituta possibilita que Tina represente-se enquanto mulher em um papel mais tradicional e menos ameaçador.

Já o trabalho como advogada, como profissional liberal, é exercido no espaço público e exige "malícia" e o convívio com a criminalidade e a violência, aspectos identificados como mais pertinentes ao mundo adulto e masculino.

"Então a gente estava misturando o lado profissional com o lado afetivo e lógico que daí vai sair coisa. Agora eu não sei quando. Isso está mexendo comigo. Eu estou com uma série de coisas no escritório também. Dá a impressão de que a coisa está começando a fluir, que está começando haver um desejo de conhecer, tem coisa que eu não conhecia quando comecei no escritório. A gente ficava meses sem receber clientes. Agora não, tem uma porção de clientes. Mas, vamos ver. Eu não tenho aquela estrutura ainda pra dizer: 'Esse mês eu posso comprar isso, aquilo, aquilo outro que eu sei que o dinheiro vai entrar'. Isso me põe muito nervosa. Então eu tenho umas aulas também que me dão um fixo, bem ou mal sempre é alguma coisa. Eu não gosto de pedir dinheiro em casa. Odeio, odeio. Não fiz a terapia porque não estava a fim de pedir para o meu pai pagar para mim. Depois de muitos anos, já com uma estrutura você pode dar assessoria a empresas e eles te dão um fixo. Mas ai fica aquele negócio. Eu sou a única advogada aqui no escritório. O Paulo e a Cláudia são estudantes ainda. E, na minha insegurança, o Bernardo fica puto, eu dei participação pros dois. Ele ficou puto da vida. 'Vocế tá louca, você não pode achar que você tem necessidade dessas pessoas.' Mas, ao mesmo tempo, eu me sinto assim insegura de, de repente, ter que ir até o cu do Judas. O P. mete o carro na rua e vai. Ele não tem o número da $\mathrm{OAB}$, não tem porra nenhuma. Mas ele indo, ele se vira e pega o que é preciso. E como também eu não podia dar um salário ... Mas, também, pro $P$. não interessa salário porque ele é rico. Então eu dando uma parte de participação no escritório pra ele, ficava bom. Mas eu falei: 'Acho que eu estou amarrada com esse homem pro resto da vida.' Mas sou eu que assino, sou responsável por tudo. Eu não sei se é insegurança, eu não sei o que é. Você entendeu? Sei lá, fica uma situação estranha! Eu gosto muito deles. O P., não sei, tenho um negócio assim com ele, porque ele mexe muito com cara de delegacia e eu tenho a impressão que não dá para a gente dividir, porque ele faz o trabalho lá, (porque o combinado era tudo que viesse nós colocaríamos no escritório). Mas esse negócio de delegacia se resolve sem justiça, sem ser necessário assinatura, então só fica no papo e na grana. Então eu não vou me meter em delegacia. Ao mesmo tempo que eu acho que ele podia trazer para o 
escritório, eu acho que ele está certo, porque eu já falei que eu não vou me meter em qelegacia. Não vou ficar para cima para baixo armada (porque ele anda armado, quer que todo mundo ande armado), ir até a delegacia ou tomar pinga na esquina com os
caras.

Ele quer fazer a parte criminal. Precisa ser homem, ser macho. Não necessariamente homem do sexo masculino. Precisa ser macho, precisa ter estrutura interna. Não precisa ser macho, precisa ser uma pessoa de malícia, coisa que eu não tenho. Então eu fico naquela bruta dúvida se eu devia fazer penal ou não deveria fazer penal. Será que penal vai trazer grana ou não vai?"

Neste espaço Tina coloca-se como se tivesse menos condições de mover-se sozinha e, também, há uma recusa ativa em aproximar-se desses aspectos mais recrimináveis das pessoas.

Ante a imprevisibilidade da violência e de seus próprios desejos sexuais e agressivos, Tina afasta-se dessa realidade carnal, falando de aptidões paranormais de previsão. Misticamente é possivel saber de mortes e perdas, e de estados de gravidez. Ainda assim, não é possível controlar, segundo seus desejos, essas previsões.

"E uma outra coisa que eu nunca comentei, não sei se você acredita em paranormalidade, essas coisas. Também não é questão de acreditar porque também, às vezes nunca viu acontecer. Eu estava freqüentando um terreiro de Umbanda. Eu comecei a ficar meia assim ... eu parei de ir lá, aí eu comecei a ir numa senhora. Não pago nenhum tostão lá, nada. E ela ora e quando ela ora, ela é vidente. Não sei se você por semana. mediunidade. Eu ia lor eu ia lá no centro, a mulher disse que eu tinha uma lado espiritual'. Porque eu ,u precisava aprender uma coisa assim: 'investir no meu nessa, ela viu uma luz uma auro espiritualidade. A outra disse a mesma coisa. Eu fui grande e receptível e é uma coisa que grande em volta de mim. E essa aura é muito coisa, de repente, começo. Acontece me dá medo. Não é que eu vejo coisa. Eu falo 'Deixa eu ver, vou comprar 10 números' sabe que você vai ganhar? Eumeros'. E eu comprei 10 números. Sabe quando você móveis. Estava lá no escritório, estava no escritório que a gente estava mudando os aquele quadro, que vou ganhar na rifa na sala de visita e falei: 'Cláudia, vou colocar falei. Na sexta-feira, que eu chegueif, e vou colocar ele aqui.' Uma coisa assim que eu tinha ganho. Então são coisas que, às vezes, minha mãe falou que eu tirei, que eu tenho que aprender a lidar com isso, porque, acontecem. Aí, essa irmã disse que eu quando faltavam dois dias, era 13so, porque, às vezes, não vêm coisas boas. Lembra Eu sei que me deu um troço. No de março, dois dias antes do Tancredo tomar posse? que o cara não vai tomar posse, ele vai mo manhã eu falei para minha mãe: 'Eu acho está doida menina vira essa boca pra lá'. Dorrer'. A minha mãe ficou ..., ela falou: 'Você no vídeo. Minha mãe veio e falou: 'O . De noite eu estava tranqüila assistindo um filme aquilo me deu um troço? Ò toa, me vem 
minha avó morreu. Quatro dias antes, eu senti isso. Mas eu liguei pra lá, minha avó passando bem. Foi numa segunda-feira. Na quinta-feira minha avó foi internada de manhã. Foi operada na hora do almoço e morreu à noite. Um mês depois eu senti a mesma coisa: foi com o primo do meu pai. E aí deu uma folga, deu uma folga para minha cabeça. Agora, de vez em quando me acontece. Uma coisa assim engraçada que aconteceu com o colega meu, de faculdade, com o A. Nós estávamos um dia para sair, pra tomar um troço, sei lá, e ele levou a irmã dele que era casada. O marido dela estava viajando e ela estava na casa dele e ele levou ela junto para passear. Então ele me apresentou a moça e no dia seguinte eu falei: 'A., sua irmã está grávida?'. Não, que eu saiba, por que?' 'Porque eu acho que ela está.' Mas ela não tinha barriga, não tinha nada. Aí um dia, o A. disse: 'que boca você tem, minha irmã foi fazer um teste de gravidez e ela está grávida!' O A. vive comigo, diz que eu tenho que calar a boca. No meu último ano de faculdade tive uma amiga minha chamada N. A N. saiu, foi viajar com o namorado. Foi pra Angra. Quando ela voltou, um dia eu virei pra ela e disse assim: $N$. você não está grávida?' Ela ficou tão puta comigo: 'Vira a boca pra lá, você está louca.' A mesma coisa. Faltava alguns dias pra vir, ela nunca imaginava que estava grávida e estava. Sabe? então, quando é gravidez eu acho lindo, mas predizer morte não é uma coisa muito boa assim, é tão, é assim. São coisas tão bestas. Essa história do quadro do palhaço, de uma outra história de uma manta, uma manta de crochê feita a mão. Eu falei: 'Vou ganhar aquela manta'. No bingo, mas todo mundo fala: 'Vou ganhar aquilo e isso'. Mas quando eu falo, eu ganho. É estranho. Mas não é sempre que acontece. Por exemplo, eu jogo na loto e nunca veio na cabeça que eu ia ganhar. Mas quando eu falo que eu vou, eu faço. Eu sei lá se isso é positivismo da mente, que droga que é! Mas às vezes me dá medo. Eu sabia que o Tancredo não ia tomar posse. Ficou aquele chovenão-molha, chove-não-molha, mas desde o primeiro dia eu sabia que ele não ia. Agora você pergunta: como?! O homem fez uma operação que era não sei o quê. Nunca senti, quando eles falavam que ele ia tomar posse, nunca senti. Quando ele entrou para o hospital confirmou minha primeira previsão. Nunca, nunca achei que eles estavam falando a verdade. Então você entendeu? E é umas coisas assim que eu sei lá. Òs vezes, é minha intuição, às vezes, é uma coisa que você pode usar, mas usar de uma forma ... pra melhorar. Eu não sei se você acredita nisso, nessas coisas, o que você acha disso? Me disseram que eu era sensitiva. Tem médium que diz que você não nasce assim, que é uma coisa que você não nasce com, você, desde pequeno, tem época da vida que começa aumentar. Então vai indo, vai indo ... Por exemplo, quando eu estava na faculdade eu escrevia poesia, escrevia muito, mas sabe, é uma coisa que eu estava conversando com você e, de repende, eu pegava o papel e ia assim direto. Eu tenho um amigo que tem todas as minhas coisas desde essa época e ele disse assim pra mim: que minhas poesias não eram naturais. Ele é espírita e disse que o que eu escrevo é paranormal. Sabe? é uma coisa que me fascina, mas que é uma coisa que me dá medo também. Eu gostaria de saber lidar com a coisa entendeu? Se Deus dá uma coisa, deveria dar também saber como usar, como deve usar. Então eu não sabia. Se desse uma coisa ruim, o que eu deveria fazer? Agora eu já sei eu tenho que me concentrar e rezar. Rezando você consegue manipular a coisa, não totalmente, mas você consegue

Transpostas para esse nível de explicação mística, suas dúvidas profissionais e até mesmo a relação com Bernardo ganham outro significado. Trata-se de saber quais ações estariam coerentes ou não com a tendência do destino, a fim de que ela não fizesse nada antinatural, contra os ditames de uma ordem exterior, divina, que lhe escapa. No entanto, a 
realidade do caminho já trilhado, a limitação do tempo, expressas na sua idade e anos gastos em sua formação, apontam-lhe que já realizou escolhas, já assumiu papéis e que há restrições nos caminhos possiveis de serem trilhados.

"E essa irmã, D., ela vê muita coisa. O primeiro dia que eu fui lá, eu tive uma crise de nervos na hora, que eu só conseguia chorar lá com a mulher. Depois eu me senti muito mais calma, eu estou mais tranqüila e tudo. E ela me disse se ele (Bernardo) tivesse que voltar, ele voltava. Como é que apareceu esse caso, dessa criança, que eu não sabia como lidar? Sexta-feira? Pra eu puxar ele? Não sei, mas acho que tem muita coisa além do que a gente entende. Então se eu puder usar isso dentro do meu serviço, tipo visualizar o que eu posso fazer de melhor, não sei. Tem a minha coisa com criança, que isso também não é uma coisa ... Eu me sinto muito bem quando eu estou com criança, não importa a idade, bebê, não importa, pra mim é uma coisa engraçada. Acho que até com você acontece um pouco isso. A semana passada foi dia 24 numa segundafeira, a minha empregada, a fillha dela teve um bebê, e ela já tem uma filha de três anos e, na terça-feira, como a moça estava na maternidade, a minha empregada trouxe a menina de três anos (a menina é um capeta), pra avó ver o nenê. Menina!. Olha Rita, ela não queria sair do meu colo. Tem aparelho, tudo, que machuca. Não é uma coisa suave, é uma coisa dura, machuca. Nem com o pai dela. Ela fez questão que eu visse o nenê, ela só falava comigo, ela não queria que ninguém falasse na distância do bebê, só ela podia falar sabe?. Aí que eu fui sair da maternidade, aí eu fui pra o escritório que já era tarde, aí eu fui ficar no escritório. $\mathrm{E}$ eu me transformo, sento no chão brinco, brincamos adoidado eu e ela, aqui me senti tão bem. Acho que eu não sei se eu vou ter vocação. Lidar com gente grande é tão ruim. Eu não sei, não sei. Sabe, de vez em quando vêm as dúvidas. Mas ao mesmo tempo, eu já tenho 31 e meio, quase 32 e tenho uma formação profissional que não tem nada a ver com criança. Só que eu, sei lá, não vou levar por esse lado né? Vou trabalhar cada vez mais. É uma coisa estranha, muito
estranha."

Há também que considerar que o trabalho como advogada the possibilita uma aproximação cotidiana com Bernardo, o qual aparece-lhe como modelo, mestre a conduzi-la pelos corredores e trâmites dos tribunais. Nesta relação com características "filiais", experiencia uma condição de mulher, frágil, dependente e insegura, mas desejante.

"Mas profissionalmente ele tem me ajudado um bocado. Que apesar de a gente não ganhar nada com júri, eu tenho feito júri com ele. Eu sinto lá uma insegurança enorme porque eu tenho vergonha de falar. Ele me joga batata quente na mão no meio do negócio. Eu sei que eu tenho as argumentações, mas eu me sinto, eu sinto sempre como se os argumentos do outro fossem os verdadeiros, sabe? Eu acho que tenho que ficar sempre na, dentro do direito, e na verdade não é bem assim. Eu posso fazer uns charmes, uns dramas e mesmo que seu cliente não tenha todo esse direito você inventa 
certo? Então você cria uma fantasia.

Conforme for, agora no dia 19 de setembro se eu não estiver viajando, vou ter um júri de aborto. Vou fazer sozinha, quero fazer, eu quero. Já falei pra ele que eu quero que ele desista pra eu fazer sozinha e ele falou que não vai nem assistir, se não eu vou ficar olhando na cara dele e vou pedir apoio, e ele não quer isso. Quer que eu faça sozinha. Mas eu quero ele lá, você entendeu? Dá um puta medo, é um cagaço miserável, mas eu gosto, é uma coisa que me chama muito sabe?. Você pegar detalhes, eu gosto muito do serviço de investigação, o que vai pra júri são só crimes, homicídios, tentativa de homicídio. Então, um matou o outro, ou pelo menos tentou matar né? Então, ai, você precisa realmente gostar, porque você tem que ver os depoimentos de todo mundo, tal. E é uma coisa que, vamos dizer assim, processualmente falando, a seqüência, o como construir a casa, eu sei que eu não tenho base. Sabe? porque eu não fiz área de penal e eu gazeteava diversas aulas de processo penal sabe? Gazetear dá a impressão que eu sou velha. Não é gazetear. Eu cabulava (dirige-se ao gravador), então, eu sei que eu, pra isso eu acho que não estou preparada. Eu me sinto mais forte no papel, escrevendo, eu consigo colocar todas as palavras no lugar certo e ninguém vai me apartear, porque eu gosto de encher o saco do promotor na hora que ele vai falar, falar, falar duas horas. 'Vossa Excelência' me dá um aparte? Então, você tem que aprender a cortar o barato do outro né? Fazer ele perder a linha de raciocínio, isso o Bernardo tem de montão sabe?. Ele faz tudo, me pega, me tira do bolso um helicopterozinho de plástico (não tinha nem $5 \mathrm{~cm}$ o helicóptero), começou a brincar de helicóptero em cima da mesa. Aí foi falar para o jurado do helicóptero, que tinha sido uma criança que tinha dado pra ele. Não tem nada o cu a ver com o helicóptero, mas desvia a atenção. Ele ganha os caras no carinho, sabe. É uma malícia que eu não tenho ainda. Preciso ter. Ando planejando, pra esse júri de aborto, inventar uma história, inventar que eu também fiz, que é uma mentira, mas, sabe, porque eu acho que não existe uma pessoa nesse Brasil que não tenha feito, né? Então, todo mundo sabe de alguém que fez. Não acho justo alguém ser condenado porque fez um aborto. Não acho nem um pouco justo. Então, não sei, espero que eles não queiram me prender porque eu confessei um aborto né? Mas eu não decidi, eu só joguei essa idéia pra ele e ele arregalou os olhos, mas não sei como eu vou fazer ainda mas eu quero fazer.

O B. vive no escritório, como advogado é superexperiente, apesar de ele ter se formado há pouco tempo. Um ano a mais do que eu só. Antes ele não era advogado. Ele trabalhava com graxa. Subgerente de uma fábrica de graxa para usinas. Ele conheceu Itaipu, lá debaixo do rio. E ele já fez de tudo na vida, até caminhoneiro. E meu caminhoneiro. Mais é a profissão como advogado, acho que ele nasceu pra ser advogado. Ele tem pique, principalmente, criminalista. Eu não sei se eu nasci pra ser advogada, sinceramente eu não sei, mas eu gosto."

No júri também há uma permissão, concessão à teatralidade, objetivando convencer, passar como verdadeira uma das possíveis interpretações da realidade dos fatos, advindo daí aspectos que agradam a Tina. A malícia e sedução deixam de representar elementos exclusivamente negativos e passam a ser instrumental de trabalho.

O trabalho com adoção de menores, tal qual o realizado como advogada dativa, não visa diretamente uma realização profissional ou financeira, busca mais satisfações indiretas 
de necessidades de outra ordem. É um meio caminho entre as experiências com as crianças e como advogada, solução de compromisso entre a mulher, mãe/amante, à medida que atende simultaneamente ao desejo de "estar" com crianças e próxima de B.

"Essas pastas são todas de casos de gente do consulado. Eu recebo assim, três vezes, telefones interurbanos por dia. Essa semana não teve nenhum. estou até estranhando. Mas, tenho muitos amigos, muitos mesmo né? A C., esteve um casal aqui, eles vieram aqui no escritório, ela estava aqui, apresentei: 'Esta é minha sócia, ela fala francês?' Não conseguiu falar uma palavra. O menino que eles adotaram vivia pedindo que arranjassem alguém, que amasse, alguém pra ele. Olha não é fácil. Eu soube de um, aquelas coisas que eu estava te falando, o promotor teve que arrombar a casa. $O$ pai ficava com ele e bebia. Batia nas crianças e amarrava dentro de casa e ficava, dois, três dias, as crianças sem nada pra comer. Os vizinhos não suportaram mais e chamaram, e foram lá com força policial pegaram as crianças. Estavam assim numa situação deplorável. Aí, chamou os pais e os pais desistiram das crianças. Então é assim. Porque eu acho não é ser pai, transar e fazer o filho e depois? Não é nem durante a gestação, é muito bonito. Me invoca muito esse pessoal que bota a criança no mundo. Deixou transar e depois? Mas eles casam, até acontece isso, sabe, mas, é aquela história. Manja, cachorrinho novo? Tudo quanto é cachorrinho novo é lindinho, mesmo vira-lata. É uma gracinha quando bebezinho. Espera crescer e dar trabalho. Por isso, que tem muita criança grandinha. Bem, que no último orfanato, que a gente foi, que estava o último garoto. Eu fiquei apaixonada por um negrinho, ele não me largava. Nós fomos levar o A. pra se despedir dos amigos né? Foi a assistente social. Um casal junto. Queria conhecer aonde ele tinha morado, foi junto né? E ele foi se despedir dos amigos. Foi lindo, mil fotografias. Mas ele sai de uma realidade muito triste, porque, ai é que tá: tem todo o lance social, a pessoa pra adotar que tem condição sabe? Uma pessoa que não tem condição de ter uma criança simplesmente não tem autorização governamental para adotar. Mesmo aqui, pra você adotar um filho, você precisa. Não é como você botar no mundo entendeu? Não é como você trepar. Ninguém vai perguntar se você ganha um salário mínino ou dez milhões por mês, né? Mas pra adotar você tem que ter um mínimo de condições. Agora, por exemplo, esse casal que vem pra adotar quatro. Significa isso, que eles têm uma situação muito privilegiada, extremamente privilegiada. Eles têm inclusive contatos políticos. Ele é secretário de um dos ministros do governo. Agora, não sei, como nós, nem um Juiz que vem e, entre nós, não sabia que existia quatro crianças. E através do Juizado de Menores daqui de São Paulo que nós falamos: 'Olha tem uma cidade aqui perto?' Ela deu o nome do Juiz, deu tudo. Tem as fichas com as fotos das crianças e nós passamos a informação pro Consulado. Liguei, então recebi três telefonemas. Foi feito uma triagem pra ver qual casal tinha condição. Pra você ter uma idéia, eles moram numa casa de campo. Ele tem uma indústria, ela é pedagoga, já têm professores especializados na escola, que vai assessorar no aprendizado da língua estrangeira. No controle de cada um deles. Fica com um canto pra cada um, ou seja, cada um vai ter seu quarto. Você imagina alguém que tem disponibilidade numa casa, vai ter um quarto da maneira que quiser. Eles não ganham o que a gente ganha. O nível de vida que as pessoas têm é outro. Então, puta, isso gratifica enormemente sabe? Você no aeroporto, você vê a menina solta a mão do pai e vem te beijar pela última vez e dizer 'aurevoir'. Não tem o que paga isso. A gente só ganha quando tem que continuar o processo né? Porque ele continua. Quando continua, eles não voltam pra cá. Se o processo dura um ano, a gente cobra só as custas. Porque também não dá, o que dá é aquela puta satisfação de você 
ter amigo para o resto da vida. E eu não ganho nada com isso. Veja bem, a gente faz contato, faz reserva em hotel. Eles pagam todas as despesas. Tanto se a gente for pra lá, tem lugar pra ficar, tem amigos."

Quando Tina fala de preocupações estritamente de trabalho e de finanças, menciona desde providências pequenas, próximas e concretas como a reforma do escritório e instalação de uma placa até planos mais distantes como a intermediação de negócios com o Exterior.

"Mas ninguém recompensa o profissional com o que ele merece. Tem gente que me liga falando de problemas pessoais, sabe? Eu vou pra casa pra almoçar, sabe. Depois eu saio daqui 9 e 10 horas da noite. As pessoas ligam pra falar dos problemas: 'olha o meu vizinho me deu um tapa, sabe?'. Eu não sei como é que acontece isso, mas acontece. Mas você está construindo uma coisa mais objetiva, forte, sólida. A gente está se preparando pra montar um escritório legal. Por exemplo, ontem eu acertei a última coisa que estava faltando, que é a placa. Uma placa imensa do lado de cá, quase $200 \mathrm{~m}$ né? Essa placa vai me abrir um campo, porque eu quero ser conhecida pelo logotipo. É um logotipo novo, quero que o bairro, que a região conheça. Porque quero que isso me ajude a começar corretagem de imóveis. Estou me preparando pra tirar o CRECI. Aí, sim, eu vou ter condição. Por enquanto estou emprestando de um colega né? Então, aí, a gente vai ter condição de poder passar por outra etapa. Olha você tem que ter um corretor. Uma carteira de clientes. Imóveis pra serem vendidos. Eu tenho muita locação aqui. E é o que me deixa louca, muita locação, mas que me dá trabalho. Dia 10 é uma desgraça nesse escritório o tempo inteiro. Mas área de compra e venda a gente fez muito pouco ainda. Assim, compra e venda de um imóvel de 3 milhões. Você, a porcentagem que a corretagem leva é $6 \%$. O que seria normalmente, as empresas de imobiliária de compra e venda, elas dão $40 \%$ pro corretor e ficam com $60 \%$. Nós vamos oferecer $50 \%$ por $50 \%$, porque nós não estamos ainda com uma carteira de cliente, vamos ter que sair à rua, ir a campo. Então nós queremos ter aqui um corretor. Aliás, vou colocar anúncio no jornal. Alguém que esteja a fim de abrir um campo né? E o que nós, como advogados, fariamos é, quando já estiver pra fazer negócio, seria o que eles chamam na gíria de corretagem, de fechamento, que ai acerta os últimos detalhes e prepara o contrato.

Agora, quero fazer contato com Portugal e montar um escritório associado Portugal-Brasil, porque Portugal é a porta da Europa no Mercado Comum, quem quiser se estabelecer tem que ser agora. Nesses próximos dois anos. Tava tudo engatilhado, porque tinha uma empresa daqui que quer montar um negócio lá, é que são maus clientes.

A viagem minha à França seria a passeio, agora, Portugal seria mais pra contato profissional. Eu faço clínica geral aqui, faço tudo, área trabalhista, área comercial. A gente tem que diversificar. Antigamente era diferente, mas hoje o mercado é mais fechado." 
A história de Tina, mulher-adulta, criança-deficiente, advogada, professora, amante, comporta histórias diversas, com diversas versões e reedições, permitindo-nos encontrar personagens femininas que, contracenando, expõem fragmentos das possiveis formas de se viver a condição de mulher. Tina é única somente na capacidade de colocar-se e (re)encontrar-se nas diferentes mulheres que habitam seu mundo. 
Oh! Mae, me explica, me ensina, me diz o que é feminina. Nốo é no cabelo, no jeito, no olhar, é ser menina por todo lugar. Oh! mãe, então me ilumina, me diz como é que termina.

Termina na hora de recomeçar, dobra uma esquina no mesmo lugar ...

Joyce 


\section{4 \\ EXPRESSÕES DA DEFICIÊNCLA}

\subsection{A INSCRIÇÃO NO RITMO DA VIDA: TEMPO, MOVIMENTO E DESEJO}

Ao ritmo próprio da narrativa de cada sujeito corresponde uma forma peculiar de organização perceptual da passagem do tempo. Essa percepção temporal é a base, a matriz onde se dá o registro do suceder da vida e tem íntima relação, senão for o campo mesmo, no qual se constitui a identidade individual. A história de vida é contada a partir da (re)-atualização e (re)-interpretação do passado pelo trabalho da memória. Este trabalho tem um ritmo, ou seja, expressa-se em tempos que guardam relação entre si e na costura de espaços objetivos e fantasiados. No vértice, formado pela junção desses espaços, representados pela realidade e pela matriz do desejo, respectivamente, temos o processo de formação e transformação da identidade ao longo do tempo.

O reflexo deste processo, de construção e reconstrução deste sentido de imanência, pode ser percebido por uma matriz individual que também organiza a direção e o ritmo da temporalidade.

O peso da vivência do tempo pode ser mais facilmente considerado na história de Márcio, justamente pela sua dificuldade de se inserir em seu fluxo. No seu discurso, é flagrante uma certa "confusão", uma indefinição no uso dos tempos verbais. Tudo acontece "de 
repente", o tempo se mostra por "flashes" exatamente porque a percepção do passado-presentefuturo, como um suceder contínuo, depende do estabelecimento de relações çausais, depende, também, da percepção de intencionalidade, que articula, põe em relação a percepção de si e da ação. Estes aspectos não surgem explicitamente em sua fala. Há ações destituídas de sujeito e há tempos desprovidos da sucessão que lhes é inerente.

Da mesma forma, os movimentos mencionados são sem sentido, sem direção, sem alvos claros. Parece não haver contato com a superfície da realidade, não há atritos. Tratase de um movimento retilíneo e uniforme. Ele ocorre e se mantém por inércia, embora pareça haver uma força motriz interna que o inicie. Porém, não há tampouco nenhuma "explicação", nem uma percepção muito clara de que esse movimento seja iniciado por ele. O movimento tem uma origem que the parece exterior, alheia. No mínimo, há um descompasso, uma ruptura entre desejo e ação, rompimento, entre sujeito, ação e objeto.

Como, para realizar, mesmo que parcialmente, o desejo é preciso lidar com o tempo, projetar-se, dirigir-se para um alvo distante no espaço e no tempo, o seu desejo, o seu querer é colocado na "carona", no movimento de um outro que não ele mesmo. Para se realizar tem que coincidir com o caminho alheio. Para realizar conecção entre desejo e uma possível satisfação é preciso que este desejo seja sobreposto a um movimento que se realize por ação de um outro sujeito. Dessa forma, não pode colocar o outro como objeto alvo, de desejo, não pode desejar o outro. O outro não é causa ou objeto de desejo, mas é oportunidade de levar seu desejo por ele. Não pode dirigir seu desejo e fixá-lo num alvo exterior. Não pode colocar-se como ser desejante. Logo, diante dessa impossibilidade primeira, não pode "escolher" esse ałvo, não pode colocar-se, seja como homem, seja como mulher.

As razões dessas impossibilidades e das possíveis crenças que as sustentam são dificeis de perscrutar num estudo como este, mas, talvez tenham ligação com as éxperiências extremas de frustração que Márcio experimentou ou em função da limitação de escolhas e de autonomia experimentada pela submissão às rotinas institucionais nas entidades por que passou.

Por outro lado, em Robson, há uma preocupação em manter a flexibilidade de ir 
e vir no tempo, em mover-se autonomamente na sua história. Nos momentos de crise conseguiu segurar as pontas do passado e do futuro garantindo que não houvesse uma ruptura, uma desagregação, ainda que em alguns períodos tenha tido que colocar a deficiência como elemento exterior e distante de sua pessoa. Mesmo essa operação de defesa está inserida em um trabalho de reencontrar as expectativas de futuro, que tinha no passado, agora, no presente, para, inclusive, construir o futuro ... desse presente. É preciso reencontrar as formas de realização do desejo do passado e retomá-las no agora, com as exigências de alteração que a condição do hoje impõe. É preciso retomar o final da adolescência e revivê-la como adulto.

A percepção da vulnerabilidade do corpo e dos limites do tempo contribui para o amadurecimento, altera as expectativas da adolescência mas não as suprimem.

Há um refazer do desenho do desejo sobre a matriz original. Há "pedaços" desse desenho que terão que ser completados ou refeitos dentro dos limites de uma gestalt préexistente.

Edna, por sua vez, vive uma suspensão na sua história, um tempo vazio de memória, uma parada, representada por um lapso de memória. A partir dessa "suspensão do tempo" tenta voltar ao ponto exato e da forma exata, quando ocorreu a ruptura.

Nega, desconsidera, a passagem do tempo e as alterações ocorridas no seu corpo, na sua vida. Nega-se a realizar o trabalho da memória que implica em re-elaboração, reapresentação do tempo de forma reatualizada, revivida.

Está paralisada, está congelada, todo o movimento que faz é no sentido de trilhar um caminho coincidente com o passado, todo o movimento é no sentido de retomar o movimento perdido, na forma exata em que era realizado. Na impossibilidade disto, reconstróise por movimentos biônicos. Faz aderir ao seu corpo instrumentos externos que artificialmente "arremedam" movimento.

Porque o futuro está bloqueado, o desejo é suspenso. Não pode continuar sendo mulher ... da forma que era. O futuro daquele passado está interditado.

Esse trabalho de reintegração também está presente na história de Nina. A sua 
temporalidade, além de ser o lugar de expressão e realização do desejo. O corpo também é foco da instalação da deficiência, dessa forma ela refletirá na vivência desse corpo próprio, com a organização perceptual do tempo e dos espaços sociais, e na identidade, conquanto matriz mais geral do desejo do indivíduo.

\subsection{A RUPTURA DA INTEGRALIDADE DO CORPO}

O imbricamento das interpretações da deficiência, construídas pelos sujeitos, que na face do social ou do individual, ou ainda, na extensão dos espaços objetivos e também na profundidade da vivência subjetiva, dá-se nesse recinto que é o próprio corpo.

A deficiência pode ser significada pelo sujeito como limitação, radicalização, fragmentação ou cisão na vivência do corpo, constituindo-se, conseqüentemente, como um elemento potencial de ruptura na experiência de mediação do sujeito com o mundo.

A idéia de falta, de limitação é recorrente nos discursos dos diversos entrevistados, mas pode ser percebida de maneira mais contundente na história de Márcio. As referências a seu corpo não se dão de forma explícita, mas aparecem vinculadas a um sentido de falta, relacionado às necessidades básicas de sono e alimentação. A lógica da sobrevivência está inscrita na forma com o Márcio que se relaciona com seu corpo e com os outros.

No seu corpo, somente podem ser percebidas as necessidades básicas de sobrevivência e que são atendidas de forma bastante determinada e específica. As capacidades motrizes desse corpo não são apreendidas claramente e, assim, há um engajar-se no movimento alheio, na esperança de que colocando-se na posição de espectador que insinua suas necessidades possa tê-las atendidas por uma iniciativa de outrem que casualmente venha ao encontro daquilo que necessita.

Por outro lado, essa experiência de carência radical é extremamente atenuada na história de Robson, que pode significá-la, não mais exatamente como falta, impossibilidade, mas como limites que, inclusive, podem ser relativizados ou compensados. O corpo aqui não é 
vivido exclusivamente como demanda, mas também como possibilidade de experimentar prazer, um prazer ligado às sensações fisicas. No caso de Robson, esse corpo, instrumento para viver sensações, tem história anterior à deficiência e estava no auge de suas potencialidades quando esta se instalou. Na realidade, a deficiência veio radicalizar a "tarefa" da adolescência de testar os limites e as possibilidades do corpo, no desafio de viver o máximo de sensações. Apesar de acrescentar um pouco mais de dificuldade a essa "tarefa", não significou um rompimento com ela, pelo contrário. Em meios alternativos, por exemplo, como a água, é possível para Robson, diminuir o peso da deficiência e, mergulhando, experimentar grande mobilidade.

Essa ambivalência da vivência corporal como potencialidade e limitação simultâneas é agudizada na história de Nina. Há uma aproximação quase que total da vivência do corpo como realidade imediata, não mediatizada pelo simbólico. Num processo de identificação direta com a idéia de natureza, seu corpo de, mulher, inscrito pela deficiência, é vivido como espaço onde coexistem vida e morte. Nesse corpo "naturalizado" ocorrem processos de gestação, de criação e perpetuação da vida imiscuídos de aspectos ligados à destruição, degeneração e morte. Òs possibilidades corporais, é identificada diretamente a experiência da vida e aos limites, a vivência de fim. A instalação da deficiência, significada na família como morte, interditou o seu desenvolvimento pessoal, impedindo a relativização e o estabelecimento de um certo distanciamento em relação a essas experiências mais primitivas.

O sentido da deficiência como definição da própria história pode ser reencontrado em Edna, embora nesse caso, haja uma história anterior. Um tempo muito maior transcorreu, se comparado com Nina, a ponto, inclusive, de falarmos, mais precisamente, não em interdição, mas em suspensão da história cuja transitoriedade e contingência tem que ser mais provavelmente levantada. Tal como para Nina, houve para Edna uma ruptura em sua vida, que se expressa no corpo por um desligamento e se inscreve na lembrança como um lapso, um esquecimento, se inscreve pela ausência de memória. Nina não se lembra do nome que tinha anteriormente e Edna não "sabe" do acidente, nem pode falar de si antes disso. De formas semelhantes, para Tina e para Edna, o caminho da retomada da própria história passa pela 
reconstrução de si, em um processo de reintegração e re-significação do corpo.

Edna ainda está vivendo a nova condição de seu corpo de forma parcial e como se fosse transitória. A deficiência inaugurou ou re-apresentou, não sabemos, Ò Edna uma experiência de estranhamento de si, de seu corpo e do mundo, marcada no início por uma inconsciência, seguida da constatação das lesões de músculos e ossos. Ò sucessão de perdas e danos corresponde também a hierarquia no processo da reconquista do corpo, na retomada dos sentidos atribuídos a ele que vão se sobrepondo.

Recobrada sua consciência, há o desenrolar de operações de restauração da matéria corporal (ossos e músculos) e a partir daí, a reinstalação da sensibilidade corpórea. Estando de posse novamente do "equipamento básico" para estar no mundo, pode retomar a percepção dos outros e do espaço a sua volta. O próximo passo é recuperar o corpo enquanto instrumento funcional, é (re-)habilitar-se para realizar as tarefas básicas, nos espaços familiares, da casa, e dos espaços sociais. Somente aí há alguma menção ao fato de que se tratam de tarefas femininas. Seu corpo ainda não é resgatado como um corpo feminino e, dessa forma, fica a idéia de um trabalho de reconstrução inacabado, suspenso. Edna está vivendo o conflito entre mover-se em direção ao futuro, no sentido de re-elaborar a re-significar essa experiência, ou concentrar-se no esforço de refazer, repetir o caminho trilhado. Neste último caso, a alternativa que se apresenta é a remontagem de seu corpo biológico, a partir de componentes exteriores, alheios, biônicos, que the darão uma simulação de movimento. No entanto, para isso será preciso manter a dicotomia desse corpo biológico/funcional com o corpo real, negando-o como espaço do feminino, explicitação do erótico, como recinto do desejo.

O significado da deficiência como geradora de ruptura é reencontrado nas entrevistas de Tina, não como um fenômeno que afetou seu corpo globalmente ou na mesma intensidade. Para ela, a deficiência aparece como causadora de paralisias corporais parciais. Dessa forma, tornam-se possíveis intervenções no sentido de corrigir, minorar, por mecanismos de compensação, deslocamentos e transplantes, essas paralisias e deformidades. O seu corpo é vivido como objeto que precisa ser "consertado" a fim de melhorar suas formas, seja funcional 
ou esteticamente. Torna-se, assim, espaço por excelência de uma atuação ortopédica, que traz, por sua vez, como conseqüências, a consideração desse corpo de modo compartimentalizado e fixo, membro a membro, artrodesando, fixando artificialmente, as suas articulações. Desse modo, o movimento, para ser possível, é limitado na sua amplitude, reduzido a alguns padrões que se repetem.

A essa cisão, compartimentalização, transplante e fixação das partes do corpo corresponde uma tradução a nível do desejo que, limitado e fixado no sem caminho, é deslocado e re-colocado infinitamente, em padrões de contínua repetição.

\subsection{ESPESSURA E DENSIDADE NOS ESPAÇOS SOCIAIS}

A relação dos sujeitos com os espaços sociais, tais como as instituições, a família e o trabalho aparecem espontaneamente na formulação de seus discursos. As referências a estes àspectos são indicativas de como eles se colocam nestes lugares.

A maneira como se posicionam nestes espaços guarda íntima relação com determinações culturais e econômicas, entrelaçadas com a vivência do estigma e da marginalização. No entanto, essas referências não podem ser simplesmente reduzidas aos aspectos concretos da malha social. São re-interpretações e re-atualizações dessas vivências oriundas de situações objetivas, que se dão a nível da trama subjetiva de cada história. Desta natureza são as menções freqüentes ao Exterior, ao estrangeiro, ao extra-familiar nas falas dos entrevistados. Esse lugar situado para além dos limites da intimidade dos espaços da vida cotidiana é o espaço onde se projetam e se explicitam as vivências de estranheza e proximidade e as relações de pertença com o mundo.

Para todos os sujeitos, exceto Nina, o exterior, a comunidade é espaço privilegiado, onde a vida transcorre de forma menos limitada em função da existência de recursos materiais, tecnológicos, ou em função de outro nível de organização da sociedade. 
Para Tina e Robson que convivem o cotidiano com uma maior disponibilidade desses mesmos recursos materiais, apesar do exterior constituir-se em superlativo dessas condições, este se coloca mais próximo seja ao nível da fantasia ou da realidade.

Pode ser significado, inclusive, como objeto de trabalho ou mesmo como local de moradia. É possivel ir e vir, viajar, suavizando os limites entre essas duas realidades. Robson, por exemplo, tem explicitamente esse objetivo: transpor a realidade do exterior para a vivência de seu país, de seu local de residência.

Já para Márcio, o exterior, também espaço privilegiado, o é em uma dimensão tão radicalmente oposta à realidade vivida que se estabelece uma distância intransponível. No entanto, a vivência de sentir-se estrangeiro, estranho, também é mencionada dentro dessa mesma realidade, recortada em espaços limitados e limitadores. Aqui, se não totalmente estrangeiro, Márcio é migrante, e dessa forma há sempre um afastamento original que marca sua estada nos espaços. Márcio não é do lugar de onde vive, é de Minas, mas de uma Minas que não pode ser reencontrada, de uma Minas perdida para sempre. É interessante notar que a referência a esse desenraizamento é citada tanto na história de Márcio como na de Nina. A ocorrência da eficiência em uma situação de carência familiar, social, econômica e cultural gera a saída do lugar de origem na busca de outras alternativas.

Parece que para ser possível sobreviver/conviver com a deficiência é preciso alcançar algum nível de acesso a recursos materiais, porque na carência extrema, essa conjugação seria impraticável. e totalmente sem perspectivas. No entanto, objetivamente, essa "migração" não garante o encontro com espaços mais acolhedores e facilitadores desse processo. Esse corte primordial com o lugar de origem irá ocasionar afastamento e isolamento. Nem mesmo os melhores espaços não guardam relação nem preparam para viver a realidade.

De qualquer modo, para todos esses sujeitos, há a idéia de que viver a deficiência seria mais fácil em um espaço exterior, distante, fora daquele em que concretamente é vivida. Para alguns, somente, o exterior é São Paulo, para outros, o espaço turístico da Europa e para outros ainda, a Inglaterra, país idealizado dos reis, rainhas, madrinhas e fadas. 
Numa posição intermediária, Edna fala do exterior não como um espaço total, global, mas sim, como um lugar de onde pode seguir objetos, conhecimento ou tecnologia que poderiam auxiliá-la. Espaço pleno dos recursos que the faltam. Não se trata de projetar uma mudança em direção ao estrangeiro, mas exatamente o contrário, um movimento de trazer de fora coisas que possam levá-la de volta ao que era antes, coisas que suprirão suas falhas corporais. Essa busca tampouco dá-se por um movimento seu de lançar-se ao desconhecido, novo ou idealizado. Trata-se na verdade, de buscar ajuda externa através de relacionamentos anteriores, daqui mesmo. No caso de Edna o continente estrangeiro, estranho é seu próprio corpo, transformado pela deficiência.

A dimensão dessas vivências de alheamento podem ser re-encontradas quando as pessoas falam de suas passagens por instituições.

Todos os sujeitos entrevistados, como de resto, qualquer pessoa que viva em sociedade, passaram por instituições durante suas vidas. Entretanto, o impacto com que foram vivenciadas essas passagens e mesmo o sentido que tiveram variaram grandemente para cada um deles, a ponto de constituírem significados opostos.

A menção às instituições ganha relevância na história de cada sujeito na medida em que há uma vinculação estreita com a deficiência. Quando isso não ocorre como no caso do Robson, a questão fica mais diluída, sem significados mais específicos.

Já para Márcio, as instituições pelas quais passou, tiveram um impacto tão radical para a constituição da sua história que, na realidade, elas são como verdadeiros marcos definidores das "fases" de sua vida.

Foram instituições totais, no sentido desenvolvido por Goffman, na medida em que constituíram-se em espaços estruturadores de sua forma de vida e de sua identidade. Nesses espaços, de fato, se fundam e se conservam a sua condição própria de estagnação e marginalização. Espaços estes localizados sempre aquém ou além da realidade que o comum das pessoas partilham, numa não coincidência estruturante deste campo marginal. As origens do processo de institucionalização se dão a partir da deficiência e da carência social em um 
imbricamento de fatores que se reforçam. No entanto, nas instituições em que há uma "mistura" das pessoas e, portanto, a deficiência é colocada lado a lado com outras características tomadas como justificativas para a institucionalização, a carência social salta como razão primeira da exclusão social, e desnuda-se, então, como fator verdadeiramente determinante do processo primário de marginalização e segregação.

Embora também convivendo com a pobreza, Nina não teve experiências tão radicais de carência, até porque conseguiu permanecer morando com o núcleo familiar. Nesse caso, é esse espaço familiar identificado como gerador de isolamento e segregação, espaços institucionais extra-familiares são apontados como aqueles que seletivamente se abrem ou não a sua participação, estimulando-a ou bloqueando a sua entrada e convivência. Conseqüentemente, sinalizam para uma "luta" para inserir-se socialmente.

Os lugares de moradia onde os efeitos da carência são concretamente vividos é que são significados pelos sujeitos como espaços de segregação, embora seja inegável que a nível familiar, os efeitos dessa privação são qualitativamente diferentes. Há, neste último caso, uma certa individualização do tratamento, das relações, mesmo que o sujeito esteja ocupando o lugar do "negado". Há ai uma maior permeabilidade entre os espaços exteriores e interiores.

A existência de outros espaços de continência, como podem se constituir os relacionamentos familiares, influencia nas ligações estabelecidas pelos sujeitos com as instituições.

Os recursos concretos, materiais e econômicos, inclusive, e os recursos internos, subjetivos, são fundamentais para determinar o grau de distanciamento que o sujeito pode manter com relação às instituições e conseqüentemente para vivenciá-las ou não como espaços totais em que sua vida está submersa ou para utilizá-las como serviços, tal como Tina e, mais diretamente, Edna o fazem. Ambas relacionam as instituições como locais para tratamento e aprendizagem enquanto processos complementares. Tratam-se de serviços que visam à conformação ou ao "ensino" de como ser e conviver/superar a deficiência.

Também, por essa razão, justamente, aparecem como dimensões em que se dá o 
"encontro" com a deficiência em si e nos outros. É o espaço da "descoberta" de outras pessoas deficientes pois, há um espaço anterior, uma história prévia constituida pelas relações familiares onde este outro deficiente achava-se ausente, tido, por isso, como inexistente. Os sentimentos que esta "descoberta" traz à tona irão variar em função de outros elementos da história de vida de cada um deles. A época, tanto quanto as relações vividas no seio familiar, ou seja, se esse contato foi na infância, ou na idade adulta, por exemplo, influenciará em muito no impacto dessas experiências.

O modo como são vividas essas relações pode fazer com que o contato com esse estranho e desconhecido mundo da deficiência fique menos assustador e os espaços mesmos em que isso ocorra, menos ameaçadores. Edna, por exemplo, até porque significa o momento que vive atualmente como sendo quase que um período prolongado de "convalescença", busca na família, de fato, na figura da mãe, alguém que possa dispensar-lhe certos cuidados. A casa da mãe é espaço de refúgio e, exatamente por isso, propicia-lhe que tente, paulatinamnte, experimentar-se em uma nova condição.

Já para Nina, a família é a questão fundamental para sua história, embora e precisamente porque o lugar que imagina ocupar nesse espaço é o da indiferença. É extremamente importante buscar sua ascensão como sujeito, a partir da geração de descendências, a partir deste posicionar-se em outro lugar, no lugar de dona-de-casa, mas de outra casa, constituindo uma outra familia, a sua.

Para Tina, Robson e Márcio, a família não aparece com esse mesmo papel, tão relevante. Há poucas menções aos familiares. Estão presentes, mas suas presenças não re constituem em referências primeiras. No caso de Márcio, obviamente porque houve um desligamento muito precoce, uma desvinculação prematura. É estranho para os familiares e os familiares são estranhos para ele.

Tina e Robson, inseridos em outro universo social e cultural, têm valores de independência pessoal muito intensos, dessa forma, falam da casa mas, enquanto espaço de moradia. A saída dessa casa é saída da dependência dos pais, é objetivo perfeitamente factível e 
claramente delineado, não se relaciona a uma necessidade de formar outra família.

Embora o papel que a família ocupe na vida dos sujeitos seja relevante para compreendermos como se dá a colocação destes em outros espaços sociais, a referência à familia não precisa necessariamente ser primeira, a partir da qual o sujeito possa apoiar, embasar e dar parâmetros à construção de seu discurso, na reelaboração atual da sua história. Nem tampouco é possível enquadrarmos essas relações em esquemas explicativos anteriores pré-estabelecidos de rejeição/superproteção sem simplificarmos por demais o imbricamento de fatores aí atuantes e a diversidade de situações decorrentes. Na ponderação do papel que os relacionamentos familiares desempenham para cada sujeito, há diferenças significativas. Essas diferenças são melhor compreendidas, a partir da reconstrução da matriz que cada indivíduo utiliza para imprimir sua forma de estabelecer vínculos com o mundo.

Os relacionamentos familiares importam menos pelo que expõem, explicitam atualmente do que pelo que impuseram fantasticamente ao início da história de cada indivíduo. A relação imaginária de Tina com a imagem materna pode ter pouco a ver com o seu relacionamento com sua mãe no momento presente mas, de certo, marcou indelevelmente sua vinculação com a idéia de ser mulher.

Essa marca característica que cada sujeito utiliza no processo de vinculação com o mundo irá expressar-se também, logicamente, no campo do trabalho.

Neste campo, tanto a determinação econômica ganha contornos fortes, como também o condicionamento social das "escolhas" profissionais de acordo com o papel sexual dos sujeitos.

O trabalho surge para os entrevistados em situações tão díspares que, na realidade, poderiam ser colocadas em um continuum que vai desde a diluição quase que completa da linha divisória entre o trabalho e a mendicância por um lado, até a possibilidade de realizar escolhas buscando conjugar auto-realização, por em prática ideais e obter prazer, por outro lado.

As atividade de Márcio e Nina representam gradações sutis das 
(im)possibilidades de trabalho oferecidas às pessoas portadoras de deficiência pertencentes às classes desfavorecidas economicamente. Impedidas por toda sorte de fatores como por exemplo, os ligados à limitação de transporte e a não qualificação profissional, restam-lhes trabalhos marginais, frutos da dádiva, em atividades que não deixam claros os limites entre a condição de trabalhador e/ou de pedinte. Ou ainda, e quando muito, em atividades fora do mercado, como é o caso do artesanato. Contudo, mesmo aí, nessa situação extrema, limite e privação, os espaços sociais reservados tradicionalmente aos homens e às mulheres no exercício do trabalho são preservados: Márcio desenvolve suas atividades no espaço público das ruas e Nina dentro de casa, ainda que no seu caso haja uma maior diferenciação e identificação das atividades que realiza como "trabalho", ainda que doméstico. De qualquer forma, um trabalho socialmente desvalorizado, mas com mais características de trabalho.

Já se pensarmos os casos de Márcio e Robson é interessante notar que mesmo na presença de tantos pontos opostos haja ainda um terreno comum entre o trabalho que realizam. Ambos são vendedores, e mais que vendedores de objetos, são vendedores de idéias e do próprio conceito de deficiência. Se Robson procura transmitir e formar um conceito social e mercadológico da pessoa deficiente como um consumidor, Márcio comercializa a deficiência como mercadoria, só que associada a idéias de privação e carência. Nesses pólos opostos Márcio ocupa o lugar de quem precisa ser ajudado e Robson daquele que ajuda. A atividade que Márcio desenvolve é compreendida como imposição dos limites da realidade independente de sua vontade, enquanto que para Robson, as opções the parecem variadas e sempre fruto de um processo de escolha.

Esse leque de escolhas, calcado também, e obviamente, na concretude dos recursos sociais e econômicos de Robson, sofre uma redução importante na história de Tina. Para Tina, as possibilidades não são tão diversificadas assim. na verdade, o que salienta-se aí é uma experiência de ambivalência entre dois campos de trabalho. Um deles é identificado com as prescrições mais tradicionais de profissões femininas: ser professora e outro projetado em um espaço mais relacionado ao mundo masculino: ser advogada. 
O condicionamento do papel feminino tem um peso considerável nesta questão, a ponto, inclusive, de aproximar ideais de sujeitos com condições objetivas de vida tão diferentes como é o caso de Tina e Nina: ambas desejam exercitar ou exercitam o trabalho de professoras. Logicamente que não se apagam diferenças marcantes e fundamentais entre elas, como, por exemplo, o valor atribuído ao trabalho na sua realização pessoal, ou mesmo na presença ou não do trabalho doméstico como uma preocupação. para Tina, o lugar de mulher não passa pelo de dona-de-casa como ocorre com Nina, nem tampouco Nina tem o espaço do trabalho como veículo privilegiado para sua reafirmação como sujeito. Para Tina, o trabalho é espaço de realização pessoal, para Nina, meio de subsistência. Mesmo o sentido particular do desejo de ser professora é diferente para ambas. Ao lado da tradicional prescrição social às mulheres da tarefa de ensinar/educar, o lugar de professora para Tina constitui-se em oportunidade para ocupar lugar assegurado e seguro, firmemente pré-estabelecido, de ser mulher e adulta entre crianças. Já para Nina, implica em movimento, em direção à, em esforço de ascensão e participação, não é um lugar, trata-se de um caminho de integração pessoal e social.

O campo de análise do trabalho é privilegiado para percebermos o tecido tramado pelo desejo costurando as pontas das satisfações das necessidades objetivas e diretas das pessoas, com as pontas das satisfações de necessidades outras não tão objetivas.

O trabalho dá a Márcio a ilusão de encontrar-se assistindo o movimento alheio, a Robson, a oportunidade de reencontrar o ideal da adolescência de transformar a realidade, a Nina, um veículo de participação grupal e a Tina, possibilidades de deslocamento do erotismo e do afeto.

Das múltiplas faces da deficiência, que para Márcio gerou imobilidade e um afastamento original dos lugares que habita, que para Nina inscreveu-lhe na vida a presença da morte, para Edna, marcou-lhe o corpo como continente estrangeiro, para Tina imprimiu-lhe ao desejo um caminho fixo e repetitivo e para Robson reatualiza a cada momento o desafio da adolescência de testar limites, ressalta-se a diversidade das atribuições individuais de sentido e 
das construções sociais de conceitos.

Cada um dos sujeitos traz uma marca própria que é a sua forma peculiar de constituir-se como pessoa a partir das possibilidades sociais e individuais, de recursos internos e externos que estão disponiveis, num projeto permanente de significação e re-significação de si mesmos e da deficiência. São, pois, a imagem viva da diversidade e da individualidade dos conceitos, unificados e categorizados quando se passa da profundidade da vivência subjetiva para a extensibilidade dos espaços sociais. 
MARIA, MARIA

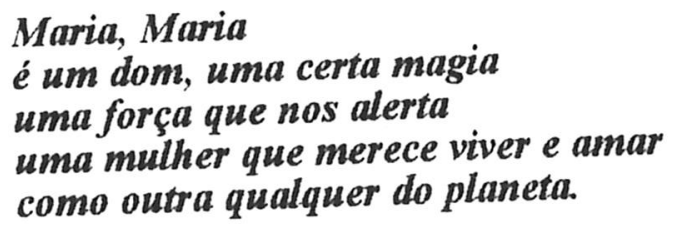

Maria, Maria

é um dom, é a cor, é o suor

é a dose mais forte e lenta

de uma gente que ri quando deve chorar e não vive, apenas agüenta.

Mas é preciso ter força

é preciso ter raça

é preciso ter gana, sempre.

Quem traz no corpo a marca

Maria, Maria

mistura a dor e a alegria.

Mas é preciso ter manha

é preciso ter graça

é preciso ter sonho, sempre

Quem traz na pele essa marca

possui a estranha mania

de ter fé na vida.

Milton Nascimento 
ENTRE O FEMININO E A DEFICIÊNCIA: APROXIMAÇÕES

As idas e vindas desta investigação, no seu movimento de compreender desde os extensos espaços sociais à profundidade da vida intrapsiquica, fizeram com que a cada instante, emergisse uma determinada forma de olhar a experiência de ser mulher deficiente. Na verdade, é como se a cada dimensão desse fenômeno, um instrumento de análise se mostrasse mais adequado, à sua compreensão. Do mesmo modo que a cada diferente mirada, sob determinada perspectiva, fossem realçadas certas faces e contornos do mesmo objeto, sem que fosse possivel dizer que a anterior estava distorcida. O olhar é sempre parcial, o que não significa equivocado. Dessa forma, as relações possíveis de serem estabelecidas entre feminilidade e deficiência dependerão justamente das perspectivas de análise que foram tomadas a cada momento. Assim, se partirmos do entendimento da condição de mulher e de deficiente como situações de prescrição/assunção de papéis, socialmente desvalorizados, poderemos falar de uma relação de sobredeterminação entre estes fenômenos. Relação esta apoiada na existência do estigma e também em razões econômicas.

Ser pobre, deficiente e mulher são condições sociais que, associadas, consolidam e reforçam a experiência de desvalorização pessoal e discriminação social. Esta sobredeterminação é tão mais evidente quanto mais nos aproximamos dos espaços 
tradicionalmente significados pela cultura como espaços masculinos; os espaços públicos das instituições e do trabalho. Neste dominio, a determinação econômica é mais explícita e aí também, e por isso mesmo, as condições de deficiente e de mulher pesam ainda mais como geradoras/agravantes da dependência, segregação e marginalização social.

É importante que se diga que parece que a deficiência tem um peso maior nesta resultante, enquanto situação que apresenta limitações mais concretas à inserção nos mecanismos sociais de produção.

Contudo, é interessante notar que não existe uma representação social singular de mulher deficiente, principalmente se nos afastarmos da questão específica da marginalização social. Nas abordagens psicodinâmicas é o conceito de identidade que faz a articulação entre as dimensões sociais, culturais e individuais.

Neste sentido, se considerarmos o processo de estruturação de suas identidades, a condição de deficiente surge como mais pregnante, tanto social como individualmente, para essas mulheres, e mesmo para os homens, entrevistados.

Não obstante, ainda que a deficiência possa ser identificada como um elemento determinante na estruturação da identidade, o sentido a ela atribuído dependerá do arranjo, num dado momento, do conjunto dos atributos individuais. Desse modo, a representação de mulher deficiente não surge mais como uma situação de soma das valorações negativas entre deficiência e feminilidade, simplesmente, mas: $\mathrm{n}$, como fruto de infinitas outras possíveis relações entre esses dois aspectos dos indivíduos.

Pois, há diferentes formas de "expressar-se" mulher, tais como mãe, amante, esposa, santa, bruxa, "liberada", sendo que todas estas imagens podem ser afetadas e afetar a forma de "expressar" a deficiência.

A maternidade pode constituir-se em uma experiência que concorre para minorar o impacto de sentimentos de desvalorização e de morte, eventualmente, associados à vivência da deficiência. Como também a deficiência pode ser um elemento obstaculizador das expressões diversas da feminilidade, ou seja, pode constituir-se em obstáculo à vivência direta 
das expressões mais tradicionais de mulher como as de esposa e mãe, restando somente a expressão "alternativa" de amante como possibilidade de viver a experiência feminina. Em um caso, a afirmação da feminilidade traz um movimento de inserção social e, em outro, a deficiência limita a diversidade da expressão de ser mulher.

Contudo, resta indagar se, a nível exclusivo das representações sociais de mulher e de deficiente, enquanto conjunto de idéias transmitidas culturalmente, existem correlações. Penso que tal questão só poderia ser respondida globalmente por um outro trabalho que rastreasse a existência de elementos semelhantes ou opostos no conjunto dessas idéias, bem como os contextos e razões de sua constituição dentro do processo histórico. No entanto, alguns aspectos ligados à vivência do corpo podem ser aqui destacados, na medida em que é possível depreendê-los dos relatos dos sujeitos.

A vivência do corpo deficiente como "fragilizado", por um lado, é consonante com a idéia do corpo frágil da mulher, reforçando duplamente o papel de infantilização atribuído tanto à condição de mulher como à de deficiente. Por outro lado, a deficiência é identificada como elemento que "estraga" e adoece o corpo, portanto, impedindo a livre e plena expressão da natureza feminina.

Há "feridas" tanto no corpo deficiente como no corpo feminino, entretanto, no primeiro caso, estas são elementos de degeneração e exclusão, enquanto que no segundo, são aspectos que expõem e intensificam as sensações, fragilizando esse corpo sem negá-lo.

Essas vivências corporais fornecem também indícios importantes para compreendermos, ao menos parcialmente, as diferenças das experiências entre homens e mulheres deficientes. Nos discursos dos homens aqui transcritos, a condição masculina é vivida em extremos. Ou ela não se explicita porque o indivíduo vive situações muito radicais de privação, ou ela aparece como pouco alterada pela deficiência. Na verdade, neste último caso, o sujeito fala de si, sem trazer à tona nenhuma questão sobre sua masculinidade nos espaços públicos do trabalho, por exemplo, e fala pouco da "diferença" vivida em termos da expressão de sua sexualidade. 
Contrariamente, a condição de mulher é problematizada explicitamente na maioria dos relatos.

Além das questões óbvias de que o surgimento deste tema pode ter sido facilitado em um caso e dificultado em outro (pelo fato de a entrevistadora ser uma mulher deficiente) e, de que, culturalmente, as mulheres estão mais ligadas a aspectos subjetivos, às vezes, sendo identificadas com o próprio atributo da pura subjetividade, é inegável que parece que a questão da masculinidade é afetada diferentemente pela deficiência.

A rigor, a condição masculina não aparece como uma condição, uma situação outra à de ser mulher. Como aponta Simone de Beauvoir o Homem se coloca como essencial, ele é. Absoluto, torna-se a-temporal, a-histórico. Se há diferentes formas de viver e expressar a condição feminina, isto não ocorre com o homem que é definido como um conjunto único de atributos positivos.

Assim, a deficiência não pode levar a outros caminhos diferentes da expressão social e esperada - da masculinidade.

A deficiência não é atributo que negue a masculinidade. Desta forma, parece que os homens deficientes podem estar em desvantagem mas não deixam de ser considerados homens, podem ser meio-homens, mas nunca não-homens. A primeira situação é ligada à perda ou diminuição da potência e virilidade que, de qualquer modo, implica em diminuição, mas não, em alteração da condição de ser masculino.

No caso de homens, a deficiência afeta o desempenho sexual somente em alguns casos e, ainda nestes casos, parece que a separação existente no funcionamento masculino, operada pela cultura, entre o mundo público e privado, preserva o sentimento de masculinidade na esfera pública.

Quando a expressão da masculinidade é afetada totalmente, parece que o é em condições extremas de carência psicossocial, onde, até a idéia da própria condição humana está em xeque.

Já para as mulheres, a feminilidade é atributo aderente, circunstancial que pode 
ou não explicitar-se, e, se assim ocorrer. pode sê-lo de diferentes formas. Pode-se ser mais ou menos mulher.

E, embora não exista perda objetiva no desempenho sexual, a deficiencia afeta a identidade globalmente. É possivel não se considerar mulher ou duvidar, colocar em questão, a própria feminilidade. A feminilidade seria assim um atributo a ser explicitado, uma condição potencial.

É conhecido, através de inúmeros trabalhos, que a sexualidade é vivida diferentemente por homens e mulheres.

O corpo feminino é total e difusamente erotizado. O homem, contrariamente, aprende desde cedo a localizá-la em seu órgão genital e, simultaneamente, a realizar uma rígida demarcação/cisão entre sentimento e razão, valorizando mais a última.

Portanto, a deficiência, dentro de uma visão da identidade enquanto estrutura, afetará os homens de forma pontual e "concentrada" e as mulheres, tão extensiva e "difusamente" quanto a expressão extensiva de sua sexualidade.

Uma imagem ligada à alteração de uma solução química poderia ilustrar tais diferenças. É como se a deficiência, no caso dos homens, diminuísse a quantidade de uma solução pelo esvaziamento do líquido, e, no caso das mulheres, a alterasse por diluição.

Contudo, essas considerações devem ser relativizadas, não só porque se baseiam na experiência limitada com esses sujeitos entrevistados, mas, também, porque ao nos aproximarmos mais da trama de cada discurso, e dos múltiplos sentidos alí ocultos explicitados, percebemos que, na especificidade do individuo, há tantas diferenças quantas histórias de vida forem ouvidas e registradas.

Na verdade, no âmbito de cada sujeito, não há tampouco um único sentido para a experiência da feminilidade nem para a da deficiência. Nem mesmo, se pode falar em sentidos diferentes que se sucedem temporalmente. Com um instrumento psicanalítico, ainda que não o tenha usado em sua radicalidade neste estudo, percebe-se que, diferentemente do indicado pelas abordagens psicodinâmicas estruturalistas, sentidos diversos, até opostos, coexistem 
simultaneamente a nível da vida intrapsíquica dos sujeitos.

Estes sentidos, alguns apontados nas análises das entrevistas, são atribuidos de modo dinâmico e dialético pela matriz do desejo que "marca", significa simultaneamente as suas vivências de deficiente e de mulher, bem como, suas inter-relações. 
A porta da verdade estava aberta, mas só deixava passar meia pessoa de cada vez.

Assim náo era posstivel atingir toda a verdade, Porque a meia pessoa que entrava só trazia o perfil de meia verdade. E sua segunda metade voltava igualmente com meio perfil. $E$ os meios perfis não coincidiam.

Arrebentaram a porta. Derrubaram a porta. Chegaram ao lugar luminoso onde a verdade esplendia seus fogos.

Era dividida em metades diferentes uma da outra.

Chegou-se a discutir qual a metade mais bela. Nenhuma das duas era totalmente bela. E carecia optar. Cada um optou conforme seu capricho, sua ilusão, sua miopia.

Carlos Drummond de Andrade 
DA CONCLUSÃO COMO CONVTTE AO (RE)-INÍCIO

E agora, José? E agora, Maria? Qual ou quais as saidas? Há alguma saída para situações que limitam sobremaneira a realização do desejo, condição intrínseca à experiência humana?

Creio que sim, até porque, no limite individual do relato das histórias aqui transcritas, aparece a resistência dos sujeitos à "indiferença ou indiferenciação" social e eles, cada qual a sua maneira, dentro de certas possibilidades, estão vivendo/expressando sua forma peculiar de ser homens ou mulheres.

Ò desvalorização social, às vezes explícita, às vezes sutil, pode-se opor a construção de histórias de vidas alternativas, não totalmente coadunadas às prescritas pela norma.

$\dot{E}$ inegável que a possibilidade dessa construção está grandemente apoiada na realidade material que the dá suporte. Em alguns casos, só é possível sobreviver. Conforme afirma Fábio HERRMANN (1991), há duas situações que igualmente não permitem a expressão do desejo: quando este é completamente satisfeito ou quando se está diante de total impossibilidade de satisfazê-lo. O que permite o movimento do desejo é um certo "diálogo desencontrado" com o mundo, mas um diálogo, em que é possivel a busca simultânea da 
transformação pessoal e da realidade circundante. Condições extremas de carência limitam até satisfações substitutivas.

A alteração das situações objetivas de vida das pessoas deficientes é condição necessária para tal, sendo uma tarefa que pode e deve ser realizada coletivamente.

Não obstante, também é igualmente verdadeiro que somente isto, por certo, não mudará totalmente a complexa questão da realização pessoal, incluindo a ampliação das possibilidades de viver relacionamentos afetivos satisfatórios.

A realidade objetiva exterior é somente uma das condicionantes da forma de expressão do desejo e, na verdade, também é, ela mesma, alterada/reinterpretada por essa forma de expressão.

Se tomarmos, ainda, a realidade das relações, das possibilidades de vínculos que se estabelecem entre as pessoas, e como isto também é o resultado possível da articulação de elementos subjetivos e objetivos, teremos que a definição das possibilidades deste diálogo com o mundo é, de fato, uma operação bastante complexa, não passível de explicações causais. $O$ caminho encontrado pelo desejo para manifestar-se é, em tese, o que possibilitou o "melhor" encontro possivel em um dado momento, entre as demandas pulsionais e os limites/possibilidades da realidade e, por isso mesmo, tende a repetir-se (HERRMANN, 1991).

Então, qual a possibilidade do desejo se realizar contra a tendência conservadora, contra os "a priori" individuais e sociais?

Felizmente, a realidade se apresenta transformada, quer pela alteração objetiva de sua configuração, quer pela representação que dela o próprio sujeito faz, a partir de um diálogo interior, ou através de encontros com outros que a signifiquem diferentemente. A ampliação da capacidade de atribuir sucessiva, mas, principalmente, simultaneamente, significados à realidade (isto é, a possibilidade de auto-representar-se de diferentes maneiras, em um todo articulado, de poder atualizar/transformar as potencialidades da identidade e, conseqüentemente, da realidade), é o que garante a pesquisa de outros caminhos do desejo, talvez mais eficazes, no sentido da obtenção do prazer. Para tanto, é necessária uma ligação 
estreita, um diálogo com o mundo, um sentido de pertença e de imanência, que, por sua vez, garante, respectivamente, a potencialidde de transformação e a idéia de ser o mesmo através das mudanças.

A deficiência, quando significada como ruptura da integralidade do corpo, é subjetivamente vivida com alterações da percepção da temporalidade, gera interrupções ou bloqueios do fluxo da história. É inscrita e lida nos espaços sociais como um lugar estrangeiro. Desta forma, há aqui grandes dificuldades de efetivar esse trabalho de construção de liames internos e externos.

Para sair deste lugar de estranhamento é preciso que haja uma redescoberta e uma recontextualização das diferenças e igualdades e, principalmente, tomá-las como aspectos dinâmicos que se alternam em diferentes momentos e, às vezes, de um mesmo instante, quer no âmbito individual e/ou cultural.

De certa forma, creio que os movimentos reivindicatórios das pessoas com deficiência - quer organizadas em associações, quer individualmente -, na luta pelo respeito a seus direitos de cidadania, contribuem para tal. Não só pela busca das mudanças concretas na qualidade de vida destas pessoas (que de resto já afirmei ser necessária e importante), mas, também, por abrir possibilidades de se auto-representarem e serem representadas de maneiras diversas na medida em que se inserem e atuam de formas outras que as visões estereotipadas que se tem sobre elas.

Evidenciar diferenças entre as pessoas deficientes, e apontar a natureza social e histórica da instituição dos "conceitos" de pessoa deficiente; considerar tais "conceitos" sob diferentes linhas de pensamento teórico, tomando seus recortes e limites de entendimento; questionar se a sobredeterminação entre a condição de mulher e deficiente, quanto à marginalização social, é a única relação possível entre essas características, estas, parece-me, são também intervenções necessárias para se obter a maleabilidade das representações sobre estes aspectos.

Acredito que a ampliação das possibilidades das pessoas deficientes se 
realizarem, passa pelo estabelecimento de outras "crenças" a seu respeito, por parte de individuos concretos com quem se encontrarão no cotidiano e não, pela mera substituição dos discursos sociais.

Aqui, crença é entendida como sustentáculo e elemento de adequação da realidade e identidade, que prescinde de manifestações explícitas e "passeatas", que se faz presente naturalmente na relação do sujeito com o mundo. "Crer em uma cadeira é sentar-se nela, crer no ar é respirar, ..." (HERRMANN, 1991, p.129). Ação e crença confluem-se assim em uma síntese indissociável e "natural".

Realizar-se mulher deficiente é viver tais condições plenamente inclusive pelo desvelamento de seus sentidos ocultos e pela atualização de seus sentidos potenciais.

O primeiro passo é duvidar do sentido imediato. É, de volta ao começo, questionar-se sobre o que é pessoa deficiente, o que é ser mulher, como é ser mulher deficiente. e, a partir das histórias de vida de outros, ouvir e reencontrar respostas. Porém, é preciso estar aberto e preparado para perceber que se tratam de respostas múltiplas e, ainda, não conhecidas, não previsíveis. É lançar-se na mais humana das aventuras, dar um sentido próprio para as coisas e para si mesmo. É (re)-construir o eixo da própria história. 


\section{REFERÊNCIAS BIBLIOGRÁFIAS}

ALVES, Branca Moreira; PITANGUY, Jaqueline. O que é feminismo. 5. ed. São Paulo, Brasiliense, 1985. 74p.

BEAUVOIR, Simone de. O segundo sexo: fatos e mitos. Trad. de Sergio Milliet. Rio de Janeiro, Nova Fronteira, 1980. 500p.

CHAUõ, Marilena de Souza. Cultura e democracia: o discurso competente e outras falas. São Paulo, Moderna, 1981, 220p.

Da realidade sem mistérios ao mistério do mundo: Espinosa, Voltaire, Merleau-Ponty. 2. ed. São Paulo, Brasiliense, 1981, 279p.

1984. 231p.

Repressão sexual, essa nossa (des)conhecida. São Paulo, Brasiliense,

ERIKSON, Erik H. Identidade, juventude e crise. Rio de Janeiro, Zahar, 1972. 322p.

GOFFMAN, Erving. Estigma: notas sobre a manipulação da identidade deteriorada. Rio de Janeiro, Zahar, 1975. 158p.

HERRMANN, Fábio. A clínica psicanalítica: a arte da interpretação. São Paulo, Brasiliense, 1991. 360p.

LAING, Ronald D. O eu e os outros: o relacionamento interpessoal. 5. ed. Rio de Janeiro, Vozes, 1982. 174p.

LIPP, Marilda Novaes (org.) Sexo para deficientes mentais. São Paulo, Cortez/Autores Associados, 1981. 97p.

MEZAN, Renato. Freud, pensador da cultura. 4. ed. São Paulo, Brasiliense, 1986. 680p.

NALLIN, Araci. A reabilitação em instituições: suas razões e procedimentos - análise de representação no discurso. São Paulo, 1992. 295p. Dissertação (Mestrado). Instituto de 
Psicologia, Universidade de São Paulo.

ORGANIZAÇÃO MUNDIAL DE SAÚDE. Clasificación internacional de deficiencias, discapacidads y minusvalias: manual de clasificación de las consecuencias de las enfermedads. Genebra, Comité de los Expertos, 1980. 207p.

SUPLICY, Marta. Conversando sobre sexo. Rio de Janeiro, Edição da Autora, 1983. 340p.

VIOLANTE, Maria Lúcia Vieira. Representações Sociais da Mulher. Psicologia e Sociedade, v.2, n.8, 1984. Apresentado à 36. Reunião Anual da SBPC, São Paulo, 1984. 
Aiello, Denise; Capkin, Lee \& Catania, Holly. Strategies and techniques for serving the disabled assault victim: a pilot training program for providers and consumer. Sexuality \& Disability, 1983, Vol 6(3-4), 135-144.

Akins, Gail L. \& Sutton, Geoffrey W. Developing independence in menstrual care for a nonverbal severely mentally retarded woman: a desensitization case study. Residential Group Care \& Treatment, 1982, Vol 1(1), 23-28.

Anderson, Frances J. Self-concept and coping in adolescents with a physical disability. Issues in Mental Health Nursing, 1982, Vol 4(4), 257-274.

Anzieu-Premmereur, Christine. Ferenczi et les femmes. Perspectives Psychiatriques (França), 1983, Vol 21(3), 175-178.

Aregger, Othmar. Handicap, marriage, and pregnancy: introductory remarks. Heilpädagogik (Alemanha), 1976, Vol 45(1), 2-3.

Askwith, Joyce. The role of social work in enhancing the sexuality of the physically handicapped. Journal of Social Work \& Human Sexuality, 1983, Vol 1(3), 83-93.

Assoun, Paul-Laurent. C'est donc, la chose, toujours. Nouvelle Revue de Psychanalyse (França), 1984(Spr), No 29, 33-59.

Atkins, Bobbie J. Vocation rehabilitation counseling for women: recommendations for the eighties. Rehabilitation Literature, 1982, Vol 43(7-8), 208-212.

Atkins, Bobbie J. Women and rehabilitation of disabled persons: women as members of special populations in rehabilitatio. Report of the Mary E. Switzer Memorial Seminar, 1982, No 6, 38-46.

Baldwin, Charles H. \& Smith, Richard T. An evaluation of the referral and rehabilitation 
process among the minority handicapped. International Journal of Rehabilitation

Banik. Sambhy N. \& Mendelson, Martin A. Group psychotherapy with a paraplegic group, with an emphasis on specific problems of sexuality. International Journal of Group Psychotherapy, 1978, Vol 28(1), 123-128.

Bauer, Carolyn J. Books can break attitudinal barriers toward the handicapped. School Counselor, Vol 32(4), 302-306, 1985.

Becker, Elle F. Sexuality and the spinal-cord-injured women: an interview. Sexuality \& Disability, Vol 2(4), 278-286, 1979. Bejnarowicz, Janusz. Disabled persons in Poland. Social Science \& Medicine, 1984, Vol
$19(11), 1141-1149$.

Bellwald, Joseph. Handicap, marriage and pregnancy: psychiatric an psychological perspectives. Heilpädagogik (Alemanha), 1976, Vol 45(1), 42-49.

Benefield, Lynn \& Head, David W. Discrimination and disabled women. Journal of Humanistic Education \& Development, 1984, Vol 23(2), 60-68.

Blanc, Pierre-Marie. Le sexualité handicapée. Génitif, 1982, Vol 4(7), 5-8.

Bora, K. Surobhi. The needs of the parents of sick children in a general hospital. Indian Psychological Review, 1985, Vol 29, spec. iss.), 18-23.

Brantlinger, Ellen A. Mildly mentally retarded secondary students' information about and attitudes toward sexuality and sexuality education. Education \& Training of the Mentally Retarded, 1985, Vol 20(2), 99-108.

Brindley, G. S. Electroejaculation and the fertility of paraplegic men. Sexuality \& Disability, 1980, Vol 3(3), 223-229.

Brown, Hilary. Sexual knowledge and education of ESN students in centers of further education. Sexuality \& Disability, 1980, Vol 3(3), 215-220.

Buckwalter, Kathleen C.; Wernimont, Theodore \& Buckwalter, Joseph A. Musculo-skeletal conditions and sexuality: II. Sexuality \& Disability, 1982, Vol 5(4), 195-207.

Byrd, E. Keith. Irrational ideas in the management of time. Journal of Applied Rehabilitation Counselling, 1980, Vol 11(1), 46-49. Byrd, E. Keith \& Elliott, Timothy R. Feature films and disability: a descriptive study.
Rehabilitation Psychology, 1985, Vol 30(1), 47-51.

Canton-Dutari, Alejandro. Penile resensitization through biofeedback training: a four-year follow-up. Behavioral Engineering, 1985, Vol 9(2), 66-68.

Carrick, Martha M. \& Bibb, Tamara. Women and rehabilitation of disabled persons: disabled women and access to benefits and services. Report of the Mary E. Switzer Memorial Seminar, 1982, No 6, 28-35.

Carruthers, Barry. Value of AIH/AID to the physically handicapped. Sexuality \& Disability, 
1980, Vol 3(3), 230-231.

Chubon, Robert A. Development and evaluation of a sexuality and disability course for the helping professions. Sexuality \& Disability, 1981, Vol 4(1), 3-14.

Cloerker, Günther \& Neubert, Dieter. Cross-cultural and historical variations of the social reaction towards disabled persons. International Journal of Rehabilitation Research. 1984, Vol 7(3).

Coleman, J. Michael. Self-concept and the mildly handicapped: the role of social comparisons. Journal of Special Education, 1983, Vol 17(1), 37-45.

Cornelissen, G. J. \& McDougall, D. D. The discrepancy between handicapped and being human. International Journal for Advancement of Counselling, 1985, Vol 8(3), 183189.

Crewe, N. M. The psychologist's role in sexual rehabilitation of people with physical disabilities. Sexuality \& Disability, 1979, Vol 2(1), 16-22.

Craft, Ann \& Craft, Michael J. Sexuality and mental handicap: a review. British Journal of Psychiatry, 1981, Vol 139), 494-505.

Cummings, Victor. The role of the physiatrist in managing the sexual problems of disabled patients. Sexuality \& Disability, 1979, Vol 2(1), 5-7.

Dale, Francis. The body as bondage: work with two children with physical handicap. Journal of Child Psychotherapy, 1983, Vol 9(1), 33-45.

Danek, Marita M. \& Lawrence, Richard E. Women in rehabilitation: an analysis of state agency services to disabled women. Journal of applied rehabilitation counseling, 1985, Vol 16(1), 16-18.

Davidson, Albert \& Venditti, Vincent. Two clients' views. Sexuality \& Disability, 1979, Vol 2(1), 23-27.

Davis, Ken. Disabling definitions: a comment on mullender and ward. British Journal of Social Work, 1986, Vol 16(1), 97.

Diamond, Milton. Sexuality and the handicapped. Rehabilitation Literature, 1974, Vol 35(2), 34-40.

Dickie, R. F. Still crazy after all these years: another look at the question of labeling and noncategorical conceptions of exceptional children. Education \& Treatment of Children, 1982, Vol 5(4), 355-363.

Donaldson, Joy. The visibility and image of handicapped people on television. Exceptional Children, 1981, Vol 47(6), 413-416.

Dubinsky, Alex. The sado-masochistic phantasies of two adolescent boys suffering from congenital physical illnesses. Journal of Child Psychotherapy, 1986, Vol 12(1), 73-85.

Dunn, Michael; Lloyd, E. Elaine \& Phelps, Graham H. Sexual assertiveness in spinal cord injury. Sexuality \& Disability, 1979, Vol 2(4), 293-300. 
Dupras, André. Sexualité et deficiences mentales: l'opinion des bénéficiaires. Génitif, 1982,

Eisenberg, M. G. \& Falconer, J. Current trends in sex education programming for the physically disabled: some guidelines for implementation and evaluation. Sexuality \& Disability, 1978, Vol 1(1), 6-15.

Esibill, Nancy. Sexuality and disability: a model for short term training. Sexuality \& Disability, 1980, Vol 3(2), 79-83.

Evans, Juli. Performance and attitudes of occupational therapists regarding sexual habilitation of pediatric patients. American Journal of Occupational Therapy, 1985, Vol 39(10), 664-670.

Fejes, András. Psychotherapeutische Möglichkeiten bei definitiv Bewegungsgeschädigten. Psychiatrie, Neurologie und medizinische Psychologia (Alemanha), 1985, Vol 37(2), 101-106.

Fekin, Pamela. The definition of disability. British Journal of Occupational Therapy, 1985, Vol 48(4), 106-108.

Fergunson, Kristi \& Figley, Barbara. Sexuality and rheumatic disease: a prospective study. Sexuality \& Disability, 1979, Vol 2(2), 130-138.

Furger, Franz. Marriage and prgnancy: their Christian and ethical problems in the case of physical and mental handicaps. Heilpädagogik (Alemanha), 1976, Vol 45(1), 58-65.

Geiger, Robert C. Neurophysiology of sexual response in spinal cord injury. Sexuality \& Disability, 1979, Vol 2(4), 257-266.

Gillan, Patricia. Psychological methods in sex therapy for the disabled. Sexuality \& Disability, 1980, Vol 3(3), 199-202.

Glatz, Paul F. Corporate social responsibility and services to people with disabilities: Comment. Journal of Rehabilitation Administration, 1986, Vol 10(2), 67-68.

Glueckauf, Robert L. Sex counseling training programs for rehabilitation personnel. Sexuality \& Disability, 1983, Vol 6(2), 106-110.

Gokhale, S. D. Rehabilitation of disabled workers in Asia and Oceania. Indian Journal of Social Work, 1982, Vol 43(1), 27-38. Goldberg, Richard T. Toward an understanding of the rehabilitation of the disabled
adolescent. Rehabilitation Literature, 1981, Vol 42(3-4), 66-74.

Goldsmith, Lois. Sexuality and the physically disabled: the social work role. Sexuality \& Disability, 1979, Vol 2(1), 33-37.

Goodman, R. E. Sex aids and the disabled. Sexuality \& Disability, 1980, Vol 3(3), 232235.

Goodwin, Lloyd R. A holistic perspective for the provision of rehabilitation counseling services. Journal of Applied Rehabilitation Counseling, 1986, Vol 17(2), 29-36. 
Green, Denise T. A human sexuality program for developmentally disabled women in a sheltered workshop setting. Sexuality \& Disability, 1983, Vol 6(1), 20-24.

Grengaard, Carter \& Kristensen, Kirsten. Borna med vidtgáence fysik/psykisk handicap i Nordjyllands amt, fodt 1975-1981. Skolepsylologi, 1983, Vol 20(1), 12-21.

Greenwood, Judith G. Disability dilemmas and rehabilitation tensions: a twentieth century inheritance. Social Science \& Medicine, 1985, Vol 20(12), 1241-1252.

Hahn, Harlan. Reconceptualizing disability: a political science perspective. Special issue:social science perspectives on vocational rehabilitation. Rehabilitation Literature, 1984, Vol $45(11-12), 362-365$.

Hakim-Elahi, E. Contraceptive of choice for disabled (handicapped) person. New York State Journal of Medicine, 1982, Vol 82(11), 1601-1608.

Halstead, Lauro S. \& Halstead, Kris. Disability SARs and small group experience: a conceptual framework. Sexuality \& Disability, 1983, Vol 6(3-4), 183-196.

Hamre-Nietupski, Susan \& Ford, Alison. Sex education and related skills: a series of programs implemented with severely handicapped studentes. Sexuality \& Disability, 1981, Vol 4(3), 179-193.

Harper, Dennis C. Personality characteristics of physically impaired adolescent. Journal of Clinical Psychology, 1978, Vol 34(1), 97-103.

Harrison, Don K. \& Wayne, Barbara. Gender and rehabilitation accessibility. Journal of Rehabilitation Administration, 1986, Vol 10(2), 50-56.

Hartman, Carl; MacIntosh, Barry \& Englehardt, Beverly. The neglected and forgotten sexual partner of the physically disabled. Social Work, 1983, Vol 28(5), 370-374.

Harvey, David H. \& Greenway, A. P. The self-concept of physically handicapped children and their non-handicapped siblings: an empirical investigation. Journal of Child Psychology \& Psychiatry \& Allied Disciplines, 1984, Vol 25(2), 273-284.

Hendrick, Susan S. Spinal cord injury: a special kind of loss. Personnel \& Guidance Journal, 1981, Vol 59, (6), 355-359.

Hepner, Paula J. Sexual expression and the mentally retarded: the lawyer's role. Sexuality \& Disability, 1979, Vol 2(1), 38-46.

Heshusius, Lous. Sexuality, intimacy, and persons we label mentally retarded: what they think - what we think. Mental Retardation, 1982, Vol 20(4), 164-168.

Hicks, Susan. Ralationship and sexual problems of the visually handicapped. Sexuality \& Disability, 1980, Vol 3(3), 165-176.

Higgins, Glenn E. Sexual response in spinal cord injured adults: a review of the literature. Archives of Sexual Behavior, 1979, Vol 8(2), 173-196.

Hingsburger, David \& Griffiths, Dorothy. Dealing with sexuality in a community residential service. Psychiatric Aspexts of Mental Retardation Reviews, 1986, Vol 5(12), 63-67. 
Hoeller, Keith. Merleau-Ponty and psychology: introduction. Review of Existential Psychology \& Psychiatry, 1982-83, Vol 18(1-3), 3-22.

Hoeller, Keith. Phenomenology, psychology, and science: II. Review of Existential Psychology \& Psychiatry, Vol 18(1-3), 143-154.

Hoeller, Keith. Merleau-Ponty bibliography of English translations. Review of Existential Psychology \& Psychiatry, 1982-83, Vol 18(1-3), 257-259.

Hollingsworth, David K. \& Pease, Lesley A. The impact of public assistance on the rehabilitation process of handicapped women. Journal of Applied Rehabilitation Counseling, 1980, Vol 11(4), 192-195.

Hunter, James. Eros and wholeness. Journal of Religion \& Health, 1983, Vol 22(3), 175190.

International bibliographical documentation.

International Journal of Rehabilitation Research, 1984(Dec), Vol 7(3), 347-366.

Johnson, S. S. \& Janes, M. W. Legislation and litigation involving the employment of disabled women: an overview. Personnel \& Guidance Journal, 1984, Vol 62(6), 346-349.

Journal articles on rehabilitation research. International Journal of Rehabilitation Research, 1981(Dec), Vol 4(4), 565-594.

Journal articles on rehabilitation research. International Journal of Rehabilitation Research, 1982, Vol 5(1), 89-118.

Journal articles on rehabilitation research. International Journal of Rehabilitation Research, 1982(Jun), Vol 5(2), 261-279.

Journal articles on rehabilitation research. International Journal of Rehabilitation Research, 1982(Sep), Vol 5(3), 395-420.

Journal articles on rehabilitation research. International Journal of Rehabilitation Research, 1982(Dec), Vol 5(4), 553-567.

Kabler, Michael L. \& Carlton, Glenn R. Educating exceptional students: a comprehensive team aproach. Theory into Practice, 1982(Spr), Vol 21(2), 88-96.

Kaiser, Susan B.; Freeman, Carla M. \& Wingate, Stacy B. Stigmata and negotiated outcomes: management of appearance by persons with physical disabilities. Deviant Behavior, 1985, Vol 6(2, 205-224.

Kaplan, Steven P. Rehabilitation counseling in medical settings: career opportunities. Journal of Applied Rehabilitation Counseling, 1986(Sum), Vol 17(2), 45-46.

Kempton, Winifred. Sex education: a cooperative effort of parent and teacher. Exceptional Children, 1975(May), Vol 41(8), 531-535.

Kiernat, Jean M. Environment: the hidden modality. Physical \& Occupational Therapy in Geriatrics, 1982(Fal), Vol 2(1), 3-12.

Kovacs, George. The personalistic understanding of the body and sexuality in Merleau-Ponty. 
Review of Existential Psychology \& Psychiatry, 1982-83, Vol 18(1-3), 207-217.

Krauskopf, Lutz. Handicap, marriage, and pregnancy: legal perspectives. Heilpädagogik (Germ), 1976(Mar), Vol 45(1), 35-41.

Kriegsman, Kay H. \& Celotta, Beverly. Sexuality in creative coping groups for women with physical disabilities. Sexuality \& Disability, 1981(Fal), Vol 4(3), 169-172.

Kusinitz, Mark. Health professionals work for sexual rights of disabled persons. New York State Journal of Medicine, 1984(Mar), Vol 84(3, Pt 1)), 140-142.

Lacan, Jacques. Merleau-Ponty: in memoriam. Review of Existential Psychology \& Psychiatry, 1982-83, Vol 18(1-3), 73-81.

Larson, Paul C.; Boyle, Edward S. \& Boaz, Melvin E. Relationship of self-concept to age, disability, and institutional residency. Gerontologist, 1984(Aug), Vol 24(4), 401-407.

Lesh, Kay \& Marshall, Catherine. Rehabilitation:focus on disabled women as a special population. Journal of Applied Rehabilitation Counseling, 1984(Spr), Vol 15(1), 18-21.

Levin, David M. Eros and psyche: a reading of Merleau-Ponty. Review of Existential Psychology \& Psychiatry, 1982-83, Vol 18(1-3), 219-239.

Longmore, Paul K. A note on language and the social identity of disabled people. American Behavioral Scientist, 1985(Jan-Feb), Vol 28(3), 419-423.

Lowe, Judith \& Carroll, Douglas. The effects of spinal injury on the intensity of emotional experience. British Journal of Clinical Psychology, 1985(May), Vol 24(2), 135-136.

Luyten, Norbert A. Handicap, marriage, and pregnancy: philosophical and anthropological perspectives. Heilpädagogik (Germ), 1976(Mar), Vol 45(1), 26-35.

McAnarney, Elizabeth R. Social maturation: a challenge for handicapped and chronically ill adolescents. Journal of Adolescent Health Care, 1985(Mar), Vol 6(2), 90-101.

McKown, Janece M. Disabled teenagers: sexual identification \& sexuality counseling. Sexuality \& Disability, Vol 7(1-2), 17-27.

Mercer, Janece; Andrews, Henry \& Mercer, Arthur. Teffects of physical attractiveness and disability on client ratings by helping professionals. Journal of Applied Rehabilitation Counseling, 1983(Win), Vol 14(4), 41-45.

Miller, Susan \& Morgan, Margaret. Marriage matters: for people with disabilities too. Sexuality \& Disability, 1980(Fal), Vol 3(3), 203-211.

Niñarro López, José; Pérez, Vicente S. \& Castaño Linares, Dolores Estudio de la ansiedad en pacientes en hemodiálisis y transplantados. Revista de Psicología General y Aplicada, 1985, Vol 40(20), 318-329.

Montalta, Eduard. Handicap, marriage, and pregnancy from the perspective of remedial education. Heilpädagogik, 1976(Mar), Vol 45(1), 65-73.

Montgrain, Noel. On the vicissitudes of female sexuality: the difficult path from "anatomical destiny" to psychic representation. International Journal of Psycho-Analysis, 1983, Vol 
$64(2), 169-186$.

Nathan, Susan W. Body image of scoliotic female adolescents before and after surgery. Maternal - Child Nursing Journal, 1977(Fal), Vol 6(3), 139-149.

Neff, Jan. Another perspective on sexuality and those who are deaf and blind. Sexuality \& Disability, 1979(Fal), Vol 2(3), 206-210.

Negro, Giovanna. Sexuality in the handicapped: some observations on human needs and attitudes. Rehabilitation Literature, 1975(Jul), Vol 36(7), 202-205.

Neistadt, Maureen E. Sexuality counseling for adults with disabilities: a module for an occupational therapy curriculum. American Journal of Occupational Therapy, 1986(Aug), Vol 40(8), 542-545.

Neistadt, Maureen \& Baker, Maureen F. A program for sex counseling the physically disabled. American Journal of Occupational Therapy, 1978(Nov-Dec), Vol 32(10), 646647.

Niklas, Dariusz. Dependence and stigma in the life of the disabled. Studia Sogologcizne (Poln), 1949-166, Vol 3(62), 1976.

Nordqvist, Inger. Sexual counselling for disabled persons. Sexuality \& Disability, 1980, (Fal), Vol 3(3), 193-198.

Obani, Tim \& Doherty, Jim. The development of concepts of handicap in adolescence: a cross-cultural study II. Educational Studies, 1986, Vol 12(2), 191-212,

Osuji, Oluigbo N. Personality factors in acceptance of loss among the physically disabled. Psychological Record, 1985(Win), Vol 35(1), 23-28.

Ottenbacher, Kenneth. An investigation of self-concept and body image in the mentally retarded. Journal of Clinical Psychology, 1981(Apr), Vol 37(2), 415-418.

Packer, Jaclyn. Sex stereotyping in vocational counseling of blind/visually impaired persons: a national study of counselor choices. Journal of Visual Impairment \& Blindness, 1983(Jun), Vol 77(6), 261-268.

Pasquasy, R. Sexuality and procreation among the profoundly retarded. Bulletin de Psychologie Scolaire er d'Orientation (Fren), 1977(Jul), Vol 26(3), 141.

Patrick, Dean C. Gender and rehabilitation accessibility. Comment. Journal of Rehabilitation Administration, 1986(May), Vol 10(2), 57.

Paxman, John M. Health care for handicapped adolescents: international legislative and policy trends. Journal of Adolescent Health Care, 1982(Sep), Vol 3(2), 103-109.

Peterson, Yen. The empact of physical disability on marital adjustment: a literature review. Family Coordinator, 1979(Jan), Vol 28(1), 47-51.

Philipson, llene. The repression of history and gender: a critical perspective on the feminist sexuality debate. Signs, 1984(Fal), Vol 10(1), 113-118.

Pitceathly, Amanda S. \& Chapman, James W. Sexuality, marriage and parenthoof of mentally 
retarded people. International Journal for the Advancement of Counselling, 1985, Vol 8(3), 173-181.

Popovic, Dragica. Symbolism of eyes and their dysfuntion. Psihijatrija Danas (Srcr), 1984, Vol 16(3-4), 303-308.

Resnick, Michael D.; McGrath, Marianne \& Tenbensel, Robert. Social maturation: work group proceedings. Journal of Adolescent Health Care, 1985(Mar), Vol 6(2), 102-107.

Richards, J. Scott. Sex and arthritis. Sexuality \& Disability, 1980(Sum), Vol 3(2), 97-104.

Richman, Gina S.; Ponticas, Yula; Page, Terry J. \& Epps, Susan. Simulation procedures for teaching independent menstrual care to mentally retarded persons. Applied Research in Mental Retardation, 1986, Vol 7(1), 21-35.

Rivlin, Mark. The disabled gay: an appraisal. Sexuality \& Disability, 1980(Fal), Vol 3(3), 221-222.

Robbins, Kathleen H. Traumatic spinal cord injury \& its impact upon sexuality. Journal of Applied Rehabilitation Counseling, 1985(Spr), Vol 16(1), 24-27.

Robert, Jacques-Michel. Sexualité et conseil génétique. Génitif, 1982, VoL 4(7), 9-16.

Robillard, Kristen \& Fichten, Catherine S. Attributions about about sexuality and romantic involvement of physically disabled college students: an empirical study. Sexuality \& Disability, 1983(Fal-Win), Vol 6(3-4), 197-212.

Rodriguez, Rolando R. Psychological crises of the ill and handicapped. Emotional First Aid: A Journal of Crisis Intervention, 1985(Spr), Vol 2(1), 44-50.

Rohme, Margaret W. The public health nurse as sexual counselor for spinal cord injured men. Sexuality \& Disability, 1979(Spr), Vol 2(1), 8-15.

Romano, Mary D. Sexuality and the disabled female. Sexuality \& Disability, 1978(Spr), Vol 1(1), 27-33.

Rousso, Harilyn. The relationship between physical disability and narcissism: a critique of the literature. Clinical Social Work Journal, 1985(Spr), Vol 13(1), 5-17.

Rüegg. Walter. Handicap, marriage, and pregnancy: sociological an sociopsychological perspectives. Heilpädagogik (Germ), 1976(Mar), Vol 45(1), 49-58.

Sanders, G.L. Relationships of the handicapped: issues of sexuality and marriage. Family Therapy Collections, 1984, Vol 11), 63-74.

Sangprrom, J. El esquema corporal y deficiencia motora. Anuario de Psicologia (Span), 1977, No $16,95-111$.

Saunders, E.J. Staff members' attitudes toward the sexual behabior of mentally retarded residents. American Journal of Mental Deficiency Vol 84(2), 206-208.

Sawyer, H.W; Allen, H.A.; Reisin, B.L. Microcounseling: a counselor training format relating to sexual concerns of spinal cord injured women. Sexuality \& Disability, 1983(Spr), Vol 6(1), 30-37. 
Sawyer, J.W.; Allen, H.A. Sexuality and spinal cord injured individuals: a challenge for counselors and trainers. Journal of Applied Rehabilitation Counseling. 1983(Win), Vol 14(4), 14-17.

Schildmann, Ulrike. Female living conditions and disability. International Journal of Rehabilitation Research, 1984, Vol 7(3), 324-326.

Schneider, Edith. Human sexuality and the handicapped. The Personal and Guidance Journal, 1976, Vol 54(7), 378-380.

Schuler, Mark. Sexual counseling for the spinal cord injured: a review of five programs. Journal of Sex \& Marital Therapy, 1982(Fal), Vol 8(3), 241-252.

Schwarcz, Joseph H. Modes of representating the self-image in the spontaneous paintings of physically handicapped children. Confinia Psychiatrica, 1978, Vol 21(1-3), 140-149.

Selected book publications on rehabilitation and related fields. International Journal of Rehabilitation Research, 1982, Vol 5(1), 119-127.

Selected book publications on rehabilitation and related fields. International Journal of Rehabilitation Research, 1982(Jun), Vol 5(2), 280-288.

Selected book publications on rehabilitation and related fields. International Journal of Rehabilitation Research, 1982(Sep), Vol 5(3), 421-436.

Selected book publications on rehabilitation and related fields. International Journal of Rehabilitation Research, 1982(Dec), Vol 5(4), 568-574.

Selected book publications on rehabilitation and related fields. International Journal of Rehabilitation Research, 1984, Vol 7(3), 367-375.

Selvin, Hanan C. Sexuality among the visually handicapped: a beginning. Sexuality \& Disability, 1979(Fal), Vol 2(3), 192-199.

Sensky, Tom. Family stigma and physical deformity in children. General Hospital Psychiatry, 1985(Oct), Vol 7(4), 385-386.

Sexual experiences with nonhandicapped partners of patients with traumatic spinal cord lesions. Nederlands Tijdschrift voor de Psychologie en haar Grensgebieden (Dutch), 1984(Oct), Vol 39(7), 427-433.

Sherer, Denise P. Broadening horizons: a human sexuality program at summer camp. Sexuality \& Disability, 1980(Sum), Vol 3(2), 105-111.

Sidman, Janice M. Sexual functioning and the physical disabled adult. American Journal of Occupational Therapy, 1977(Feb), Vol 31(2), 81-85.

Silva, John M. \& Klatsky, Jennifer. Body image and physical activity. Physical \& Occupational Therapy in Pediatrics, 1984(Fal), Vol 4(3), 85-92.

Siwek, Stanislaw. Self-acceptance of youth with locomotive disfunctions. Polish Psychological Bulletin, 1983, Vol 14(3-4), 267-271. 
Skord, Kenneth G. \& Schumacher, Brockman. Masculinity as a handicapping condition. Rehabilitation Literature, 1982(Sep-Oct), Vol 43(9-10), 284-289.

Smith, Susan. The link between sexual maturation and "adolescent grieving" in parents of the dependent disabled. Sexuality \& Disability, 1983(Fal-Win), Vol 6(3-4), 150-154.

Snow, Duane. Arthritic sexuality: implications concerned in the rehabilitation and adjustive processes of arthritics. Journal of Applied Rehabilitation Counseling, 1979(Spr), Vol $10(1), 15-19$.

Steger, Jeffrey C. \& Brockway, Jo A. Sexual enhancement in spinal cord injured patients: behavioral group treatment. Sexuality \& Disability, 1980(Sum), Vol 3(2), 84-96.

Stewart, W. F. "Caring and counseling": an historical perspective. Sexuality \& Disability, 1980(Fal), Vol 3(3), 144-149.

Strenta, A. Christopher \& Kleck, Robert E. Physical disability and the attribution dilemma: perceiving the causes of social behavior. Journal of Social \& Clinical Psychology, 1985, Vol 3(2), 129-142.

Task Force on Concerns of Physically Disabled Women. Toward intimacy: family planning and sexuality concerns of physically disabled women. e.2, New York, Human Sciences Press, 1978. p.63.

Tate, Denise G. \& Weston, Nancy H. Women and disabilities: an international perspective. Rehabilitation Literature, 1982(Jul-Aug), Vol 43(7-8), 222-227.

Taylor, Mary E. \& Wolford, Cynthia A. Sexuality and the disabled: apathy on the campus. Journal of American College Health, 1985(Aug), Vol 34(1), 34-36.

Thomas, Susan \& Wolfensberger, Wolf. The importance of social imagery in interpreting societally devalued people to the public. Rehabilitation Literature, 1982(Nov-Dec), Vol 43(11-12), 356-358.

Thorn-Gray, Beverly E. \& Kern, Leslie H. Sexual dysfuntion associated with physical disability: a treatment guide for the rehabilitation practitioner. Rehabilitation Literature, 1983(May-Jun), Vol 44(5-6), 138-144.

Thornton, Carla E. A nurse-educator in sex and disability. Sexuality \& Disability, 1979(Spr), Vol 2(1), 28-32.

Thurer, Shari L. Women and rehabilitation. Rehabilitation Literature, 1982(Jul-Aug), Vol 43(7-8), 194-197.

Tripp, Amy W. \& Kahn, James V. Comparison of the sexual knowledge of hearing impaired and hearing adults. Journal of Rehabilitation of the Deaf, 1986(Jan-Feb), Vol 19(3-4), 15-18.

Tychey, C. Handicap moteur et identification au rôle sexuel: approche différentielle. Revue de Psychologie Appliquée, 1981, Vol 31(4 spec iss), 437-461.

Uelmen, Jean. The relationship of selected variants and body-image for physically handicapped persons. Dissertation Abstracts International, 1978(Nov), Vol 39(5-A), 2812. 
Valles, Gérar. Attitude des parents face à la sexualité et l'education sexuelle des debiles mentaux. Génitif (Fren), 1982, Vol 4(9), 24-32), 170.

Vanier, Jean. The quest for human sexuality. Génitif (Fren), 1982, Vol 4(8), 2-7.

Vargo, J. W. The disabled wife and mother: suggested goals for family counselling. Canadian Counsellor, 1979(Jan), Vol 13(2), 108-111.

Vash, Carolyn L. Employment issues for women with disabilities. Rehabilitation Literature, 1982(Jul-Aug), Vol 43(7-8), 198-207.

Vash, Carolyn L. Women and employment: women and rehabilitation of disabled persons. Report of the Mary E. Switzer Memorial Seminar, 1982, No 6, 15-24.

Vinick, Barbara H. Difficult task: caring for an invalid wife. Medical Aspects of Human Sexuality, 1986(May), Vol 20(5), 141-145.

Viossat, P. \& Desbrus, L. Reflexion sur la sexualité des adultes handicapés. Génitif, 1982 (Fren), Vol 4(9), 15.

Wallace, Douglas. Sexuality and the disabled: implications for the sex education of medical students. Sexuality \& Disability, 1980(Spr), Vol 3(1), 17-25.

Ward-McKinlay, Thomas; Botvinn-Madorsky, Julie G. \& Ward-McKinlay, Candace. Sexuality and disability. Family Therapy Collections, 1983, No 5, 129-152.

Warnemuende, Robert. Misconceptions and attitudes about disability and the need for awareness. Journal of Applied Rehabilitation Counseling, 1986(Spr), Vol 17(1), 50-51.

Wertlieb, Ellen C. Minority group status of the disabled. Human Relations, 1983(Nov), Vol 38(11), 1047-1063.

Wilburn, Margaret M. Recreation and sexuality for handicapped and geriatric patients in a long term care hospital. Sexuality \& Disability, 1979(Spr), Vol 2(1), 77-78.

Williamson-Ige, Dorothy K. \& McKitric, Eloise J. An analysis of sex differences in educating the handicapped. Journal of Research \& Development in Education, 1985(Sum), Vol 18(4), 72-78.

Willmuth, Mary E. Sexuality after spinal cord injury: a critical review. Clinical Psychology Review, 1987, Vol 7(4), 389-412.

Wong, Daniel W. "Gender and rehabilitation accessibility". Comment. Journal of Rehabilitation Administration, 1986(May), Vol 10(2), 57-58.

Zwerner, Janna. A study of issues in sexuality counseling for women with spinal cord injuries. Women \& Therapy, 1982(Fal), Vol 1(3), 91-100. 